\title{
14. VOLCANIC ROCKS CORED IN THE CENTRAL PACIFIC, LEG 17, DEEP SEA DRILLING PROJECT ${ }^{1}$
}

Manual N. Bass and Ralph Moberly, Hawaii Institute of Geophysics, Honolulu, Hawaii J. Michael Rhodes, Lockheed Electronics Corp., 16811 El Camino Real, Houston, Texas

Chi-yu Shih, The Lunar Science Institute, 3303 NASA Road 1, Houston, Texas

and

Stanley E. Church, Geochemistry Branch, NASA Manned Spacecraft Center, Houston, Texas

\begin{abstract}
A variety of fresh to highly altered igneous rocks and sediments with minor to abundant volcanic components was cored at seven sites during Leg 17. Diagenetic alteration of the igneous rocks is ubiquitous and is particularly intense at Sites 167,170 , and 171. Zeolite facies metamorphism affected the lowest rocks at Hole $165 \mathrm{~A}$. Diagenesis is slow in the absence of high $\mathrm{CO}_{2}$ activity. However, in a $\mathrm{CO}_{2}$-rich environment it leads to rapid replacement of olivine, glass, and mesostasis, and slow replacement of pyroxene by montmorillonite. Plagioclase is only slightly to moderately attacked in the $\mathrm{CO}_{2}$-rich environment and calcium is lost from pyroxene. Sodium, potassium, and water are gained in the montmorillonite, and iron is oxidized to the extent that available oxygen permits.

The best methods of deriving original rock and magma types of altered specimens are through "refractory" (i.e., alterationresistant) trace elements, but even these appear to be lost when alteration is so intense that pyroxene is destroyed, such as at Sites 167, 170, and 171. Taking all available data into account, the following conclusions are drawn.

True basement (ocean ridge basalts of Layer 2 of the oceanic crust, accreted at a spreading center) was cored at Sites 164 and 166 and possibly at the bottom of the hole at Site 169. At all other sites and higher in the hole at Site 169, igneous rocks were recovered that are more alkaline than ocean ridge basalts. They probably were emplaced at a distance from a spreading center above a section of older sediments and do not represent true basement. The evidence for this is conclusive at Site 169, where a sill of uncertain petrologic affinities was penetrated, and is very strong at Sites 167 and 171, which are located on large seamounts (Magellan Rise and Horizon Guyot, respectively). The evidence is weaker, but persuasive, at Site $165 \mathrm{~A}$ and Site 170. Sills were definitely (Site 169) or probably (Sites 167 and 170) cored at three sites, and seem to be a common mode of emplacement when the true basement is covered by unconsolidated sediments.

In addition to flows and sills, volcanic material appears in the sedimentary section as turbidites, hyaloclastites, pyroclastites, and dispersed detritus in pelagic sediments. Like the relatively alkaline rocks discussed above, the volcanic components in the sediments record activity that postdates the time of accretion of the underlying crustal plate at a spreading center. In general, the volcanic sediments were derived from nearby seamounts and ridges which yielded rubble and turbidites not only by slumping of unstable slopes but also by explosive activity as peaks approached sea level. Where the peaks emerged as islands, as at Site 171, subaerially eroded detritus and perhaps forereef calcarenites and calcirudites also were supplied.
\end{abstract}

\footnotetext{
${ }^{1}$ Hawaii Institute of Geophysics Contribution No. 545.
} 


\begin{abstract}
Most sills and flows emplaced far from spreading centers probably occur near volcanic seamounts and ridges. Nonetheless, some evidence suggests that the correlation is not absolute. It remains for future legs of the Deep Sea Drilling Project to determine how widespread such bodies are in regions of flat ocean floor. Granting their occurrence, how "leaky" is the oceanic lithosphere and by what conduits other than linear fractures do they ascend?
\end{abstract}

\section{INTRODUCTION}

This chapter presents an extended account of the petrography and petrochemistry of igneous rocks recovered on Leg 17 as well as a summary of volcanic components in the sediments overlying, and in some cases interbedded with, the igneous rocks. First, the analytical methods are described. This is followed by a brief interpretation of conclusions which can be drawn from the chemical and isotopic data, and then the petrography is given. The petrography for each site consists of a general description of the igneous and volcaniclastic rocks and detailed petrography (see Appendix B). The general description includes subjective comments which bear on conclusions drawn elsewhere in this volume and, in cases where the data bear cogently on broad problems of deep-sea petrology (most notably the data for Hole 165A and Site 170), comments on those problems. The general description is followed by detailed petrography based on studies with both the petrographic and binocular microscopes. Much of the detailed petrography is presented in the form of notes on the individual components distinguished during comprehensive modal analyses (more than 2000 point counts in all cases and more than 3000 in most).

Many of the data are summarized in Appendix A and Tables 1-7 as follows: X-ray mineralogy (Appendix A); major and minor element chemistry by X-ray fluorescence (Table 1); molecular norms (Table 2); trace element chemistry by isotope dilution (Table 3); isotopic data on $\mathrm{Sr}, \mathrm{Pb}, \mathrm{U}$, and Th (Table 4); a separate summary of X-ray data on opaque minerals from Appendix A (Table 5); a separate summary of X-ray data on calcite compositions from Appendix A (Table 6); and a comparison of S values by two analytical methods (Table 7 ).

This chapter is, therefore, a presentation of new data and some speculations based on those data. Few references to published petrologic studies are cited; any documented account of the igneous rocks from Leg 17 will follow at a later date.

The main part of this report was prepared by Bass. He is responsible for the igneous petrography, including a reexamination of Moberly's shipboard slides, and the X-ray mineralogy (Appendix A and Tables 5 and 6). Moberly is responsible for the description of the volcanic sedimentary rocks and for assembling Bass' notes. They are jointly responsible for editing the chapter. Rhodes analyzed for major and trace elements by X-ray fluorescence methods (Table 1, Appendix B). Rare earth element (REE), Ba concentrations (Table 3), and $\mathrm{Sr}$ isotopic compositions (Table 4) were measured by Shih. The concentrations of $\mathrm{Pb}, \mathrm{U}$, and Th (Table 3) and their isotopic relationships (Table 4) were determined by Church. Special thanks are extended to R. L. Armstrong for a K-Ar age on a K-feldspar concentrate from Site 169; to E. K. Gibson, Jr., for the $\mathrm{CO}_{2}$ data (Table 1); and to Gibson and R. B. Wilkin for the $\mathrm{S}$ analyses by the LECO automatic sulfur determinator (Table 7).

Church's research, and part of that by Bass, were performed during their tenures as National Research Council Resident Research Associates at the Manned Spacecraft Center. Shih's research, and part of that by Bass, were accomplished while they were Visiting Scientists at the Lunar Science Institute, which is operated by the Universities Space Research Association under Contract No. NSR 09-051-001 with the National Aeronautics and Space Administration. We thank Dr. Paul W. Gast for his encouragement of this research and both Dr. Gast and NASA for making analytical facilities available.

\section{ANALYTICAL METHODS}

The analyses reported in Table 1 were measured largely by the X-ray fluorescence methods of Norrish and Hutton (1969), supplemented by other methods for certain elements. The X-ray fluorescence value for total $\mathrm{Fe}$ was coupled with $\mathrm{FeO}$ measured by classical methods to get the $\mathrm{Fe}_{2} \mathrm{O}_{3}$ values reported. $\mathrm{H}_{2} \mathrm{O}$ was measured by a modified Penfield method (Shapiro and Brannock, 1962, p. 46-48) and $\mathrm{Na}_{2} \mathrm{O}$ by atomic absorption. Total $\mathrm{C}$ was measured by the gas chromatographic method of Moore et al. (1970), and from it $\mathrm{CO}_{2}$ was calculated on the assumption that all $\mathrm{C}$ is present as carbonate. The portions of the rocks taken for chemical analysis were selected to avoid veins and large amygdules or replacement masses of calcite. The $\mathrm{CO}_{2}$ values represent, therefore, only small, unavoidable veins and patches of carbonate. S was measured both by X-ray fluorescence and by means of a LECO IR-32 automatic sulfur determinator. With this instrument, a powdered 25 to $50 \mathrm{mg}$ sample is combusted in oxygen at $1700^{\circ} \mathrm{C}$ over $\mathrm{V}_{2} \mathrm{O}_{5}$, and the resulting $\mathrm{SO}_{2}$ is measured with an infrared Luft cell. The agreement between the two sets of $\mathrm{S}$ values is good to satisfactory (Table 7).

Trace elements determined by X-ray fluorescence methods (Table 1) were measured nondestructively on powdered samples, and corrections for matrix effects were applied using either directly measured mass-absorption coefficients ( $\mathrm{Sr}, \mathrm{Rb}, \mathrm{Y}, \mathrm{Th}, \mathrm{Zr}, \mathrm{Nb}$ ), or, in the case of $\mathrm{C} 1$, coefficients calculated from the major element data (Norrish and Chappell, 1967).

For mass spectrometric analyses, aliquants of four rocks were selected and specially prepared in an effort to minimize contamination. The samples were ultrasonically cleaned in distilled water and then ground in an agate mortar. Because the powders were to be used for the measurement of trace element concentrations, they were 
TABLE 1

X-Ray Fluorescence Analyses, Volcanic Rocks, DSDP Leg 17

\begin{tabular}{|c|c|c|c|c|c|c|c|c|c|c|c|c|c|}
\hline \multirow{3}{*}{$\begin{array}{l}\text { Site/Hole } \\
\text { Core-Section } \\
\text { Interval }(\mathrm{cm})\end{array}$} & \multicolumn{2}{|c|}{164} & \multicolumn{4}{|c|}{$165 \mathrm{~A}$} & \multicolumn{2}{|c|}{166} & \multicolumn{2}{|c|}{167} & \multicolumn{3}{|c|}{169} \\
\hline & $28-1$ & $28-6$ & $24-1$ & $24-1$ & $26-2$ & $27-2$ & $29-2$ & $29-3$ & $94-3$ & $95-2$ & $5-1$ & $5-1$ & $6-3$ \\
\hline & 87 & 137 & $117-121 \mathrm{a}$ & $117-121^{b}$ & $80-84$ & $60-65$ & $19-22$ & $72-74$ & $78-84$ & $40-43$ & $21-24$ & $122-124$ & $433-38$ \\
\hline \multicolumn{14}{|l|}{ Weight (\%) } \\
\hline $\mathrm{SiO}_{2}$ & 46.61 & 47.76 & 44.17 & 44.02 & 42.63 & 41.46 & 49.24 & 47.86 & 47.42 & 44.93 & 46.04 & 45.83 & 45.15 \\
\hline $\mathrm{TiO}_{2}$ & 1.31 & 1.43 & 4.90 & 4.57 & 4.92 & 4.86 & 2.28 & 2.23 & 1.79 & 2.14 & 1.04 & 1.11 & 1.02 \\
\hline $\mathrm{Al}_{2} \mathrm{O}_{3}$ & 15.38 & 15.54 & 13.54 & 13.08 & 13.62 & 13.60 & 13.90 & 13.59 & 15.64 & 14.00 & 14.91 & 15.63 & 15.10 \\
\hline $\mathrm{Fe}_{2} \mathrm{O}_{3}$ & 5.82 & 5.41 & 6.59 & 6.50 & 4.83 & 5.69 & 3.44 & 6.63 & 5.83 & 7.05 & 6.61 & 4.77 & 4.11 \\
\hline $\mathrm{FeO}$ & 3.99 & 4.15 & 4.37 & 4.79 & 8.13 & 7.30 & 5.60 & 6.04 & 4.25 & 4.67 & 4.39 & 7.47 & 8.15 \\
\hline $\mathrm{MnO}$ & 0.16 & 0.18 & 0.32 & 0.36 & 0.25 & 0.22 & 0.17 & 0.23 & 0.16 & 0.21 & 0.19 & 0.19 & 0.20 \\
\hline $\mathrm{MgO}$ & 6.02 & 6.35 & 5.39 & 5.68 & 6.46 & 5.99 & 6.84 & 5.73 & 6.92 & 7.57 & 9.06 & 6.93 & 7.76 \\
\hline $\mathrm{CaO}$ & 12.50 & 11.73 & 9.26 & 10.81 & 8.14 & 9.00 & 10.60 & 10.08 & 9.43 & 7.12 & 6.87 & 10.96 & 10.38 \\
\hline $\mathrm{Na}_{2} \mathrm{O}$ & 3.24 & 3.49 & 3.74 & 3.82 & 3.61 & 4.46 & 3.82 & 3.45 & 3.84 & 3.64 & 2.98 & 3.48 & 3.59 \\
\hline $\mathrm{K}_{2} \mathrm{O}$ & 0.52 & 0.48 & 2.56 & 1.92 & 2.46 & 1.78 & 0.40 & 0.77 & 0.46 & 0.51 & 2.47 & 0.13 & 0.30 \\
\hline $\mathrm{H}_{2} \mathrm{O}^{+}$ & 1.01 & 0.55 & 0.14 & 0.52 & 1.34 & 2.22 & 0.65 & 0.90 & 1.22 & 1.17 & 3.44 & 1.80 & 1.71 \\
\hline $\mathrm{H}_{2} \mathrm{O}^{-}$ & 1.68 & 2.01 & 1.58 & 1.24 & 1.15 & 1.45 & 1.84 & 1.50 & 3.56 & 5.48 & 2.04 & 1.16 & 1.37 \\
\hline $\mathrm{P}_{2} \mathrm{O}_{5}$ & 0.12 & 0.13 & 1.21 & 0.88 & 1.41 & 1.28 & 0.20 & 0.20 & 0.20 & 0.22 & 0.08 & 0.10 & 0.10 \\
\hline S & 0.00 & 0.02 & 0.34 & 0.06 & 0.29 & 0.26 & 0.01 & 0.02 & 0.08 & 0.22 & 0.00 & 0.13 & 0.14 \\
\hline $\mathrm{CO}_{2}$ & 1.27 & 0.67 & 1.14 & 1.47 & 0.09 & 0.24 & 0.15 & 0.15 & 0.69 & 0.27 & 0.06 & 0.11 & 0.16 \\
\hline $\mathrm{Cl}$ & 0.01 & 0.02 & - & 0.06 & 0.12 & 0.06 & 0.01 & 0.01 & 0.08 & 0.04 & 0.04 & 0.00 & 0.00 \\
\hline-0 for $S$ & 0.00 & -0.01 & -0.17 & -0.03 & -0.14 & -0.13 & -0.01 & -0.01 & -0.04 & -0.11 & 0.00 & -0.06 & -0.07 \\
\hline-0 for $\mathrm{Cl}$ & 0.00 & 0.00 & - & -0.01 & -0.03 & -0.01 & 0.00 & 0.00 & -0.02 & -0.01 & -0.01 & 0.00 & 0.00 \\
\hline Total & 99.63 & 99.94 & 99.09 & 99.74 & 99.29 & 99.72 & 99.14 & 99.36 & 101.50 & 99.13 & 100.22 & 99.74 & 99.16 \\
\hline \multicolumn{14}{|l|}{ PPM: } \\
\hline $\mathrm{Cl}$ & 133 & 152 & - & 578 & 1170 & 630 & 89 & 92 & 757 & 369 & 448 & 30 & 49 \\
\hline $\mathrm{Sr}$ & 132 & 138 & 948 & 755 & 768 & 952 & 127 & 111 & 189 & 253 & 114 & 138 & 380 \\
\hline $\mathrm{Rb}$ & 5.8 & 8.9 & 25 & 18 & 28 & 20 & 4.4 & 13.6 & 2.2 & 2.1 & 20 & 2.3 & 2.3 \\
\hline $\mathrm{Y}$ & 27 & 28 & 27 & 27 & 30 & 28 & 49 & 43 & 24 & 30 & 15 & 18 & 17 \\
\hline Th & $<2$ & $<2$ & $<2$ & 3.5 & 3.2 & 3.5 & $<2$ & $<2$ & $<2$ & $<2$ & $<2$ & $<2$ & $<2$ \\
\hline $\mathrm{Zr}$ & 80 & 91 & 203 & 211 & 219 & 193 & 159 & 137 & 109 & 142 & 51 & 52 & 48 \\
\hline $\mathrm{Nb}$ & 4.3 & 4.3 & 62 & 52 & 68 & 61 & 3.4 & 2.6 & 5.3 & 14 & 3.7 & 4.4 & 3.9 \\
\hline
\end{tabular}

not washed in acid, as is the conventional procedure for samples to be analyzed isotopically for $\mathrm{Pb}, \mathrm{U}$, and $\mathrm{Th}$.

The REE were measured by the isotope dilution techniques of Gast et al. (1970). The Sr was isolated using conventional cation exchange chemistry (e.g., Gast et al., 1970) and isotopically analyzed using the triple Re filament ionization technique. The $\left(\mathrm{Sr}^{87} / \mathrm{Sr}^{86}\right)$ values given in Table 4 are normalized to $\left(\mathrm{Sr}^{86} / \mathrm{Sr}^{88}\right)=0.1194$. Two analyses of the NBS $987 \mathrm{SrCO}_{3}$ standard gave $\left(\mathrm{Sr}^{87} / \mathrm{Sr}^{86}\right)=0.71020 \pm$ 13. The $\mathrm{Sr}$ Concentration values by $\mathrm{X}$-ray fluorescence (Table 1) and isotope dilution (Table 3) are in good agreement.

The $\mathrm{U}$ and $\mathrm{Th}$ chemistry procedures are essentially identical to those of Tatsumoto (1966a). The Pb chemistry procedure has not been previously published, so it is briefly described below. Approximately 2.5 to 3 grams of rock are digested in covered teflon beakers using a 5:1 mixture of ultrapure $\mathrm{HF}$ and $\mathrm{HClO}_{4}$. The dried perchlorate cake is dissolved in a minimum volume of ultrapure concentrated $\mathrm{HC} 1$. The sample is precipitated using clean $\mathrm{NH}_{4} \mathrm{OH}$. The precipitate is then washed and redissolved in $\mathrm{HBr}$. The $\mathrm{Pb}$ is concentrated from the bromide medium on an anion exchange resin and rapidly eluted with $6 \mathrm{~N} \mathrm{HC} 1$. The $\mathrm{Pb}$ is cleaned by anion exchange in the $\mathrm{HCl}$ medium and eluted from the column with $\mathrm{H}_{2} \mathrm{O}$. The $\mathrm{Pb}$ sample is then prepared for mass spectrometry using the silica gel technique. Blanks in this procedure for 3-gram samples are about 10 nanograms. For $\mathrm{Pb}$ concentration measurements, a spiked sample is run through the same procedure. A fractionation correction of $0.2 \%$ /mass unit has been applied to the $\mathrm{Pb}$ isotopic data in Table 4 on the basis of the absolute determination of the CIT Pb standard by Catanzaro (1967).

The X-ray mineralogy was determined by powder patterns run on a Norelco diffractometer using Ni-filtered CuK radiation except for one ilmenite grain, which was $\mathrm{X}$-rayed in a powder camera. Chart speeds were one-half inch per minute, and goniometer speeds were $1 \%$ minute in mineral identification runs and $14^{\circ} /$ minute for the exact measurement of peak positions. In several cases, magnetic and density fractions of finely crushed rocks were separated by centrifuging in methylene iodide and bromoform and with a strong hand magnet. In the cases of highly altered rocks (e.g., Sites 167, 170, and 171), the fine dust and montmorillonite were removed by ultrasonic agitation followed by decanting in water.

Unit cell edges of opaque minerals with spinel structures (titanomagnetite, magnetite, maghemo-magnetite, maghemite) were calculated from $\mathrm{d}_{(440)}$ measured relative to an 
TABLE 1 - Continued

\begin{tabular}{|c|c|c|c|c|c|c|c|c|c|c|c|}
\hline \multirow{3}{*}{$\begin{array}{l}\text { Site/Hole } \\
\text { Core-Section } \\
\text { Interval }(\mathrm{cm})\end{array}$} & \multicolumn{3}{|c|}{169} & \multicolumn{5}{|c|}{170} & \multicolumn{3}{|c|}{171} \\
\hline & 6-4 & $12-1$ & $12-2$ & 170 & $16-1$ & $16-1$ & $16-1$ & $16-2$ & \multicolumn{3}{|c|}{$27-3$} \\
\hline & $140-141$ & $31-32$ & $115-117$ & $10-\mathrm{CC}$ & $17-19$ & $32-37$ & $32-37^{\mathrm{c}}$ & $144-147$ & 26-CC & $82-86$ & $33-\mathrm{CC}$ \\
\hline \multicolumn{12}{|l|}{ Weight (\%) } \\
\hline $\mathrm{SiO}_{2}$ & 45.37 & 48.94 & 49.44 & 50.78 & 51.36 & 46.33 & 46.89 & 46.95 & 44.70 & 45.42 & 45.56 \\
\hline $\mathrm{TiO}_{2}$ & 1.05 & 0.98 & 1.03 & 2.36 & 2.86 & 2.72 & 2.73 & 2.85 & 1.73 & 1.65 & 2.54 \\
\hline $\mathrm{Al}_{2} \mathrm{O}_{3}$ & 15.23 & 14.69 & 14.96 & 17.21 & 15.16 & 14.20 & 14.23 & 14.05 & 15.14 & 14.04 & 15.67 \\
\hline $\mathrm{Fe}_{2} \mathrm{O}_{3}$ & 4.76 & 3.89 & 4.19 & 6.76 & 7.10 & 4.30 & 4.44 & 5.55 & 6.05 & 4.19 & 7.38 \\
\hline $\mathrm{FeO}$ & 7.76 & 6.21 & 6.96 & 2.94 & 1.97 & 4.84 & 4.84 & 5.51 & 3.57 & 5.10 & 3.23 \\
\hline $\mathrm{MnO}$ & 0.20 & 0.17 & 0.18 & 0.11 & 0.12 & 0.20 & 0.20 & 0.13 & 0.05 & 0.10 & 0.12 \\
\hline $\mathrm{MgO}$ & 7.43 & 7.30 & 7.02 & 2.76 & 3.54 & 7.12 & 7.21 & 6.83 & 7.50 & 9.91 & 7.96 \\
\hline $\mathrm{CaO}$ & 10.48 & 12.75 & 12.56 & 6.32 & 4.78 & 6.85 & 6.90 & 6.88 & 7.19 & 7.04 & 7.48 \\
\hline $\mathrm{Na}_{2} \mathrm{O}$ & 3.52 & 2.80 & 2.91 & 5.78 & 3.47 & 4.05 & 4.05 & 4.52 & 3.71 & 3.62 & 2.96 \\
\hline $\mathrm{K}_{2} \mathrm{O}$ & 0.49 & 0.37 & 0.38 & 1.65 & 4.29 & 1.99 & 1.99 & 0.61 & 0.34 & 0.20 & 1.07 \\
\hline $\mathrm{H}_{2} \mathrm{O}^{+}$ & 1.82 & 0.61 & 0.64 & 1.69 & 2.06 & 1.12 & 1.12 & 1.19 & 2.43 & 2.37 & 2.65 \\
\hline $\mathrm{H}_{2} \mathrm{O}^{-}$ & 1.45 & 1.04 & 1.19 & 0.71 & 2.31 & 3.55 & 3.55 & 3.43 & 6.02 & 4.86 & 2.29 \\
\hline $\mathrm{P}_{2} \mathrm{O}_{5}$ & 0.09 & 0.07 & 0.11 & 1.26 & 0.32 & 0.30 & 0.30 & 0.32 & 0.24 & 0.19 & 0.35 \\
\hline $\mathrm{S}$ & 0.11 & 0.02 & 0.01 & 0.01 & 0.01 & 0.10 & 0.08 & 0.04 & 0.04 & 0.04 & 0.00 \\
\hline $\mathrm{CO}_{2}$ & 0.13 & 0.33 & 0.18 & 0.06 & 0.30 & 1.53 & 1.53 & 0.16 & 1.11 & 0.34 & 0.23 \\
\hline $\mathrm{Cl}$ & 0.01 & 0.01 & 0.01 & 0.04 & 0.12 & 0.05 & 0.05 & 0.04 & 0.04 & 0.02 & 0.01 \\
\hline-0 for $S$ & -0.06 & -0.01 & -0.01 & 0.00 & 0.00 & -0.05 & -0.04 & -0.02 & -0.02 & -0.02 & 0.00 \\
\hline-0 for $\mathrm{Cl}$ & 0.00 & 0.00 & 0.00 & -0.01 & -0.03 & -0.01 & -0.01 & -0.01 & -0.01 & -0.01 & 0.00 \\
\hline Total & 99.84 & 100.17 & 101.77 & 100.43 & 99.75 & 99.18 & 100.07 & 99.03 & 99.83 & 99.07 & 99.49 \\
\hline \multicolumn{12}{|l|}{ PPM: } \\
\hline $\mathrm{Cl}$ & 123 & 126 & 120 & 426 & 1185 & 474 & 474 & 407 & 415 & 225 & 138 \\
\hline $\mathrm{Sr}$ & 165 & 109 & 107 & 1213 & 369 & 340 & 340 & 360 & 312 & 266 & 296 \\
\hline $\mathrm{Rb}$ & 7.7 & 6.6 & 7.8 & 107 & 210 & 15 & 15 & 4.7 & 6.3 & 0.9 & 14 \\
\hline$X$ & 17 & 18 & 19 & 43 & 16 & 22 & 22 & 20 & 24 & 22 & 34 \\
\hline Th & $<2$ & $<2$ & $<2$ & 5.6 & $<2$ & $<2$ & $<2$ & $<2$ & $<2$ & $<2$ & 2.5 \\
\hline $\mathrm{Zr}$ & 49 & 51 & 51 & 495 & 155 & 145 & 145 & 146 & 141 & 136 & 247 \\
\hline $\mathrm{Nb}$ & 2.8 & 1.9 & 2.9 & 83 & 27 & 26 & 26 & 27 & 18 & 17 & 25 \\
\hline
\end{tabular}

${ }^{\mathrm{a}}$ Host.

$\mathrm{b}_{\text {Inclusion. }}$.

cRepeat.

internal silicon standard. Fresh olivine was found only in the diabase sill at Site 169; its composition was estimated from $\mathrm{d}_{(130)}$, measured relative to an internal silicon standard, using the curve of Yoder and Sahama (1957). The $\mathrm{MgCO}_{3}$ contents of calcites were estimated from $\mathrm{d}_{(211)}$ and $\mathrm{d}_{(633)}$, measured relative to an internal silicon standard, agree generally within 0.5 mole $\% \mathrm{MgCO}_{3}$.

In some cases where plagioclase peaks were sufficiently distinct in the powder patterns, the peak separations $\Delta 2 \theta=$ $2 \theta(131)-2 \theta(1 \overline{3} 1)$, and $\Gamma=2 \theta(131)+2 \theta(220)-4 \theta$ (15i1) were measured, and compositions estimated, by means of the curves of Smith and Yoder (1956) and Smith and Gay (1958), respectively. In the absence of information on Al-Si ordering in the plagioclase, only limiting compositions, or a maximum An content, can be given in most cases. Thus, plagioclases in rocks from Sites 169, 170, and 171 (Appendix A) are merely confirmed as probably lying in the range of labradorite to sodic bytownite, as expected for plagioclase in basalt. At Site 167, on the other hand, it is established that the cores of xenocrysts(?) contain at least some sodic anorthite; and in the mugearite from Site 170 and the hawaiites (and possibly one mugearite) from
Hole $165 \mathrm{~A}$, the sodic nature of the plagioclase is confirmed, in agreement with expectation from the bulk chemistry (Table 1).

In most cases the $(\overline{2} 01)$ feldspar peak is near $22^{\circ} 2 \theta$ and indicates a plagioclase. Diagenetic feldspar, which replaces plagioclase, gives a $(\overline{2} 01)$ peak near $21^{\circ}$ and appears to be essentially pure K-feldspar. In the X-ray patterns of some of the light, nonmagnetic fractions of alkaline rocks from Hole $165 \mathrm{~A}$, one sees the $(\overline{2} 01)$ peaks of $\mathrm{K}$-feldspar and plagioclase and, in addition, a third peak which is interpreted as

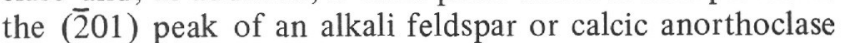
which probably occurs interstitially or as late mantles on plagioclase.

Phyllosilicates were identified by the positions of various X-ray peaks, especially basal peaks, before and after exposure to ethylene glycol. If the (001) d-value is about used. Montmorillonites have (001) d-values that expand from $14 \AA$ or less before glycolation to more than $17 \AA$ on exposure to ethylene glycol. If the $(001) \mathrm{d}$-value is about $12.5 \AA\left(6.9\right.$ to $\left.7.1^{\circ} 2 \theta\right)$ before glycolation, the exchangeable interlayer cations are interpreted to be largely $\mathrm{Na}$ (Appendix A), whereas d-values of $15 \AA$ or more (5.8 to 
TABLE 2

Molecular Norms of Chemically Analyzed Volcanic Rocks, DSDP Leg 17

\begin{tabular}{|c|c|c|c|c|c|c|c|c|c|c|c|c|}
\hline \multirow{3}{*}{$\begin{array}{l}\text { Site/Hole } \\
\text { Core-Section } \\
\text { Interval }(\mathrm{cm})\end{array}$} & \multicolumn{2}{|c|}{164} & \multicolumn{4}{|c|}{$165 \mathrm{~A}$} & \multicolumn{2}{|c|}{166} & \multicolumn{2}{|c|}{167} & \multicolumn{2}{|c|}{169} \\
\hline & $28-1$ & $28-1$ & 24-1 & 24-1 & $26-2$ & $27-2$ & 29-2 & $29-3$ & 94-3 & $95-2$ & $5-1$ & $5-1$ \\
\hline & 87 & 137 & $117-121^{\mathrm{a}}$ & $117-121^{b}$ & $80-84$ & $60-65$ & $19-22$ & $72-74$ & $78-84$ & $40-43$ & $21-24$ & $122-124$ \\
\hline Q & - & - & - & - & - & - & - & $(0 . \overline{9})$ & - & - & - & - \\
\hline OR & 3.17 & 2.91 & 15.68 & 11.73 & 15.24 & 11.04 & 2.44 & 4.77 & 2.80 & 3.26 & 15.31 & 0.79 \\
\hline $\mathrm{AB}$ & $\begin{array}{c}26.42 \\
(29.95)\end{array}$ & $\begin{array}{c}28.15 \\
(32.09)\end{array}$ & $\begin{array}{c}24.25 \\
(28.23)\end{array}$ & $\begin{array}{r}21.98 \\
26.85)\end{array}$ & $\begin{array}{c}18.71 \\
(23.43)\end{array}$ & $\begin{array}{c}16.06 \\
(21.97)\end{array}$ & $\begin{array}{c}34.88 \\
(35.36)\end{array}$ & $\begin{array}{c}31.53 \\
(32.38)\end{array}$ & $\begin{array}{c}34.79 \\
(34.90)\end{array}$ & 35.07 & $\begin{array}{l}19.25 \\
(26.74)\end{array}$ & $\begin{array}{c}23.18 \\
(27.87)\end{array}$ \\
\hline AN & 26.78 & 26.05 & 13.07 & 13.54 & 14.83 & 12.66 & 20.31 & 20.30 & 25.25 & 22.18 & $\begin{array}{c}(20.14) \\
21.19\end{array}$ & $\begin{array}{c}(27.87) \\
27.61\end{array}$ \\
\hline DI & 22.53 & 22.79 & 15.13 & 21.08 & 13.81 & 19.08 & 25.38 & 23.81 & 13.79 & 10.12 & 10.90 & 21.80 \\
\hline$\overline{\mathrm{HY}}$ & $(4.71)$ & $(3.18)$ & - & - & - & - & $(4 . \overline{56})$ & $(6 . \overline{35})$ & $(10 . \overline{0})$ & $\begin{array}{c}2.79 \\
(14.84)\end{array}$ & - & - \\
\hline $\mathrm{OL}$ & $\begin{array}{l}12.41 \\
(1.13)\end{array}$ & $\begin{array}{l}12.54 \\
(3.06)\end{array}$ & $\begin{array}{l}10.69 \\
(5.90)\end{array}$ & $\begin{array}{l}10.09 \\
(4.25)\end{array}$ & $\begin{array}{c}15.98 \\
(10.32)\end{array}$ & $\begin{array}{l}13.05 \\
(5.97)\end{array}$ & $\begin{array}{l}11.52 \\
(4.09)\end{array}$ & $\begin{array}{c}13.48 \\
(-)\end{array}$ & $\begin{array}{l}17.24 \\
(2.09)\end{array}$ & $\begin{array}{l}20.12 \\
(2.04)\end{array}$ & $\begin{array}{c}25.16 \\
(16.18)\end{array}$ & $\begin{array}{c}17.32 \\
(11.70)\end{array}$ \\
\hline $\mathrm{NE}$ & $\begin{array}{l}2.11 \\
(-)\end{array}$ & $\begin{array}{l}2.36 \\
(-)\end{array}$ & $\begin{array}{l}6.35 \\
(3.95)\end{array}$ & $\begin{array}{c}7.81 \\
(4.89)\end{array}$ & $\begin{array}{c}8.60 \\
(5.77)\end{array}$ & $\begin{array}{c}15.31 \\
(11.77)\end{array}$ & $\begin{array}{l}0.29 \\
(-)\end{array}$ & $\begin{array}{r}0.51 \\
((-)\end{array}$ & $\begin{array}{l}0.06 \\
(-)\end{array}$ & - & $\begin{array}{c}5.07 \\
(0.58)\end{array}$ & $\begin{array}{c}5.43 \\
(2.62)\end{array}$ \\
\hline MT & $\begin{array}{c}1.11 \\
(6.28)\end{array}$ & $\begin{array}{c}1.07 \\
(5.81)\end{array}$ & $\begin{array}{l}1.24 \\
(-)\end{array}$ & $\begin{array}{c}1.28 \\
(1.47)\end{array}$ & $\begin{array}{c}1.52 \\
(5.30)\end{array}$ & $\begin{array}{c}1.52 \\
(6.25)\end{array}$ & $\begin{array}{c}1.05 \\
(3.72)\end{array}$ & $\begin{array}{c}1.46 \\
(7.27)\end{array}$ & $\begin{array}{c}1.14 \\
(6.11)\end{array}$ & $\begin{array}{l}1.38 \\
(6.28) 1\end{array}$ & $\begin{array}{c}1.26 \\
(7.25)\end{array}$ & $\begin{array}{l}1.42 \\
(5.16)\end{array}$ \\
\hline IL & 1.88) & 2.05 & $\begin{array}{r}7.08 \\
(6.41) \\
\end{array}$ & 6.58 & 7.19 & 7.11 & 3.28 & 3.26 & 2.57 & 3.23 & 1.52 & 1.60 \\
\hline $\mathrm{HM}$ & - & - & $\overline{(4.76)}$ & $(3.70)$ & - & - & - & - & $(0 . \overline{12})$ & $(\overline{1.13})$ & - & - \\
\hline AP & 0.26 & 0.28 & 2.62 & 1.90 & 3.09 & 2.81 & 0.43 & 0.44 & 0.43 & 0.50 & 0.50 & 0.18 \\
\hline $\mathrm{CC}$ & 3.32 & 1.74 & 2.99 & 3.84 & 0.24 & 0.64 & 0.39 & 0.40 & 1.80 & 0.74 & 0.16 & 0.29 \\
\hline PR & - & 0.05 & 0.92 & 0.16 & 0.79 & 0.71 & 0.03 & 0.06 & 0.22 & 0.62 & - & 0.35 \\
\hline RU & - & - & $(0.34)$ & - & - & - & - & - & - & - & - & - \\
\hline \multirow{3}{*}{$\begin{array}{l}\text { Site/Hole } \\
\text { Core-Section } \\
\text { interval }(\mathrm{cm})\end{array}$} & \multicolumn{4}{|c|}{169} & \multicolumn{5}{|c|}{170} & \multirow{2}{*}{\multicolumn{3}{|c|}{$\begin{array}{r}171 \\
27-3 \\
\end{array}$}} \\
\hline & $6-3$ & $6-4$ & $12-1$ & $12-2$ & & $16-1$ & $16-1$ & $16-1$ & $16-2$ & & & \\
\hline & 33-38 & $140-141$ & $31-32$ & $115-117$ & $10-\mathrm{CC}$ & $17-19$ & $32-37$ & $32-37^{c}$ & $144-147$ & $26-\mathrm{CC}$ & $82-86$ & 33-CC \\
\hline Q & - & - & $(2 . \overline{83})$ & - & - & $(2.83)$ & - & - & - & - & - & - \\
\hline OR & 1.84 & 2.99 & 2.23 & 2.26 & 9.96 & 26.97 & 12.30 & 12.20 & 3.81 & 2.18 & 1.26 & 6.71 \\
\hline $\mathrm{AB}$ & $\begin{array}{c}20.97 \\
(24.75)\end{array}$ & $\begin{array}{c}19.88 \\
(24.51)\end{array}$ & 25.50 & 26.22 & $\begin{array}{l}46.93 \\
52.40)\end{array}$ & 32.20 & $\begin{array}{c}35.77 \\
(37.67)\end{array}$ & $\begin{array}{c}36.32 \\
(37.36)\end{array}$ & $\begin{array}{c}40.12 \\
(42.57)\end{array}$ & 35.72 & 34.69 & 28.10 \\
\hline $\mathrm{AN}$ & 25.09 & 25.20 & 26.94 & 26.87 & 16.68 & 14.44 & 15.56 & 15.52 & 17.39 & 25.84 & 23.03 & 27.96 \\
\hline DI & 21.25 & 21.71 & 27.89 & 27.22 & 5.25 & 5.24 & 6.26 & 6.35 & 12.37 & 2.82 & 8.58 & 5.95 \\
\hline HY & - & - & $\begin{array}{c}0.97 \\
(6.95)\end{array}$ & (6.31) & - & $\begin{array}{l}11.66 \\
(7.78)\end{array}$ & $(4.23)$ & $\overline{(5.83)}$ & $(5.77)$ & $\begin{array}{c}10.36 \\
(20.54)\end{array}$ & $\begin{array}{c}4.83 \\
(12.00)\end{array}$ & $\begin{array}{c}8.50 \\
(18.55)\end{array}$ \\
\hline $\mathrm{OL}$ & $\begin{array}{c}19.50 \\
(14.97)\end{array}$ & $\begin{array}{c}18.80 \\
(13.25)\end{array}$ & $\begin{array}{l}12.90 \\
(3.92)\end{array}$ & $\begin{array}{l}14.02 \\
(4.55)\end{array}$ & $\begin{array}{l}10.44 \\
(3.87)\end{array}$ & $\begin{array}{l}2.68 \\
(-)\end{array}$ & $\begin{array}{c}18.96 \\
(10.33)\end{array}$ & $\begin{array}{c}19.10 \\
(9.10)\end{array}$ & $\begin{array}{c}18.10 \\
(6.50)\end{array}$ & $\begin{array}{c}15.64 \\
(0.37)\end{array}$ & $\begin{array}{c}22.59 \\
(11.84)\end{array}$ & $\begin{array}{l}16.41 \\
(1.35)\end{array}$ \\
\hline $\mathrm{NE}$ & $\begin{array}{c}7.45 \\
(5.19)\end{array}$ & $\begin{array}{c}7.63 \\
(4.85)\end{array}$ & - & $\begin{array}{l}0.004 \\
(-)\end{array}$ & $\begin{array}{c}3.44 \\
(0.15)\end{array}$ & & $\begin{array}{l}1.14 \\
(-)\end{array}$ & $\begin{array}{l}0.63 \\
(-)\end{array}$ & $\begin{array}{l}1.47 \\
(-)\end{array}$ & - & - & - \\
\hline MT & $\begin{array}{c}1.43 \\
(4.45)\end{array}$ & $\begin{array}{c}1.45 \\
(5.15)\end{array}$ & $\begin{array}{c}1.15 \\
(4.14)\end{array}$ & $\begin{array}{c}1.25 \\
(4.41)\end{array}$ & $\begin{array}{c}1.07 \\
(1.92)\end{array}$ & $\begin{array}{l}1.04 \\
(-)\end{array}$ & $\begin{array}{c}1.06 \\
(4.70)\end{array}$ & $\begin{array}{c}1.06 \\
(4.82)\end{array}$ & $\begin{array}{c}1.30 \\
(6.14)\end{array}$ & $\begin{array}{c}1.13 \\
(4.96)\end{array}$ & $\begin{array}{c}1.10 \\
(4.69)\end{array}$ & $\begin{array}{l}1.22 \\
(2.33)\end{array}$ \\
\hline IL & 1.47 & 1.51 & 1.39 & 1.45 & 3.36 & $\begin{array}{c}4.24 \\
(3.23) \\
\end{array}$ & $\begin{array}{c}3.97 \\
(3.96) \\
\end{array}$ & 3.95 & 4.20 & 2.61 & 2.46 & 3.75 \\
\hline HM & - & - & - & - & $(3.54)$ & $(5.27)$ & - & - & - & $\overline{(1.26)}$ & - & $(3 . \overline{90})$ \\
\hline AP & 0.22 & 0.20 & 0.15 & 0.23 & 2.69 & 0.71 & 0.66 & 0.65 & 0.71 & 0.54 & 0.43 & 0.78 \\
\hline $\mathrm{CC}$ & 0.42 & 0.34 & 0.85 & 0.46 & 0.16 & 0.81 & 4.05 & 4.02 & 0.43 & 3.04 & 0.92 & 0.62 \\
\hline PR & 0.38 & 0.30 & 0.05 & 0.03 & 0.03 & 0.03 & 0.27 & 0.22 & 0.11 & 0.11 & 0.11 & - \\
\hline RU & - & - & - & - & - & $(0.51)$ & - & - & - & - & - & - \\
\hline
\end{tabular}

$6.0^{\circ} 2 \theta$ ) are interpreted to indicate interlayer cations other than $\mathrm{Na}$. The powders were smeared in water and allowed to dry in air under fairly constant conditions of relative humidity so the differences in peak positions are assumed to be significant. In many cases, a single broad peak was found, indicating a range of d-values and presumably a range of interlayer cation populations. In other cases, two distinct peaks were found and are interpreted as due to two distinct types of montmorillonite, Na-saturated, and nonNa-saturated. These types may correspond to the various colors, grain sizes, and textural types of montmorillonite seen in the various rocks concerned.

Micas (celadonites) have nonexpandable $10 \AA$ peaks. The relatively well-crystallized $1 \mathrm{M}$ micas have distinct $10 \AA$ peaks; the $1 \mathrm{Md}$ types have weak $10 \AA$ peaks or none at all. In rare cases the peak shifts slightly on exposure to ethylene glycol, suggesting a minor amount of randomly interlayered montmorillonite in the mica. At Site 171, a distinct mixed-layer mica-montmorillonite phase is found in altered glass. Its broad 10.8 to $11 \AA$ basal peak expands somewhat on exposure to ethylene glycol without splitting into two peaks. A significant amount of montmorillonite is interlayered with the mica in this phase, but the mica is still dominant.

Chlorite has nonexpandable $14 \AA$ and $7 \AA$ peaks. In Mg-rich types (veins in diabase from Site 169), the $14 \AA$ peak is the more intense. Mixed-layer chlorite-montmorillonites similarly have $14 \AA$ and $7 \AA$ peaks, but they expand 
TABLE 3

Trace Elements by Isotope Dilution Analysis, DSDP Leg 17 Cores

\begin{tabular}{lcccc}
\hline & $\begin{array}{c}164-28-1, \\
87 \mathrm{~cm}^{\mathrm{a}}\end{array}$ & $\begin{array}{c}169-6-4 \\
140-141 \mathrm{~cm}^{\mathrm{b}}\end{array}$ & $\begin{array}{c}169-12-1 \\
3-32 \mathrm{~cm}^{\mathrm{a}}\end{array}$ & $170-10-\mathrm{CC}^{\mathrm{c}}$ \\
\hline $\mathrm{U}$ & 0.093 & 0.087 & 0.061 & 1.46 \\
$\mathrm{Th}$ & & 0.281 & 0.200 & 4.97 \\
$\mathrm{~Pb}$ & & 1.43 & 0.41 & 2.63 \\
$\mathrm{Ba}$ & 18.0 & 80.6 & 7.05 & 302 \\
$\mathrm{La}$ & 4.81 & 3.57 & 2.25 & 60.6 \\
$\mathrm{Ce}$ & 10.8 & 6.22 & 10.4 & 128 \\
$\mathrm{Nd}$ & 9.05 & 6.74 & 6.03 & 74.2 \\
$\mathrm{Sm}$ & 2.98 & 2.03 & 2.06 & 16.0 \\
$\mathrm{Eu}$ & 1.11 & 0.811 & 0.809 & 4.95 \\
$\mathrm{Cd}$ & 4.13 & - & 2.80 & 14.1 \\
$\mathrm{Dy}$ & 4.64 & 3.07 & 3.27 & 8.82 \\
$\mathrm{Er}$ & 3.11 & 1.93 & 2.05 & 3.20 \\
$\mathrm{Yb}$ & 3.11 & 2.02 & 2.08 & 2.21 \\
$\mathrm{Sr}$ & - & 169 & 109 & 1094 \\
\hline
\end{tabular}

Note: Concentrations are in $\mathrm{ppm}$.

${ }^{\mathrm{a}}$ Basement pillow basalt.

$\mathrm{b}_{\text {Sill. }}$.

c Flow, sill or clasts in turbidite.

$\mathrm{d}_{\text {These }} \mathrm{Sr}$ values are in good to satisfactory agreement with the X-ray fluorescence values in Table 1.

on exposure to ethylene glycol. The $14 \AA$ peak does not expand as much as (001) of montmorillonite; the $7 \AA$ peak broadens and decreases in height as it expands. Where pure chlorite coexists with mixed-layer chlorite-montmorillonite, the $7 \AA$ peak becomes skewed to the low-angle side and decreases in height as the expandable part broadens and shifts.

Serpentine was identified only in veins in diabase from Site 169. No other $7 \AA$ clay, such as kaolinite, nor vermiculite, nor any chain clay, was found in rocks from any site. The peaks of the mixed-layer chlorite-montmorillonites were never sufficiently intense and sharp to establish the existence of a superorder reflection, so the presence or absence of corrensite could not be confirmed.

Modal analyses of thin sections represent more than 2000 points in all cases and more than 3000 in most. Detailed petrographic notes beyond those in this chapter are available from the Deep Sea Drilling Project. The additional data are mostly textural and other observations on the components distinguished in the modes.

\section{PETROCHEMISTRY}

\section{Diagenetic Alteration}

Many of the rocks recovered during Leg 17 are so altered that many chemical elements are disturbed and cannot be used to interpret the original rock and magma types. This is especially true at Sites 167, 170, and 171 . The changes are associated mineralogically with the appearance of intersertal montmorillonite and the filling of fractures, amygdules, and interpillow and interflow voids by calcite, montmorillonite, or both. The montmorillonite formed primarily by replacement of mafic minerals and late $\mathrm{Fe}$ - and Ti-rich interstitial residua, and to a minor extent, by replacement of plagioclase. The formation of both montmorillonite and calcite was promoted by high $\mathrm{CO}_{2}$ activities; but, whereas most of the montmorillonite was precipitated locally as pseudomorphs of the replaced phases, the Ca migrated preferentially to megascopic pore spaces prior to precipitation as calcite. Therefore, the abundance of calcite and the concentration of $\mathrm{CaO}$ in a rock will vary with the abundance of calcite veins and amygdules. These, in turn, vary in a manner related, not to the original rock chemistry, but to primary porosity. An approximation to a closed chemical system for components other than $\mathrm{H}_{2} \mathrm{O}$ and oxygen would require sampling an

TABLE 4

Isotopic Data, DSDP Leg 17 Cores (Atomic Ratios)

\begin{tabular}{|c|c|c|c|c|c|c|c|c|}
\hline & $\mathrm{Rb} / \mathrm{Sr}^{\mathrm{a}}$ & $\mathrm{Sr} 87 / \mathrm{Sr}^{86^{b}}$ & $\mathrm{U}^{238} / \mathrm{Pb}^{204 \mathrm{c}}$ & $\mathrm{Th}^{232} / \mathrm{U}^{238^{\mathrm{d}}}$ & $\mathrm{Pb}^{206 / \mathrm{Pb}^{204}}$ & $\mathrm{~Pb}^{207 / \mathrm{Pb}^{204}}$ & $\mathrm{~Pb}^{208 / \mathrm{Pb}} 204$ & $\mathrm{Age}^{\mathrm{e}}$ \\
\hline \multirow{2}{*}{$\begin{array}{l}164-28-1,87 \mathrm{~cm} \\
\text { (basement pillow } \\
\text { basalt) }\end{array}$} & 0.045 & 0.7038 & & & & & & 0 \\
\hline & & 0.7036 & & & & & & 95 \\
\hline $\begin{array}{l}\text { 169-6-4, } \\
140-141 \mathrm{~cm} \text { (sill) }\end{array}$ & 0.048 & $\begin{array}{l}0.7039 \\
0.7037\end{array}$ & 3.93 & 3.34 & $\begin{array}{l}19.515 \\
19.457\end{array}$ & $\begin{array}{l}15.674 \\
15.672\end{array}$ & $\begin{array}{l}39.271 \\
39.210\end{array}$ & $\begin{array}{r}0 \\
95\end{array}$ \\
\hline $\begin{array}{l}169-12-1,31-32 \mathrm{~cm} \\
\text { (basement pillow } \\
\text { basalt) }\end{array}$ & 0.062 & $\begin{array}{l}0.7040 \\
0.7038\end{array}$ & 9.4 & 3.39 & $\begin{array}{l}18.532 \\
18.395\end{array}$ & $\begin{array}{l}15.547 \\
15.541\end{array}$ & $\begin{array}{l}38.376 \\
38.226\end{array}$ & $\begin{array}{r}0 \\
95\end{array}$ \\
\hline $\begin{array}{l}170-10-\mathrm{CC} \\
\text { (flow, sill or } \\
\text { clasts in turbidite) }\end{array}$ & 0.090 & $\begin{array}{l}0.7033 \\
0.7031 \\
0.7030\end{array}$ & 35.9 & 3.51 & $\begin{array}{l}19.888 \\
19.555 \\
19.360\end{array}$ & $\begin{array}{l}15.580 \\
15.564 \\
15.555\end{array}$ & $\begin{array}{l}39.454 \\
39.07 \\
38.89\end{array}$ & $\begin{array}{r}0 \\
65 \\
95\end{array}$ \\
\hline
\end{tabular}

aFrom X-ray fluorescence data in Table 1. Compare isotope dilution values for $\mathrm{Sr}$ in Table 3.

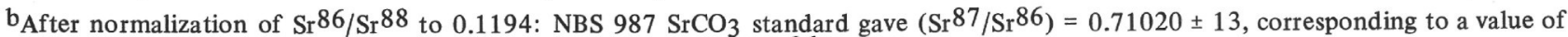
0.7080 for the Eimer and Amend standard; uncertainties in $\mathrm{Sr} 87 / \mathrm{Sr} 86$ are \pm 0.0002 .

cobserved $\mu$ based on concentration data in Table 3 .

d Observed $K$ based on concentration data in Table 3.

eAge (m.y.) to which observed $\mathrm{Sr}$ and $\mathrm{Pb}$ isotope ratios are corrected for growth of radiogenic isotopes since magma emplacement, based on observed $\mathrm{Rb} / \mathrm{Sr}, \mu$ and $K$ given in this table. 
TABLE 5

Opaque Minerals from Selected Specimens, Volcanic Rocks, DSDP Leg 17 Cores

\begin{tabular}{|c|c|c|c|c|c|c|c|c|}
\hline \multirow[b]{2}{*}{ Specimen } & \multicolumn{3}{|c|}{ Magnetic Spinel } & \multirow[b]{2}{*}{ Anatase $^{\mathrm{C}}$} & \multirow[b]{2}{*}{ Ilmenite ${ }^{c}$} & \multicolumn{2}{|c|}{ Nonmagnetic Spinel } & \multirow[b]{2}{*}{ Pyrite $^{c}$} \\
\hline & $a_{0}(\AA)^{a}$ & Name & $\begin{array}{c}\text { Mole \% } \\
\text { Ulvospinel } b\end{array}$ & & & $a_{0}(\AA)^{a}$ & Name & \\
\hline $\begin{array}{l}165 \mathrm{~A}-24-1,117-121 \mathrm{~cm} \\
\text { Hawaiite host }\end{array}$ & 8.407 & Titanomagnetite & 15 & $\mathrm{X} ?$ & $\mathrm{XXX}$ & & & \\
\hline $\begin{array}{l}\text { 165A-24-1, 117-121 cm } \\
\text { Hawaiite inclusion }\end{array}$ & 8.392 & Magnetite & 0 & & & & & \\
\hline $\begin{array}{l}165 \text { A-26-2, } 80-84 \mathrm{~cm} \\
\text { Hawaiite }\end{array}$ & 8.399 & Titanomagnetite & 10 & & $\mathrm{XXX}$ & & & $\mathrm{X}$ \\
\hline $\begin{array}{l}165 \mathrm{~A}-27-2,60-65 \mathrm{~cm} \\
\text { Hawaiite or mugearite }\end{array}$ & 8.405 & Titanomagnetite & 15 & & $\mathrm{XXX}$ & & & $\mathbf{X}$ \\
\hline $\begin{array}{l}165 \mathrm{~A}-27-\mathrm{CC} \\
\text { Hawaiite }\end{array}$ & 8.402 & Titanomagnetite & 12 & & $\mathrm{XXX}$ & & & $\mathrm{X} ?$ \\
\hline $\begin{array}{l}\text { 166-29-CC } \\
\text { Basalt }\end{array}$ & 8.380 & Maghemo-magnetite & 0 & $\mathrm{X} ?$ & & & & \\
\hline $\begin{array}{l}167-94-3,78-84 \mathrm{~cm} \\
\text { Basalt }\end{array}$ & 8.412 & Titanomagnetite & 22 & $\mathrm{X}$ & & & & \\
\hline $\begin{array}{l}169-5-1,21-24 \mathrm{~cm} \\
\text { Diabase }\end{array}$ & 8.366 & Maghemite & 0 & $\mathrm{X}$ & $\mathrm{X}$ ? & & & \\
\hline $\begin{array}{l}\text { 169-6-3, } 33-38 \mathrm{~cm} \\
\text { Diabase }\end{array}$ & 8.466 & Titanomagnetite & 61 & & & & & \\
\hline $\begin{array}{l}\text { 169-6-4, } 140-141 \mathrm{~cm} \\
\text { Diabase }\end{array}$ & 8.464 & Titanomagnetite & 60 & & & & & \\
\hline $\begin{array}{l}169-6-5,141-144 \mathrm{~cm} \\
\text { Basalt }\end{array}$ & $\begin{array}{l}8.395 \\
8.461\end{array}$ & $\begin{array}{l}\text { Magnetite } \\
\text { Titanomagnetite }\end{array}$ & $\begin{array}{r}0 \\
58\end{array}$ & & $\mathrm{X} ?$ & & & \\
\hline $\begin{array}{l}170-16-1,17-24 \mathrm{~cm} \\
\text { Basalt (green) }\end{array}$ & 8.381 & Maghemo-magnetite & 0 & $\mathrm{XX}$ & $\mathrm{X} ?$ & & & \\
\hline $\begin{array}{l}170-16-1,24-37 \mathrm{~cm} \\
\text { Basalt (gray) }\end{array}$ & 8.393 & Magnetite & 0 & $\mathrm{XX}$ & $\mathrm{XX}$ & & & $X$ \\
\hline $\begin{array}{l}170-16-2,135-150 \mathrm{~cm} \\
\text { Basalt }\end{array}$ & 8.408 & Titanomagnetite & 19 & & $\mathrm{XX}$ & & & $\mathrm{X}$ \\
\hline $\begin{array}{l}\text { 171-26-CC } \\
\text { Basalt }\end{array}$ & 8.412 & Titanomagnetite & 22 & $\mathrm{X}$ & $\mathrm{X}$ & 8.273 & Picotite? & \\
\hline $\begin{array}{l}171-27-3,80-92 \mathrm{~cm} \\
\text { Basalt }\end{array}$ & 8.393 & Magnetite & 0 & & $\mathrm{X}$ & 8.253 & Picotite? & \\
\hline $\begin{array}{l}\text { 171-33-CC } \\
\text { Basalt }\end{array}$ & 8.347 & Maghemite & 0 & & $\mathrm{XXX}$ & & & \\
\hline
\end{tabular}

${ }_{\text {From }} \mathrm{d}_{(440)}$ measured rela tive to an internal silicon standard.

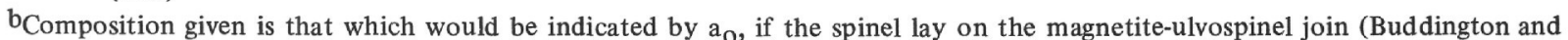
Lindsley, 1964). Relative $\mathrm{TiO}_{2}$ contents are probably real.

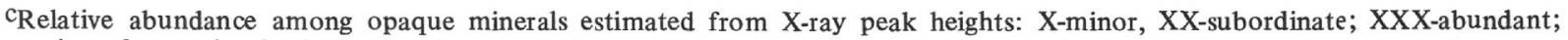
pyrite refers to that in the host rock, not in veins or other segregations.

impractically large volume of rock. Consequently, megascopic calcite was avoided in selecting rocks for analysis, and the analyses of highly altered rocks show low $\mathrm{CaO}$ concentrations. The analyses are interpreted accordingly. The calcites are low in MgO (Table 7) so Mg evidently did not migrate during diagenesis to an extent comparable to that of Ca. Matthews (1971) and Bass (unpublished data on rocks dredged from the Gulf of Panama) find marked reductions of $\mathrm{MgO}$ in some cases. The rocks concerned were not buried throughout their histories, and the $\mathrm{MgO}$ losses may be due to processes related to relatively free contact with oxygenated bottom waters.

Preliminary chemical evidence (to be reported elsewhere) indicates that the montmorillonites chemically reflect their substrate as regards octahedrally and tetrahedrally coordinated cations. Montmorillonite that replaces plagioclase is generally light green to amost colorless and presumably aluminous. That which replaces pyroxenes and interstitial residua is commonly more deeply colored in shades of green and brown, is rich in $\mathrm{Mg}$ and $\mathrm{Fe}$, and is relatively poor in $\mathrm{Al}$. That which replaces olivine is often light to medium green and presumably rich in $\mathrm{Mg}$; where it is pigmented with dusty Fe-oxide, the intrinsic colors are disguised. The montmorillonite forms in most cases before $\mathrm{Fe}$ is completely oxidized, so the clays are not nontronites and $\mathrm{FeO}$ equals or exceeds $\mathrm{Fe}_{2} \mathrm{O}_{3}$. The common ferric oxide pigmentation of pseudomorphs after olivine is in agreement with the early alteration of olivine when the 
TABLE 6

Calcite from Selected Specimens, Volcanic Rocks, DSDP Leg 17 Cores

\begin{tabular}{|c|c|c|}
\hline Specimen & Mode of Occurrence & Mole $\% \mathrm{MgCO}_{3}{ }^{\mathrm{a}}$ \\
\hline $\begin{array}{l}165 \mathrm{~A}-24-1,117-121 \mathrm{~cm} \\
\text { (host) }\end{array}$ & Vein. & $\begin{array}{l}\text { Range of composition with } \\
\text { median at } 1.5 \text { and mode at } \\
1.0^{+} \text {or } 1.5^{-} \text {. }\end{array}$ \\
\hline $166-29-3,83-90 \mathrm{~cm}$ & $\begin{array}{l}\text { Terminated crystals, coated by vermicular montmorillonite, in vugs in light reddish } \\
\text { brown calcite mass which encloses altered basaltic glass fragments. }\end{array}$ & 2.0 (range from 1.0 to 3.0 ) \\
\hline $167-94-3,78-84 \mathrm{~cm}$ & $\begin{array}{l}\text { "Dirty" calcite mass, with radial internal structure, embedded in large ovoid mass of } \\
\text { montmorillonite. }\end{array}$ & 0.5 \\
\hline $169-12-2,115-117 \mathrm{~cm}$ & $\begin{array}{l}\text { Dense system of anastomosing and cross-cutting calcite veins which enclose montmoril- } \\
\text { lonite lenses. }\end{array}$ & 0.5 or 1.0 \\
\hline $169-12-2,115-117 \mathrm{~cm}$ & Large colorless crystals in the same vein system as above. & 0.0 \\
\hline $171-27-2,75-86 \mathrm{~cm}$ & Calcite finely intergrown with montmorillonite in large irregular patches in basalt. & 4.0 \\
\hline $171-27-2,75-86 \mathrm{~cm}$ & $\begin{array}{l}\text { Colorless to white calcite, locally vuggy, in large irregular patches in basalt, with } \\
\text { admixed montmorillonite. }\end{array}$ & 2.5 \\
\hline $171-27-3,104-110 \mathrm{~cm}$ & $\begin{array}{l}\text { Light tan calcite-rich layer at lower contact of pillow; if the layer is altered glass, it } \\
\text { represents the outermost zone of the glassy selvage of the pillow. }\end{array}$ & 3.5 \\
\hline $171-27-3,104-110 \mathrm{~cm}$ & $\begin{array}{l}\text { Sparry calcite patch between the pillow and a large basalt clast in the sandy detrital } \\
\text { limestone below the pillow. }\end{array}$ & 3.5 \\
\hline
\end{tabular}

${ }^{\mathrm{a}} \mathrm{Mg}$ is assumed to be the only ion substituting for $\mathrm{Ca}$; the $\mathrm{MgCO}_{3}$ content is estimated from $\mathrm{d}_{(211)}$ and $\mathrm{d}_{(633)}$, measure relative to an internal silicon standard, according to the curve of Goldsmith et al. (1958).

rocks were not deeply buried and oxygen from bottom waters was more abundant and accessible. For the most part, the $\mathrm{Fe}, \mathrm{Mg}$, and $\mathrm{Al}$ appear to precipitate in the montmorillonite, so that the rocks approximate closed systems for these elements (contrast $\mathrm{Ca}$ ). However, the presence of montmorillonite in veins, amygdules, and patches of uncertain origin (altered chlorophaeite?) indicates that the rock is not entirely a closed system even to $\mathrm{Mg}, \mathrm{Fe}$, and $\mathrm{Al}$.

The interlayer cations are an entirely different matter. X-ray evidence indicates that Na-saturated and non-Nasaturated montmorillonites may be present, as well as intermediate types. The exchangeable positions in the non-Na-saturated types are presumably populated mainly by $\mathrm{Mg}$. The various montmorillonite types may correlate with various color and textural types of clay in the rocks, and there is some evidence that the montmorillonite in former pore spaces is more commonly Na-saturated than is the montmorillonite in pseudomorphs after primary phases. Presumably the constituent atoms of the pore-filling clays had relatively long residence times in $\mathrm{Na}$-bearing connate solutions compared to those atoms which simply migrated through intergranular fluid films to precipitate locally as the montmorillonite pseudomorphs after pyroxene, olivine, and other primary phases. These tentative observations need further testing, perhaps, by the electron microprobe which will permit each distinct type of montmorillonite to be separately analyzed.

The origin of the exchangeable $\mathrm{Na}$ in the montmorillonites is not certain. The plagioclase is largely fresh in montmorillonite-rich rocks, and the observed minor alteration selectively affected the Na-poor cores. Therefore, plagioclase contributes some, but not a great deal of $\mathrm{Na}$. The late interstitial residua appear to have been rich in $\mathrm{Fe}$ and $\mathrm{Ti}$, and, although $\mathrm{Na} / \mathrm{Ca}$ in them was undoubtedly high, it is not clear that they were Na-rich in absolute terms. Furthermore, they are quantitatively inadequate to supply $\mathrm{Na}$ to the abundant montmorillonite and were probably not a major source of the $\mathrm{Na}$. The largest source was probably the externally derived connate pore fluids which contributed $\mathrm{Na}$ and $\mathrm{K}$, both of which increase during alteration. $\mathrm{K}$ was probably preferentially incorporated into interlayer positions in montmorillonite, but was inadequate to saturate the clays (it came closest at Site 170 where the largest increases of $\mathrm{K}$ are observed). Therefore, the clays took up $\mathrm{Na}$ to the extent that it was available. In the smallest micropores and intergranular areas, diffusion was probably rate-controlling on the addition of $\mathrm{Na}$, so locally derived $\mathrm{Mg}$ 
TABLE 7

Sulfur Concentrations by Two Methods

\begin{tabular}{|c|c|c|}
\hline Sample & $\begin{array}{c}\text { X-ray } \\
\text { Fluorescence } \\
\%\end{array}$ & $\begin{array}{l}\text { LECO Automatic } \\
\text { Sulfur } \\
\text { Determinator } \\
(\mathrm{ppm})\end{array}$ \\
\hline $\begin{array}{l}164-28-1,87 \mathrm{~cm} \\
164-28-6,137 \mathrm{~cm}\end{array}$ & $\begin{array}{l}0.00 \\
0.02\end{array}$ & $\begin{array}{r}<10 \\
4.6\end{array}$ \\
\hline $\begin{array}{l}165 \mathrm{~A}-24-1,117-121 \mathrm{~cm} \\
\text { (host) }\end{array}$ & 0.34 & $3500 \pm 120$ \\
\hline $\begin{array}{l}165 \mathrm{~A}-24-1,117-121 \mathrm{~cm} \\
\text { (inclusion) }\end{array}$ & 0.06 & $451 \pm 129$ \\
\hline $165 \mathrm{~A}-26-2,80-84 \mathrm{~cm}$ & 0.29 & $2427 \pm 128$ \\
\hline $165 \mathrm{~A}-27-2,60-65 \mathrm{~cm}$ & 0.26 & $2187 \pm 96$ \\
\hline $\begin{array}{l}166-29-2,19-22 \mathrm{~cm} \\
166-29-3,72-74 \mathrm{~cm}\end{array}$ & $\begin{array}{l}0.01 \\
0.02\end{array}$ & $\begin{array}{l}45 \pm 19 \\
14 \pm 6\end{array}$ \\
\hline $\begin{array}{l}167-94-3,78-84 \mathrm{~cm} \\
167-95-2,40-43 \mathrm{~cm}\end{array}$ & $\begin{array}{l}0.08 \\
0.22\end{array}$ & $\begin{array}{r}880 \pm 55 \\
2420 \pm 96\end{array}$ \\
\hline $\begin{array}{l}169-5-1,21-24 \mathrm{~cm} \\
169-5-1,122-124 \mathrm{~cm} \\
169-6-3,33-38 \mathrm{~cm} \\
169-6-4,140-141 \mathrm{~cm} \\
169-12-1,31-32 \mathrm{~cm} \\
169-12-2,115-117 \mathrm{~cm}\end{array}$ & $\begin{array}{l}0.00 \\
0.13 \\
0.14 \\
0.11 \\
0.02 \\
0.01\end{array}$ & $\begin{aligned}<10 & \\
1053 & \pm 64 \\
1042 & \pm 43 \\
901 & \pm 27 \\
11 & \pm 4 \\
35 & \pm 22\end{aligned}$ \\
\hline $\begin{array}{l}170-10-\mathrm{CC} \\
170-16-1,17-19 \mathrm{~cm} \\
170-16-1,32-37 \mathrm{~cm} \\
170-16-1,32-37 \mathrm{~cm} \\
\text { (repeat) } \\
170-16-2,144-147 \mathrm{~cm}\end{array}$ & $\begin{array}{l}0.01 \\
0.01 \\
0.10 \\
0.08\end{array}$ & $\begin{aligned} 145 & \pm 28 \\
150 & \pm 14 \\
1104 & \pm 106 \\
1104 & \pm 106 \\
& \end{aligned}$ \\
\hline $\begin{array}{l}171-26-\mathrm{CC} \\
171-27-3,82-86 \mathrm{~cm} \\
171-33-\mathrm{CC}\end{array}$ & $\begin{array}{l}0.04 \\
0.04 \\
0.00\end{array}$ & $\begin{array}{l}122 \pm 20 \\
114 \pm 24 \\
<10\end{array}$ \\
\hline
\end{tabular}

NOTE:

$\mathrm{X}$-ray fluorescence values in weight percent, with an uncertainty of $\pm 0.02 \%$. LECO automatic sulfur determinator values in ppm; detection limit $10 \mathrm{ppm}$; uncertainties are standard deviations.

probably entered interlayer positions to extents dictated by the unavailability of $\mathrm{Na}$.

The uptake of $\mathrm{Na}$ indicated by the chemical analyses (Table 1 ) is remarkably large. In conjunction with the loss of $\mathrm{Ca}$, the $\mathrm{Na}$ gain leads to normative feldspar more sodic than $\mathrm{An}_{50}$ and, in norms calculated after adjustment of $\mathrm{Fe}$ so that $\mathrm{Fe}^{3+} /\left(\mathrm{Fe}^{3+}+\mathrm{Fe}^{2+}\right)=0.1$ (atomic), it leads to normative nepheline, even in subalkaline (tholeiitic) rocks. This surprising result led us to investigate the possibility that $\mathrm{NaCl}$ added by dessication of seawater or connate water in the microporous montmorillonite-rich rocks after coring is responsible for the large increment of $\mathrm{Na}$ over that in the presumed original rocks. The X-ray fluorescence values for $\mathrm{Cl}$ (Table 1) indicate that a salt source of $\mathrm{Na}$ is minor. However, we plan to investigate this matter further.

We cannot exclude the possibility that the rocks involved (especially those from Sites 164, 166, and 167 and the basement at Site 169) crystallized from magmas initially more oxidized than fresh ocean ridge basalts, in which case the adjustments of the analyses which lead to normative nepheline are unjustified. However, certain regularities indicate that diagenetic alteration is the prime cause of the undersaturation. For instance, where $\mathrm{CaO}$ and $\mathrm{Na}_{2} \mathrm{O}$ approach values typical of fresh ocean ridge basalts (the two deepest analyzed rocks from Site 169), virtually no normative nepheline appears. Where $\mathrm{CaO}$ remains "normal" and $\mathrm{Na}_{2} \mathrm{O}$ is increased (Site 164), normative nepheline is significant in subalkaline rocks. Where the increase of $\mathrm{Na}_{2} \mathrm{O}$ is coupled with a slight decrease of $\mathrm{CaO}$ (Site 166), normative nepheline is present but in much smaller amounts. Where the increased $\mathrm{Na}_{2} \mathrm{O}$ is coupled with even more radically reduced $\mathrm{CaO}$ (Site 167 , especially the deeper rock, and Site 171), normative nepheline does not appear at all. A special case is provided by the three deepest rocks at Site 170 where, despite radical reduction of $\mathrm{CaO}$, the gain of $\mathrm{Na}_{2} \mathrm{O}$ and $\mathrm{K}_{2} \mathrm{O}$ is so large that nepheline appears in the norms of the adjusted analyses. From this it appears that changes of $\mathrm{Na}$ and $\mathrm{Ca}$ "leapfrog", at least in part independently, during diagenesis so that their normative effects mutually compensate to unpredictable extents and necessitate that each rock be examined as an independent entity. The shallowest rock at Site 170, which has a much larger increase of $\mathrm{K}_{2} \mathrm{O}$ than of $\mathrm{Na}_{2} \mathrm{O}$, and the largest addition of total alkalis of any rock from that site, has no nepheline in its norm. This fact appears anomalous until one realizes that the $\mathrm{K}_{2} \mathrm{O}$ increase appears largely, not in the form of montmorillonite as in the deeper rocks, but as the highly siliceous, non-aluminous mineral celadonite. As a result, $\mathrm{SiO}_{2}$ is markedly increased and overcompensates the increase of alkalis.

The regularities in the norms outlined above depend critically on $\mathrm{CaO}$ because it appears both in diopside ( 48 to $55 \mathrm{wt} \% \mathrm{SiO}_{2}$, depending on $\mathrm{Fe} / \mathrm{Mg}$ ) and anorthite (43 wt \% $\mathrm{SiO}_{2}$ ). Therefore, as $\mathrm{CaO}$ is diminished without a corresponding reduction in $\mathrm{Al}_{2} \mathrm{O}_{3}, \mathrm{CaO}$ appears mainly in anorthite; $\mathrm{MgO}$ and $\mathrm{FeO}$, mainly in olivine (29 to 43 wt \% $\mathrm{SiO}_{2}$ ) rather than hypersthene (46 to 60 wt $\% \mathrm{SiO}_{2}$ ) or diopside. This leaves more $\mathrm{SiO}_{2}$ to saturate the nepheline that would otherwise appear as a result of the increased $\mathrm{Na}_{2} \mathrm{O}$.

Clearly, major element chemistry in subalkaline (tholeiitic) rocks is so radically affected by diagenesis that it must be used cautiously in interpreting deep-sea basalts, and is best used in conjunction with a knowledge of mineralogy. The alkaline rocks from Hole 165A and Sites 170 , and possibly 169 (the sill) are less susceptible than the subalkaline rocks to diagenetic alteration, in part due to the presence of hydrous minerals, so their analyses can be interpreted more directly. Nonetheless, even these rocks show some effects of diagenesis, and in cases where interpretations are less than compelling, diagenetic influences must be considered.

A tentative conclusion to be drawn from the rocks of Leg 17 , largely on the basis of negative evidence, is that diagenetic alteration is very slow in the absence of high $\mathrm{CO}_{2}$ activities. The deepest rocks at Hole 165 are highly zeolitized, despite the apparent low $\mathrm{CO}_{2}$ activity there, and might seem to pose an exception to this conclusion. Regardless, the shallower igneous rocks at Hole 165A are not zeolitized, and the zeolitization seems, therefore, to reflect a steep gradient of some physico-chemical condition. We suggest that the gradient was one primarily of temperature so that the alteration proceeded at temperatures elevated locally to values significantly higher than would 
have resulted from the undisturbed regional geothermal gradient. Therefore, the alteration is probably more properly viewed as zeolite-facies metamorphism rather than diagenesis, in the narrow sense, and is treated more fully in the discussion of Hole 165 .

\section{Original Rock and Magma Types}

In view of the discussion above, the nature of the original rocks must be inferred from evidence other than major element chemistry. A number of published studies over the past few years have empirically established a category of so-called refractory (i.e., alteration-resistant) minor and trace elements which preserve their primary concentrations and/or relative concentrations even in fairly highly altered rocks. The trace elements may exist in tiny refractory accessory mineral grains, but these have yet to be established with certainty. At present the elements are believed to reside mostly in various alteration-resistant major and minor phases ( $\mathrm{Sr}, \mathrm{Eu}$, and probably much of the $\mathrm{Ba}$ in plagioclase; $\mathrm{Zr}$, part of the $\mathrm{Ti}$, and most of the REE other than $\mathrm{Eu}$ in pyroxene; much of the $\mathrm{Ti}$ in opaque minerals; and $\mathrm{P}$ in apatite). Correlation plots of three pairs of refractory elements are shown in Figures 1, 2, and 3, in which are delineated, from published data, the fields populated by three groups of oceanic basalts. The minor components $\mathrm{TiO}_{2}$ and $\mathrm{P}_{2} \mathrm{O}_{5}$ prove to be particularly revealing.

The figures show quite clearly the alkaline nature of the hawaiites (and possibly one mugearite) from Hole 165, and the mugearite from Site 170, in accord with major element chemistry (Table 1) and mineralogy. This conclusion is strongly reinforced in the case of the mugearite from Site 170 by the $\mathrm{Ba}$ and REE pattern (Figure 4) which shows an enrichment of almost all elements over their concentrations in ocean ridge basalt and a strong preferential enrichment of the light REE and $\mathrm{Ba}$. The pattern resembles that of Hawaiian nepheline-melilite basalts.

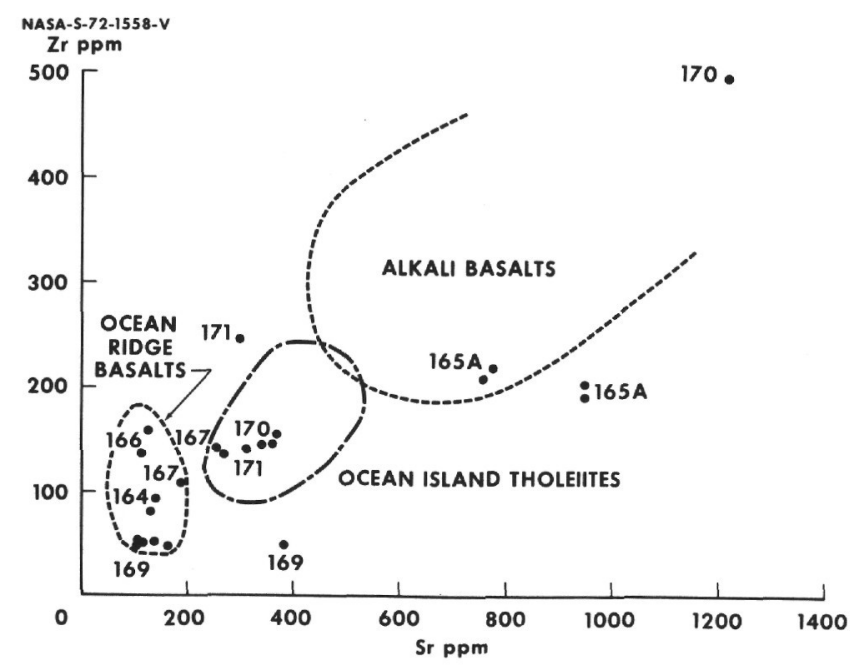

Figure 1. Correlation plot of X-ray fluorescence values of $\mathrm{Sr}$ and $\mathrm{Zr}$ (Table 1). The fields outlined for oceanic basalts of various types are based on published data.

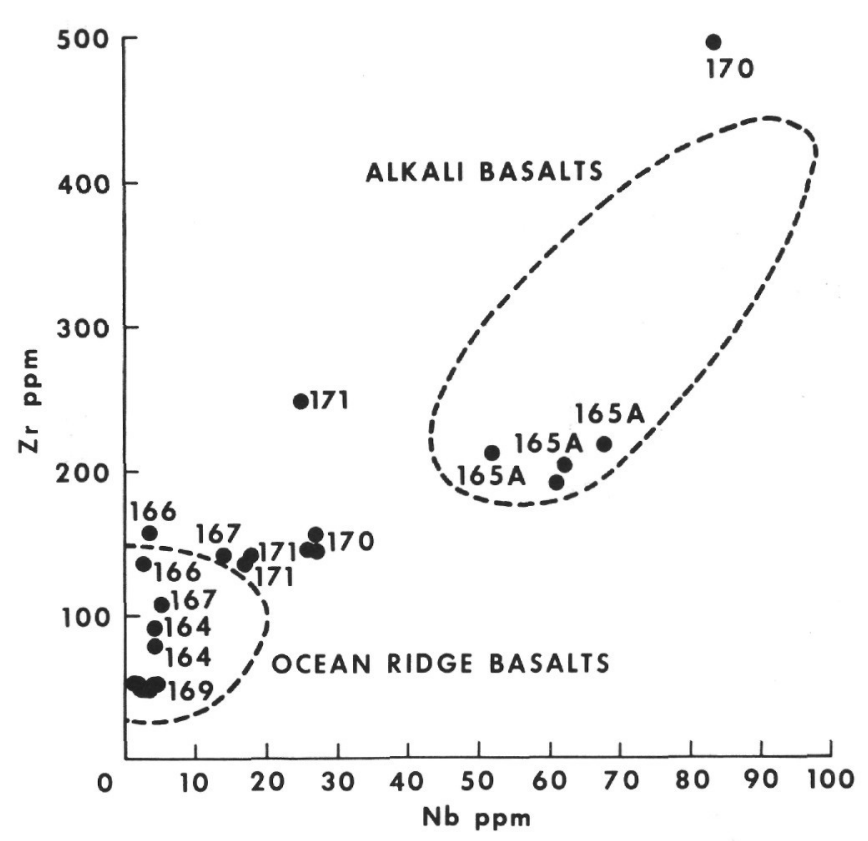

Figure 2. Correlation plot of X-ray fluorescence values of $\mathrm{Nb}$ and $\mathrm{Zr}$ (Table 1). The fields outlined for the two oceanic basalt types are based on published data which are inadequate to permit outlining a field for ocean island tholeiites as in Figures 1 and 3.

Similarly, the pillow basalts from Sites 164 and 166, and possibly from the basement at Site 169, appear to be ocean ridge basalts, in accord with petrographic indications. They were presumably extruded at the crest of the East Pacific Rise or its predecessor. The $\mathrm{Ba}$ and REE pattern of a sample from Site 164 (Figure 4) is flat, with a slight relative depletion of the light REE, as is typical of ocean ridge basalts. The minimum at Ce suggests mild seawater alteration. The pattern for the basement sample from Site 169 $(12-1,31-32 \mathrm{~cm})$ is similar but has a slight negative slope at the light REE end. The low concentrations in this sample suggest derivation of the magma from a trace elementdepleted source. The change of slope from the flat pattern typical of ocean ridge basalts is more difficult to explain. Extensive low-pressure fractional crystallization does not normally lead to a change of slope (Kay et al., 1970). The extreme degree of fractional crystallization required to effect the change would lead to changes of major element chemistry which are not observed; for instance, the resulting magma might no longer be basaltic. Furthermore, extensive fractionation, in conjunction with the observed low trace element concentrations, would imply improbably low concentrations in the initial basaltic liquid. The negative slope may be intrinsic to the magma source or a consequence of its partial melting if, as major element chemistry suggests, the rock is mildly alkaline transitional basalt rather than typical ocean ridge basalt. Or the negative slope may be more apparent than real. Careful examination shows that the effect is produced by a high Ce value alone, without which the pattern would be typically that of an ocean ridge basalt. A Ce anomaly of unknown cause seems to be the most logical explanation. 
The rocks from Site 167 appear to be ocean ridge basalts in many respects but with apparent tendencies in Figures 1, 2 , and 3 toward ocean island tholeiites. These rocks are very highly altered; so much so that the trace and minor elements plotted in the figures are perhaps no longer validly to be regarded as refractory. Pyroxene is largely replaced by montmorillonite, and those "refractory" elements normally diadochically dispersed in the pyroxene lattice may have been lost. If so, the original fresh rocks might have plotted even more than observed toward the fields of ocean island tholeiites, or possibly even in the field of mildly alkaline basalts. These apparent tendencies can be explained in terms of fractionation of an ocean ridge basalt, which would lead to higher trace element concentrations, as observed; and mineralogic evidence for such fractionation is to be seen in the early appearance of clinopyroxene in the rocks from Site 167. On the other hand, Site 167 is located on Magellan Rise, in which, if it is of volcanic constructional rather than tectonic origin, one might reasonably expect ocean island tholeiites or more alkaline rocks. Furthermore, the rocks are not pillow basalts of the type commonly found on the crests of oceanic ridges, and there is some evidence that the lower basalt unit cored at Site 167 may be a sill. Therefore, the original rocks at Site 167 were conceivably ocean island tholeiites, or transitional between them and ocean ridge basalts, or perhaps distinctly alkaline.

The rocks from Site 170 include the mugearite intercalated in the sediment section, and, at the deepest levels penetrated, a sill. Evidence for the sill is given in the discussion of the petrography of rocks from this site. The nature of the basement, therefore, is not accurately known. The site is in deep water, not far distant from a region with moderate bottom relief. The mugearite was recovered as a disoriented core catcher sample rather than as an intact core, and might represent angular clasts in a gravelly turbidite or fragments from a thin flow or sill sample in situ. In the latter case it is not easily argued that the highly differentiated mugearitic magma formed in a volcanic edifice, and the magma is more readily interpreted as emanating from the lower crust or mantle (compare arguments for Hole 165 below). The sill plots clearly in the field of ocean island tholeiites. However, it is highly altered, with only limited survival of pyroxene. Applying the same arguments as given above for rocks from Site 167, we cannot exclude the possibility that the sill was originally distinctly alkaline, as suggested by the $\mathrm{P}_{2} \mathrm{O}_{5}$ versus $\mathrm{TiO}_{2}$ plot. Therefore, in the sill, as in the mugearite, we have evidence of magmatic activity in a deep-water area of a type usually found in oceanic islands and island chains. Perhaps the oceanic crust is so "leaky" that such igneous rocks will be found widely distributed in deep-water areas of the oceans independent of the topography associated with seamounts and seamount chains. Macdougall (1971) presents evidence that isolated sills are one cause of the formation of abyssal hills. Isolated sills of alkaline rock might be viewed as abortive seamounts formed in areas of oceanic crust in which transient tectonic events were able to open temporary conduits but did not maintain them open long enough for the development of constructional bottom topography.

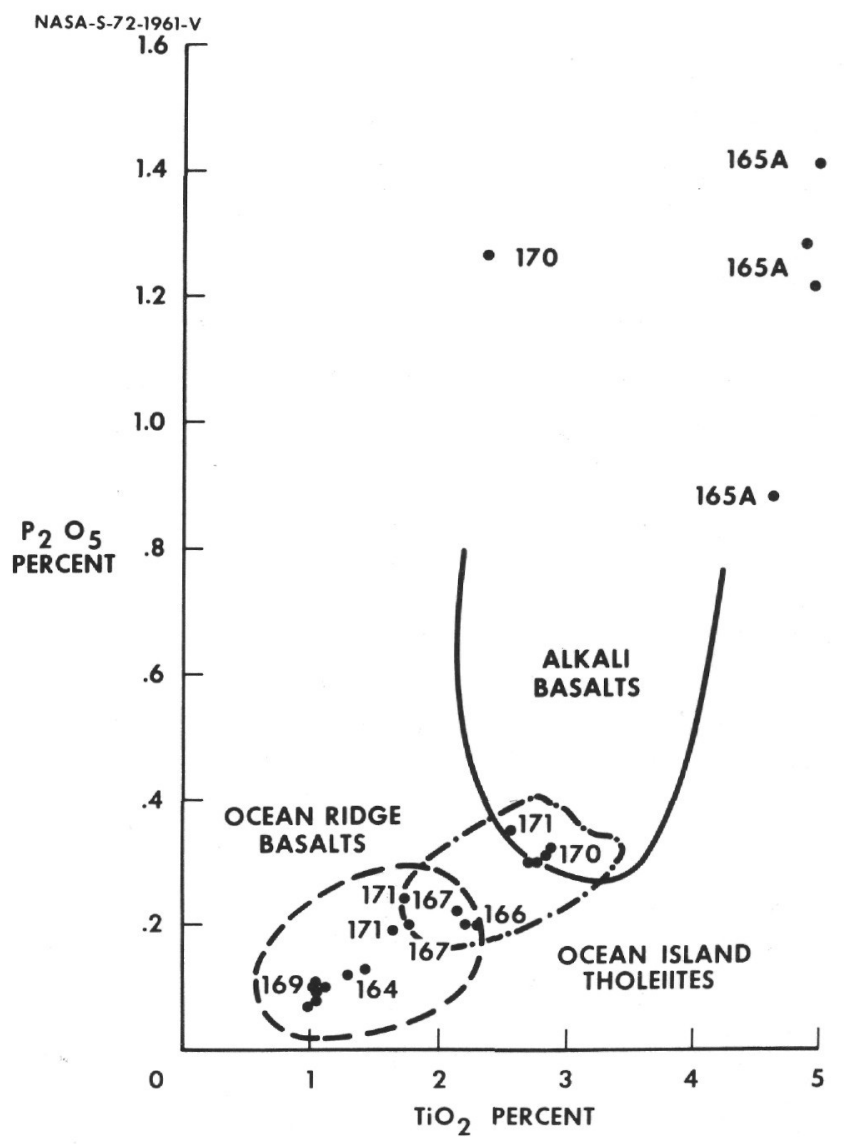

Figure 3. Correlation plot of X-ray fluorescence values of $\mathrm{TiO}_{2}$ and $\mathrm{P}_{2} \mathrm{O}_{5}$ (Table 1). The fields for various types of oceanic basalt outlined from published data define a narrow trajectory with relatively little scatter.

At Hole 165, differentiated alkaline rocks (hawaiites and possibly one mugearite) were sampled in situ in a deep-water area, but only $50 \mathrm{~km}$ from the nearest guyot in the Line Islands chain. Moore (1965) suggests that lavas from the reservoir under Kilauea can move more than $100 \mathrm{~km}$ down the east rift zone before eruption on the sea floor. One can offer a similar argument for Hole 165A (and the mugearite at Site 170?). However, there is no direct evidence that Hole 165 is on a possible rift zone ridge; if a Cretaceous ridge is present, but buried, it would show up in reflection profiles. Further, the possible Kilauea-derived lavas along the submarine part of the east rift zone are tholeiitic basalt, like the primitive lavas from which the exposed shield is constructed. The volume of hawaiitic differentiates in Hawaiian volcanoes is so small that it seems unlikely they would survive a 50 to $100 \mathrm{~km}$ journey along a rift zone without either congealing or mixing so much with other magmas as to lose their identities. Lastly, highly differentiated alkaline lavas are generally associated with calderas, satellitic vents, and other forms of central eruption, not with the construction of rift zone ridges; however, data are limited and rift zone ridges of dominantly alkaline oceanic volcanoes should be dredged. Collectively, the data do not exclude the possibility of direct magma mantle derivation of the hawaiites, as with the mugearite at Site 170 . 


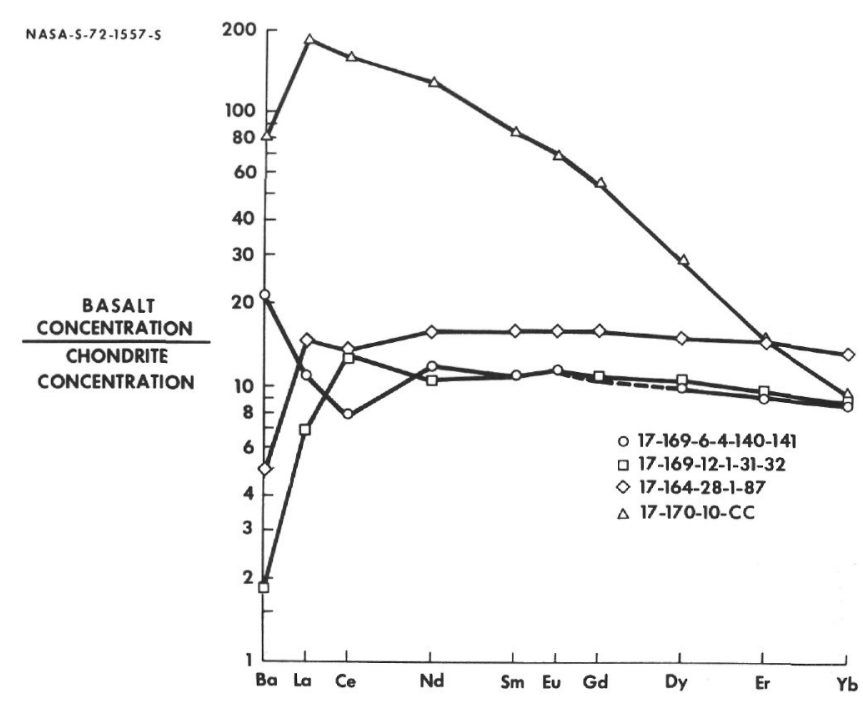

Figure 4. Chondrite-normalized patterns of REE (rare earth elements) and Ba for four selected rocks (Table 3). The pattern of 170-10-CC (mugearite) is similar to that of a Hawaiian nepheline-melilite basalt. Pillow basalt 164-28-1, $87 \mathrm{~cm}$, has the flat pattern with slight depletion of light REE typical of ocean ridge basalts; a slight negative Ce anomaly suggests seawater contamination. Pillow basalt 169-12-1,31-32 cm, has a similar pattern with a peculiar positive Ce anomaly of unknown origin. Diabase sill 169-6-4, 140-141 cm, has a similar pattern, but with less marked or no depletion of light $R E E$, and with strong negative $C e$ and positive $B a$ anomalies that suggest seawater contamination; the sill is complex and difficult to interpret in many respects (see text).

At Site 171, located in a saddle on Horizon Guyot, basalts were cored at two levels. The lower unit plots in the field of ocean island tholeiites, the upper, pillowed unit in either that field or the field of ocean ridge basalts. In an earlier statement, Bass et al. (1972) concluded that the upper, pillowed unit is in fact ocean ridge basalt. However, like the rocks from Sites 167 and 170, those from Site 171 are uniformly highly altered and, arguing as above, we might infer that the lower unit was distinctly alkaline, as suggested by the $\mathrm{P}_{2} \mathrm{O}_{5}$ versus $\mathrm{TiO}_{2}$ plot, and that the upper, pillowed unit was definitely ocean island tholeiitic, if not alkaline. Alternatively, and less likely, if the upper, pillowed unit is truly ocean ridge basalt, the only known "spreading center" to which to relate it would be a highly "leaky" ancestral Molokai Fracture Zone.

The sill cored at Site 169 is particularly puzzling. Its trace and minor elements place it clearly in the field of ocean ridge basalts and in the more trace element-depleted part of that field. Nonetheless, as elaborated in the discussion of the petrography of rocks from Site 169, the rocks are nepheline normative and strong arguments can be levied to the effect that the rocks truly have alkaline affinities. The suggestion is supported by the distinct negative slope of the $\mathrm{Ba}$ and REE pattern (Figure 4, 169-6-4, 140-141 cm), a slope even more pronounced than that of the pattern of the basement rock from Site 169. Contrary to the basement rock, however, the sill has a strong negative $\mathrm{Ce}$ anomaly suggestive of incorporation of seawater REE. The main problem is to explain the low absolute concentrations of the trace and minor elements. The sill provided the freshest igneous rocks recovered during Leg 17, so alteration is not the solution. If the sill is an ocean ridge basalt, there is no known spreading center, leaky fracture zone, interarc basin, or axis of extension of any sort to which to relate it.

In conclusion, let it be stressed that, although so-called refractory trace and minor elements are quite useful in characterizing altered as well as fresh oceanic basalts, the "altered" basalts on which these criteria were developed and tested (e.g., Hart and Nalwalk, 1970) were fairly fresh compared to the more highly altered rocks from Leg 17 . We may expect rocks with comparable and even greater degrees of alteration as the Deep Sea Drilling Project and dredging progress, and it is well to remember that "refractory" trace and minor element criteria for classifying rock types may yet be proven to fail in rocks so highly altered that pyroxene, the harbinger of many of these elements, does not survive. Evidently the alteration reduces the concentrations of trace elements and thus the apparent alkalinites of the rocks, driving them toward the fields of ocean ridge tholeiites in plots such as Figures 1, 2, and 3. In this sense, diagenetic alteration acts oppositely on trace and minor elements, on the one hand, and on alkalis on the other. As indicated above, alkalis increase during alteration and increase the apparent "alkalinities" of the rocks.

\section{Isotopic Relationships}

In Table 4 we present $\mathrm{Sr}$ and $\mathrm{Pb}$ isotopic data after normalization of $\mathrm{Sr}^{86} / \mathrm{Sr} 88$ to 0.1194 and correction of mass fractionation of $\mathrm{Pb}$. The table also gives the isotopic ratios after correction for apparent growth of radiogenic isotopes since emplacement of the parent magmas. Correction for an assumed age of 95 m.y., the approximate Early-Late Cretaceous boundary, is applied to all samples. In addition, a correction for an age of $65 \mathrm{~m} . \mathrm{y}$. is applied to 170-10-CC, the mugearite, in case it is a flow or sill of the same age as the sediments in which it is intercalated, rather than clasts in a turbidite from an older Cretaceous source. The corrections to the $\mathrm{Pb}$ isotopic ratios are based on the observed $\mu$ and $\kappa$ calculated from the $U$ and Th data in Table 3. The corrections to the Sr isotopic ratios, based on $\mathrm{Rb} / \mathrm{Sr}$ calculated from the X-ray fluorescence data in Table 1 , may be too large because of an increase of $\mathrm{Rb} / \mathrm{Sr}$ with time due to preferential addition of $\mathrm{Rb}$ during alteration. However, the correction is so small that the error does not affect any conclusion drawn below.

A $\mathrm{Sr}^{87} / \mathrm{Sr}^{86}$ value of 0.71020 was obtained during this study for the National Bureau of Standards $987 \mathrm{SrCO}_{3}$ standard. Most published data to date are referred to the Eimer and Amend standard. Subtracting the average $\mathrm{Sr}^{87} / \mathrm{Sr}^{86}$ difference between the two standards, obtained by a number of investigators (0.00221), from our value, we find that it corresponds to 0.7080 for the $\mathrm{E}$ and $\mathrm{A}$ standard, which is the value to which $\mathrm{Sr}$ isotopic ratios have been normalized in many recent published studies. In comparing our results with those from other studies, we therefore, refer in all cases to values normalized to $\mathrm{Sr} 87 / \mathrm{Sr} 86=0.7080$ for the $\mathrm{E}$ and $\mathrm{A}$ standard. 
The corrected $\mathrm{Sr}^{87} / \mathrm{Sr}^{86}$ values for the ocean ridge basalts from Site 164, the basement of Site 169 (12-1, $31-32 \mathrm{~cm}$ ), and the sill of uncertain petrologic affinities from Site $169(6-4,140-141 \mathrm{~cm})$ are comparable to or lower than values found for rocks of oceanic islands (Powell et al., 1965; Peterman and Hedge, 1971) and higher than the average (0.7026) found for ocean ridge basalts (Hedge and Peterman, 1970; Hart, 1971). The simplest and most likely interpretation is that these rocks (except possibly the sill) are ocean ridge basalts whose $\mathrm{Sr}$ is somewhat modified by seawater $\operatorname{Sr}(0.709)$ and to a lesser extent by secondary introduction of $\mathrm{Rb}$. The seawater $\mathrm{Sr}$ was probably introduced into the flows during alteration. The flow from Site 164 possibly acquired its slight negative $\mathrm{Ce}$ anomaly (Figure 4) at the same time. The sill, on the other hand, may have absorbed seawater during its primary crystallization (see discussion of Site 169).

The mugearite from Site 170 has a relatively low corrected $\mathrm{Sr}^{87} / \mathrm{Sr}^{86}$, comparable to or in the low part of the range of values for rocks from oceanic islands, especially those in which ocean island tholeiites and transitional basalts are known to occur (Powell et al., 1965; Peterman and Hedge, 1971). The mugearite is slightly to moderately altered and, if affected by seawater $\mathrm{Sr}$ was the ocean ridge basalts apparently were, would have a remarkably low initial $\mathrm{Sr}^{87} / \mathrm{Sr}^{86}$, the lowest known, in fact, for an alkaline rock of this type.

Isotopic data on $\mathrm{Pb}$ in Pacific volcanic rocks are sparse, so possible comparisons are limited. The $\mathrm{Pb}$ data from Table 4 are plotted, along with comparative data from other sources, in Figure 5 in which reference primary growth curves of $\mathrm{Pb}$ isotopes in chemically closed systems 4.55 b.y. old are shown for the present-day values of $\mu(=$ $\left.\mathrm{U}^{238} / \mathrm{Pb}^{204}\right)$ and $\kappa\left(=\mathrm{Th}^{232} / \mathrm{U}^{238}\right)$ indicated; the assumed initial $\mathrm{Pb}$ isotope ratios ( $\mathrm{Pb}$ in meteoritic troilite) are: $\mathrm{Pb}^{206} / \mathrm{Pb}^{204}=9.346 ; \mathrm{Pb}^{207} / \mathrm{Pb}^{204}=10.218 ;$ and $\mathrm{Pb}^{208} / \mathrm{Pb}^{204}=28.96$.

In Figure 5 we see that the ocean ridge pillow basalt from the basement at Site 169 is from a source region with slightly higher $\mu$ and $\kappa$ than those from which Hawaiian basalts (Tatsumoto, 1966a) and ocean ridge basalts from the East Pacific Rise (Tatsumoto, 1966b) and Juan de Fuca and Gorda ridges (Church, unpublished data) were derived.

The $\mathrm{Pb}$ from the sill at Site 169 is highly radiogenic, especially in $\mathrm{Pb}^{2} 06 / \mathrm{Pb}^{204}$, and indicates a multistage $\mathrm{Pb}$ which evolved in a high- $\mu$ environment within about the last 1.5 b.y. If the sill is a primitive, mantle-derived tholeiite (which is highly uncertain; see discussion of Site 169), and its $\mathrm{Pb}$ is uncontaminated, the $\mu$ value, slightly greater than 9.1, would be among the highest reported for a rock of tholeiitic chemistry. Two alternative explanations which must be considered are (a) that the rock is alkaline, for which there is evidence, and the radiogenic $\mathrm{Pb}$ is an intrinsic property of this and other mantle-derived alkaline rocks, and (b) that the rock is either tholeiitic or alkaline, and the primary $\mathrm{Pb}$ was contaminated by absorption of seawater or sediments during emplacement and primary crystallization. Oceanic rocks with isotopically similar $\mathrm{Pb}$ are known from Iwo Jima (trachyandesite; Tatsumoto, 1966a), Easter Island (Tatsumoto, 1966b), Ascension Island (Gast et al., 1964; Gast, 1969) and the Canary Islands (Oversby and Gast,

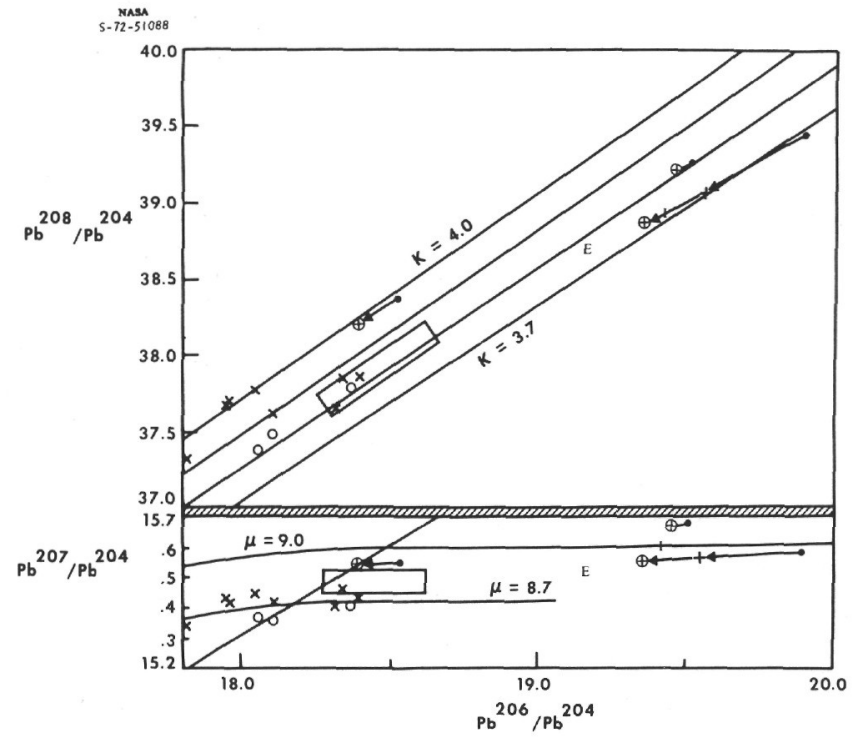

Figure 5. Plots of $\mathrm{Pb}^{206} / \mathrm{Pb}^{204}$ versus $\mathrm{Pb}^{207} / \mathrm{Pb}^{204}$ and $\mathrm{Pb}^{206} / \mathrm{Pb}^{204}$ versus $\mathrm{Pb}^{208} / \mathrm{Pb}^{204}$ (Table 4) for the rocks shown in Figure 4, plus reference data on Hawaiian volcanic rocks ( $x$; Tatsumoto, 1966a), ocean ridge basalts from the East Pacific Rise 10; Tatsumoto, 1966b), and ocean ridge basalts from the Juan de Fuca and Gorda ridges (fields enclosed in boxes; Church, unpublished data). Large solid dots are observed isotope ratios; crosses are ratios corrected for growth of radiogenic isotopes in the last 65 m.y.; and circled crosses are ratios corrected to 95 m.y. (see Table 4). Primary growth curves are given for $\mathrm{Pb}$ 's evolved in chemically closed systems 4.55 b.y. old (initial meteoritic troilite $\mathrm{Pb}$ ) for present day values of $\mu=8.7$ and 9.0 in the lower plot, and for present day values of $\mathrm{K}=3.7,3.8$, 3.9 and 4.0 ( $\mu=8.9$ in all cases) in the upper plot. The positively sloping straight line in the lower plot is the Geochron, i.e., the locus of all $\mathrm{Pb}$ 's which grew coetaneously in chemically closed systems of all possible $\mu$ values for the last 4.55 b.y., starting from meteoritic troilite $\mathrm{Pb}$.

1970). The Iwo Jima rocks are alkaline. The others are suites in which the basaltic members are transitional with alkaline affinities (see below). Gast et al. (1964) present cogent arguments against contamination as a cause of the $\mathrm{Pb}$ isotopic features of the Ascension Island rocks and conclude that they and their radiogenic $\mathrm{Pb}$ stem from a mantle source. Tatsumoto's data rule out contamination as a cause of radiogenic $\mathrm{Pb}$ in the Easter Island rocks, and, while he presents isotopic evidence that they may be derived by differentiation of ocean ridge basalt, he also points out that the data do not rule out derivation directly from a mantle source as a viable alternative. Thus, the sill at Site 169 may be an alkaline rock from a mantle source characterized by radiogenic $\mathrm{Pb}$. If we accept this, then we must entertain the possibility that the radiogenic $\mathrm{Sr}$ in the pillow basalt from the basement at this site is not a product of seawater contamination but a radiogenic mantle $\mathrm{Sr}$ that coexists with the radiogenic $\mathrm{Pb}$. 
On the other hand, as discussed above and in the section on the petrography of Site 169 , the Ce, Ba, and mineral distribution in the sill strongly suggest seawater contamination during emplacement and primary crystallization. The somewhat radiogenic Sr may be due to this contamination if its primary $\mathrm{Sr}$ was as "primitive" as that of ocean ridge basalts (0.7026), and a similar argument must be entertained for the radiogenic $\mathrm{Pb}$. Contamination by the sedimentary Pb's of Chow and Patterson $(1959,1962)$ would have raised $\mathrm{Pb}^{207} / \mathrm{Pb}^{204}$, as observed, but would have lowered $\mathrm{Pb}^{206} / \mathrm{Pb}^{2} 04$ and $\mathrm{Pb}^{208} / \mathrm{Pb}^{204}$, opposite to the observed increases (assuming that the initial radios were not high as in the Pb's of St. Helena and Guadalupe; Gast, 1969; Oversby and Gast, 1970; Tatsumoto, 1966b). Tatsumoto (1969) proposes a crustal contamination model that can account for the $\mathrm{Pb}$ in andesites and island arc tholeiites of Japan, but the $\mathrm{Pb}$ 's concerned are much lower in $\mathrm{Pb}^{206} / \mathrm{Pb}^{204}$ and, except in one case, much lower in $\mathrm{Pb}^{208} / \mathrm{Pb}^{204}$ than the $\mathrm{Pb}$ from the sill at Site 169 . Clearly, no currently known crustal, seawater, or sediment contaminant can plausibly account for the $\mathrm{Pb}$ in the sill, but we must await $\mathrm{Pb}$ isotope analyses of the overlying and underlying sediments before this explanation can finally be rejected.

The mugearite from Site 170, like the sill from Site 169, contains $\mathrm{Pb}$ with an unusually high $\mathrm{Pb}^{206} / \mathrm{Pb}^{204}$, again similar to that in the Iwo Jima trachyandesite and in the Easter, Ascension, and Canary islands suites. In addition, the $\mathrm{Sr}^{87} / \mathrm{Sr}^{86}$ of the mugearite is quite low for an alkaline rock, in this respect again matching the Ascension Island rocks (Peterman and Hedge, 1971). Its Sr similarly matches those of two Easter Island rocks called tholeiite and basaltic andesite by Hedge and Peterman (1970), who refer (Peterman and Hedge, 1971) to Bandy (1937) for the chemical basis for these names. Tatsumoto (1966b) likewise refers to "tholeiite with alkali basalt affinity" from Easter Island. However, although Bandy (1937) repeatedly identifies pigeonite in Easter Island rocks, on the basis of 2V's smaller than $25^{\circ}$, his descriptions are clearly not those of a tholeiitic suite, nor does he cite the analysis of any rock which can be called a tholeiite. Discounting high Ti or another chemical cause for the low $2 \mathrm{~V}$ 's and disregarding the report that some of the pigeonites are distinctly pleochroic (Bandy, 1937, p. 1597), we nonetheless note that they occur in rocks that invariably contain unresorbed groundmass olivine and have high alkali contents, high alkali to silica ratios, and high $\mathrm{TiO}_{2}$ contents. Thus, although the basic members of the suite are not strongly alkaline, they appear to be transitional basalts with alkaline affinities. As elaborated by Coombs (1963), the more fractionated basic members of such suites may contain pigeonite, although rarely, and the suites typically yield pantelleritic (peralkaline rhyolitic) derivatives. In fact, the Easter Island suite was one of Coombs' type cases for this type of laval. Similarly, the long known granitic inclusions in the lavas of Ascension Island are probably intrusive equivalents of acid derivatives with peralkaline tendencies (Tilley, 1950), and the widely distributed, abundant acid fractionation products of the Canary Islands have strong peralkaline tendencies and in some cases achieve peralkalinity. Thus, in terms of both radiogenic $\mathrm{Pb}$ and low
$\mathrm{Sr}^{87} / \mathrm{Sr}^{86}$, the closest matches for the Site 170 mugearite are among suites of rocks derived from transitional basalts with alkaline affinity.

As discussed above, contamination is not the source of the radiogenic $\mathrm{Pb}$ in the Ascension and Easter islands rocks, and, while contamination with seawater $\mathrm{Sr}$ cannot be ruled out in the case of the moderately altered mugearite, such contamination is much less likely in the subaerial flows of Ascension and Easter islands. We conclude, therefore, that the isotopic features of the $\mathrm{Pb}$ and $\mathrm{Sr}$ in all these rocks are inherited from mantle source regions with similar multistage fractionation histories.

$\mathrm{The} \mathrm{Pb}$ isotopes in the mugearite lie on a primary growth curve with $\mu=8.9$ and on an isochron with a negative model age of several hundred million years. $\mathrm{Pb}$ isotopes from a Hawaiian rock of similar chemistry lie on a primary growth curve with $\mu$ only slightly lower (8.7), but are much less radiogenic and lie very nearly on the $0 \mathrm{~m} . \mathrm{y}$. isochron. Thus, Hawaiian $\mathrm{Pb}$ is distinctly different from that at Site 170 and much more closely resembles the Pb's from ocean ridge basalts.

A comparison of the mugearite $\mathrm{Pb}$ with that from rocks from nearby Site 169 reveals similarities and contrasts. The $\mu$ of the $\mathrm{Pb}$ from the basement flow nearly equals that of the mugearite $\mathrm{Pb}$; the model age of the $\mathrm{Pb}$ from the sill does not equal that of the mugearite $\mathrm{Pb}$, but has a similarly large negative value. Arguments can be marshalled both for and against a homogeneous mantle (as regards $\mu$ values) in this region of the Pacific if one assumes that all rocks concerned stem from the same source region in the upper mantle. However, one rock from Site 169 is definitely from a sill, the lower rock at Site 170 is probably from a sill, and the upper rock at Site 170 may be from a flow or sill. Only the basement at Site 169 is probably oceanic crust formed at a spreading center (the East Pacific Rise). Hence, the four igneous units at Site 169 and 170 may have four separate ages, and, if the lithosphere is decoupled in its motions from the underlying upper mantle sources of these magmas, no two need stem from the same mantle source.

Regardless, meaningful comparisons and tectonic conclusions from the isotopic data can be made. As indicated above, the $\mathrm{Pb}$ 's from the sill at Site 169 and from the mugearite at Site 170 are most closely matched by $\mathrm{Pb}$ 's from the Iwo Jima trachyandesite and the transitional basalt suites from Ascension, Easter, and the Canary islands. The similarities are independent of geography (Atlantic versus Pacific) and tectonic setting (island arc, oceanic islands near but not at the crest of a spreading ridge, and oceanic islands near a continental edge and far removed from a ridge crest). On reexamining the $\mathrm{Pb}$ isotope data discussed above and the even more radiogenic Pb's from highly alkaline suites like those of St. Helena (Gast, 1969; Oversby and Gast, 1970) and Guadalupe (Tatsumoto, 1966b), orderly groupings appear. Pb's are increasingly radiogenic in the following sequence: ocean ridge basalts, which are relatively tholeiitic; basalts from ocean islands near ridge crests, which are generally transitional basalts with alkaline affinities and give rise to pantelleritic derivatives (Bass, 1972); and basalts from ocean islands well removed from ridge crests, which are generally alkaline and give rise to trachytic and phonolitic derivatives (St. Helena 
and Guadalupe). Thus, $\mathrm{Pb}$ isotopic variations parallel the chemical variations pointed out by McBirney and Gass (1967). Both would seem to be due to tapping progressively deeper magma sources at the base of a lithosphere which thickens progressively away from a ridge crest. Most of the changes take place within the first several hundred kilometers from the crest, beyond which the thickening of the lithosphere is slow. The variations suggest that, at least as regards $\mathrm{Pb}$ isotopes, the upper mantle is horizontally layered.

The depths from which magmas are tapped near a ridge crest appear to vary with spreading rate (deeper for slower rates; Bass, 1971); Thus, for islands equally near ridge crests, the one on the more slowly spreading ridge should have more alkaline rocks, which in turn should have more radiogenic $\mathrm{Pb}$. Ascension and Easter islands are at comparable distances from the crests of the slow-spreading Mid-Atlantic Ridge and fast-spreading East Pacific Rise, respectively, and the somewhat more radiogenic $\mathrm{Pb}$ 's from Ascension Island (Tatsumoto, 1966b) thus agree with the prediction.

The relatively nonradiogenic $\mathrm{Pb}$ 's from Gough and Tristan da Cunha in the South Atlantic (Gast et al., 1964; Oversby and Gast, 1970) are from islands removed from the crest of the Mid-Atlantic ridge and would appear to pose exceptions to the above generalization. We suggest that these $\mathrm{Pb}$ 's may reflect regional variations in the upper mantle and that, given $\mathrm{Pb}$ 's may reflect regional variations in the upper mantle and that, given $\mathrm{Pb}$ 's from ridge basalts and from island basalts collected at various distances from the ridge crest in this region, their relative isotope ratios would show the same pattern found above but displaced toward lower absolute values.

Hawaiian $\mathrm{Pb}$ 's seem to be another exception. However, the Hawaiian chain is special in many respects, including its large size and the presence of the most voluminous ocean island tholeiites known anywhere, and we suggest that the tectonic circumstances controlling the Hawaiian chain lead to eruption of magmas from a "depleted" mantle source which, at least as regards $\mathrm{Pb}$, is isotopically similar to that which supplies ocean ridge basalts.

Green (1971) proposes a horizontally layered upper mantle model in which the layer from which ocean ridge basalts are tapped is actually the deepest layer involved in oceanic volcanism, namely the "depleted" lower part of the low velocity layer. By virtue of the mechanics of spreading at a ridge crest, it is brought to the surface to yield the ridge basalts. He derives the Hawaiian magmas, including the ocean island tholeiites, from the next shallower layer, namely the upper part of the low velocity layer which has been "enriched" in those incompatible elements depleted from the lower part of the low velocity layer. However, he also would implicitly derive the highly radiogenic alkaline suites of other oceanic islands from the same layer. This is not possible without further assumptions, such as contamination, to account for the differences between their $\mathrm{Pb}$ 's and those of the Hawaiian magmas. We would modify his model as follows. The mechanics of formation of the Hawaiian chain involves enough "spreading" of the underlying lithospheric fractures to permit tapping of magmas from a deep, relatively nonradiogenic layer nearly, but not quite, as deep as that from which ocean ridge basalts are tapped. Isolated volcanoes and those in small chains, in the construction of which "spreading" is not pronounced, tap magma from the shallower, radiogenic layer as in Green's model.

As a final note we stress that the correlations described above fail as regards Sr (Peterman and Hedge, 1971). For instance, the relatively radiogenic $\mathrm{Pb}$ 's of $\mathrm{St}$. Helena and Gudalupe are coupled with relatively nonradiogenic Sr, and just the opposite for Tristan da Cunha and Gough. A completely general model must evidently include both vertical and horizontal variations in the upper mantle and different fractionation mechanisms for the elements, both parent and daughter, involved in the $\mathrm{Pb}$ and $\mathrm{Sr}$ isotope systems.

\section{SUMMARY}

Igneous rocks cored at seven sites during Leg 17 include flows, pillows, and sills. Additional volcanic material appears at each site as hyaloclastites, turbidites rich in volcanic detritus, and pyroclastic and wind-borne detritus in pelagic sediments. These sedimentary components generally record volcanism that postdates plate formation at the crest of the East Pacific Rise and, in the case of Horizon Guyot (Site 171), volcanism and erosion in the latter stages of construction of a large oceanic volcano, including the time during which its top was emergent.

Analyses by many methods of the sills, flows, and pillows yielded detailed information on structure, texture, primary and deuteric mineralogy, secondary mineralogy due to seawater alteration and diagenesis, chemistry (major, minor and trace elements, including rare earths, $\mathrm{U}$, Th and $\mathrm{Pb})$, and isotopic relations ( $\mathrm{U}, \mathrm{Th}, \mathrm{Pb}$, and $\mathrm{Sr}$ ).

The foremost problem encountered in interpreting the rocks arises from changes attendant on the ubiquitous diagenetic alteration. The alteration was especially promoted by high $\mathrm{CO}_{2}$ activity, coarse grain size, and topographic relief which, in Magellan Rise (Site 167) and Horizon Guyot (Site 171), evidently facilitated fluid circulation. Elevated temperature accelerated alteration and led to distinct minerals (such as mixed-layer chloritemontmorillonite) which did not appear to result from low temperature diagenesis; however, elevated temperatures evidently were local and short lived. Fracturing favored alteration, but only in conjunction with one or more of the above factors. Of these factors, the most important was $\mathrm{CO}_{2}$ activity, which probably was controlled by the abundance of carbonate in the sediment section. Alteration was very slow under conditions of low temperature and low $\mathrm{CO}_{2}$ activity. Under conditions of high $\mathrm{CO}_{2}$ activity, plagioclase reacted slowly, but olivine and interstitial mesostases, and finally even clinopyroxene, were converted to montmorillonite.

The largest changes in major and minor element chemistry involve gain of $\mathrm{H}_{2} \mathrm{O}, \mathrm{K}$, and $\mathrm{Na}$; loss of $\mathrm{Ca}$; and oxidation of $\mathrm{Fe}$. Oxidation is extensive but incomplete because most alteration occurred after burial, when access to oxygen was limited. $\mathrm{K}$ was preferentially added in exchangeable surface and interlayer sites in montmorillonite, but it was available in limited supply, and $\mathrm{Na}$ now dominates in these sites. $\mathrm{Ca}$, released mainly from 
clinopyroxene during alteration, migrated to vesicles, joints, and interpillow and interflow spaces where it was precipitated as Mg-poor calcite. Analyzed samples were chosen to avoid megascopic calcite. The analyses yield norms with variable amounts of "anomalous" nepheline due to gain of $\mathrm{Na}$; $\mathrm{Ca}$ loss may compensate the effect of $\mathrm{Na}$ gain, but to an unpredictable extent because the gains and losses of $\mathrm{Na}$ and $\mathrm{Ca}$ are largely independent. The usual net effect, however, is to increase the apparent "alkalinity". These changes obviate major element chemistry as a reliable guide to original rock and magma type in altered basic rocks.

Minor and trace elements, especially "refractory" (i.e., alteration resistant) elements serve somewhat better, but, since many of these elements are located in clinopyroxene, even these are lost in highly altered rocks in which clinopyroxene is destroyed. Contrary to the changes in major and minor elements, the losses of trace elements lead to a reduction of apparent "alkalinity".

Integration of the varied results, always with the obscuring effects of alteration in mind, yields the following conclusions regarding the igneous rocks and the immediately overlying sedimentary rocks:

Site 164: Brown montmorillonitic clays with relict volcanic components overlie pillowed ocean ridge basalts which represent the top of Layer 2 of the oceanic crust formed at the crest of the East Pacific Rise.

Site 165A: A volcanic archipelagic sedimentary apron, shed westward from the Line Islands chain, overlies a group of strongly differentiated alkaline flows or shallow intrusions (hawaiites and possibly one mugearite) probably related to the Line Island rocks. The group lacks local topographic expression as a seamount and was probably erupted directly from the mantle. It is probably not true basement (Layer 2), but was emplaced some distance from the crest of the East Pacific Rise and overlies a section of older sedimentary rocks. Zeolite facies metamorphism under conditions of short-lived, slightly elevated temperature and low $\mathrm{CO}_{2}$ activity led to replacement of plagioclase by zeolites (mainly chabazite and gmelinite) in the lowest rocks penetrated; pyroxene survives. The heat source was probably a local intrusion.

Site 166: Volcanogenic sediments overlie $\mathrm{Fe}$ - and Mn-charged marly mudstones which rest on pillowed and nonpillowed ocean ridge basalts that probably represent the top of crustal Layer 2 formed at the crest of the East Pacific Rise.

Site 167 (Magellan Rise): A carbonate plus chert section with little volcanic admixture overlies a section of flows and possible sills which are cut by tectonic breccia zones. Trace element chemistry suggests ocean ridge tholeiites, but the intense alteration and possible loss of trace elements leave open the possibility that the rocks are ocean island tholeiites or mildly alkaline basalts erupted during the volcanic construction of Magellan Rise, a broad volcanic edifice which evidently failed to reach sea level. An older sediment section may exist at depth beneath this edifice. The breccia zones served as conduits for hydrothermal solutions during the volcanic activity.

Site 169: The upper sediments are brown clays with porcellanitic chert beds. Cenomanian or Turonian beds in the lower part of these clays are intruded by a deuterically altered, but otherwise fairly fresh diabase sill. Still lower there are, in turn, chalk free of volcanic components, brown zeolitic clay, and the basement (Layer 2) composed of pillowed ocean ridge basalt. Both flows and sill are very low in trace elements, but in many other ways the sill appears to be alkaline. This problem is unresolved. If the sill is an ocean ridge basalt, it is unrelated to any currently known spreading center [The basement rocks are chemically so different from those currently erupted at the crest of the East Pacific Rise that one may question whether they truly represent Layer 2.]. Diagenetic $\mathrm{K}$-feldspar from the upper contact of the sill gives a $\mathrm{K}-\mathrm{Ar}$ age of $58 \pm 2 \mathrm{~m} . \mathrm{y}$., so the age is probably late Cretaceous.

Site 170: A sediment section of brown clay, mudstone, and sandstone, all with moderate to abundant volcanic components, includes a mugearite-bearing horizon and overlies a highly altered sill of ocean island tholeiite or alkali basalt at the bottom of the hole. Deeper sediments and oceanic crust were not penetrated. The mugearite, found as fragments in a core catcher sample, may represent a flow, sill, or clasts in a gravelly turbidite. The ocean floor at this site is not a seamount, so, if the mugearite is a flow or sill, it indicates derivation of highly differentiated magmas of this type directly from the mantle. Unlike the zeolitized hawaiites with fresh pyroxene at Hole $165 \mathrm{~A}$, the mugearite contains fresh plagioclase, moderate amounts of montmorillonite, and no pyroxene; it appears to have suffered its moderate alteration under conditions of high $\mathrm{CO}_{2}$ activity. The sill beautifully displays diffusioncontrolled diagenetic alteration fronts of various types.

Site 171 (Horizon Guyot): At this site, located in a saddle on Horizon Guyot, the sediment section is largely calcareous with much volcanic detritus and, in an intermediate part of the section, includes intercalations of volcanic sediments and a pillow basalt with numerous pseudomorphs after phenocrysts and microphenocrysts of olivine. The volcanic debris was probably eroded and slumped from shoal and emergent parts of the adjacent cones on this compound guyot. The sedimentary rocks overlie a porphyritic olivine basalt cored at the bottom of the hole. Trace elements indicate that the porphyritic basalt at the bottom is an ocean island tholeiite (or an alkali basalt), and that the pillow basalt higher in the section is either an ocean ridge basalt or an ocean island tholeiite. An ocean ridge basalt might be related to a "leaky" ancestral Molokai Fraction Zone. However, both basalts are intensely altered, with destruction of most pyroxene and probably loss of trace elements. Originally both rocks were probably normal ocean island lavas much more alkaline than the trace elements presently indicate, and neither is an ocean ridge basalt.

Deformational features are varied and reflect the tectonic histories of the rocks in subtle but meaningful ways. The ocean ridge basalts from Sites 164 and 166 and the basement of Site 169, for instance, underwent the processes attendant on spreading of nascent oceanic crust at a ridge crest and are now fractured and veined due both to cooling and tectonic stresses. Flows and sills emplaced on, or in sediments away from, both the ridge crest and seamounts (hawaiites of Hole 165A, the diabase at Site 
169, and the lower unit at Site 170) are, except at their contacts, largely unfractured and unveined; diffusioncontrolled alteration "fronts" in such rocks tend to parallel their contacts. Flows, and perhaps sills, emplaced during construction of seamounts commonly show fractures and veins related to cooling stresses and, perhaps, slumping of unstable slopes and may, in addition, show discrete tectonic breccia zones (Site 167) and weak alteration related to movement of hydrothermal solutions along such zones (Site 167 and less so at Site 171).

Conclusions to be drawn from observed and agecorrected $\mathrm{Sr} 87 / \mathrm{Sr} 86$ are limited by the generally unknown extent to which seawater $\mathrm{Sr}$ was added during diagenesis and seawater alteration. However, $\mathrm{Pb}$ isotope ratios on rocks from Sites 169 and 170, when compared with those in the literature, yield a generalization sufficiently striking to merit further testing. $\mathrm{Pb}$ 's become more radiogenic in the sequence: ocean ridge basalt (such as basement flows at Site 169); ocean island transitional basalts with alkaline affinities (and pantelleritic differentiation products) erupted near ridge crests (possibly including the sill at Site 169 and the mugearite at Site 170); and ocean island alkalic basalts (with trachytic to phonolitic differentiation products) erupted on ridge flanks (such as the suites of St. Helena and Guadalupe). These variations may reflect partial melts tapped from horizontal, isotopically distinct layers at different depths in the upper mantle as a result of varying tectonic stress and strain patterns and lithospheric thicknesses at and away from ridge crests. Regional horizontal gradients may lead to different absolute ratios for given rock types (such as the relatively nonradiogenic Pb's in the alkaline suites of Gough and Tristan da Cunha), but imputatively in the order cited above from one rock type to another.

\section{REFERENCES}

Bandy, M. C., 1937. Geology and petrology of Easter Island: Geol. Soc. Am. Bull., v. 48, p. 1589.

Bass, M. N., 1971. Variable abyssal basalt populations and their relation to sea-floor spreading rates: Earth Plan Sci. Lett. v. 11, p. 18 .

, 1972. Occurrence of transitional abyssal basalt. Lithos v. 5, p. 57.

Bass, M. N., Rhodes, J. M., and Shih, C., 1972. Chemistry and diagenesis of DSDP Leg 17 basalts: Am. Geophys. Union Trans. 53, p. 546.

Buddington, A. F. and Lindsley, D. H., 1964. Iron-titanium oxide minerals and synthetic equivalents: J. Petrol. v. 5, p. 310 .

Catanzaro, E. J., 1967. Absolute isotopic abundance ratios of three common lead reference samples: Earth Plan. Sci. Lett. v. 3, p. 343.

Chow, T. J. and Patterson, C. C., 1959. Lead isotopes in manganese nodules: Geochim. Cosmochim. Acta, v. 17, p. 21 .

, 1962. The occurrence and significance of lead isotopes in pelagic sediments: Geochim. Cosmochim. Acta, v. 26, p. 263.

Coombs, D. S., 1963. Trends and affinities of basaltic magmas and pyroxenes as illustrated on the diopsideolivine-silica diagram: Min. Soc. Am. Spec. Paper, v. 1, p. 227.
Epstein, S., Buchsbaum, R., Lowenstam, H. A., and Urey, H. C., 1953. Revised carbonate-water isotopic temperature scale: Geol. Soc. Am. Bull., v. 64, p. 1315.

Gast, P. W., 1969. The isotopic composition of leads from St. Helena and Ascension Islands: Earth Plan. Sci. Lett. v. 5, p. 353 .

Gast, P. W., Hubbard, N. J. and Wiesmann, H., 1970. Chemical composition and petrogenesis of basalts from Tranquillity Base: Geochim. Cosmochim. Acta, v. 34, Suppl. 1, Apollo 11 Lunar Sci. Conf. Proc., v. 2, p. 1143.

Gast, P. W., Tilton, G. R., and Hedge, C., 1964. Isotopic composition of lead and strontium from Ascension and Gough Islands: Science, v. 145, p. 1181.

Goldsmith, J. R., Graf, D. L., Chodos, A. A., Joensuu, O. I., and McVicker, L. D., 1958. Relation between lattice constants and composition of the Ca-Mg carbonates: Am. Mineral. v. 43, p. 84

Green, D. H., 1971. Composition of basaltic magmas as indicators of conditions of origin: application to oceanic volcanism: Roy. Soc. London Phil. Trans. A, v. 268, p. 707.

Hamilton, E. L., 1956. Sunken islands of the Mid-Pacific Mountains: Geol. Soc. Am. Mem. v. 64, p. 97.

Hart, S. R., 1971. K, Rb, Cs, Sr and Ba contents and $\mathrm{Sr}$ isotope ratios of ocean floor basalts: Roy. Soc. London Phil. Trans., A, v. 268, p. 573.

Hart, S. R. and Nalwalk, A. J., 1970. K, Rb, Cs and $\mathrm{Sr}$ relationships in submarine basalts from the Puerto Rico trench: Geochim. Cosmochim. Acta, v. 34, p. 145.

Hedge, C. E. and Peterman, Z. E., 1970. The strontium isotopic composition of basalts from the Gordo and Juan de Fuca Rises, northeastern Pacific Ocean: Contr. Min. Petrol., v. 27, p. 114.

Kay, R. Hubbard, N. J., and Gast, P. W., 1970. Chemical characteristics and origin of oceanic ridge volcanic rocks: J. Geophys. Res., v. 75, p. 1585.

Macdougall, D., 1971. Deep sea drilling: age and composition of an Atlantic basaltic intrusion: Science, $v$. 171, p. 1244.

McBirney, A. R. and Gass, I. G., 1967. Relations of Oceanic volcanic rocks to mud-ocean rises and heat flow: Earth Plan. Sci. Lett., v. 2, p. 265-276.

Matthews, D. H., 1971. Altered basalts from Swallow Bank, an abyssal hill in the NE Atlantic, and from a nearby seamount: Roy. Soc. London Phil. Trans., A, v. 268, p. 551

Miyashiro, A. and Shido, F., 1970. Progressive metamorphism in zeolite assemblages: Lithos, v. 3, p. 251.

Miyashiro, A., Shido, F., and Ewing, M., 1971. Metamorphism in the Mid-Atlantic Ridge near $24^{\circ}$ and $30^{\circ}$ N: Roy. Soc. London Phil. Trans., A, v. 268, p. 589.

Moore, C. B., Gibson, E. K., Larimer, J. W., Lewis, C. F., and Nichiporuk, W., 1970. Total carbon and nitrogen abundances in Apollo 11 lunar samples and selected achondrites and basalts: Geochim. Cosmochim. Acta, v. 34, Supple. 1, Apollo 11 Lunar Sci. Conf. Proc., v. 2, p. 1375.

Moore, J. G., 1965. Petrology of deep-sea basalt near Hawaii: Am. J. Sci. v. 263, p. 40.

Norrish, K. and Chappell, B. W., 1967. X-ray fluorescence spectrography. In Physical Methods in Determinative Mineralogy, J. Zussman (Ed.): London (Academic Press), p. 161.

Norrish, K. and Hutton, J. T., 1969. An accurate x-ray spectrographic method for the analysis of a wide range 
of geological samples: Geochim. Cosmochim. Acta, v. 33, p. 431.

Oversby, V. M. and Gast, P. W., 1970. Isotopic composition of lead from oceanic islands: J. Geophys. Res., v. 75, p. 2097.

Peterman, Z. E. and Hedge, C. E., 1971. Related strontium isotopic and chemical variations in oceanic basalts: Geol. Soc. Am. Bull., v. 82, p. 493.

Powell, J. L., Faure, G., and Hurley, P. M., 1965. Strontium 87 abundance in a suite of Hawaiian volcanic rocks of varying silica content: J. Geophys. Res., v. 70, p. 1509.

Shapiro, L. and Brannock, W. W., 1962. Rapid analysis of silicate, carbonate and phosphate rocks: U.S. Geol. Surv. Bull. 1144-A, 56 p.

Smith, J. R. and Yoder, H. S., Jr., 1956. Variations in x-ray powder diffraction patterns of plagioclase feldspars: Am. Mineral., v. 41, p. 632.

Smith, J. V. and Gay, P., 1958. The powder patterns and lattice parameters of plagioclase feldspars: II. Min. Mag., v. 31, p. 744 .
Tatsumoto, M., 1966a. Isotopic composition of lead in volcanic rocks from Hawaii, Iwo Jima, and Japan: J. Geophys. Res., v. 71, p. 1721. $1966 \mathrm{~b}$. Genetric relations of oceanic basalts as indicated by lead isotopes: Science, v. 153, p. 1094.

1969. Lead isotopes in volcanic rocks and possible ocean-floor thrusting beneath island arcs: Earth Plan. Sci. Lett., v. 6, p. 369.

Taylor, H. P., Jr., Frechen, J., and Degens, E. T., 1967. Oxygen and carbon isotope studies of carbonatites from the Laacher See district, West Germany and the Alno district, Sweden: Geochim. Cosmochim. Acta, v. 31, p. 407.

Tilley, C. E., 1950. Some aspects of magmatic evolution: Geol. Soc. London Quart. J., v. 106, p. 37.

Yoder, H. S., Jr., and Sahama, T. G., 1957. Olivine x-ray determinative curve: Am. Mineral., v. 42, p. 475.

Zen. E., 1961. The zeolite facies: an interpretation: Am. J. Sci., v. 259, p. 401. 



\section{PLATE 1}

Figure $1 \quad 164-28-1,87 \mathrm{~cm}$. Core of euhedral microphenocryst of plagioclase replaced by K-feldspar and fine-grained montmorillonite. Crossed polarizers.

Figure $2 \quad 164-28-2 \mathrm{~m} 116 \mathrm{~cm}$ (b). Selective replacement of zone near surface of plagioclase microphenocryst by colorless or very light green montmorillonite and minor K-feldspar. Montmorillonite is probably Fe-poor, Al-rich. Crossed polarizers.

Figure $3 \quad 164-28-2,116 \mathrm{~cm}$ (b). Calcite pseudomorph after skeletal olivine microphenocryst. Plain light.

Figure $4 \quad 164-28-6,137 \mathrm{~cm}$. Green and brown montmorillonite pseudomorph after euhedral olivine microphenocryst. Montmorillonite probably contains significant $\mathrm{Fe}$, $\mathrm{Mg}$, and Al. Plain light.

Figure 5

165A-24-1, 117-121 cm. Calcite (white) along contact between fine-grained xenolith and flowbanded selvage of microphyric, slightly vesicular, brown, altered, originally glassy host rock (dark). Plain light.

Figure 6

165 A-24-1, 117-121 cm. Xenolith in altered glassy flow (same as in Figure 5), showing typical lithology (on left) in contact with relatively volatile-rich pegmatoid patch (on right). Main lithology is relatively rich in pyroxene and opaque minerals, pegmatoid patch in brown kaersutitic(?) amphibole and calcite. Other related patches are finer grained and richer in amphibole than the one shown. Plain light.

Figure $7 \quad 165$ A-24-1, 117-121 cm. Brown kaersutitic(?) amphibole prisms and clusters of euhedral opaque grains in ovoid calcite patch. Texture suggests crystallization of amphibole and opaque mineral from immiscible carbonatite magma (compare Figure 8). Plain light.

Figure $8 \quad 165 \mathrm{~A}-24-1,117-121 \mathrm{~cm}$. Brown kaersutitic(?) amphibole prisms and clusters of euhedral opaque grains in ovoid calcite patch. Sharp line bounding ends of amphibole prisms suggests relict inner wall of vug later filled by calcite (magmatic or diagenetic?), in which case the evidence for precipitation of amphibole from an immiscible carbonatitic melt (as in Figure 7 above) is questionable. Plain light. 
PLATE
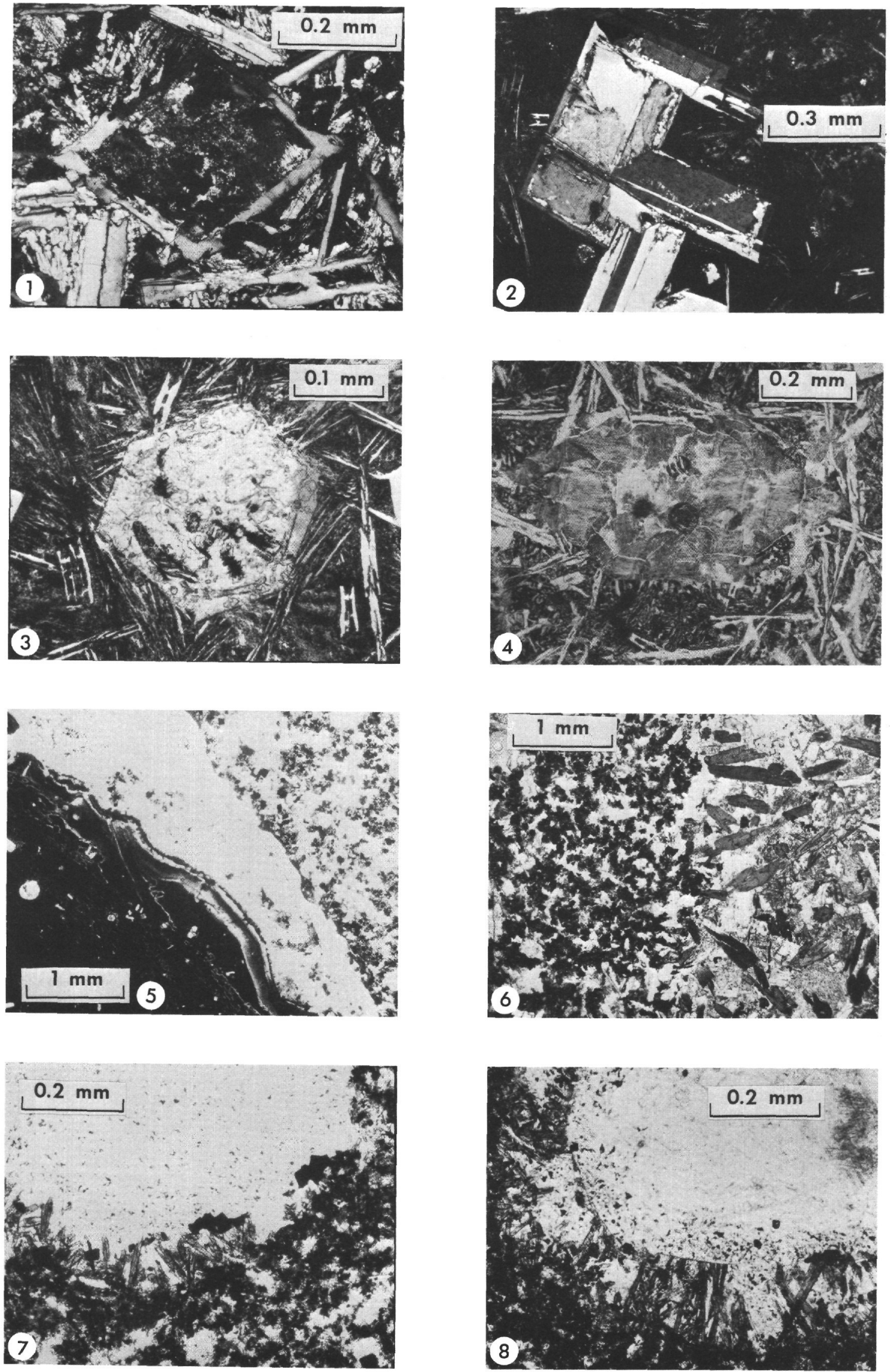
PLATE 2

Figure 1

Figure 2

Figure 3

Figure 4

Figure 5

Figure 6

Figure 7

Figure 8
165A-27-CC. Plagioclase remnants in secondary chabazite and gmelinite. Outer edges of plagioclase are preferentially preserved, and more so in this area than elsewhere in the rock. Dark and light gray in zeolites reflect $\mathrm{Fe}$ oxide pigmentation as well as extinction differences. Crossed polarizers.

166-29-2, 16-25 cm. Chilled selvage of pillow showing gradation from glass to isolated spherulites to a continuous zone of coalesced spherulites. Microphenocrysts and glomerophenocrysts are composed of pyroxene (strongly sector zoned), plagioclase, and montmorillonite pseudomorphs after olivine. Olivine evidently alters faster than glass. The montmorillonite is a mixture of large red brown flakes and fine-grained, fibrous, yellow to light green masses; in upper right (immediately to left of hole in section) these types are zonally arranged. Plain light.

167-94-2, 137-140 cm. Ovoid mass of light olive montmorillonite rosettes with dark brown rim. The mass may be an amygdule or an altered patch of chlorophaeite. Calcite vein in lower right. Partial replacement of plagioclase by olive brown montmorillonite in upper right and upper left. Crossed polarizers.

167-94-3, 78-84 cm. Optically parallel pyroxene remnants in brown to olive brown montmorillonite. Crossed polarizers.

167-94-3, 78 to $84 \mathrm{~cm}$. Same as Figure above but rotated so that pyroxene remnants are at extinction. Crossed polarizers.

167-92-2, 40-43 cm. Core of plagioclase phenocryst replaced by K-feldspar and minor green montmorillonite. Note sodic rims around groundmass inclusions which are due either to hollow growth habit or to stage of reaction with or resportion by magma. Epoxy on lower right. Crossed polarizers.

167-95-2, 40-43 cm. Irregular mass of light olive montmorillonite rosettes with thin, medium brown, transparent rim of very fine-grained montmorillonite. Dark areas, which are rich in very fine-grained opaque minerals, contain ovoids like the rim of the larger mass. The larger ovoids contain cores of light brown to light olive montmorillonite like that in the large mass, and similarly arranged in rosettes or cross-fiber fringes. The detailed shape of the large mass is unlike that of a vesicle and suggests that the mass is not an amygdule, bit either an altered patch of chlorophaeite or a diagenetic replacement of the host rock. The concentration of opaque minerals is either primary or a metasomatic "front"; a primary origin seems more likely and would support an origin as an altered mass of chlorophaeite. Plain light.

167-95-2, 40-43 cm. Same as Figure 7 above, crossed polarizers. 
PLATE 2
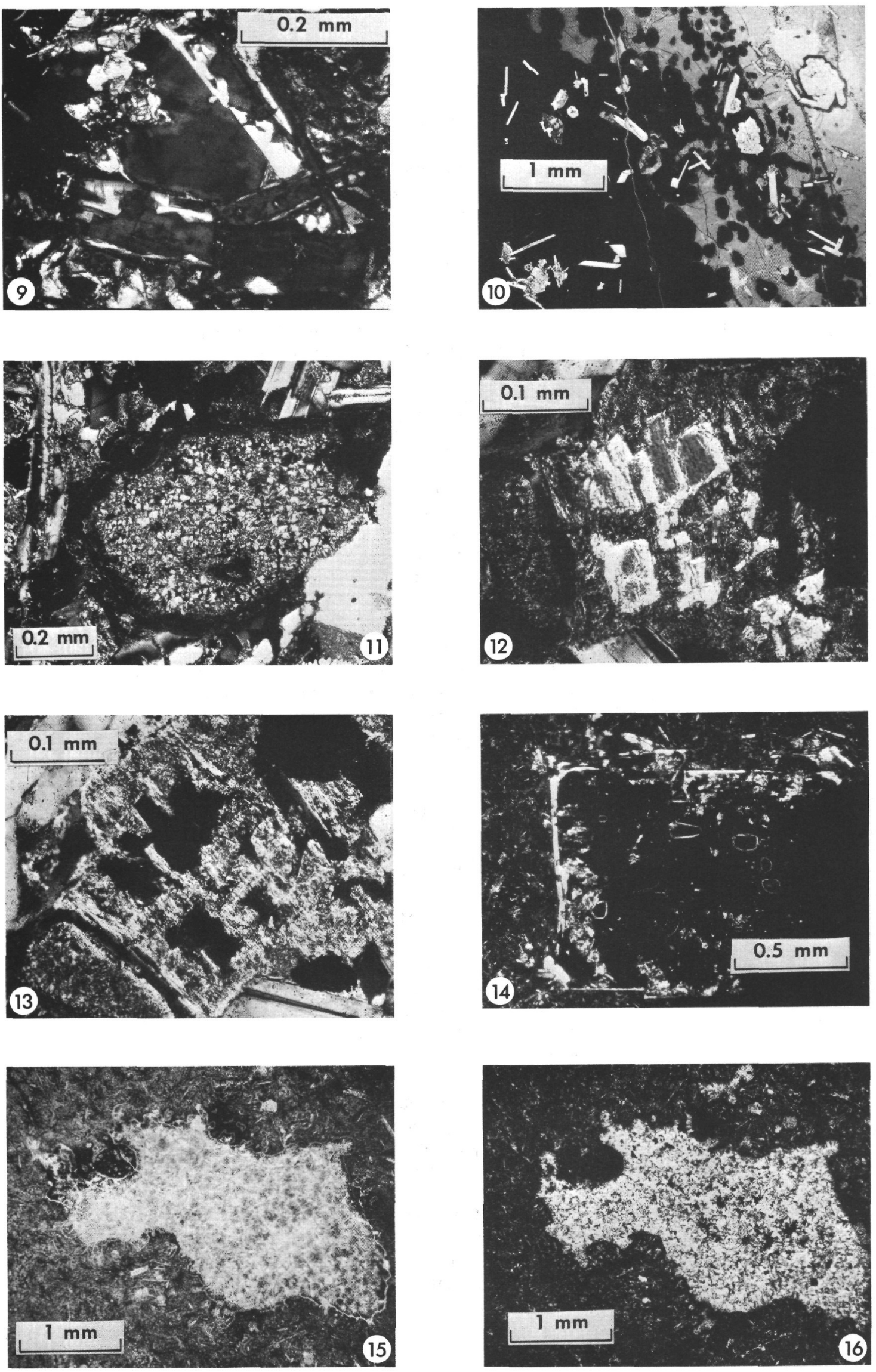


\section{PLATE 3}

Figure 1

Figure 2

Figure 3

Figure 4

Figure 5

Figure 6

Figure 7

Figure 8
$169-5-1,21$ to $24 \mathrm{~cm}$. Cores of plagioclase grains replaced to varying extents by $\mathrm{K}$-feldspar near the upper contact of sill which intruded upper Cenomanian or lower Turonian sediments. A concentration of such K-feldspar gives a K-Ar age of $58 \pm 2$ m.y. Crossed polarizers.

$169-6-2, \quad 19$ to $20 \mathrm{~cm}$. Radial phillipsite in phillipsite-rich area. Crossed polarizers.

169-6-2, 19-20 cm. Cruciform-twinned phillipsite in same phillipsite-rich area as Figure 2 above. Crossed polarizers.

169-6-2, 19-20 cm. Euhedral, inclusion-rich apatite in same phillipsite-rich area as Figures 2 and 3 above. This is the only such crystal seen. Phillipsite in upper right and upper left; green and brown interstitial chlorite in lower left and top center; plagioclase lath in lower right. Plain light.

169-6-2, 19-20 cm. Host diabase near the phillipsiterich area of Figures 2 and 3, and 4 above. Abundant veins in plagioclase are probably chabazite or phillipsite; the veins are somewhat more common here than in other, less zeolitic parts of the sill. Plain light.

169-6-3, 33-38 cm. Olivine replaced by brown montmorillonite along cleavages. From freshest part of sill as judged by relict olivine. Dark patch on lower right edge of olivine is green chlorite. Plain light.

169-6-3, 33-38 cm. Mantle of dark brown to greenish brown amphibole which grades, through a medium green zone, to very light brown pyroxene. Amphibole is probably a primary late-magmatic overgrowth, but it may be a replacement of pyroxene. Opaque inclusions in both amphibole and pyroxene. Plain light.

169-6-3, 33 to $38 \mathrm{~cm}$. Dark brown amphibole prism which gives way abruptly to colorless or very light green prismatic to acicular amphibole. They are embedded in pleochroic green to colorless intersertal chlorite. The brown amphibole is probably late magmatic; the colorless amphibole is probably deuteric, but appears to be a direct precipitate from late fluids rather than a replacement of an earlier mineral. Plain light. 
PLATE 3
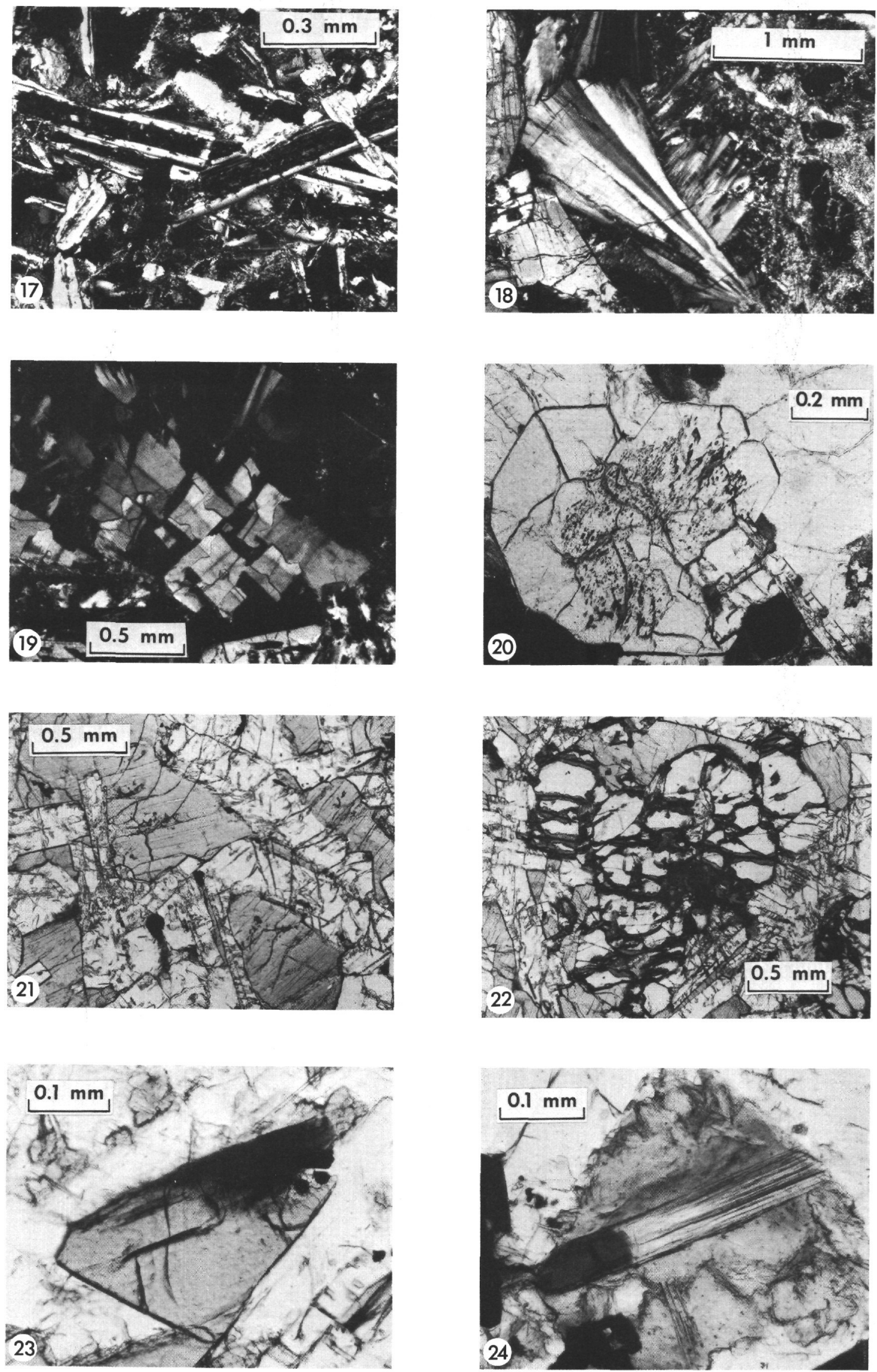


\section{PLATE 4}

Figure $1 \quad 169-6-3,33$ to $38 \mathrm{~cm}$. Euhedral, brown, late-magmatic amphibole (cross-section of prism like that in Plate 3, Figure 8 and ovoid pyroxene embedded in pleochroic green to colorless intersertal chlorite. Plain light.

Figure $2 \quad 169-6-5,141-144 \mathrm{~cm}$. Glomerophenocryst about 3 $\mathrm{cm}$ above base of sill. Cores of plagioclase altered to $\mathrm{K}$-feldspar and calcite; pyroxene and olivine wholly altered to calcite. Plain light.

Figure 3 169-6-5, 141-144 cm. Same as Figure 2 above, crossed polarizers.

Figure $4 \quad 169-6-5,141-144 \mathrm{~cm}$. Calcite pseudomorph after euhedral olivine with skeletal ends. Plain light.

Figure 5 169-11-CC. Glomerophenocryst in basement flow below sill, composed of plagioclase, pyroxene and green montmorillonite pseudomorphs after olivine. Plain light.

Figure 6

169-11-CC. Same as Figure 5 above, crossed polarizers.

Figure 7 170-10-CC. Mugearite porphyry. Dark areas in matrix are feathery, subradial varioles. Not clearly visible in matrix are abundant opaque dendrites which contrast strongly in habit with the visible clusters of equant, euhedral opaque grains. Plain light.

Figure $8 \quad 170-16-1,17-19$. Fine-grained upper part of sill showing pyroxene microphenocryst, slightly altered to calcite, and celadonite pseudomorph after olivine microphenocryst, in a matrix composed of plagioclase, opaque grains, and a mass of celadonite which wholly replaces the groundmass pyroxene and the intersertal residuum. Plain light. 


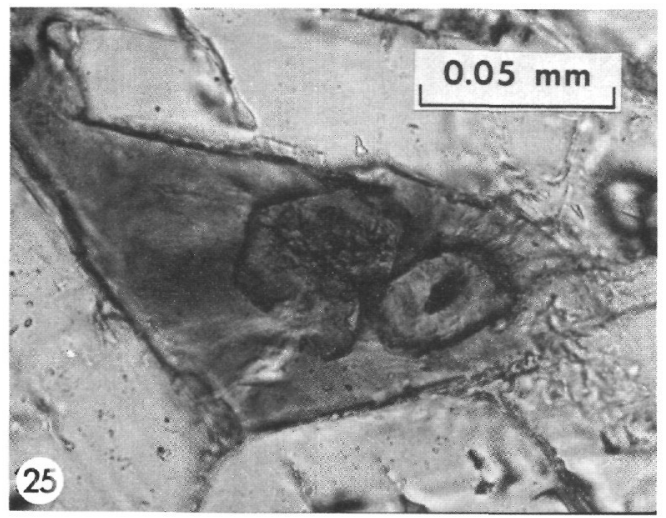

PLATE 4
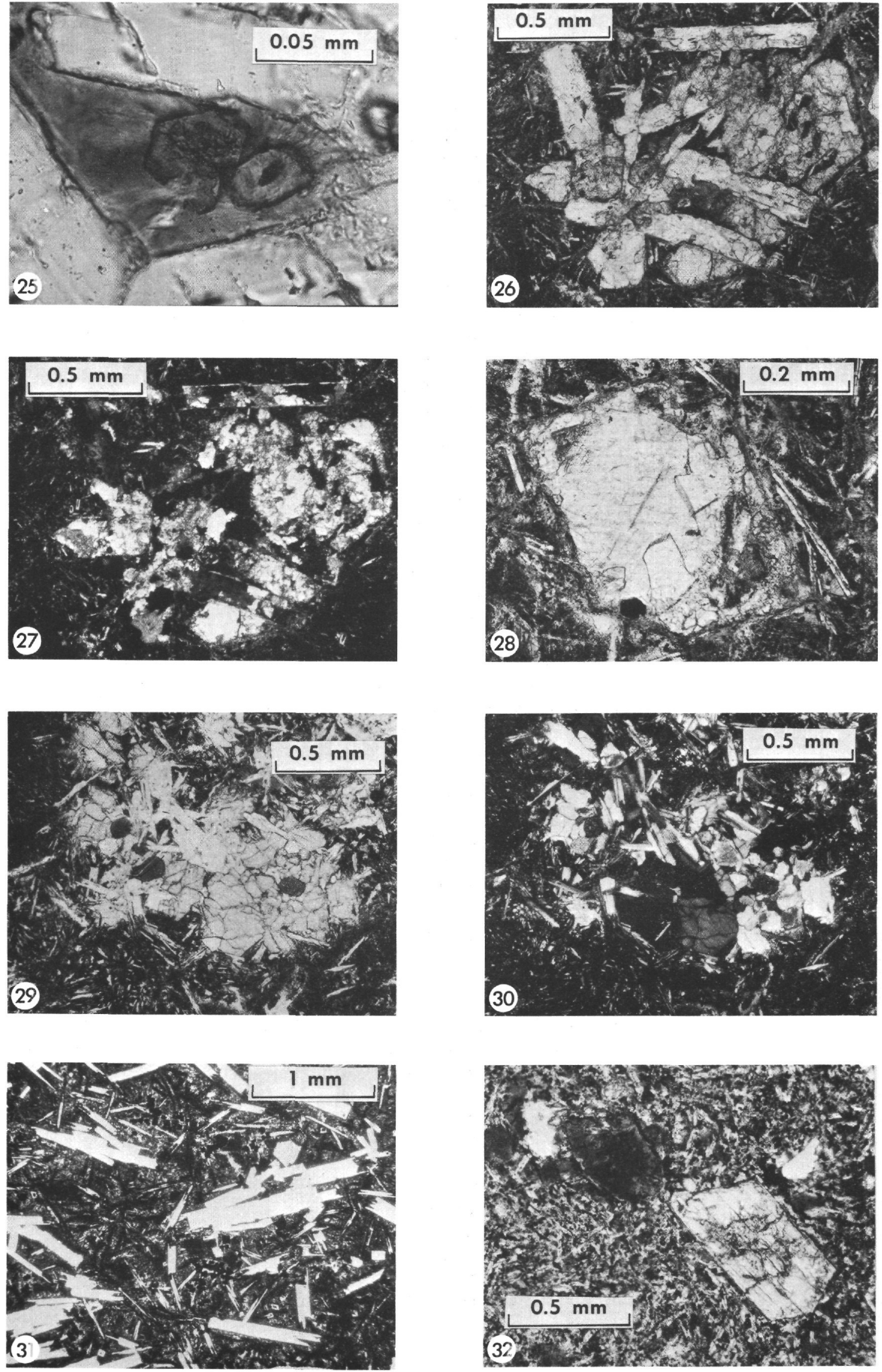


\section{PLATE 5}

Figure $1 \quad 170-16-1,24-37 \mathrm{~cm}$. Diabase, in sill just below the area shown in Plate 4, Figure 8 . Center of upper pyroxene microphenocryst is replaced by calcite. Most groundmass pyroxene and all intersertal residuum are replaced by dark mixture of montmorillonite and calcite. Rare celadonite (not seen in Figure) is restricted to tiny patches and lenticular seams. Plain light.

Figure $2 \quad 170-16-2,61-70 \mathrm{~cm}$. Colorless to very light yellow green, acicular, deuteric amphibole in diabase, still deeper in sill than areas shown in Plate 4, Figure 8 and Figure 1 above. Amphibole in this case grew at end of, and possibly replaced, pyroxene, of which a remnant, embedded in montmorillonite, is seen in right center. Most amphibole in the sill occurs as isolated, fibrous bundles embedded in intersertal, olive-colored montmorillonite accompanied by little or no calcite. Celadonite patches are rare. Plain light.

Figure $3 \quad 170-16-2,144-147 \mathrm{~cm}$. Diabase still deeper in sill than areas shown in Plate 4, Figure 8 and Figures 1 and 2 ahove. Pyroxene survives to a moderate extent in this local area, but is nonetheless largely altered to brown montmorillonite with very little or no calcite. Plain light.

Figure 4 171-26-CC. Brown montmorillonite in three modes of occurrence. In upper right are pseudomorphs of brown montmorillonite and minor calcite after subhedral olivine with opaque inclusions and relict mesh structure. In lower right are brown montmorillonite ovoids with radial and concentric structure, and on the left are montmorillonite ovoids with brown cores and olive green rims, both with radial structure. The ovoids appear to be a special mode of alteration of the groundmass; they seem to be too abundant to be amygdules or altered chlorophaeite. Plain light.

Figure $5 \quad 171-27-2,75-86 \mathrm{~cm}$. Ovoid cluster of rosettes and cross-fiber bands of brown montmorillonite, surrounded by opaque rim, in highly altered basalt. The rosettes probably account for the micronodular appearance of such masses under a binocular microscope. The ovoid mass may be an amygdule or an altered mass of chlorophaeite. Plain light.

Figure $6 \quad 171-27-2,75-86 \mathrm{~cm}$. Same as Figure 5 above, crossed polarizers.

Figure $7 \quad 171-27-2,75-86 \mathrm{~cm}$. Brown montmorillonite pseudomorph after subhedral olivine immediately to right of center. Pseudomorph has relict mesh structure and opaque spinel inclusion. Identical-looking montmorillonite nearby occupies ovoids with radial and concentric structure. The center of the largest ovoid (immediately to left of altered olivine) is semiopaque due to dark dusty inclusions. The ovoids appear to be altered groundmass, but the largest one may be an amygdule or an altered mass of chlorophaeite. Plain light.

Figure 8 171-27-3, 80-92 cm. Brown montmorillonite in two modes of occurrence. In the center of figure it forms a pseudomorph after anhedral or subhedral olivine with relict mesh structure and euhedral, opaque spinel inclusions. In the lower part of figure it forms ovoids with concentric and radial structure. The ovoids may be altered groundmass, amygdules or altered chlorophaeite. Plain light. 
PLATE 5
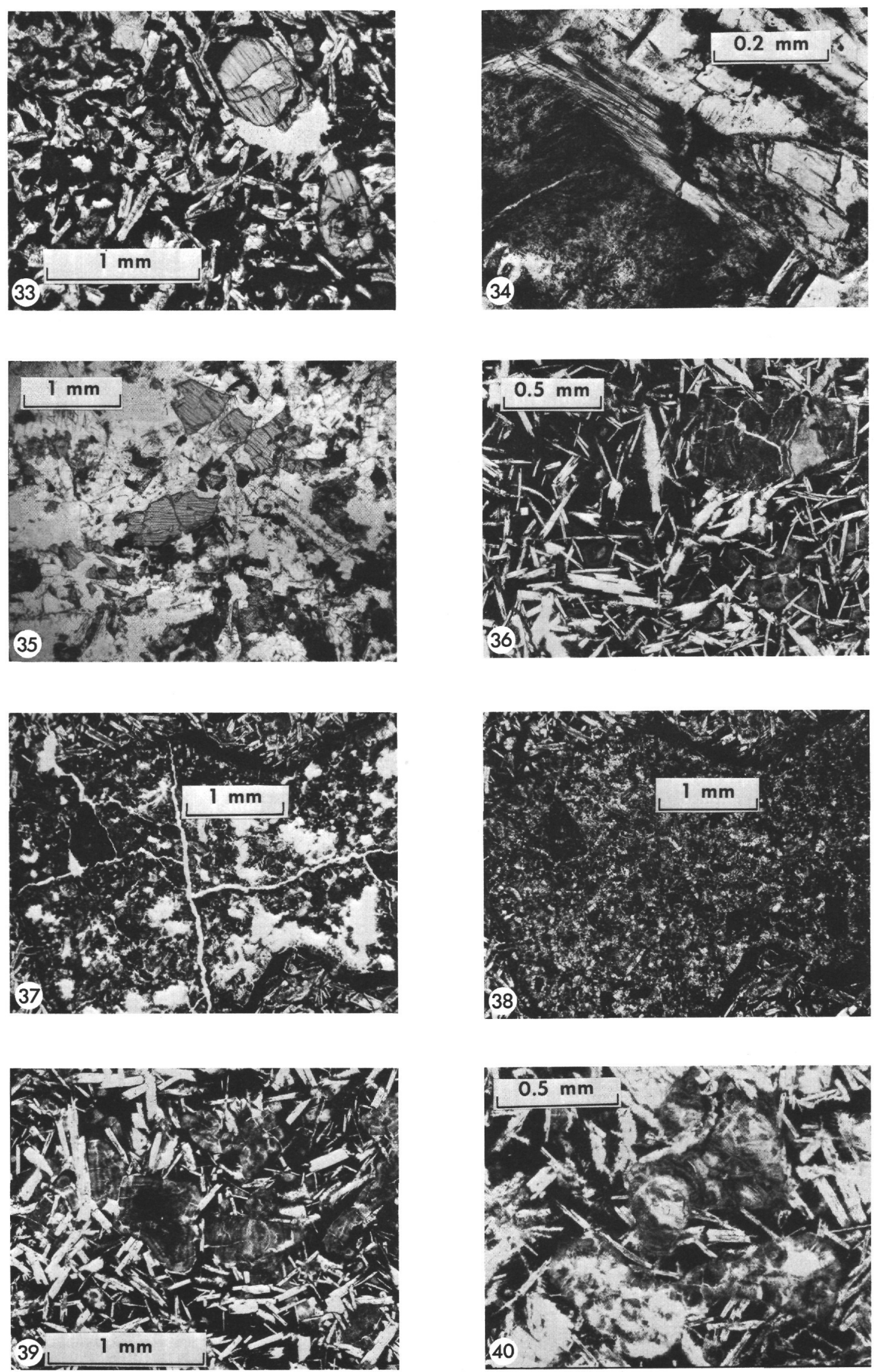
PLATE 6
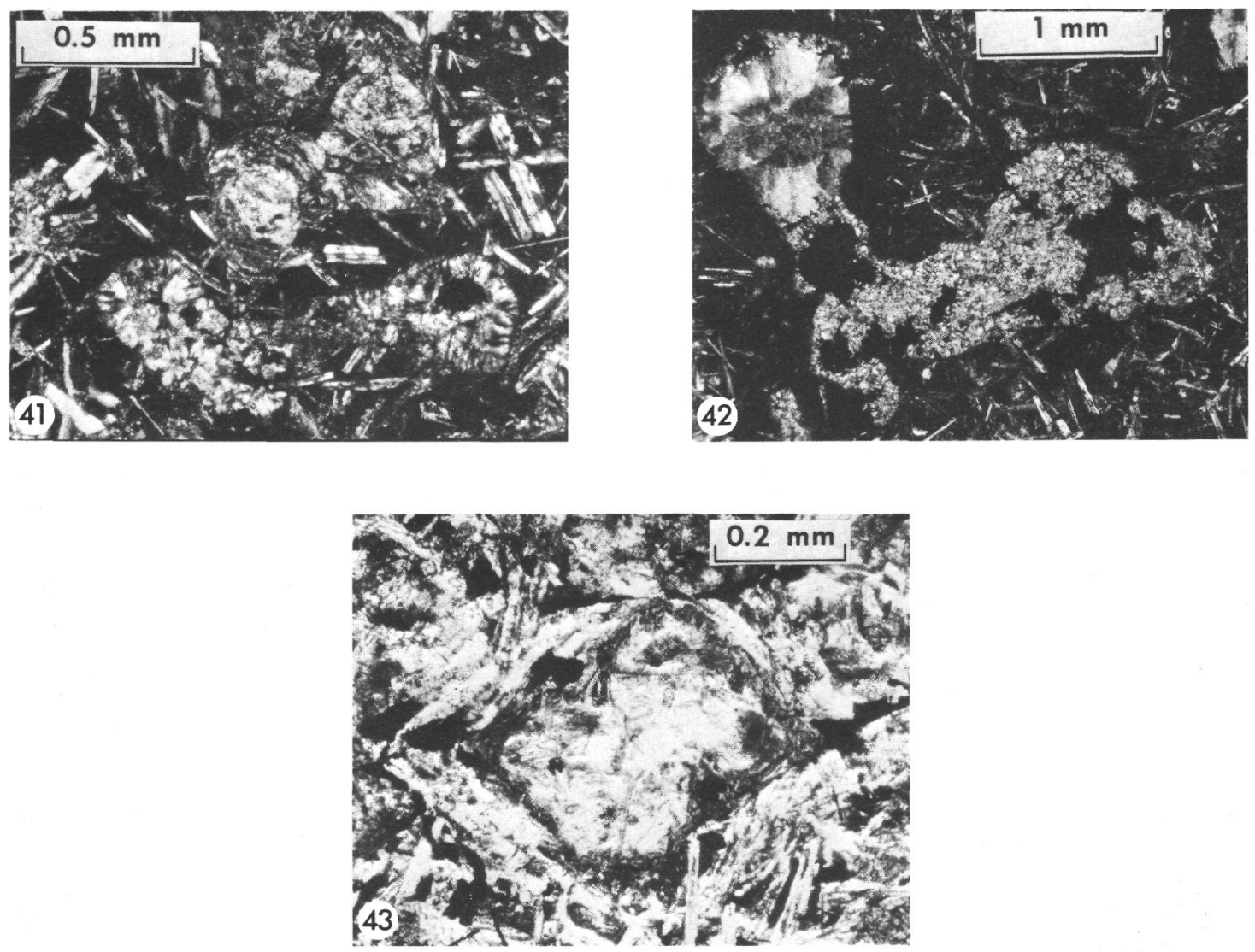

Figure 1

171-27-3, 80-92 cm. Same as Plate 5, Figure 8, crossed polarizers.

Figure $2171-27-3,80-92 \mathrm{~cm}$. Irregular mass, with thin brown montmorillonite rim, filled with light olive rosettes of montmorillonite except at one end which is occupied by calcite crystals which radiate from a dusty core of calcite. The rosettes are probably micronodular megascopically or under a binocular microscope. Crossed polarizers.

Figure 3 171-33-CC. Light brown montmorillonite pseudomorph after euhedral olivine microphenocryst with iddingsite rim. Iddingsite occurs as large, moderately pleochroic, red brown to light orange brown flakes which replace the rims and cracks of olivine microphenocrysts and all groundmass olivine. This distribution indicates late magmatic oxidation. Plain light. 
APPENDIX A

X-Ray Mineralogy of Volcanic Rocks, DSDP Leg 17

\begin{tabular}{|c|c|c|c|}
\hline Specimen & Rock Type & Comments & Mineralogy (X-Ray) \\
\hline \multicolumn{4}{|l|}{ Site 164} \\
\hline \multirow[t]{2}{*}{$27-1,102 \mathrm{~cm}$} & Basalt & $\begin{array}{l}\text { Light gray variolitic; avoid brown altered (more } \\
\text { chilled?) edge in X-rayed sample }\end{array}$ & PLAG., CPX.; Minor Calc., K-fld., Mont. \\
\hline & $\begin{array}{l}\text { Celad. (?) and Calc. } \\
\text { veins and vesicle } \\
\text { fillings }\end{array}$ & $1 \mathrm{MD}$ mica & CELAD., CALC.; trace mont. \\
\hline $27-2,102-106 \mathrm{~cm}$ & Basalt & Total rock; no chl. detected & PLAG., CPX; Minor K-fld, Mont. \\
\hline $27-1,123 \mathrm{~cm}$ & Amygdules & $\begin{array}{l}\text { Green patches and irregular "amygdules" in altered } \\
\text { basalt; avoid veins composed of calc. and green } \\
\text { mineral }\end{array}$ & $\begin{array}{l}\text { MONT., CELAD.; Plag. and CPX. } \\
\text { (contamination) trace calc. }\end{array}$ \\
\hline $27-1,123.5-124.5 \mathrm{~cm}$ & $\begin{array}{l}\text { Green lenses and } \\
\text { patches in calc. } \\
\text { vein }\end{array}$ & $\begin{array}{l}\text { Dark green, resinous, soft, crunchy, conchoidal; host } \\
\text { contamination; no mont.; 1Md mica }\end{array}$ & $\begin{array}{l}\text { CELAD., CALC.; trace plag., cpx. } \\
\text { Contamination }\end{array}$ \\
\hline $28-1,87 \mathrm{~cm}$ & Basalt & Total rock; no ch1.; K-fld. confirmed in thin section & PLAG., CPX.; Minor Mont.; trace K-fld. \\
\hline $28-2,116 \mathrm{~cm}(\mathrm{~b})$ & Basalt & Total rock; no chl. & PLAG., CPX., Minor Mont.; trace K-fld. \\
\hline $28-2,116 \mathrm{~cm}(\mathrm{a})$ & Brown vein & $\begin{array}{l}\text { On surface of green and brownish gray altered glass } \\
\text { with vertical lamination (side of pillow?) }\end{array}$ & PHIL.; Minor Mont.; trace calc. \\
\hline $28-5,85 \mathrm{~cm}(\mathrm{~b})$ & Basalt & Total rock; no chl. & PLAG.; CPX.; Minor Mont.; trace K-fld. \\
\hline $28-5,85 \mathrm{~cm}(\mathrm{a})$ & $\begin{array}{l}\text { Green walls and } \\
\text { minor calc. from } \\
\text { center of zoned } \\
\text { vein }\end{array}$ & Emphasize walls in $\mathrm{X}$-rayed sample & CALC.; minor Mont.; trace celad. \\
\hline $28-6,137 \mathrm{~cm}$ & Basalt & $\begin{array}{l}\text { Total rock; trace K-fld. replacing plag. phenocrysts } \\
\text { in thin section, but much less than in other rocks } \\
\text { from Hole } 164\end{array}$ & PLAG., CPX.; minor Mont.; trace K-fld. \\
\hline $28-6,144 \mathrm{~cm}(\mathrm{~b})$ & Basalt & Total rock; no chl. & PLAG., CPX.; Minor Mont.; trace K-fld. \\
\hline \multicolumn{4}{|l|}{ Hole 165A } \\
\hline $24-1,75-78 \mathrm{~cm}$ & Basalt & Total rock & $\begin{array}{l}\text { PLAG., CPX., ILM.; Minor K-fld., Mica, } \\
\text { Amph., Mont.; trace calc. }\end{array}$ \\
\hline \multirow[t]{4}{*}{$24-1,117-121 \mathrm{~cm}$} & Basalt & $\begin{array}{l}\text { Gray host basalt sampled away from selvage adjacent } \\
\text { to inclusion }\end{array}$ & $\begin{array}{l}\text { MONT., PLAG., CPX., ILM.; Minor K-fld., } \\
\text { Amph., Mica, Apat.; trace or minor anat. }\end{array}$ \\
\hline & Basalt & Gray host as above & $\begin{array}{l}\text { MONT., PLAG., CPX., ILM.; Minor K-fld., } \\
\text { Amph., Mica, Apat.; trace or minor anat. }\end{array}$ \\
\hline & $\begin{array}{l}\text { Basalt; selvage of } \\
\text { host against } \\
\text { inclusion }\end{array}$ & $\begin{array}{l}\text { Dark gray; grades along contact to grayish brown } \\
\text { selvage (see below). The titanomagnetite is Us } 15 \\
\text { if it lies on the Us-Mt join. The mont. is a mixture } \\
\text { of Na-saturated and non-Na-saturated types. In the } \\
\text { grayish brown part of the selvage (see below), the } \\
\text { mont. is non-Na-saturated, with only a faint sugges- } \\
\text { tion of Na-saturated mont. }\end{array}$ & $\begin{array}{l}\text { PLAG., AMPH., CPX., MONT., ILM., } \\
\left.\text { TITANOMAGN. ( } \mathrm{a}_{\mathrm{O}}=8.407 \AA\right) \text {; trace } \\
\text { mica, anat., calc., K-fld. }\end{array}$ \\
\hline & $\begin{array}{l}\text { Basalt; selvage of } \\
\text { host against } \\
\text { inclusion }\end{array}$ & $\begin{array}{l}\text { Medium grayish brown, streaky, soft, very minor } \\
\text { microphenocrysts; sample highly cracked on drying } \\
\text { in air. Rock is } \mathrm{TiO}_{2} \text {-rich to judge from abundant } \\
\text { anatase }\end{array}$ & $\begin{array}{l}\text { PLAG., CPX., MICA, ANAT.; Minor Mont., } \\
\text { Amph.; trace calc., ilm., goet. }\end{array}$ \\
\hline
\end{tabular}

Note: X-Ray mineralogy results are based on X-ray powder patterns of whole rocks; special parts of rocks selected megascopically or under a binocular microscope on the basis of structure, texture or color; and various fractions of crushed rocks separated by means of heavy liquids and a hand magnet. The specimens are presented in sequence by the number of the drill site and from shallow to deep at any given site. Relative abundances of minerals were estimated by relative peak heights, taking into account the heights of the peaks in similar mounts of the pure minerals. Three arbitrary abundance classes were set up as follows: abundant (names in capital letters); minor (first letters capitalized); and trace (no capital letters except for chemical element symbols, as in K-fld). No strict quantitative significance should be assigned to these classes. For any given specimen the abundance groups are given in order of decreasing abundance, but within any given group no relative abundance is implied by the order in which the names are cited. 


\begin{tabular}{|c|c|c|c|}
\hline Specimen & Rock Type & Comments & Mineralogy (X-Ray) \\
\hline \multicolumn{4}{|c|}{ Hole 165A - Continued } \\
\hline & $\begin{array}{l}\text { Basalt; selvage of } \\
\text { host against } \\
\text { inclusion }\end{array}$ & $\begin{array}{l}\text { Same. Medium grayish brown, but from a different } \\
\text { spot; the mineralogy of the brownish selvage is } \\
\text { apparen tly variable mont. is more abundant in this } \\
\text { sample compared to that above, whereas plag. and } \\
\text { cpx. are less abundant. The mica is apparently a } \\
\text { secondary alteration product of glass }\end{array}$ & $\begin{array}{l}\text { MICA, ANAT., MONT., PLAG., CPX.; trace } \\
\text { amph., calc., goet. }\end{array}$ \\
\hline & Basalt inclusion & Gray, much calc. & $\begin{array}{l}\text { MONT., CALC., CPX.; Minor Plag.; Minor } \\
\text { or trace amph.; trace K-fld., mt, mica, apat. }\end{array}$ \\
\hline $24-1,117-121 \mathrm{~cm}$ & Basalt inclusion & $\begin{array}{l}\text { Gray, very little calc.; fragment of the piece used } \\
\text { for chemical analy sis; modal composition is evidently } \\
\text { highly variable. To judge from the unit cell edge, the } \\
\text { MT is nearly pure, with possibly a slight amount of } \\
\text { maghem. in solid solution }\end{array}$ & $\begin{array}{l}\text { MONT., CPX., PLAG., MICA, MT }\left(\mathrm{a}_{\mathrm{o}}=\right. \\
8.392 \text { A); Minor Amph., K-fld.; trace calc. }\end{array}$ \\
\hline \multirow{6}{*}{$\begin{array}{l}24-1,117-121 \mathrm{~cm} \\
\quad \text { (host) }\end{array}$} & \multicolumn{3}{|c|}{ Calc. in various modes of occurrence, corresponding to some of the types analyzed isotopically by $\mathrm{H}$. Craig: } \\
\hline & $\begin{array}{l}\text { Large }\left(1^{+} \mathrm{cm}\right) \\
\text { ovoid }\end{array}$ & & 2.0 mole $\% \mathrm{MgCO}_{3}$ \\
\hline & $\begin{array}{l}\text { Small ovoids } \\
(<2 \mathrm{~mm})\end{array}$ & Sample mount is rough surfaced & $\begin{array}{l}\mathrm{d}_{(633)}: 2.5^{-} \text {mole } \% \mathrm{MgCO}_{3} \\
\mathrm{~d}_{(211)}: 0 \quad \text { mole } \% \mathrm{MgCO}_{3}\end{array}$ \\
\hline & $\begin{array}{l}\text { Small ovoids } \\
(<2 \mathrm{~mm})\end{array}$ & $\begin{array}{l}\text { Sample remounted on slide, surface smoothed; } \\
\text { precision and accuracy are strongly affected by peak } \\
\text { shape and resolution of } K \alpha_{1} \text { and } K \alpha_{2} \text { peaks, which } \\
\text { in turn, are strongly affected by the roughness of } \\
\text { the sample surface (and less so by the thickness of } \\
\text { the sample on the slide) }\end{array}$ & $\begin{array}{l}\mathrm{d}_{(633)}: 2.5^{-} \text {mole } \% \mathrm{MgCO}_{3} \\
\mathrm{~d}_{(211)}: 2.0^{-} \text {or } 1.5^{+} \text {mole } \% \mathrm{MgCO}_{3}\end{array}$ \\
\hline & Vein & Rough sample surface & $\begin{array}{l}\mathrm{d}_{(633)}: 2.0^{-} \text {or } 1.5^{+} \text {mole } \% \mathrm{MgCO}_{3} \\
\mathrm{~d}_{(211)}: 1.0^{+} \text {mole } \% \mathrm{MgCO}_{3}\end{array}$ \\
\hline & Vein & $\begin{array}{l}\text { Same sample mount, but surface smoothed; precision } \\
\text { and accuracy improved due to better peak shape and } \\
\text { resolution of } K \alpha_{1} \text { and } K \alpha_{2} \text { peaks }\end{array}$ & $\begin{aligned} \mathrm{d}_{(633)} \text { range of composition with median } \\
\text { at } 1.5^{-} \text {mole } \% \mathrm{MgCO}_{3} \text { and mode } \\
\text { at } 1.0^{+} \text {to } 1.5^{-} \text {mole } \% \mathrm{MgCO}_{3} \\
\mathrm{~d}_{(211)}: 1.5 \text { mole } \% \mathrm{MgCO}_{3}\end{aligned}$ \\
\hline \multirow[t]{9}{*}{$26-2,80-84 \mathrm{~cm}$} & Basalt & Total rock; relatively poor in plag. & $\begin{array}{l}\text { PLAG., CPX., AMPH.; Minor Mica, K-fld., } \\
\text { Chl., Ilm.; trace apat., mont. }\end{array}$ \\
\hline & \multicolumn{3}{|c|}{ Density and magnetic fractions of the crushed basalt: } \\
\hline & & Apparently Ca-rich and perhaps Fe-rich & $\begin{array}{l}\text { CPX. } \\
\text { AMPH. }\end{array}$ \\
\hline & & $\begin{array}{l}\text { Andesine? If so, the rock is a hawaiite, in accord } \\
\text { with the chemical data (Table 1). Larger peak } \\
\text { separations are found in denser plagioclase fractions, } \\
\text { so it is compositionally variable. }\end{array}$ & $\begin{array}{l}\text { PLAG.; peak separations are uncertain } \\
\text { because of interferences, but appear to be: } \\
\begin{aligned} \Delta 2 \theta= & 1.67 \text { or } 1.79^{\circ} ; \max . \text { An content } \\
& =\mathrm{An} 28 \text { or An } 46\end{aligned} \\
\begin{aligned} \Gamma \quad & +0.31 \text { or }+0.54 ; \max . \text { An content } \\
& =\mathrm{An} 36 \text { or An } 58\end{aligned}\end{array}$ \\
\hline & & $\begin{array}{l}\text { Probably potassic andesine or oligoclase; if it were } \\
\text { an alkali feldspar it would be Or } 14\end{array}$ & $\left.\mathrm{~d}_{(\overline{2}} 01\right)=4.058 \AA$ \\
\hline & & $\begin{array}{l}\text { Probably rims on plag. and late interstitial feldspar; } \\
\text { if it is an alkali feldspar it is Or } 33\end{array}$ & $\mathrm{~d}_{(\overline{2} 01)}=4.099 \AA$ \\
\hline & & $\begin{array}{l}\text { Pure K-fld.; it is probably diagenetic K-fld. which } \\
\text { replaces plag. }\end{array}$ & $\begin{array}{l}\mathrm{d}(\overline{2} 01)=4.236 \AA \\
\text { Ilm. } \\
\text { Ch1. }\end{array}$ \\
\hline & & $\mathrm{Us}_{10}$ if it lies on Us-Mt join & $\begin{array}{l}\text { Titanomagn. }\left(\mathrm{a}_{\mathrm{O}}=8.399 \AA\right) \\
\text { Mica } \\
\text { apat. - trace } \\
\text { mont. - trace }\end{array}$ \\
\hline & & Light yellow sulfide & pyrite \\
\hline $26-2,80-84 \mathrm{~cm}$ & Exposed joint & Light blue green microbotryoidal clay with scat- & MONT., CHL., PYRITE. \\
\hline
\end{tabular}


APPENDIX A - Continued

\begin{tabular}{|c|c|c|c|}
\hline Specimen & Rock Type & Comments & Mineralogy (X-Ray) \\
\hline \multicolumn{4}{|c|}{ Hole 165A - Continued } \\
\hline $26-2,80-84 \mathrm{~cm}$ & Vein & Soft, white; calc., sulfide and blue green clay & $\begin{array}{l}\text { CALC., PYRITE, CHL., MONT., MIXED- } \\
\text { LAYER CHL.-MONT. }\end{array}$ \\
\hline $27-2,60-65 \mathrm{~cm}$ & Basalt & $\begin{array}{l}\text { Total rock, relatively poor in plag. "Natr." has some } \\
\text { characteristics of thom. in other X-ray patterns- } \\
\text { see below }\end{array}$ & $\begin{array}{l}\text { PLAG., CPX., AMPH.; Minor Mica, Ch1., } \\
\text { Ilm., K-fld., Chab., Gmel.; trace apat., } \\
\text { mont., "natr." }\end{array}$ \\
\hline \multirow[t]{2}{*}{$27-2,60-65 \mathrm{~cm}$} & Basalt & $\begin{array}{l}\text { Total rock, from same part of specimen as sample } \\
\text { from which density fractions were separated (see } \\
\text { below); rock apparently highly variable modally }\end{array}$ & $\begin{array}{l}\text { AMPH., PLAG., CPX., ILM.; Minor Mica; } \\
\text { trace chl., K-fld., analcite. }\end{array}$ \\
\hline & $\begin{array}{l}\text { Light green and } \\
\text { gray patches }\end{array}$ & $\begin{array}{l}\text { Probably altered phenocrysts(?) and patches rich in } \\
\text { zeolite and carbonate; "natr." hard to distinguish } \\
\text { from thom. }\end{array}$ & $\begin{array}{l}\text { CHAB., CPX., PLAG.; Minor Gmel., Ilm., } \\
\text { Amph; trace mont., calc., "natr.", analcite }\end{array}$ \\
\hline \multirow[t]{3}{*}{$27-2,60-65 \mathrm{~cm}$} & \multirow[t]{3}{*}{ Basalt } & \multicolumn{2}{|c|}{$\begin{array}{l}\text { Density and magnetic fractions: This sample may have been mixed up with } 165 \mathrm{~A}-27-\mathrm{CC} \\
\text { (see below). Non-magnetic heavies were not X-rayed; they probably include Cpx. and Amph. }\end{array}$} \\
\hline & & $\begin{array}{l}\text { Plag. composition is uncertain, but definitely sodic; } \\
\text { the rock is hawaiite or even more differentiated. }\end{array}$ & $\begin{array}{l}\text { PLAG.; peak separations uncertain because } \\
\text { of interferences, but appear to be: } \\
\Delta 2 \theta=1.51^{\circ} ; \text { max. An content }=\mathrm{An}_{2} 1 \\
\Gamma \quad=+0.21^{\circ} ; \text { max. An content }=\mathrm{An}_{33} \\
\text { CHAB. } \\
\text { GMEL. } \\
\text { K-fld. }\end{array}$ \\
\hline & & 15 mole $\%$ Us if it lies on the Us-Mt. join & $\begin{array}{l}\text { Titanomagn. }\left(\mathrm{a}_{\mathrm{O}}=8.405 \AA\right) \\
\text { ilm. } \\
\text { mont. }\end{array}$ \\
\hline \multirow[t]{2}{*}{$27-2,60-65 \mathrm{~cm}$} & Vein & $\begin{array}{l}\text { White, about } 0.5 \mathrm{~mm} \text { thick; minor yellow sulfides } \\
\text { with triangular faces; the thom. X-ray pattern has } \\
\text { some features indicative of natr.; the mineral is } \\
\text { perhaps a transitional type of zeol. }\end{array}$ & $\begin{array}{l}\text { THOM., CALC., PYRITE.; Minor Mont.; } \\
\text { trace chl., gmel. }\end{array}$ \\
\hline & Sulfide & $\begin{array}{l}\text { Concentrated mainly from a vein, but also from the } \\
\text { host rock }\end{array}$ & PYRITE; Minor calc.; trace thom., gmel. \\
\hline \multirow[t]{7}{*}{$27-\mathrm{CC}$} & Basalt & $\begin{array}{l}\text { Total rock sampled as far as possible from an } \\
\text { exposed joint surface coated with pyrite and brown } \\
\text { calc. "SCOLECITE" and Thom. peaks are not } \\
\text { exactly right. }\end{array}$ & $\begin{array}{l}\text { CPX., AMPH., "SCOLECITE"; Minor Plag., } \\
\text { Ilm., Thom.; trace mica., mont., apat.(?), } \\
\text { K-fld., gmel.(?) }\end{array}$ \\
\hline & Basalt & $\begin{array}{l}\text { Same mount after exposure to ethylene glycol } \\
\text { vapors for } 1 \text { day; the "scolecite" peaks are gone; } \\
\text { the thom. peaks remain, but in many ways resemble } \\
\text { those of natr. }\end{array}$ & Same but no "scolecite" \\
\hline & Basalt & $\begin{array}{l}\text { Total rock taken as above as far as possible from the } \\
\text { coated joint; evidently the rock is modally very } \\
\text { variable on a local scale. The "thom." is much more } \\
\text { like natr. than like thom. }\end{array}$ & $\begin{array}{l}\text { Same + trace gmel. (and chab.??); no } \\
\text { "scolecite"; "thom." much reduced, amph. } \\
\text { relatively increased }\end{array}$ \\
\hline & \multicolumn{3}{|c|}{ Density fractions of a specimen sampled as above: } \\
\hline & & $\begin{array}{l}\text { Two lightest fractions; the X-ray pattern of natr. is } \\
\text { relatively clear; it is definitely that of natr. and not } \\
\text { thom. }\end{array}$ & CHAB., GMEL., NATR.; Minor Plag., K-fld. \\
\hline & \multicolumn{3}{|c|}{ Density fractions of a sample the exact location of which was not recorded: } \\
\hline & & $\begin{array}{l}4 \text { lightest fractions; apparently both natr. and thom. } \\
\text { or some intermediate type of zeol. is present. }\end{array}$ & $\begin{array}{l}\text { GMEL., CHAB., NATR., THOM.; Minor } \\
\text { K-rich plag., K-fld., calcic anorthoclase }\end{array}$ \\
\hline \multirow[t]{3}{*}{ 27-CC } & Basalt & $\begin{array}{l}\text { Total rock, from near pyrite-calcite-coated joint; } \\
\text { natr. may in fact be thom. Apparently the rock near } \\
\text { the joint is definitely richer in gmel., chab. and mont. } \\
\text { than the rock farther away (compare results above). }\end{array}$ & $\begin{array}{l}\text { GMEL., CHAB., MONT., AMPH., PLAG., } \\
\text { NATR., CPX. }\end{array}$ \\
\hline & \multicolumn{3}{|c|}{$\begin{array}{l}\text { Density and magnetic fractions of basalt from near the coated joint: (this sample may have been mixed up with } \\
17-27-2,60-65 \mathrm{~cm} \text {; see above); }\end{array}$} \\
\hline & & Definitely natr., not thom. & $\begin{array}{l}\text { CHAB. } \\
\text { GMEL. } \\
\text { NATR. }\end{array}$ \\
\hline
\end{tabular}


APPENDIX A - Continued

\begin{tabular}{llll}
\hline Specimen & Rock Type & Comments & Mineralogy (X-Ray) \\
\hline
\end{tabular}

Hole 165A - Continued

27-CC

\section{Site 166}

\section{$29-2,16-25 \mathrm{~cm}$}

Basalt

Basalt

Altered glass

Red joint filling

Deep brown joint filling

$29-2,121-123 \mathrm{~cm}$

\section{$29-3,72-74 \mathrm{~cm}$}

$29-3,83-90 \mathrm{~cm}$

Calc. from vugs

Basalt

Outer zone of vein

Calc. from vugs
Plag. is sodic; however, it represents only the rims; the bulk is replaced by zeol. (see petrography); these data alone, therefore, do not allow the conclusion that the rock is hawaiitic

12 mole $\%$ Us if on the Us-Mt join
PLAG.; peak separations are uncertain because of interferences, but appear to be: $\left.\Delta 2 \theta=1.68^{\circ}\right\}$ Max. An content $\left.\Gamma=+0.37^{\circ}\right\}=$ An $37-51$ AMPH.

CPX.

Titanomagn. $\left(\mathrm{a}_{\mathrm{O}}=8.402 \AA\right)$

Ilm.

Mica

K-fld.

chl.

pyrite?

mont.

PLAG., CPX; Minor Mont.

PLAG., CPX.; Minor Mont.; trace K-fld.

Total rock; relatively "fresh" interior well below glassy selvage; medium gray, with brownish tinge. CPX. verges toward subcalcic augite.

Light gray, faintly brownish, resinous, soft "layered" or laminated structure which outlines small blocks may be relict from a former palag. stage of alteration. Cut by orange brown seams of palag.

Orangish yellow brown streak; from moderately to steeply dipping joints just below the glassy selvage; near the glass the red material is interlayered with calc. which decreases downward (away from the glass). Downward the red grades to deep brown joint fillings (see below)

Flaky; yellow brown streak; occurs below (i.e., farther from glassy selvage) red joint fillings (see above)

Light brown veins Parallel-walled, light brown or amber veins which cut PHIL.; trace mont., calc. plus minor greenish fragments of altered glass in a calcite-cemented gray altered glass hyaloclastite breccia. Fragments in the breccia are composed mainly of glass altered to dark, gray or greenish gray material which encloses concentrically zoned spherulites; there are also minor fragments of fresh-looking sideromelane. The mont. is poorly crystallized, as is true of mont. in all samples of altered glass from Leg 17 (compare 29-2, 16-25 cm above; and 169-12-2, 115-117 cm, and 171-27-1, $133-142 \mathrm{~cm}$ )

From vug in cement of hyaloclastite breccia; the crystals are shaped like "cones" (rhombs?) and striated radially; they may be "dog-tooth" crystals with abundant vicinal faces; this morphology is common in vuggy calc. from buried oceanic basalt (e.g., basalt from the Experimental Mohole)

Total rock

Green and yellow green (weathered) material along one side of a (goet. + calc.) vein. Probably corresponds to celad. seen in thin section as selvages on veins; some of the vein material in 29-2-16 to 25 cm may also be celad. (see above)
MONT. (poorly crystallized); trace plag., calc.

GOET.; trace calc., mont. (?-or possibly mica; see $17-166-29-3-72$ to $74 \mathrm{~cm}$ )

GOET.; trace calc.

CALC. (3.5 mole $\left.\% \mathrm{MgCO}_{3}\right)$

PLAG., CPX.; Minor Mont.

CALC., CELAD.

CALC. $\left(1.0\right.$ to 3.0 mole $\% \mathrm{MgCO}_{3}$, average about 2 mole \%; broad range of composition)
From mass of calc. which encloses isolated pieces of altered basalt glass. Calc. is mainly light reddish brown, with minor white and gray; vugs are partly to wholly filled with gray, gray green or brown mont. 


\begin{tabular}{llll}
\hline Specimen & Rock Type & Comments & Mineralogy (X-Ray) \\
\hline
\end{tabular}

Site 166 - Continued

$29-3,83-90 \mathrm{~cm}$

29-CC

Basalt

Green selvages of calc. veins

Deep green joint fillings

Magnetic heavy minerals

Nonmagnetic heavy minerals
Vermicular deep gray green crystals on crystal faces of calc. in partially filled vugs. The mont. is wellcrystallized and Na-saturated

Total rock. The anat. peak is distinct but anat. would be unusual in the abundance indicated, especially in view of the absence of a distinct anat. peak in the pattern of the magnetic heavy minerals (see below). Celad. is seen in thin section in the groundmass; the absence of a $10 \AA \mathrm{X}$-ray peak suggests that the celad. is a $1 \mathrm{Md}$ type, and probably not abundant. The mont. is is $\mathrm{Na}$-saturated.

Thin, very minor in the rock

Thin, very minor in the rock; calc. is locally interlayered, but is generally absent. Both Na-saturated and non-Na-saturated types of mont appear to be present.

Rock finely ground in agate mortar, centrifuged; sample is denser than $\mathrm{MeI}_{2}$ and magnetic; anat. peak is weak and indistinct; it is present in trace amounts at most; no ilm.

As above, but nonmagnetic. No anatase or ilm.

\section{Site 167}

$94-2,137-140 \mathrm{~cm}$

Plag.

$94-3,78-84 \mathrm{~cm}$

Calc.

Calc.

Magnetic heavy minerals

Plag.

Plag in thin section

94-CC(a)

Green chert

Red chert

Mont. clasts in breccia
Interior of large phenocryst or xenocryst with dark green reaction rim (probably diagenetic) and tiny dark inclusions (probably groundmass formed by hollow growth or by reaction and resorption in the magma). The visible part of the crystal at the edge of the sawed block is $12 \times 9 \times 7 \mathrm{~mm}$. K-fld. is probably a diagenetic replacement product, as in mont.

"Dirty" calc. mass with radial internal structure, embedded in $2 \mathrm{~cm}$ ovoid of mont. (this mont. is part of that separated for chemical analysis). The dirtiness is due to inclusions, presumably of mont., which are especially concentrated at the centers of the radiating structures.

White structureless masses from the same $2 \mathrm{~cm}$ ovoid as above without the inclusions and radial internal structure

Separated from the crushed rock with a hand magnet. TITANOMAGN. $\left(\mathrm{a}_{\mathrm{O}}=8.412 \AA\right)$; trace cps., The titanomagn. is Us 22 if it is on the Us-Mt join.

Separated during purification of mont. for chemical analy sis

Compositions of ordinary (nonphenocrystic) grains estimated from Carlsbad-Albite twin combinations

Green part of green chert mottled with red. Apparently unoxidized

Red part of green chert mottled with red. Apparently the red color is due to oxidation of pyrite to hem.

Two dark gray, massive, structureless, subrounded clasts, free of calc. cement, but containing tiny vitreous grains and minor white surface powder which may be $\mathrm{NaCl}$.
MONT.; Minor Calc.

PLAG., CPX.; Minor Mont.; trace anat., K-fld (?)

CALC.; trace mont., mica(?)

CELAD., MONT.; Minor Calc.

MAGHEM. (or, more properly, MAGHEMO-

MAGN.; $\left.a_{o}=8.380 \AA\right)$; trace cpx., anat.(?)

SUBCALCIC AUGITE; Minor Plag.; trace mont.

PLAG.; Minor K-fld.; trace mont., zeolite, 7 A mineral (phillipsite?)

$\Delta 2 \theta=2.25^{\circ} ;$ An93

$\Gamma=+1.43^{\circ}$; An91-94

Refractive indices of cleavage flakes from the interior of the plag indicate a range of compositions, with extremes as follows:

$\mathrm{X}^{\prime}=1.570 ; \mathrm{An} 80$

$Z^{\prime}=1.581 ;$ An90-91

CALC. $\left(0.5\right.$ mole $\left.\% \mathrm{MgCO}_{3}\right)$

CALC. $\left(0.5^{-}\right.$mole $\left.\% \mathrm{MgCO}_{3}\right)$ anat.

PLAG. $\Delta 2 \theta=1.99^{\circ} ; \Gamma=+0.93^{\circ}$

Composition more sodic than $A n 70$ and probably in the range An 53-70

1) core $\mathrm{An}_{67}$; rim $\mathrm{An}_{53}$

2) core $\mathrm{An}_{66}$

QUAR., PYRITE; Minor Calc.; trace mont., apat.

QUAR.; Minor Calc.; trace plag., hem.. mont., apat.

MONT.; Minor Calc.; trace quar. 


\begin{tabular}{|c|c|c|c|}
\hline Specimen & Rock Type & Comments & Mineralogy (X-Ray) \\
\hline \multicolumn{4}{|c|}{ Site 167 - Continued } \\
\hline \multirow[t]{2}{*}{ 94-CC(b) } & Basalt & Total rock & PLAG., CPX., MT., MONT.; trace K-fld. \\
\hline & $\begin{array}{l}0.3 \mathrm{~mm} \\
\text { phenocryst }\end{array}$ & Dark, vitreous, anhedral, apparently pyroxene & AUGITIC CPX. \\
\hline $95-2,40-43 \mathrm{~cm}$ & Basalt & $\begin{array}{l}\text { Total rock; K-fld. observed in thin section to } \\
\text { replace cores of large plag. phenocrysts }\end{array}$ & PLAG., CPX., MONT., MT.; trace K-fld. \\
\hline \multirow[t]{3}{*}{$95-2,99-100 \mathrm{~cm}$} & $\begin{array}{l}\text { Dark green flakes } \\
\text { lining cavity in } \\
\text { gray part of } \\
\text { basaltic breccia }\end{array}$ & $\begin{array}{l}\text { Breccia is mainly brownish gray, but is medium to } \\
\text { light green on one side. Minor calc. patches are } \\
\text { present. Cavities and joints in the gray part are } \\
\text { lined or filled with medium to dark green fiaky } \\
\text { material. Note: the breccia is not hyaloclastic; the } \\
\text { clasts are largely crystalline basalt }\end{array}$ & $\begin{array}{l}\text { MONT. (well crystallized); Minor mixed- } \\
\text { layer Mont.-Chl.; trace plag., calc. }\end{array}$ \\
\hline & $\begin{array}{l}\text { Darker parts of } \\
\text { medium to light } \\
\text { green part of } \\
\text { breccia, plus simi- } \\
\text { larly colored green } \\
\text { seams traversing } \\
\text { the adjacent gray } \\
\text { part of breccia }\end{array}$ & $\begin{array}{l}\text { From same breccia as above; no mixed-layer } \\
\text { phase is present }\end{array}$ & CELAD., MONT.; Minor Calc.; trace plag. \\
\hline & $\begin{array}{l}\text { Largest clast in } \\
\text { gray part of } \\
\text { breccia }\end{array}$ & Total rock; brownish gray basalt clast & $\begin{array}{l}\text { PLAG., CPX., MONT. } \\
\text { For plag.: } \Delta 2 \theta=1.94^{\circ} ; \Gamma=+0.80^{\circ} \\
\text { Composition more sodic than } \mathrm{An}_{68}\end{array}$ \\
\hline \multirow[t]{3}{*}{$95-2,127-128 \mathrm{~cm}$} & $\begin{array}{l}\text { Dark green massive } \\
\text { clast in breccia }\end{array}$ & $\begin{array}{l}\text { Angular, structureless, conchoidal, soft, brittle, } \\
\text { crunchy; probably altered glass }\end{array}$ & 1M CELAD.; trace mont., calc. \\
\hline & $\begin{array}{l}3 \text { light green } \\
\text { massive clasts }\end{array}$ & $\begin{array}{l}\text { Angular to rounded, conchoidal, structureless, soft; } \\
\text { brittle and crunchy, but less so than the dark green } \\
\text { clast (see above). }\end{array}$ & $\begin{array}{l}\text { MONT.; Minor } 1 \mathrm{M} \text { or } 1 \mathrm{Md} \text { Celad.; } \\
\text { trace calc. }\end{array}$ \\
\hline & $\begin{array}{l}\text { Brown tarnished } \\
\text { sulfide }\end{array}$ & Concentrated along edge of calc. ovoid & PYRITE \\
\hline \multirow[t]{2}{*}{$95-\mathrm{CC}$} & $\begin{array}{l}\text { Dark green patch } \\
\text { in basalt }\end{array}$ & $\begin{array}{l}\text { Grades out to surrounding basaltic host; rock } \\
\text { reacts strongly to magnet. }\end{array}$ & CELAD., MONT.; trace calc. \\
\hline & Yellow sulfide & $\begin{array}{l}\text { Several grains pried out of the groundmass of the } \\
\text { basalt with a needle. }\end{array}$ & PYRITE \\
\hline \multicolumn{4}{|l|}{ Site 169} \\
\hline \multirow[t]{4}{*}{$5-1,21-24 \mathrm{~cm}$} & $\begin{array}{l}\text { Diabase or coarse } \\
\text { basalt, near top of } \\
\text { sill, but probably } \\
\text { not the chilled } \\
\text { upper surface itself } \\
\text { (contrast chilled } \\
\text { lower contact; see } \\
\text { below). }\end{array}$ & $\begin{array}{l}\text { Total rock; fine-grained; finer grained than bulk of } \\
\text { sill, but not chilled; brownish, somewhat altered, } \\
\text { rusty along joints. }\end{array}$ & $\begin{array}{l}\text { PLAG., CPX., K-FLD., CHL.; trace ilm. (?- } \\
\text { see magnetic heavies below), mont. } \\
\text { For plag.: } \Delta 2 \theta=1.91^{\circ} ; \Gamma=+0.75^{\circ} \\
\text { Composition more sodic than } \mathrm{An}_{65}\end{array}$ \\
\hline & $\begin{array}{l}\text { Magnetic heavy } \\
\text { minerals }\end{array}$ & $\begin{array}{l}\text { Separated from crushed rock by centrifuging in } \\
\text { MeI } 2 \text {; no ilm., the "ilm." peak in the total rock } \\
\text { pattern (see above) is probably a mistakenly iden- } \\
\text { tified K-fld. peak; Presence of Maghem. indicates } \\
\text { diagenetic alteration and suggests that K-fld. is } \\
\text { diagenetic, not deuteric or hydrothermal. }\end{array}$ & MAGHEM. $\left(\mathrm{a}_{\mathrm{O}}=8.366 \AA\right)$; trace anat. \\
\hline & Density fractions of & crushed rock obtained during purification of $\mathrm{K}$-fld for & age determination: \\
\hline & & $\begin{array}{l}\text { Monoclinic or very low triclinicity Age is } 58 \pm 2 \mathrm{~m} . \mathrm{y} \text {. } \\
\text { (R. L. Armstrong; K in duplicate }=1.01 \% \text { and } \\
0.975 \% ; 40 \mathrm{Ar} *=2.33 \times 10^{-6} \mathrm{cc} \mathrm{STP} / \mathrm{gram} ; 73 \% \\
\text { atmospheric Ar correction). This is an integrated } \\
\text { average age for the time of a diagenetic alteration } \\
\text { and a younger age limit for the sill }\end{array}$ & $\begin{array}{l}\text { PLAG. } \\
\text { CHL. } \\
\text { mont. } \\
\text { phil. }\end{array}$ \\
\hline
\end{tabular}


APPENDIX A - Continued

\begin{tabular}{|c|c|c|c|}
\hline Specimen & Rock Type & Comments & Mineralogy (X-Ray) \\
\hline \multicolumn{4}{|c|}{ Site 169 - Continued } \\
\hline $5-1,122-124 \mathrm{~cm}$ & Diabase & Total rock; no K-fld. seen in thin section. & $\begin{array}{l}\text { PLAG., CPX.; Minor Chl., Mont.; } \\
\text { trace mt. }\end{array}$ \\
\hline \multirow[t]{3}{*}{$6-1,63-70 \mathrm{~cm}$} & Olivine & $\begin{array}{l}\text { Concentration of light brown, vitreous, transparent } \\
\text { olivine pried out with a needle. }\end{array}$ & $\begin{array}{l}\text { OL; } d_{(130)}=2.786 \AA, F_{070} ; \text { peak } \\
\text { skewed to Fe-rich side, with possible second } \\
\text { peak at } d_{(130)}=2.808 \AA, F_{37} \text {, but it is } \\
\text { very uncertain }\end{array}$ \\
\hline & Vein & $\begin{array}{l}\text { Horizontal, bluish gray, dense, massive, soft, sectile; } \\
\mathrm{CHL} \text {. is } \mathrm{Mg} \text {-rich; mixed-layer phase has variable } \\
\text { ratios of Chl. to Mont. }\end{array}$ & CHL., SERP.; Minor mixed-layer Chl. Mont. \\
\hline & Calc. "vein" & $\begin{array}{l}\text { Joint with discontinuous, irregular patches of calc.; } \\
\text { rock on either side of joint is dark gray, altered, } \\
\text { similar to altered rock on either side of natr. vein } \\
\text { in } 6-4-88-92 \mathrm{~cm} \text { (see below) }\end{array}$ & \\
\hline \multirow[t]{4}{*}{$6-2,19-20 \mathrm{~cm}$} & Diabase & $\begin{array}{l}\text { Medium-grained, fresh, no veins, of the coarsest } \\
\text { parts of the sill. }\end{array}$ & $\begin{array}{l}\text { PLAG., CPX.; Minor Chl.; trace chab., } \\
\text { pyrite(?), alk. fld?, mont. } \\
\text { For plag.: } \Delta 2 \theta=1.86^{\circ} ; \Gamma=+0.70^{\circ} \\
\text { Composition more sodic than } \mathrm{An}_{64}\end{array}$ \\
\hline & Olivine & $\begin{array}{l}\text { Light brown, transparent, vitreous, seamed by } \\
\text { brown and black mont.; pried out with a needle }\end{array}$ & OL.; $d_{(130)}=2.785 \AA, F_{071}$ \\
\hline & $\begin{array}{l}\text { Zeolite-rich } \\
\text { interstitial patch }\end{array}$ & $\begin{array}{l}\text { Milk white, translucent, radial internal structure } \\
\text { locally; chiseled out of the rock. There may be a } \\
\text { second plag.; the more sodic one is less abundant } \\
\text { and may coexist with phil. in late interstitial patch. }\end{array}$ & $\begin{array}{l}\text { PHIL., PLAG.; trace mont. } \\
\text { For plag.: } \Delta 2 \theta=2.04^{\circ} ; \Gamma=+0.86^{\circ} \\
\text { Composition is in the range An } 46-73 \text { and } \\
\text { probably in the range } \mathrm{An}_{60-73}\end{array}$ \\
\hline & Plag. & $\begin{array}{l}\text { Concentration of plag. pried out of rock well away } \\
\text { from zeolite-rich patches. Apparently plag. is partly } \\
\text { replaced by zeol. throughout the sill, as seen by } \\
\text { abundant, low-index veins and patches in plag. } \\
\text { in most thin sections. }\end{array}$ & $\begin{array}{l}\text { PHIL., PLAG.; trace chab., mont. } \\
\text { For plag.: } \Delta 2 \theta=1.94^{\circ} ; \Gamma=+0.75^{\circ} \\
\text { Composition more sodic than } \mathrm{An}_{65}\end{array}$ \\
\hline $6-2,37-39 \mathrm{~cm}$ & Vein & $\begin{array}{l}\text { Horizontal, light to medium gray to light grayish } \\
\text { green; } 0.5 \mathrm{~mm} \text { thick, but is discontinuous and } \\
\text { pinches and swells; soft, sectile, apparently has } \\
\text { cross fiber structure. }\end{array}$ & $\begin{array}{l}\text { SERP., CHL.; Minor Mont., mixed-layer } \\
\text { Chl.-Mont. }\end{array}$ \\
\hline \multirow[t]{2}{*}{$6-3,33-38 \mathrm{~cm}$} & $\begin{array}{l}\text { Magnetic heavy } \\
\text { minerals }\end{array}$ & $\begin{array}{l}\text { Separated by centrifuging the crushed rock in } \mathrm{MeI}_{2} \text {; } \\
\text { the rock is the freshest specimen from the sill. No } \\
\text { anat. or ilm. is present; the titanomagn. is Us } 61 \text { if } \\
\text { it lies on the Us-Mt join. }\end{array}$ & TITANOMAGN. $\left(\mathrm{a}_{\mathrm{O}}=8.466 \AA\right)$ \\
\hline & Calc. & Flaky coating on joint surface in diabase & CALC. (2.5 mole $\left.\% \mathrm{MgCO}_{3}\right)$ \\
\hline \multirow[t]{3}{*}{$6-4,88-92 \mathrm{~cm}$} & Diabase & $\begin{array}{l}\text { Fresh, medium-grained, } 2.5 \mathrm{~cm} \text { from natrolite vein; } \\
\text { no K-fld.; the ilm. X-ray peak is conceivably an alk } \\
\text { fld. peak; there is no evidence for ilm. in any heavy } \\
\text { mineral separate. }\end{array}$ & $\begin{array}{l}\text { PLAG., CPX., CHL.; trace chab., ilm., } \\
\text { mont., alk. fld.? } \\
\text { For plag.: } \Delta 2 \theta=1.98^{\circ} ; \Gamma=+0.89^{\circ} \\
\text { Composition in the range An } 49-71\end{array}$ \\
\hline & Vein & $\begin{array}{l}\text { Dense, white, discontinuous; adjacent diabase is } \\
\text { dark and fine-grained (finer than surrounding dia- } \\
\text { base); contains scattered yellow sulfide grains, and } \\
\text { is apparently altered. }\end{array}$ & $\begin{array}{l}\text { NATR., CHL.; Minor Mont. (and/or mixed- } \\
\text { layer Chl.-Mont.?); trace calc. }\end{array}$ \\
\hline & Yellow sulfide & $\begin{array}{l}\text { Concentration pried out of altered rock next to the } \\
\text { natr. vein. }\end{array}$ & PYRITE, MONT.; trace calc., plag. \\
\hline \multirow[t]{2}{*}{$6-4,140-141 \mathrm{~cm}$} & Diabase & $\begin{array}{l}\text { Total rock; medium-grained; no K-fld. or zeol.; plag. } \\
\text { may be more sodic than in rest of sill to judge from } \\
\text { X-ray peak separations, but this is very uncertain. }\end{array}$ & $\begin{array}{l}\text { PLAG., CPX., CHL.; trace mont., mixed- } \\
\text { layer chl.-mont., ilm.?-see below) } \\
\text { For plag.: } \Delta 2 \theta=1.82^{\circ} ; \Gamma=+0.56^{\circ} \\
\text { Composition more sodic than An59 }\end{array}$ \\
\hline & $\begin{array}{l}\text { Magnetic heavy } \\
\text { minerals }\end{array}$ & $\begin{array}{l}\text { Separated by centrifuging the crushed rock in } \mathrm{MeI}_{2} \\
\text { no anat. or ilm.; the titanomagn. is Us } 60 \text { if it lies } \\
\text { on the Us-Mt join; bread ths of peaks suggest slight } \\
\text { range of composition. }\end{array}$ & TITANOMAGN. $\left(\mathrm{a}_{\mathrm{O}}=8.464 \AA\right)$ \\
\hline $6-5,141-144 \mathrm{~cm}$ & Basalt & $\begin{array}{l}\text { Greenish gray, very-fine-grained, about } 3 \mathrm{~cm} \text { above } \\
\text { lower contact of sill. The ilm? peak may be a } \\
\text { mistakenly identified K-fld. peak. }\end{array}$ & $\begin{array}{l}\text { PLAG., K-FLD., CPX., CHL., MONT.; } \\
\text { Minor Amph., Calc.; trace mixed-layer } \\
\text { chl.-mont., ilm.? } \\
\text { For plag.: } \Delta 2 \theta=2.02^{\circ} ; \Gamma=+0.98^{\circ} \\
\text { Composition in the range An } 57-74\end{array}$ \\
\hline
\end{tabular}




\begin{tabular}{|c|c|c|}
\hline Specimen & Rock Type & Comments \\
\hline \multicolumn{3}{|c|}{ Site 169 - Continued } \\
\hline \multirow[t]{2}{*}{$6-5,141-144 \mathrm{~cm}$} & $\begin{array}{l}\text { Magnetic heavy } \\
\text { minerals }\end{array}$ & $\begin{array}{l}\text { Separated from crushed rock, taken about } 3 \mathrm{~cm} \\
\text { above lower contact of sill, by centrifuging in } \mathrm{MeI}_{2} \text {. } \\
\text { Titanomagn. is like that in interior of sill; it is Us } 58 \\
\text { if it lies on the Us-Mt join. The magn. is more } \\
\text { abundant than titanomagn. and is almost pure (see } \\
\text { unit cell edge). It suggests oxidation, but unlike the } \\
\text { diagenetic oxidation at the top contact which pro- } \\
\text { duced maghem. and anat.; the oxidation may have } \\
\text { been deuteric, under conditions which also led to } \\
\text { crystallization of abundant amphibole (see below). }\end{array}$ \\
\hline & Basalt & $\begin{array}{l}\text { Greenish gray, very fine-grained, as above, but only } \\
\text { about } 1 \mathrm{~cm} \text { above lower contact of sill. K-fld. may } \\
\text { be diagenetic, but the Amph. is unlikely to be so. } \\
\text { The increase of Amph. downward in the bottom } \\
3 \mathrm{~cm} \text { of the sill suggests that it crystallized in the } \\
\text { moderately chilled zone near (but not at) the bot- } \\
\text { tom contact of the sill as it absorbed water from } \\
\text { the underly ing sediments; oxidation related to this } \\
\text { water may have controlled formation of magn. } \\
\text { (see above). }\end{array}$ \\
\hline
\end{tabular}

Mineralogy (X-Ray)

MAGN. $\left(\mathrm{a}_{\mathrm{O}}=8.395 \AA\right)$

TITANOMAGN. $\left(\mathrm{a}_{\mathrm{O}}=8.461 \AA\right)$
PLAG., CPX., CHL., MONT., AMPH. K-FLD.: Minor Calc.; trace mixed-layer chl.-mont.

Basalt: chilled, dark gray to black base of sill, about 3 to $4 \mathrm{~mm}$ thick, originally perhaps glassy, composed of two distinct lithologies which are locally interlayered: (1) dense, dark gray, massive; and (2) dense, light gray, locally laminated or streaky material which may originally have been flow-banded glass. Dense black material similar to (1) is enclosed in, or convoluted with, a large patch of medium- to coarse-grained (recrystallized?) calc. at the contact. The $45^{\circ}$ dip of the contact suggests an irregular contact which bulges into the underlying sediments; this fact in turn suggests that the sediments were soft and plastic when the sill was intruded.

Basalt (1)

Basalt (2)

Basalt

$11-1,84-85 \mathrm{~cm}$

$11-\mathrm{CC}$

Basalt

Basalt

Vein calc.

Celad. patches

$12-1,31-32 \mathrm{~cm}$

Vein; emphasizes green selvage along one side

Dark green patch
Dense, dark gray, massive altered glass (?). No mixed-layer chl.-mont.

Dense, light gray, locally laminated or streaky, altered glass(?). No mixed-layer chl.-mont.; apparently formation of mixed-layer minerals was favored by high temperature and slow cooling in the less chilled interior of the sill.

Dense, black, chilled basalt in large calc. patch at lower contact; very similar to basalt (1). No chl. or mixed-layer chl.-mont.; apparently chilled too fast for them to form.

White and green laminated vein which cuts finegrained basalt; X-rayed sample selected from green material along one side.

Along projections of vein-filled cracks in the finegrained basalt are areas rich in irregularly distributed white calc. patches; the veins terminate without cutting these areas. In one of them is a single, irregular, dark green patch or "amygdule"; otherwise green material is very minor in the white patches.

Total rock; fine-grained. No chl.

Total rock. No chl.

Veins up to $2 \mathrm{~mm}$ thick with continuous or discontinuous walls of deep blue green celad.; minor dark gray mont.(?) in some calc. veins.

Deep blue green pockets in host rock, some of which enclose light reddish brown material. Pockets may be altered late interstitial residuum of the basalt, or possibly amygdules. Celad. is fairly well crystallized (1M rather than $1 \mathrm{Md}$ to judge from distinct $10 \AA$ peak).

Total rock; no chl.
MONT., PLAG.; Minor Cpx., K-fld., Pyrite (?).; trace mica, calc.

For plag.: $\Delta 2 \theta=2.01^{\circ} ; \Gamma=+0.97^{\circ}$

Composition in the range An 55-74

MONT., PLAG., K-FLD., CPX.; Minor

Amph., pyrite(?), Chl.; trace calc., chab.

PLAG., CPX., MONT.; Minor calc.; trace mica

CALC., CELAD.; Minor Mont.

CELAD. (1Md); trace calc.

PLAG., CPX.; Minor Mont.

PLAG.; CPX.; Minor Mont.; trace K-fld.

CALC. (1.0 mole $\left.\% \mathrm{MgCO}_{3}\right)$; trace celad.

CELAD. (1M); trace calc., mont.

PLAG., CPX.; trace mont., K-fld. 


\begin{tabular}{lll}
\hline Specimen & Rock Type & Comments \\
\hline Site $169-$ Continued &
\end{tabular}

Basalt with glassy selvage edge of pillow? Cut by veins. Glass selvage retains fresh sideromelane in inner part, most of which is altered to green and to lesser grayish brown, soft, resinous material. Color laminations in green altered glass outline blocks, probably relict from color-laminated palag. blocks. Grayish brown alteration occurs mainly in the interiors of such blocks. Veins in the inner, crystalline part of the specimen are zoned with calc. and green selvages. In the glassy selvage the veins are parallel to the dip of the selvage, lack green outer zones, and range in color from translucent gray to colorless. Spherulites occur in some sideromelane, but are rare in the altered glass.

Green altered glass

Colorless, glassy vein in altered glass

The Cpx. may represent relict spherulites; it may be pigeon., but the X-ray pattern is not distinct. The phil. is probably from a vein.

Parallel to dip of glassy selvage; grades along length to white or gray translucent vein; brown to greenish brown altered glass contamination in the $\mathrm{X}$-rayed sample. No calc.

Laminated white From crystalline basalt below the glassy selvage. and green vein; emphasizes green selvages
MONT.; Minor Cpx.; trace plat., phil.

PHIL.; Minor Mont., Cpx.; trace plag.

CALC., CELAD.; trace mont.

Chilled, dense, gray basalt with altered glassy selvage; cut by dense network of calc. veins ( 2 to $3 \mathrm{~mm}$ thick) which locally enclose angular basalt fragments as in a calcite-cemented interpillow breccia. The glassy selvage is altered to green, light brown and dark gray, resinous, mont. material. It grades inward through a zone of isolated gray spherulites in altered glass, to a layer of continuous spherulites with interstitial brown altered glass, to gray microcrystalline basalt. A rapidly tapering projection of green to dark gray altered glass(?) extends inward along one wall of a glassy phil.(?) vein into the spherulite layer. The vein is composed of phil.(?) within the altered glass selvage, but gives way in the spherulite layer to a deep green celad.(?) vein that continues into the chilled crystalline basalt. In the isolated basalt fragments some joint surfaces are coated by red $\mathrm{Fe}$ oxide. In the spherulite layer are tiny irregular patches of highly shattered, transparent, light bottle green material resembling olivine microphenocrysts, which may be mont. pseudomorphs after olivine.

Green altered

glass with isolated gray spherulites

Green patches in spherulite layer

Mont. in calc. vein

Coarse vein calc.

Mont. selvage of vein

Essentially a "green palag."; either the alteration has not produced much mont., or that which formed is very poorly crystallized. It is not known whether the plag. is in the spherulites or occurs as microphenocrysts; the pigeon. is undoubtedly in the spherulites.

Light bottle green, soft, transparent, shattered; apparently not amygdules; may be altered olivine microphenocrysts or altered interstitial glass like the green alteration products of the outer glassy selvage of the specimen. The $\mathrm{Cpx}$. is probably contamination from the spherulites; therefore the green material is probably either amorphous or very poorly crystallized (compare green altered glass above).

Deep gray mass enclosed in vein in dense system of cross-cutting or anastomosing calc. veins. Mont. is well crystallized (contrast altered glass above) and composed of distinct Na-saturated and non-Nasaturated types.

Large colorless crystals near the edge of the same vein that encloses the mass of deep gray mont. above. The large colorless crystals apparently are purer $\mathrm{CaCO}_{3}$ than the finer grained bulk of the veins.

Lens of black mont. along wall of the same vein from which above samples were taken; occurs immediately adjacent to the large colorless calc. crystals. The mont. is well-crystallized (contrast altered green glass above) and composed of distinct $\mathrm{Na}$-saturated and non-Na-saturated types; the Na-saturated type is greatly dominant.

Mont. lenses along Dark gray lenses about one inch below the glass seljoint + calc. vein with green selvages
PIGEON. (or subcalcic augite); trace plag., mont.

CPX.; and AMORPHOUS MATERIAL?

MONT., CALC. $\left(0.5\right.$ or 1.0 mole $\left.\% \mathrm{MgCO}_{3}\right)$

CALC. $\left(0 \% \mathrm{MgCO}_{3}\right)$

MONT., CALC.

MONT., CALC., CELAD. vage; soft, crunchy; the joint projects into a calc. vein with green selvages. The mont. is well-crystallized (contrast the green altered glass above) and composed of distinct Na-saturated and non-Nasaturated types. 
APPENDIX A - Continued

\begin{tabular}{llcc}
\hline Specimen & Rock Type & Comments & Mineralogy (X-Ray) \\
\hline
\end{tabular}

\section{Site 170}

$10-\mathrm{CC}$

$16-1,17-24 \mathrm{~cm}$

$16-1,24-37 \mathrm{~cm}$

Coating of outer surface of specimen and linings of vesicles

Basalt, relatively dark altered rim of specimen

Basalt, relatively lighter colored, fresher interior of specimen

Blue greenish gray basalt

Blue greenish gray basalt

Magnetic heavy minerals

Celad.

Patch composed of earthy brown and resinous deep green materials
Green to yellow green, vermicular material from the outer surface and from walls of the larger vesicles; it may be an alteration product or adhering sediment. The plag. is contamination from the drusy walls of the vesicles. The mont. is dioctahedral $\left(\mathrm{d}_{(060)}=1.51 \AA\right)$ and Na-saturated.

Total rock; chilled, fresher and finer grained than basalts from deeper in this site. Variously interpreted as a sill or flow, or as clasts in a gravelly turbidite. The mont. is Na-saturated.

Total rock; no K-fld., anat. or ilm. as in alkaline rocks from Hole 165A. Both Na-saturated and non-Na-saturated types of mont. are present.

Total rock; celad. replaces groundmass and, with or without calc., fills ovoids of uncertain origin; they do not appear to be vesicles.

Total rock; from upper, relatively chilled, finer grained part which, in thin section, is seen to contain brown, moderately pleochroic amphibole; crystallization of the amphibole may have been controlled by water absorbed by the magma from the overlying sediments. Brown amphibole was not observed in lower specimens.

The plag. and mica are nonmagnetic impurities. The anat. probably formed cogenetically with maghemo-magnetite during diagenetic oxidation of titanomagn.

Light turquoise mineral on periphery of large $(10 \times 23 \mathrm{~mm})$ ovoid expansion on vein; ovoid is filled largely by calc., with lesser celad.; the peripheral celad. apparently forms books with their cleavages perpendicular to the surface of the ovoid.

Irregular, ovoidal patch, about $1 \mathrm{~cm}$ in maximum dimension; mainly an irregular mixture of earthy brown and resinous deep green material; also minor vitreous, deep red brown patches which may be oxidized pyrite (or another opaque mineral); the formation of the whole patch may in fact have been controlled by the local environment created by the oxidation of pyrite. Earthy brown material emphasized in X-rayed sample.
MONT., PLAG.; Minor Mica; trace K-fld.?

PLAG., MICA.; Minor Mont.; trace amph., apat.

PLAG., MICA., AMPH.; Minor Mont., Apat. For plag., $\Delta 2 \theta=1.85^{\circ} ; \Gamma=+0.69^{\circ}$

Composition more sodic than $\mathrm{An}_{63}$

PLAG., CELAD.; Minor K-fld., Cpx., trace mont.?

PLAG., CELAD.; Minor, K-fld.; trace ampl. cpx., calc.

MAGHEMO-MAGN. $\left(\mathrm{a}_{\mathrm{O}}=8.381 \AA\right)$; Minor Anat., Plag.; trace mica, ilm.?

CELAD.; Minor Calc.

GOET., CELAD.

Core shows greenish gray basalt above, sharply bounded against brownish gray basalt below, as if a celad. or $\mathrm{K}_{2} \mathrm{O}$ diffusion or metasomatic "front" were advancing from above (see discussion in text). Veins in the greenish gray basalt are celad. with scattered patches of calc.; at the "front" the veins are mixed (calc. with celad. selvages), and they change to calc. as they cross the front into gray basalt. Readily visible patches of calc. are present in the gray basalt, but not in the greenish gray. Tiny specks of calc. (visible by effervescence in cold $1 \mathrm{~N} \mathrm{HCl}$ ) occur in both rock types, but apparently more abundantly in the gray basalt.

Vein in greenish Center is medium blue green, outer zones are dark CELAD.; trace mont. gray basalt green. The celad. is dioctahedral $\left(\mathrm{d}_{(060)}=1.513 \AA\right)$

Gray basalt

Total rock. The grain size and the presence of chl. suggest the interior of a flow or sill where deuteric reactions occurred. The mont. is trioctahedral $\left(\mathrm{d}_{(060)}=1.535 \AA\right)$ and dominantly but not wholly $\mathrm{Na}$-saturated.
PLAG., MONT., CPX.; Minor K-fld., Ilm.; trace mica (celad.), chl. 


\begin{tabular}{|c|c|c|c|}
\hline Specimen & Rock Type & Comments & Mineralogy (X-Ray) \\
\hline \multicolumn{4}{|c|}{ Site 170 - Continued } \\
\hline $16-1,24-37 \mathrm{~cm}$ & $\begin{array}{l}\text { Magnetic heavy } \\
\text { minerals from } \\
\text { brownish gray } \\
\text { basalt, a few cm } \\
\text { below "front" }\end{array}$ & $\begin{array}{l}\text { Much impurity. The Mt is almost pure to judge } \\
\text { from the unit cell edge; it probably formed, along } \\
\text { with anat., during diagenetic oxidation of primary } \\
\text { titanomagn.; it suggests that titanomagn. does not } \\
\text { alter directly to a stable maghemite-magnetite } \\
\text { solid solution, but goes through intermediate } \\
\text { states. It also indicates that an oxidation "front" } \\
\text { has moved ahead of whatever metasomatic } \\
\text { "front" controlled the contact of greenish gray } \\
\text { versus brownish gray basalt (see discussion in } \\
\text { text). }\end{array}$ & $\begin{array}{l}\text { MAGN. }\left(\mathrm{a}_{\mathrm{o}}=8.393 \AA\right), \text { PLAG.; Minor } \\
\text { Anat., Ilm.; trace mont., mica, K-fld., chl. }\end{array}$ \\
\hline $16-1,71-77 \mathrm{~cm}$ & Gray basalt & $\begin{array}{l}\text { Total rock; dark grayish brown, irregular, equant } \\
\text { patches of mont. are present (similar patches are } \\
\text { more abundant in } 16-2,0-14 \mathrm{~cm} \text {; see below); the } \\
\text { patches, which may contain fresh or tarnished } \\
\text { pyrite grains, likely to be altered late interstitial } \\
\text { residuum and perhaps in part altered pyroxene. } \\
\text { Both } \mathrm{Na-saturated} \mathrm{and} \mathrm{non-Na-saturated} \mathrm{types} \\
\text { of mont are present, with the non-Na-saturated } \\
\text { mont. dominating. }\end{array}$ & $\begin{array}{l}\text { MONT., PLAG.; Minor Cpx.; trace ilm., } \\
\text { K-fld., chl., mica? }\end{array}$ \\
\hline $16-1,115-119 \mathrm{~cm}$ & Basalt & $\begin{array}{l}\text { Total rock. The mont. is non-Na-saturated, with } \\
\text { only a faint suggestion of Na-saturated mont. }\end{array}$ & $\begin{array}{l}\text { PLAG., MONT.; Minor Cpx., K-fld.; trace } \\
\text { chl., ilm., mica. (and mixed-layer } \\
\text { chl.-mont.?) }\end{array}$ \\
\hline \multirow[t]{4}{*}{$16-2,0-14 \mathrm{~cm}$} & $\begin{array}{l}\text { Intersertal } \\
\text { mont. }\end{array}$ & $\begin{array}{l}\text { Dark greenish grayish brown ("olive brown"), } \\
\text { intersertal patches; mainly irregular in shape. The } \\
\text { larger ones are ovoid, like amygdules (altered } \\
\text { chlorophaeite?). The Amph. is probably a relict } \\
\text { deuteric alteration product of an interstitial } \\
\text { residuum of the magma; it is probably low-Al } \\
\text { hornblende or actinolite, but an X-ray peak near } \\
29^{\circ} 2 \theta \text { suggests a cummingtonitic amph. The } \\
\text { mont. is trioctahedral (d }(060)=1.54 \AA \text { ) and } \\
\text { Na-saturated. In places the intersertal patches } \\
\text { contain variole-like arrays of tiny prisms; they are } \\
\text { probably subradial clusters of deuteric amph. } \\
\text { needles (see text; compare } 16-2,135-150 \mathrm{~cm} \\
\text { below). }\end{array}$ & MONT.; trace amph. \\
\hline & $\begin{array}{l}\text { Largest mont. } \\
\text { patch seen }\end{array}$ & $\begin{array}{l}\text { Dark greenish grayish brown, like the intersertal } \\
\text { mont. (see above), but forms the largest patch in } \\
\text { the specimen (irregular shape, } 5 \times 3 \mathrm{~mm} \text { ). The } \\
\text { mont. is trioctahedral }(\mathrm{d}(060)=1.54 \AA \text { ) and Na- } \\
\text { saturated. The patch contains thin dark "prisms" } \\
\text { some of them in subradial, variole-like arrays, } \\
\text { others randomly scattered; they are probably } \\
\text { deuteric amphibole as in the intersertal mont. (see } \\
\text { above); also compare } 16-2-135-150 \mathrm{~cm} \text { below). The } \\
\text { patch also contains opaque hexagonal plates (see } \\
\text { below). }\end{array}$ & MONT.; Minor Plag.; trace amph., ilm. \\
\hline & $\begin{array}{l}\text { Opaque hexa- } \\
\text { gonal plate }\end{array}$ & $\begin{array}{l}\text { Euhedral, with growth steps; dark brown streak. } \\
\text { Separated from the largest mont. patch seen (see } \\
\text { above) and X-rayed in a powder camera. }\end{array}$ & ILM. \\
\hline & Yellow sulfide & $\begin{array}{l}\text { Concentration of grains pried out with a needle; } \\
\text { much host rock contamination. Grains occur both } \\
\text { in intersertal mont. and among groundmass plag. } \\
\text { and cpx.; may form polygranular clusters of } \\
\text { euhedral cubes. One tiny white calc.(?) patch (the } \\
\text { only one seen) was also pried out and included in } \\
\text { the sample. The mont. is Na-saturated as in the } \\
\text { intersertal areas (see above). }\end{array}$ & $\begin{array}{l}\text { PYRITE, MONT.; Minor Plag.; trace mica, } \\
\text { amph., chl., K-fld., calc. }\end{array}$ \\
\hline $16-2,61-70 \mathrm{~cm}$ & Basalt & Total rock. The mont. is non-Na-saturated. & $\begin{array}{l}\text { MONT., PLAG., K-FLD.; Minor Cpx., Mica, } \\
\text { Mt.?; trace ilm., chl. }\end{array}$ \\
\hline
\end{tabular}


APPENDIX A - Continued

\begin{tabular}{|c|c|c|}
\hline Specimen & Rock Type & Comments \\
\hline \multicolumn{3}{|c|}{ Site 170 - Continued } \\
\hline \multirow[t]{3}{*}{$16-2,135-150 \mathrm{~cm}$} & Basalt & $\begin{array}{l}\text { Total rock. The mont. is non-Na-saturated, with only } \\
\text { a faint suggestion of Na-saturated material. }\end{array}$ \\
\hline & $\begin{array}{l}\text { Intersertal mont. } \\
\text { with amphibole } \\
\text { inclusions }\end{array}$ & $\begin{array}{l}\text { Deep gray-brown intersertal patches with faint } \\
\text { greenish tinge; they enclose fibrous, bronzy brown } \\
\text { bundles with a silky luster. Most host rock con- } \\
\text { tamination was removed by hand picking, but } \\
\text { evidently not all plag. was eliminated. No chl. } \\
\text { detected. The amph. is probably low-Al hornblende } \\
\text { or actinolite, but an X-ray peak near } 29^{\circ} 2 \theta \text { indi- } \\
\text { cates a cummingtonitic amph. The mont. is } \\
\text { Na-saturated. }\end{array}$ \\
\hline & $\begin{array}{l}\text { Magnetic heavy } \\
\text { materials }\end{array}$ & $\begin{array}{l}\text { No anat. detected. The titano-magn. is Us } 19 \text { if it } \\
\text { lies on the Us-Mt join. The primary igneous assem- } \\
\text { blage appears to be titanomagnetite-ilmenite, and } \\
\text { indicates moderately oxidizing conditions in the } \\
\text { magma. The diagenetic assemblage maghemo- } \\
\text { magnetite plus anat. and the mixed diagenetic- } \\
\text { primary assemblage magnetite-anatase-ilmenite, } \\
\text { which occur barely } 1.5 \text { m higher, are absent in this } \\
\text { specimen and confirm that a fairly sharp oxidation } \\
\text { "front" has moved somewhat ahead of whatever } \\
\text { metasomatic "front" controlled the sharp contact } \\
\text { in } 16-1,24-37 \mathrm{~cm} \text { (see above). }\end{array}$ \\
\hline
\end{tabular}

Site 171

26-CC Basalt

Total rock; dark green when powdered; the wetted sample, on drying in air, is extremely cracked due to shrinkage. The mont. varies from Na-saturated to non-Na-saturated; it expands slowly on gly colation. No pyroxene peaks; pyroxene is essentially wholly replaced by mont.

Density and magnetic fractions:

Magnetic material Essentially all titanomagn. remains in composite of all densities, but mostly less dense than $\mathrm{MeI}_{2}$ grains after grinding because of the fine grain size of the rock, and comes out in the fraction which floats in $\mathrm{MeI}_{2}$. No ilm. or anat. detected, so the original opaque assemblage appears to have been solely a moderately titaniferous titanomagn. (see below). The present titanomagn. is $\mathrm{Us}_{22}$ if it is on the Us-Mt join.

Nonmagnetic, Mainly opaque, metallic blue black; minor plag. denser than $\mathrm{MeI}_{2}$ The presence of anat. suggests that the original titanomagn. was even richer in Us than the present titanomagn. (see above). The spinel is probably picotite, or possibly magnesiochromite; its broad $\mathrm{X}$-ray peaks indicate that it has a significant range of composition, with uncertain suggestions of two modes, a larger one at $\mathrm{a}_{\mathrm{O}}=8.251 \AA$, a smaller one at $\mathrm{a}_{\mathrm{O}}=8.288 \AA$.

Nonmagnetic, less dense than bromoform

$27-1,39-45 \mathrm{~cm}$

Orange brown selvages of zoned veins

$27-1,65-70 \mathrm{~cm}$
Basalt
Zoned veins composed of calc. in centers and phil. selvages. These cut altered glass and the adjacent by seawater alteration prior to burial or during early diagenesis, immediately following burial.

Total rock
MONT., PLAG., ILM.; trace mica, cpx., chl. MONT.; trace amph., plag.

TITANOMAGN. $\left(\mathrm{a}_{\mathrm{O}}=8.408 \AA\right)$, PLAG., CPX.; Minor Mont., Ilm.; trace K-fld.?

MONT., PLAG.; trace ilm.

TITANOMAGN. $\left(\mathrm{a}_{\mathrm{O}}=8.412 \AA\right)$; Minor Plag.

SPINEL $\left(\mathrm{a}_{\mathrm{O}}=8.273 \AA\right)$, PLAG.; Minor Anat.

PLAG.

$\Delta 2 \theta=2.00^{\circ} ; \Gamma=+0.94^{\circ}$

Composition in the range An53-74 spherulite layer of the host basalt; probably formed
PHIL., CALC.

MONT., PLAG.; Minor Cpx., Mt.; trace ilm. 


\begin{tabular}{lll}
\hline Specimen & Rock Type & Comments \\
\hline
\end{tabular}

Site 171 - Continued

$27-1,127-133 \mathrm{~cm}$

Green, massive clasts in detrital limestone
$27-1,133-142 \mathrm{~cm}$

$27-1,133-142 \mathrm{~cm}$
Light gray altered glass from layer (b) (see text)

Medium gray altered glass from layer (f) (see text)
Several light and medium green clasts from a sandy detrital limestone which fills an interpillow void clasts are angular to subangular, massive, homogeneous, soft, dense, microcrystalline, waxy, no recognizable igneous texture; probably altered glass, $\mathrm{X}$-rayed sample contaminated by sandy matrix. Plag. is not visible in the clasts and may be contamination from the matrix; Celad. probably occurs mainly in the darker green clasts (compare clasts from breccia 17-167-95-2, 127-128 cm). Slight expansion of the celadonite lattice (shift of X-ray peaks) on exposure to ethylene glycol vapor suggests that minor mont. is randomly interlayered in the celad. The mont. is Na-saturated.

Translucent, light gray, soft, resinous, altered glass from a layer of altered glass in the selvage of a pillow (layer (b) in text); most of the altered glass in this layer is darker gray than the X-rayed sample. The plag. detected may occur in spherulites or as microphenocrysts.

Noncalcitized altered glass (layer (f) in text) immediately below the contact of the pillow with a sandy detrital limestone which fills an interpillow void. The altered glass is massive, resinous, mainly medium gray. The plag. may occur in spherulites. The poor crystallinity of the mont may be typical of that in altered basaltic glass (compare 166-29-2, $16-25 \mathrm{~cm}$ and $169-12-2,115-117 \mathrm{~cm}$ ).
CELAD., MONT., CALC., PLAG.; Minor Mont. interlayered with the celad.; trace anat.

PLAG.; Minor Calc.; trace mont., mixedlayer mica-mont.

PLAG., MONT. (poorly crystallized); trace calc.

Various components within (c): an 8-to-10rnm thick layer of light gray to light brownish gray, highly calcitized, altered glass with prominent dark spots; near but not quite at the contact of the pillow with the sandy detrital limestone filling the interpillow void:

Upper light gray part of the layer

Middle light grayish buff or brownish gray part of the layer

Black

"amygdules"

Red brown glassy grains
The mont. detected may occur in the altered glass, or possibly in black "amygdules" which slightly contaminate the X-rayed sample (see below). The plag. probably occurs as microphenocrysts, but possibly also in spherulites. The d-value of the (001) peak of the mixed-layer mica-mont. indicates that mica is more abundant than mont.

The d-value of the (001) peak of the mixed-layer mica-mont. indicates that mica is more abundant than mont.

Black, irregular ovoids, soft, resinous, appear to be amygdules; the calc. and plag. are contamination from the surrounding altered glass. The chl. is unlikely to be deuteric may indicate mild postmagmatic hydrothermal metamorphism.

Two red brown, Fe-stained, transparent, glassy, moderately hard, brittle patches. One patch is at the contact of layer (c) with medium gray noncalcitized, altered glass (layer (f); see text). Much contamination in the X-rayed sample from the surrounding altered glass. The d-value of the (001) peak of the mixed-layer mica-mont. indicates that mica is more abundant than mont.

$27-1,133-142 \mathrm{~cm}$
Deep green patch, with greenish yellow center, from the basalt below the altered glass selvage
CALC., PLAG.; Minor mixed-layer micamont.; trace mont.

CALC., PLAG.; trace mixed-layer micamont.

MONT., CALC.; Minor Plag.; trace chl.

PHIL., PLAG., mixed-layer MICA-MONT.; trace calc.

CELAD.; trace mont. 


\begin{tabular}{llcl}
\hline Specimen & Rock Type & Comments & Mineralogy (X-Ray) \\
\hline
\end{tabular}

Site 171 - Continued

$27-2,17-26 \mathrm{~cm} \quad$ Basalt

Dark green rims of mont. ovoids

$27-2,75-86 \mathrm{~cm}$

Mont., mainly
from ovoidal
patches

$27-3,19-27 \mathrm{~cm}$

$27-3,27-37 \mathrm{~cm}$
Calc.

Calc.

Zoned ovoids with dark green rims

Dark green ovoids and rims of zoned ovoids

Green outer selvage of calc. vein
Total rock. The mont. is non-Na-saturated, with only PLAG., CPX., MONT.; trace ilm. a faint suggestion of a $\mathrm{Na}$-saturated type.

Dark green, resinous rims; much contamination from MONT., PLAG. the mont. cores of the ovoids and from the host rock (the plag. in the sample is probably from the host rock). The mont. is Na-saturated.

Total rock. The mont. is mainly non-Na-saturated, with only a faint suggestion of a Na-saturated type.

This is the mont. separated from the rocks at Site 171 for chemical analysis, prior to final purification. It is well crystallized and trioctahedral $\left(\mathrm{d}_{(060)}\right)$ $1.5335 \AA$ ). Most of it is from this specimen, and most of that from the abundant, fairly large, brownish gray, flaky amygdules(?) with dense, dark green, resinous rims. The dark green mont. came out in impure dense fractions during purification and was eliminated. A minor amount of the mont. came from relatively large, brownish gray amygdules(?) composed of intimately mixed calcite and mont.; calc. impurity in the analyzed mont. is mainly from these amygdules(?). X-ray monitoring of many density fractions during final purification of the mont. indicates that all pyrite and pyroxene were eliminated, whereas minor plag. and a trace of calc. remain. The impure dense fractions of mont., which were eliminated, are non-Na-saturated, whereas the lighter fractions accepted for analysis are $\mathrm{Na}-$ saturated or a mixture of both. In view of the mont. in the total rock (see above), these results suggest that the mont. which replaces pyroxene and late magmatic residua is mainly non-Na-saturated, whereas that in amygdules(?), which was probably deposited from and more strongly influenced by connate pore waters, tends to be Na-saturated.

Separated during purification of the mont. fo chemical analysis (see above); mainly from amygdules(?) composed of intimately mixed calc. and mont.

Colorless to white, from the centers of large white calc. patches without admixed mont. This clean calc. is distinctly lower in $\mathrm{MgCO}_{3}$ than that which is intimately mixed with mont. (see above), indicating local microenvironmental control during deposition of coexisting calc. and mont. from solution. Alternatively, changes of solution chemistry at different paragenetic stages may be involved, such that early calc. is Mg-poorer, and late calc., mixed with mont., is Mg-richer.

Small, dense, gray brown, slightly greenish, irregular ovoids with dark green, resinous rims; occur only along one side of the bottom of the specimen. The mont. is well crystallized and composed of distinct Na-saturated and non-Na-saturated types.

Concentration of dark green, irregular ovoids and patches, and dark green rims of zoned ovoids and patches; much contamination from host basalt and from mont. cores of zoned ovoids. Mont. is wellcrystallized and Na-saturated.

Dull, deep green, slightly brownish selvage of calc. vein. The mont. is a mixture of Na-saturated and non-Na-saturated types with a dominance of the non-Na-saturated type.
PLAG., MONT.; Minor Cpx.; trace ilm.

MONT.; Minor Plag., Calc.; trace pyrite For the plag.: $\Delta 2 \theta=1.99^{\circ} ; \Gamma=+0.93^{\circ}$ Composition in the range $\mathrm{An}_{52-73}$

CALC. (4.0 mole $\% \mathrm{MgCO}_{3}$ )

CALC. (2.5 mole $\% \mathrm{MgCO}_{3}$ )

MONT.

MONT., PLAG.; trace mica, calc.

MONT.; Minor Calc. 


\begin{tabular}{|c|c|c|c|}
\hline Specimen & Rock Type & Comments & Mineralogy (X-Ray) \\
\hline \multicolumn{4}{|c|}{ Site 171 - Continued } \\
\hline \multirow[t]{6}{*}{$27-3,80-92 \mathrm{~cm}$} & Basalt & $\begin{array}{l}\text { Total rock. The mont. is a mixture of Na-saturated } \\
\text { types, with a dominance of the non-Na-saturated } \\
\text { type. }\end{array}$ & PLAG., CPX., MONT.; Minor Ilm. \\
\hline & Pyrite & $\begin{array}{l}\text { Spherule with radial internal structure and faceted } \\
\text { exterior; occurs in an irregular, elongate ovoid of } \\
\text { mont. Other pyrite grains and clusters in the rock } \\
\text { lack the radial structure. }\end{array}$ & PYRITE \\
\hline & \multicolumn{3}{|c|}{ Density and magnetic fractions: } \\
\hline & $\begin{array}{l}\text { Magnetic, all } \\
\text { densities }\end{array}$ & $\begin{array}{l}\text { Much Mt. remained in composite grains which } \\
\text { floated in } \mathrm{MeI}_{2} \text { because of the fine grain size of the } \\
\text { rock; the unit cell edge indicates nearly pure Mt., } \\
\text { from which it appears that the primary assemblage } \\
\text { was probably ilm plus either Ti-poor titanomagn. } \\
\text { or pure Mt. }\end{array}$ & $\begin{array}{l}\text { MT }\left(\mathrm{a}_{\mathrm{O}}=8.393 \AA\right) \text {; Minor Plag., Cpx.; } \\
\text { trace ilm., mont. }\end{array}$ \\
\hline & $\begin{array}{l}\text { Nonmagnetic, } \\
\text { denser than } \mathrm{MeI}_{2}\end{array}$ & $\begin{array}{l}\text { Opaque metallic grains plus a transparent impurity. } \\
\text { The spinel is probably picotite, or possibly mag- } \\
\text { nesiochromite; it is very well crystallized and } \\
\text { apparently quite resistant to seawater alteration } \\
\text { and diagenesis. }\end{array}$ & SPINEL $\left(\mathrm{a}_{\mathrm{o}}=8.253 \AA\right)$; Minor Plag. \\
\hline & $\begin{array}{l}\text { Nonmagnetic, less } \\
\text { dense than } \mathrm{MeI}_{2}\end{array}$ & & $\begin{array}{l}\text { PLAG.; Minor Cpx.; trace mont. } \\
\Delta 2 \theta=1.96^{\circ} ; \Gamma=+0.87^{\circ} \\
\text { Composition is in the range An } 44-70\end{array}$ \\
\hline \multirow[t]{5}{*}{$27-3,104-110 \mathrm{~cm}$} & \multicolumn{3}{|c|}{$\begin{array}{l}\text { Zoned lower edge of pillow underlain by sandy detrital limestone which contains a large (at least } 65 \times 17 \times 8 \mathrm{~mm} \text { ) } \\
\text { subangular clast of basalt and thus may grade to breccia: }\end{array}$} \\
\hline & $\begin{array}{l}\text { Calc. layer at } \\
\text { bottom of pillow }\end{array}$ & $\begin{array}{l}2 \text { to } 3 \mathrm{~mm} \text { thick; light tan, soft, fractured, highly } \\
\text { calc.; of type which, at the top edge of the pillow } \\
\text { contains calc. and mixed-layer mica-mont. If this } \\
\text { layer is altered glass, it is the outermost layer of } \\
\text { the pillow and is extremely calcitized. }\end{array}$ & $\begin{array}{l}\left.\text { CALC. ( } 3.5 \text { mole } \% \mathrm{MgCO}_{3}\right) \text {; trace mont., } \\
\text { anat.? }\end{array}$ \\
\hline & $\begin{array}{l}\text { Same as above, } \\
\text { denser than } \\
\text { bromoform }\end{array}$ & $\begin{array}{l}\text { Light tan layer, finely ground, centrifuged in } \\
\text { bromoform to concentrate anat.(?) }\end{array}$ & CALC.; (trace spinel of some sort? Unlikely \\
\hline & $\begin{array}{l}\text { Black clast in } \\
\text { detrital limestone }\end{array}$ & $\begin{array}{l}\text { Largest black clast }(5 \times 2.5 \mathrm{~mm}) \text { in the detrital } \\
\text { limestone below the pillow, and one of the largest } \\
\text { clasts of any type. It is soft, brittle, conchoidal, } \\
\text { coal-like; it has a dark red brown streak. The outer } \\
\text { edge was brecciated and cemented by light gray } \\
\text { calc. The goet. is well-cry stallized. }\end{array}$ & GOET.; trace chab., chl.(?), calc. \\
\hline & Sparry calc. & $\begin{array}{l}\text { Coarse-grained patch between the pillow and the } \\
\text { large, subangular basalt clast in the detrital } \\
\text { limestone. }\end{array}$ & CALC. ( 3.5 mole $\% \mathrm{MgCO}_{3}$ ) \\
\hline \multirow[t]{5}{*}{$33-\mathrm{CC}$} & Basalt & $\begin{array}{l}\text { Total rock. Relict red brown "iddingsite" occurs in } \\
\text { mont. pseudomorphs after olivine. The rock is so } \\
\text { chilled (fine-grained) that the chl. is probably a } \\
\text { product of low-grade, post-magmatic hydrothermal } \\
\text { metamorphism. }\end{array}$ & PLAG., CPX.; minor Mont., Ilm., Chl. \\
\hline & Calc. vein & $\begin{array}{l}\text { Cross-fiber structure, silky luster, brown discolora- } \\
\text { tion. The mont. may be wholly or in part a con- } \\
\text { taminant from the host rock. }\end{array}$ & CALC. (3.0 mole $\% \mathrm{MgCO}_{3}$ ); trace mont. \\
\hline & $\begin{array}{l}\text { Reddish brown } \\
\text { vein }\end{array}$ & $\begin{array}{l}\text { Soft, sectile, flesh-toned light reddish brown material } \\
\text { which forms short segments of veins and the sel- } \\
\text { vages of some calcite-filled segments of the same } \\
\text { veins. The mont. is Na-saturated. }\end{array}$ & MONT.; Minor Calc.; trace chl.? \\
\hline & \multicolumn{3}{|c|}{ Density and magnetic fractions: } \\
\hline & $\begin{array}{l}\text { Nonmagnetic, } \\
\text { denser than } \mathrm{MeI}_{2}\end{array}$ & Opaque metallic grains and light brown grains & ILM.; minor Cpx.; trace plag. \\
\hline
\end{tabular}


APPENDIX A - Continued

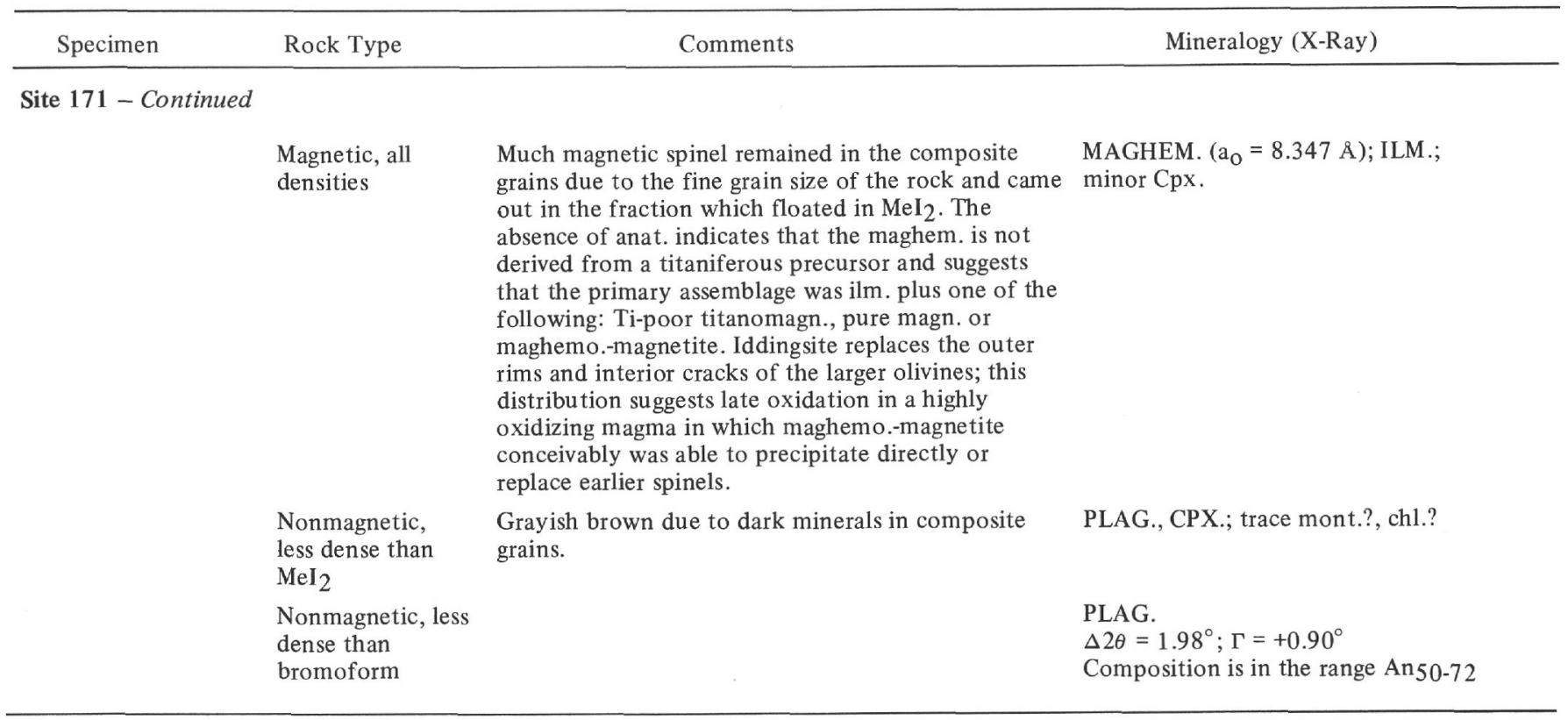

\section{APPENDIX B}

\section{LITHOLOGIC DESCRIPTIONS}

\section{SITE 164}

The sedimentary section of pelagic brown clay had volcanic contributions, as evidenced by its zeolite, palagonite, and glass content, and as suggested by the montmorillonitic clay. Brown clays are discussed elsewhere in these Initial Reports and are not elaborated here.

Basement sampled at Site 164 is a series of flows and pillows of porphyritic ocean ridge basalt (Table 1; Figures 1, 2, and 3). Texturally, the specimens range from glass to fine-grained variolitic basalt. Phenocrysts and microphenocrysts are dominantly plagioclase; some are olivine (now totally altered). At least three stages of crystalization are evident. Some, but not all, of the earliest plagioclase is skeletal and may be xenocrysts which reacted with the magma; alternatively, it may simply have grown with a skeletal habit. There is little if any olivine in the groundmass, which is spherulitic to variolitic, rarely microgranular, and crystallized rapidly.

These basalts have been moderately altered. Early phillipsite veins cut altered glass selvages, but later diagenetic alteration is nonzeolitic. Cores or intermediate zones of early plagioclase are replaced by monoclinic K-feldspar, montmorillonite, and minor amounts of calcite (Plate 1, Figures 1 and 2). The abundance of $\mathrm{K}$-feldspar decreases downward and suggests a supply of $\mathrm{K}$ from above. Olivine is replaced by montmorillonite and minor calcite, as well as by $\mathrm{Fe}$ oxide (Plate 1, Figures 3,4 and 5). Glass and some pyroxene are now replaced by montmorillonite, but most pyroxene survives. Veins and amygdules are filled by montmorillonite, calcite, celadonite, and minor $\mathrm{Fe}$ oxide. Commonly the amygdules are zoned. Alteration is not extreme, perhaps due to lack of carbonate sediments, and thereby a low $\mathrm{CO}_{2}$ activity, as well as to the fine grain size which has influenced the size, abundance, and nature of crystalline and glassy residual phases. In this respect, compare the alteration at Site 166 .

\section{Petrography}

17-164-27-1, $102 \mathrm{~cm}$ : Specimen consists of medium to light gray porphyritic basalt with a light brown chilled selvage. No pyroxene phenocrysts are present, and only one distince pyroxene grain (equant $0.016 \mathrm{~mm})$ was seen in the groundmass. Rare, thin $(0.002$ $\mathrm{mm}$ ) calcite and celadonite veins are present.

\begin{tabular}{|c|c|c|}
\hline $\begin{array}{c}\text { Component } \\
(\mathrm{min} / \mathrm{max} \text { size }-\mathrm{mm})\end{array}$ & $\begin{array}{l}\text { Average } \\
\text { Size }(\mathrm{mm})\end{array}$ & $\begin{array}{c}\text { Volume } \\
(\%)\end{array}$ \\
\hline $\begin{array}{l}\text { Plagioclase phenocrysts } \\
(0.3 \times 0.09 / 1.5 \times 0.35)\end{array}$ & $0.45 \times 0.36$ & 3.9 \\
\hline $\begin{array}{l}\text { Plagioclase microphenocrysts } \\
(0.1 \times 0.01 / 0.4 \times 0.025)\end{array}$ & $0.25 \times 0.03$ & 2.7 \\
\hline $\begin{array}{l}\text { Olivine microphenocrysts } \\
\quad \text { (Pseudomorphs) } \\
(0.17 \times 0.12 / 0.38 \times 0.35)\end{array}$ & $0.25 \times 0.17$ & 1.6 \\
\hline $\begin{array}{l}\text { Groundmass (including small opaque } \\
\text { grains) }\end{array}$ & & 87.4 \\
\hline $\begin{array}{l}\text { Larger opaque grains } \\
(0.006)\end{array}$ & & 2.8 \\
\hline $\begin{array}{l}\text { Montmorillonite }+ \text { celadonite } \\
\text { amygdules } \\
(0.003 / 0.63 \times 0.55)\end{array}$ & & 1.4 \\
\hline $\begin{array}{l}\text { Calcite amydules, minor celadonite } \\
(0.27 / 0.8 \times 0.55)\end{array}$ & & 0.2 \\
\hline
\end{tabular}

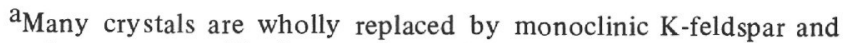
minor montmorillonite except for thin $(0.003$ to $0.004 \mathrm{~mm})$ sodic rims. 
17-164-27-1, $124 \mathrm{~cm}$ : This sample is like 17-164-27-1, $102 \mathrm{~cm}$ but with more plagioclase phenocrysts (estimated 15 to $20 \%$ ) and a coarser grained groundmass. It is probably from the interior of the same flow or pillow as 17-164-27-1, $102 \mathrm{~cm}$.

17-164-28-1, $87 \mathrm{~cm}$ : Specimen consists of chilled, slightly brownish gray basalt. Calcite veins (excluded from the mode) of irregular trend are present; they are zoned by inclusions of Fe oxide (and montmorillonite?). In one vein there are concentrations locally of long, vermicular, cross-fiber "books" of green montmorillonite.

\begin{tabular}{|c|c|c|}
\hline $\begin{array}{c}\text { Component } \\
(\mathrm{min} / \mathrm{max} \text { size }-\mathrm{mm})\end{array}$ & $\begin{array}{l}\text { Average } \\
\text { Size }(\mathrm{mm})\end{array}$ & $\begin{array}{l}\text { Volume } \\
(\%)\end{array}$ \\
\hline $\begin{array}{l}\text { Plagioclase phenocrysts, including } \\
\text { montmorillonite alteration }{ }^{\mathrm{a}} \\
(0.3 \times 0.17 / 5 \times 2)\end{array}$ & $0.9 \times 0.5$ & 5.9 \\
\hline $\begin{array}{l}\text { Plagioclase microphenocrysts } \\
(0.1 \times 0.01 / 0.9 \times 0.1)\end{array}$ & $0.4 \times 0.05$ & 21.6 \\
\hline $\begin{array}{l}\text { K-feldspar replacing plagioclase } \\
\text { phenocrysts and microphenocrysts }\end{array}$ & & 1.7 \\
\hline $\begin{array}{l}\text { Olivine (pseudomorphs), phenocrysts } \\
\text { and microphenocrysts } \\
(0.1 \times 0.07 / 2.2 \times 1.1)\end{array}$ & $0.5 \times 0.3$ & 3.4 \\
\hline Groundmass plagioclase & & 2.9 \\
\hline $\begin{array}{l}\text { Groundmass pyroxene, rarely } \\
\text { microphenocrystic } \\
\text { skeletal }(0.3) \\
\text { equant, solid }(0.05)\end{array}$ & & 38.7 \\
\hline $\begin{array}{l}\text { Opaque grains } \\
\text { equant }(0.012 / 0.02) \\
\text { elongate }(0.06 \times 0.004)\end{array}$ & & \\
\hline Groundmass montmorillonite & & 15.4 \\
\hline $\begin{array}{l}\text { Montmorillonite amygdules } \\
(0.6)\end{array}$ & & 0.7 \\
\hline Calcite amygdules ${ }^{\mathrm{b}}$ & & 0.5 \\
\hline Calcite replacing plagioclase & & 0.2 \\
\hline
\end{tabular}

\footnotetext{
${ }^{\mathrm{a}}$ The cores are variably replaced by monoclinic K-feldspar (component 3 ) and brown montmorillonite (Plate 1, Figure 1).

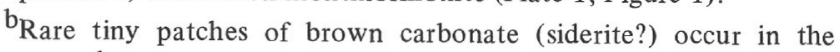
groundmass.
}

17-164-28-2, $116 \mathrm{~cm}(\mathrm{~b})$ : Specimen consists of plagioclase-olivine porphyritic basalt, similar to the overlying rocks. Alteration is of the same types as in the overlying rocks, but is less extreme and does not include $\mathrm{K}$-feldspar.

Early olivine is completely altered (Plate 1, Figure 3). Early plagioclase may be selectively altered along a zone just inside the rim, or along twin planes, to gray green montmorillonite, calcite or both (Plate 1, Figure 2). The altered glass of specimen 28-2, 116 $\mathrm{cm}$ (a) is vertically laminated and indicates the side of a pillow.

17-164-28-6, $137 \mathrm{~cm}$ : Specimen is dark gray variolitic basalt porphyry. The groundmass is relatively coarse-grained. This and the paucity of vesicles suggest that this specimen is from the interior of a flow or pillow, well below the chilled crust. Irregular joints are filled or lined by dark Fe oxide, green brown montmorillonite(?), celadonite or calcite; the fillings may be zoned or may grade from one type to another along a given joint.

\begin{tabular}{llc}
\hline \multicolumn{1}{c}{$\begin{array}{c}\text { Component } \\
(\mathrm{min} / \mathrm{max} \text { size }-\mathrm{mm})\end{array}$} & $\begin{array}{c}\text { Average } \\
\text { Size }(\mathrm{mm})\end{array}$ & $\begin{array}{c}\text { Volume } \\
(\%)\end{array}$ \\
\hline $\begin{array}{l}\text { Plagioclase phenocrysts, including } \\
\text { montmorillonite alteration }\end{array}$ & $0.55 \times 0.23$ & 6.7 \\
$\begin{array}{l}(0.19 \times 0.15 / 1.4 \times 0.48) \\
\text { Plagioclase microphenocrysts } \\
(0.07 \times 0.004 / 0.95 \times 0.05)\end{array}$ & $0.3 \times 0.013$ & 21.1 \\
$\begin{array}{l}\text { Olivine (pseudomorphs), mainly } \\
\text { phenocrysts and microphenocrysts, }\end{array}$ & $0.4 \times 0.35$ & 2.4 \\
$\quad$ some groundmass \\
$\begin{array}{l}\text { (0.05 } \times 0.03 / 1.4 \times 0.55) \\
\text { K-feldspar replacing plagioclase } \\
\text { phenocrysts }\end{array}$ & & \\
$\begin{array}{l}\text { Groundmass pyroxene and montmoril- } \\
\text { lonite, plus minor plagioclase }\end{array}$ & & \\
$\begin{array}{l}\text { Groundmass plagioclase } \\
\text { Opaque grains in groundmass } \\
\text { equant }(0.004 / 0.013) \\
\text { elongate }(0.023 \times 0.005 /\end{array}$ & \\
$\quad 0.062 \times 0.013)$ & 60.3 \\
$\begin{array}{l}\text { Opaque grains in olivine pseudomorphs } \\
(0.06 \times 0.025 / 0.08 \times 0.07)\end{array}$ & \\
$\begin{array}{l}\text { Calcite in amygdules and in olivine } \\
\text { pseudomorphs }\end{array}$ & \\
$\begin{array}{l}\text { Montmorillonite amygdules } \\
(0.1 / 0.34 \times 0.30)\end{array}$ & \\
\hline
\end{tabular}

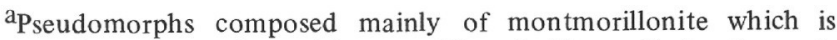
usually green or brownish green (Plate 1, Figure 4); locally, such as near veins, it is red or red brown due to oxidation. Green celadonite is minor.

$\mathrm{b}_{\text {The groundmass includes relatively coarse-grained parallel prisms }}$ of pyroxene which give a local "trachy toid" structure or texture (but not a flow structure as such). They resemble the interstitial components of spinifex-textured Precambrian ultramafic magmatic rocks and probably result from supercooling (see the discussion of $17-171-27-3,82-86 \mathrm{~cm}$ in which this texture is even better developed).

\section{SITE 165}

Hole $165 \mathrm{~A}$ yielded cores of volcanic-rich sediment and of flows with strong alkaline affinities. These rocks allow certain conclusions, and lead to additional speculations about the history of volcanism near the center of the Line Islands chain.

In the top 160 meters, volcanic contributions are only a small fraction of the total sediment. They are, however, conspicuous as the dark thin layers (one to a few $\mathrm{mm}$ thick) at the bases of individual calcareous turbidites that characterize the Middle Eocene to Lower Miocene, and especially the Upper Oligocene, section. Sand-sized grains include palagonite, glass, titanaugite, and feldspar. Apparently, the currents that transported eroded Eocene reef debris from the nearest emergent island to deep water also carried minor amounts of volcanic detritus from the submerged island slopes.

Cores 18 to 22 recovered a complex section of Campanian-aged turbidite beds that are dominantly of volcanic origin. These beds are the top of the archipelagic apron on the western side of the Line Islands. Their source, like that of the Maastrichtian and Eocene shallow-water carbonates in the overlying calcareous turbidites, probably was the guyot about $50 \mathrm{~km}$ east of Site 165 , or the vents on its slopes. These sediments, and the underlying interlayered flows and sediments, record the volcanic origin of this part of the Line Islands about 80 or 85 m.y. ago.

The sedimentary beds average about $20 \mathrm{~cm}$ thick and range over two orders of magnitude in thickness from less than $2 \mathrm{~cm}$ to more than 2 meters. In general, the thicker beds are coarser grained. Most beds are graded, but a host of other primary sedimentary structures, 
of types found in parts of exposed turbidite sections on land, are also present. These include cross-bedding and channeling in sandy and silty beds, parallel laminations in finer beds, penecontemporaneous convolutions and slumps, pebbly mudstones, and interstratification of turbidites with fine-grained pelagic sediment. Some of the fine laminations have been disturbed by burrowing.

These rocks range in texture from breccias and fine conglomerates to the more abundant sandstones and siltstones. Their colors are mainly dark greens and grays but are lighter where nannofossil components occur in the marly tops of beds. Individual sand grains and breccia clasts may be light to dark green, various shades of gray from nearly white to nearly black, light to dark brown, red brown, etc. Some of the larger fragments may be mottled or variegated in several of these colors.

The coarser components of all these beds are volcanic. Grains of basalt, glass, and palagonite are most common, but individual pyroxene, feldspar, and opaque oxide grains are present in many sandstone and siltstone beds. The glass and lithic grains show varying degrees of alteration. Most beds are friable, but some are bound firmly by clay, zeolites, celadonite, and calcite.

The primary sedimentary structures, grading, and mixture of compositions within individual beds show that these detrital sediments were eroded and transported from some other place. They are neither pyroclastites nor hyaloclastites deposited in place. Probably most of the sediment originally was fragmented volcanic material lying on unstable slopes at elevations higher than Site 165. Most fragments were chilled glass and pieces of flows and pillows, but the more vesicular pieces may have been in part pyroclastic. There is no clear-cut evidence of subaerial erosion of any grains. Part of the volcanic detritus is probably from the slopes of the guyot or other seamounts, but some beds, such as the 2.5 meter-thick breccia at about 340 meters depth, probably cae from a vent close to the site.

Below 420 meters, Hole 165 A penetrated a series of fine-grained, slightly porphyritic to aphyric flows or shallow intrusions of strongly alkaline affinities (Table 1; Figures 1,2 and 3), interlayered with sediments. $\mathrm{SiO}_{2}$ is low, alkalis are high, the alkali to $\mathrm{siO}_{2}$ ratio is high, total $\mathrm{Fe} /(\mathrm{Mg}+$ Total $\mathrm{Fe})$ exceeds 0.5 , and plagioclase is zoned from K-rich andesine (possibly some labradorite) to calcic anorthoclase (roughly Or33). These features indicate low-silica hawaiite rather than alkali basalt. The rocks crystallized under relatively oxidizing conditions, as indicated by relatively highly oxidized $\mathrm{Fe}$ and an oxide assemblage of ilmenite plus Ti-poor titanomagnetite. There is no evidence for significant oxidation during crystallization; so, the magma must have been erupted in a highly oxidized state, and this state probably characterized the chamber from which the magma was derived. The site is more than $50 \mathrm{~km}$ from the nearest seamount or guyot, without any evidence for a rift zone or other feeder from that guyot; so, these hawaiite magmas are probably derived directly from the mantle. Primary hornblende and biotite, and relatively coarse-grained pegmatoid patches rich in hornblende and calcite (Plate 1, Figure 6), indicate a volatile-rich magma which crystallized under high pressures thereby retaining the volatiles. With loss of volatiles, olivine would have crystallized instead of hornblende; as it is, relict olivine is notably scarce or absent. The volatiles included abundant $\mathrm{CO}_{2}$ which, in part, apparently segregated in an immiscible carbonatite magma from which silicate- and opaque-mineral-bearing calcite pods and veins were crystallized (Plate 1 , Figures 7 and 8 ). High $\mathrm{P}_{2} \mathrm{O}_{5}$ contents are expressed in abundant apatite; high $\mathrm{TiO}_{2}$ is similarly expressed in ilmenite, titanomagnetite, kaersutitic hornblende, and, in the altered glass, as abundant anatase. Although the $\mathrm{CO}_{2}$ may have been picked up by assimilation of carbonate sediments, it is more likely that all of the volatiles and trace elements are of mantle origin.

Alteration is unique among igneous rocks recovered during Leg 17. At most sites, the rocks were initially relatively anhydrous tholeiites, and were altered in the presence of high activities of $\mathrm{CO}_{2}$ and $\mathrm{H}_{2} \mathrm{O}$. This led to nonzeolitic calcite-montmorillonite-celadonite assemblages formed diagenetically at or near ambient seawater temperatures. Pyroxene and interstitial residua were altered, whereas plagioclase, except for the calcic cores of the largest crystals, was relatively little attacked. Prior to alteration the rocks were extensively fractured and the secondary products often formed veins.
At Hole $165 \mathrm{~A}$, on the other hand, $\mathrm{CO}_{2}$ activity was low, primary assemblages were relatively hydrous and stable, the rocks were relatively unfractured, and the alteration took place, at least in part, at slightly elevated temperatures. As a result, secondary calcite is minor, veins are few, and primary hydrous minerals remain unaltered. The secondary assemblages are dominated by zeolites, mica, chlorite, and minor montmorillonite. Although the mica and chlorite may in part be deuteric, the overall assemblage indicates a relatively low-grade subfacies of the zeolite facies. Mafic minerals were relatively stable which accounts for the survival of pyroxene as well as the hydrous phases hornblende and biotite; montmorillonite is, consequently, minor. Late alkali-rich residua gave rise to mica and chlorite. Plagioclase was unstable, yielding components that formed calcic zeolites (chabazite, gmelinite, minor thomsonite), sodic zeolites (natrolite) and analcime. Calcic anorthoclase, as rims on plagioclase and as late interstitial grains, survived to a variable extent (Plate 2, Figure 1). The zeolitization is more intense downward, with the lowest rocks cored retaining almost no feldspar. This pattern suggests a heat source at depth, but the rate of increase of zeolitization with depth is so great that the metamorphism is unlikely to be normal burial metamorphism controlled by the regional geothermal gradient. Rather, a shallow intense heat source is indicated, probably related to the alkalic volcanism. These facts suggest that the metamorphism occurred during and shortly after the volcanism. To the extent that open joints and vesicles were available, veins and amygdules were deposited. Their mineralogy is for the most part consistent with the low-grade zeolite facies metamorphism, and includes montmorillonite, chlorite, mixed-layer chlorite-montmorillonite, calcite, and pyrite at shallow depth. Somewhat deeper these minerals are joined by thomsonite and gmelinite, thus reflecting the same depth zonation seen in the wall rocks.

After termination of the metamorphism and general cooling, diagenetic changes led to replacement of plagioclase by pure $\mathrm{K}$-feldspar, but the extent of this was limited by the fact that little Ca-rich, K-poor plagioclase, which might be susceptible to such alteration, survived the metamorphism, whereas K-rich sodic plagioclase, which did survive, is replaced slowly, if at all. The K-feldspar is more abundant at shallower depths where more calcic plagioclase survived the metamorphism. Some, or all, of the montmorillonite, in both veins and wall rocks, may have been formed during the post-metamorphic diagenesis.

The composition and generally unfractured and unveined nature of these hawaiites suggest that they were not erupted at a spreading center and did not suffer the mechanical effects of the spreading process. One might tentatively infer that these flows or intrusions overlie sediments that in turn overlie the true basement in this area. The distance from the nearest guyot or seamount suggests that the differentiation leading to formation of hawaiites is not necessarily related to a large volcanic super-structure, but can occur in the mantle or oceanic crust. Furthermore, alkalic volcanism need not construct a seamount or volcanic chain but can produce flows or shallow sills concordant with the local sediments and basement and having no distinct geomorphic expression. Although, in the present case, one may argue that the volcanism is merely satellitic to that which built the Line Islands, and coincidentally ceased before the local effects were topographically advanced, one must still entertain the possibility that alkalic volcanism without morphologic expression on the sea floor will be found elsewhere, where even a satellitic relation to seamounts and island chains will not exist. We are confronted with such questions as: How ubiquitous is alkalic volcanism? How leaky is the oceanic lithosphere?

\section{Low-Grade Metasomatism and Spilites}

Hole $165 \mathrm{~A}$ also raises general questions about the mobility of elements during diagenesis and low-grade metasomatism. The secondary zeolitic mineral assemblage at Hole 165A contrasts strongly with both the nonzeolitic secondary assemblages at other Leg 17 sites and with some secondary assemblages in zeolitized tholeiitic oceanic rocks (Miyashiro and Shido, 1970; Miyashiro, Shido and Ewing, 1971; Bass, unpublished data). The contrasts between the assemblage at Hole 165A and the others can be interpreted in terms of Zen's (1961) conclusion that, given otherwise identical conditions, a secondary nonzeolitic, calcite-clay assemblage will form instead of a zeolitic one, even under conditions 
of the zeolite facies, if $\mathrm{CO}_{2}$ activity is high. This interpretation coupled with observations on the relative survival of pyroxene and plagioclase, has ramifications into the spilite problem.

The nonzeolitic diagenetic alteration at the other Leg 17 sites involved a high degree of mobility of $\mathrm{Ca}$, due, evidently, to high porosity and permeability and a high $\mathrm{CO}_{2}$ activity controlled by carbonate-rich sediment sections. The $\mathrm{Ca}$ at those sites was mobilized and lost, primarily from pyroxene, whereas plagioclase remains largely unaltered, so that most $\mathrm{Al}$ was not mobilized or lost to the extent that it is during spilitization. The zeolitic alteration of the tholeiitic rocks, like that of the alkalic rocks at Hole 165A, involved alteration of plagioclase and extensive survival of pyroxene. However, this alteration, contrary to that at Hole $165 \mathrm{~A}$, produced sodic rather than calcic zeolites. The resulting rocks are chemically similar to pyroxene-bearing spilites, though mineralogically distinct because, in the absence of greenschist facies conditions, albite was not stabilized. In contrast, in the alkalic rocks at Hole $165 \mathrm{~A}$, plagioclase was altered to calcic zeolites and pyroxene survived during the low-grade zeolitic metamorphism, which evidently occurred under low $\mathrm{CO}_{2}$ activity controlled by a sediment section rich in volcanic detritus and poor in carbonate. But again, spilitic compositions were not produced.

We thus find two types of zeolitic assemblages, one chemically convergent with spilites, the other quite distinct. Almost certainly, the difference does not lie in the presence of alkalic rather than tholeiitic rocks, but in the stabilization of calcic rather than sodic zeolites. This, in turn, is related to the openness of the system and other causes of ion mobility. Mobility related to $\mathrm{CO}_{2}$ activity is minor at Hole $165 \mathrm{~A}$. Other important factors are porosity and permeability, but even these are not critical by themselves. The prime factors are chemical potential gradients, which provide the driving potential, and the combination porosity-permeability-time, which together determine "effective permeability". At Hole 165 A, time (the duration of high temperatures related to the volcanism) and porosity (fractures and vesicles) were limited, and possibly permeability as well; therefore, effective permeability was low and little, or no, long-distance mass transport could occur, even if large scale chemical potential gradients were present. Textural and mineralogic evidence, however, raises doubts that significant longdistance chemical potential gradients existed. Calcic zeolites form pseudomorphs after plagioclase and natrolite occupies interstitial patches. From these facts we infer that local gradients did exist and that mobility was adequate to manifest them, whereas, if longdistance gradients had been present, we expect that they would have led to mineral segregation on that scale rather than the local mixing of the contrasting zeolites.

What conditions are different in those portions of the oceanic crust where spilitization occurs? Tentatively, one may conclude that spilites form where long-distance chemical potential gradients exist for a sufficient time to effect large mass transfers. The gradients are probably controlled by thermal gradients, and mobility is probably accelerated by absolute temperatures higher than those that prevailed at Hole 165A during zeolite facies metamorphism. The most likely environment in which to provide long distance thermal gradients and high absolute temperatures for extended periods of time is the high-heat-flow zone near a spreading center. Outside of that zone the reactions proceed at a slow rate.

In summary, the most common causes of effective chemical mobility in the oceanic crust appear to be high $\mathrm{CO}_{2}$ activity and high temperatures. High $\mathrm{CO}_{2}$ activity operates mainly during low temperature diagenesis under conditions of free access of seawater or, more importantly, under a cover of carbonate sediments. Mafic minerals are attacked faster than plagioclase, and loss of $\mathrm{Ca}$, unaccompanied by loss of $\mathrm{Al}$, is primarily from pyroxene. High temperatures operate mainly near spreading centers. Activity of $\mathrm{CO}_{2}$ is low, so mafic minerals are stable, whereas, plagioclase is attacked and, depending on temperature, is replaced by sodic zeolites or albite (and oligoclase). Loss of $\mathrm{Ca}$ is primarily from plagioclase and is accompanied by some loss of $\mathrm{Al}$; bulk compositions and mineralogies (albite-chlorite-clinopyroxene) become more spilitic. The bulk compositions produced under high $\mathrm{CO}_{2}$ activity are more aluminous, and greenschist facies assemblages derived from them would contain more epidote (saussuritic types of "spilites"). Both types of alteration are promoted by high effective permeability which may be provided by primary porosity (interpillow spaces) and by fracturing related to the spreading process.

At Hole $165 \mathrm{~A}$, neither set of conditions was completely fulfilled in the sections penetrated. $\mathrm{CO}_{2}$ activity was low, fracturing was minor, and effective permeability low. Absolute temperatures were low. Thermal gradients were steep so that long-distance chemical gradients did not exist, and time was probably relatively short. The result was zeolite facies metamorphism under essentially closedsystem conditions except for the addition of water. Little $\mathrm{CO}_{2}$ was added, nor was primary $\mathrm{CO}_{2}$ lost, although it might be isotopically exchanged.

In a very real sense, unusual cases of metamorphism like that at Hole $165 \mathrm{~A}$, which provides an uncommon combination of circumstances, offer an important test for explanations of the more common cases of metamorphism and diagenesis found in rocks of the oceanic crust.

\section{Petrography}

17-165A-23 (Top of core): Megascopic appearance is unknown. Irregular joints are filled with Fe-stained montmorillonite(?). Plagioclase, pyroxene, and opaque "microphenocrysts" form glomerocrysts or xenoliths up to $3.0 \times 4.0 \mathrm{~mm}$; these mineral grains and their green micaceous groundmass are like the isolated microphenocrysts and the interstitial mass of the host, suggesting either that the clusters are glomerocrysts or that the isolated "microphenocrysts" are disaggregated xenoliths.

\begin{tabular}{|c|c|c|}
\hline $\begin{array}{l}\text { Component } \\
(\mathrm{min} / \mathrm{max} \text { size }-\mathrm{mm})\end{array}$ & $\begin{array}{c}\text { Average } \\
\text { Size }(\mathrm{mm})\end{array}$ & $\begin{array}{l}\text { Volume } \\
(\%)\end{array}$ \\
\hline $\begin{array}{l}\text { Plagioclase phenocrysts } \\
(1.2 \times 0.07 / 4.0 \times 3.0)\end{array}$ & & 1.5 \\
\hline $\begin{array}{l}\text { Plagioclase microphenocrysts } \\
(1.4 \times 0.12) \max \end{array}$ & $0.1 \times 0.08$ & 2.4 \\
\hline $\begin{array}{l}\text { Pyroxene microphenocrysts } \\
(0.06 \times 0.06 / 0.3 \times 0.2)\end{array}$ & & 2.7 \\
\hline $\begin{array}{l}\text { Opaque microphenocrysts } \\
\text { equant }(0.1 / 0.23)\end{array}$ & & 1.2 \\
\hline $\begin{array}{l}\text { Amphibole microphenocrysts } \mathrm{c} \\
(0.04 \times 0.01) \max \end{array}$ & & Trace \\
\hline $\begin{array}{l}\text { Pseudomorphs after olivine } \\
\text { microphenocrysts } \\
(0.35 \times 0.17) \max \end{array}$ & & 0.4 \\
\hline Opaque groundmass grains & 0.003 & 12.2 \\
\hline $\begin{array}{l}\text { Groundmass (except opaque } \\
\text { grains } \mathrm{e}\end{array}$ & & 75.3 \\
\hline Apatite needles & & Trace \\
\hline $\begin{array}{l}\text { Vesicles and their fillings } \\
\text { (1.1) }\end{array}$ & & 3.0 \\
\hline Brown amphibole along seams ${ }^{\mathrm{f}}$ & $0.08 \times 0.012$ & 0.15 \\
\hline K-feldspar & & Trace \\
\hline
\end{tabular}

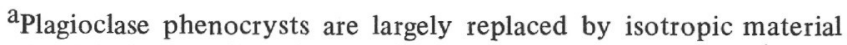
(analcite? epoxy?) and crossed by irregular veins of a birefringent mineral; minor replacement is by montmorillonite(?).

$\mathrm{b}_{\text {The cores are partly replaced by } \mathrm{K} \text {-feldspar. }}$

${ }^{\mathrm{c}}$ Amphibole microphenocrysts are seen only in glomerocrysts or xenoliths; where amphibole is abundant, pyroxene is sparse or absent.

$\mathrm{d}_{\text {Pseudomorphs after olivine are subhedral to euhedral pseudo- }}$ morphs of green micaceous material (montmorillonite;) in glomerocrysts or xenoliths.

${ }^{\mathrm{e}}$ Groundmass (except opaque grains) is mainly green micaceous material (mica? chlorite? montmorillonite?); lesser pyroxene, minor plagioclase, and possibly a trace of amphibole. 
$\mathrm{f}_{\text {Elongate seams or lenses with pleochroic brown amphibole prisms }}$ set perpendicular to the walls; the centers of the seams are locally open; they appear to be elongate, irregular vesicles which are partly to completely filled by pneumatoly tic or deuteric hydrothermal amphibole (compare Plate 1, Figures 7 and 8).

17-165A-14-1, $117 \mathrm{~cm} \mathrm{(1):} \mathrm{This} \mathrm{specimen} \mathrm{is} \mathrm{altered} \mathrm{glassy} \mathrm{rock}$ that is in contact with a green micaceous mass which may be a xenolith, joint filling, or interflow sediment. It contains clasts(?) of plagioclase, pyroxene, amphibole, and opaque minerals. The "glass" is patchy to streaky in shades of brown and gray. It contains phenocrysts of relatively large, fresh, sector-zoned pyroxene, and altered plagioclase. The plagioclase is almost wholly replaced by calcite, montmorillonite(?), and, possibly, some K-feldspar. Some amygdules in the "glass" are lined by chalcedony(?), with fibers oriented perpendicular to the walls. X-ray analysis (Appendix A) of the main "glass", including the phenocrysts, indicates montmorillonite, plagioclase, clinopyroxene, ilmenite; minor K-feldspar, amphibole, mica, apatite; and traces of anatase. The gray streaky "glass" near the green mass contains montmorillonite, plagioclase, clinopyroxene, ilmenite, amphibole, Ti-poor titanomagnetite; and traces of mica, anatase, calcite, and K-feldspar. The brown streaky "glass" near the green mass includes plagioclase, clinopyroxene, mica, anatase; minor montmorillonite, amphibole; and traces of calcite, ilmenite, and goethite (and possibly K-feldspar and quartz). The anatase, montmorillonite, K-feldspar, and goethite are probably diagenetic alterations products of ilmenite, titanomagnetite, glass and plagioclase.

17-165A-24-1, 117-121 cm (host): Specimen is finely flow banded, dark brown to red brown, porphyritic, altered glassy rock; flow lines bend around inclusions, vesicles and phenocrysts. The abundant amygdules are mainly round, and are composed of either calcite, montmorillonite or both. Hollow vesicles are relatively uncommon.

\begin{tabular}{|c|c|c|}
\hline $\begin{array}{c}\text { Component } \\
(\mathrm{min} / \mathrm{max} \text { size }-\mathrm{mm})\end{array}$ & $\begin{array}{l}\text { Average } \\
\text { Size }(\mathrm{mm})\end{array}$ & $\underset{(\%)}{\text { Volume }}$ \\
\hline $\begin{array}{l}\text { Plagioclase phenocry sts (including } \\
\text { alteration)a } \\
(0.12 \times 0.015 / 0.8 \times 0.25)\end{array}$ & $0.55 \times 0.25$ & 3.5 \\
\hline $\begin{array}{l}\text { Pyroxene phenocrysts } \\
(0.15 \times 0.03 / 0.45 \times 0.24\end{array}$ & $0.2 \times 0.1$ & 1.5 \\
\hline Altered glass $\mathrm{b}$ & & 88.7 \\
\hline $\begin{array}{l}\text { Pseudomorphs of montmorillonite } \\
\text { and calcite after olivine(?) } \\
\text { phenocrysts } \\
(0.4 \times 0.3)\end{array}$ & & 1.7 \\
\hline $\begin{array}{l}\text { Opaque minerals } \mathrm{c} \\
<(0.7 \times 0.02) / 0.2 \times 0.12\end{array}$ & & 0.2 \\
\hline $\begin{array}{l}\text { Calcite amygdules } \\
(0.15 / 0.85)\end{array}$ & & 1.2 \\
\hline $\begin{array}{l}\text { Montmorillonite amygdules } \mathrm{d} \\
(0.06 / 0.45)\end{array}$ & 0.25 & 3.2 \\
\hline Ilmenite $\mathrm{e}^{\mathrm{a}}$ & & $?$ \\
\hline
\end{tabular}

aThe cores, or irregularly distributed patches, are altered to K-feldspar, rare montmorillonite(?), and, possibly, a zeolite(?) or analcite(?).

b Dark brown or red brown, commonly opaque; where translucent, it contains mats of very fine-grained opaque plates, which probably correspond to the ilmenite seen in X-ray patterns (Appendix A).

$\mathrm{c}_{\mathrm{Generally}}$ altered to translucent red $\mathrm{Fe}$ oxides.

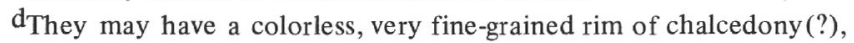
or a calcite core.

eSeen as plates in the altered glass and abundant enough to appear distinctly in the X-ray patterns (Appendix A).
17-165A-24-1, 117-121 cm (inclusion; main lithology): This specimen is dark gray, very fine-grained, with ovoid to elongate lenses and pods of relatively coarse pegmatoid material which is relatively rich in calcite and hornblende (see separate description and mode below). The texture of the main lithology is almost granular, which, in view of the occurrence as an inclusion in a "glassy" lava, might suggest a hornfels; however, zoning of plagioclase and pyroxene and other mineralogic features exclude this interpretation. The contact against the "glassy" host lava is marked by a zone rich in calcite and montmorillonite, much like the sediment or joint filling in 17-165A-24, 1, $117 \mathrm{~cm}$ (1; see above), but without "clasts" (Plate 1, Figure 5).

\begin{tabular}{|c|c|c|}
\hline $\begin{array}{c}\text { Component } \\
(\mathrm{min} / \mathrm{max} \text { size }-\mathrm{mm})\end{array}$ & $\begin{array}{c}\text { Average } \\
\text { Size }(\mathrm{mm})\end{array}$ & $\underset{(\%)}{\text { Volume }}$ \\
\hline $\begin{array}{l}\text { Plagioclase phenocrysts (includes } \\
\text { trace of secondary K-feldspar) } \\
(0.65 \times 0.3 / 1.8 \times 1.5)\end{array}$ & & 1.0 \\
\hline $\begin{array}{l}\text { Pyroxene phenocrysts } \\
(0.4 \times 0.35 / 0.6 \times 0.45)\end{array}$ & & 0.1 \\
\hline $\begin{array}{l}\text { Plagioclase (non-phenocrystic) })^{b} \\
(0.1 \times 0.03 / 0.5 \times 0.05)\end{array}$ & & 36.0 \\
\hline $\begin{array}{l}\text { Pyroxene } \\
\quad \text { prismatic } \\
(0.02 \times 0.01 / 0.05 \times 0.02 \\
\text { equant } \\
(<(0.01 \times 0.01) / 0.06 \times 0.05)\end{array}$ & $0.015 \times 0.015$ & 27.3 \\
\hline $\begin{array}{l}\text { Opaque grains }{ }^{\mathrm{c}} \\
(0.01)\end{array}$ & 0.1 & 16.7 \\
\hline $\begin{array}{l}\text { Amphibole } \\
\text { fibrous } \\
(0.1 \times 0.04 / 0.5 \times 0.06) \\
\text { equant } \mathrm{d}\end{array}$ & $\begin{array}{r}0.35 \times 0.04 \\
0.2 \times 0.17\end{array}$ & 2.5 \\
\hline Mica (interstitial) & & 12.8 \\
\hline $\begin{array}{l}\text { Apatite } \\
(1 \times 0.008)\end{array}$ & & 2.6 \\
\hline Calcite & & 0.9 \\
\hline Biotite & & Trace \\
\hline
\end{tabular}

aPartly altered to $\mathrm{K}$-feldspar, a trace of green montmorillonite(?), and possibly a zeolite(?).

b The cores are partly altered to K-feldspar and possibly a zeolite.

'Titanomagnetite (see Appendix A).

$\mathrm{d}_{\text {The brown }}$ grains are probably kaersutitic in this $\mathrm{TiO}_{2}$-rich rock (Table 1).

eNotably sparse in the main lithology of the inclusion compared to its abundance in the pegmatoid patches (see below).

17-165A-24-1, 117-121 cm (inclusion; pegmatoid pods): Pegmatoid pods in the inclusion vary widely in size, shape, relative mineral abundances, and the sharpness of their boundaries, but in all cases reflect a volatile-rich magma under high confining pressure that enable the magma to retain volatiles during crystallization. Most pods are fairly sharply bounded; a few are rapidly gradational to the main lithology of the inclusion (Plate 1, Figure 6). The pods to which the mode pertains are relatively coarse-grained, hornblendepoor, calcite-rich, and gradational to the main lithology; nonetheless, they are relatively rich in hornblende compared to the main lithology. Certain calcite ovoids resemble amygdules. their contacts are sharp; but they contain silicates and thus seem related to the calcite in the pegmatoid patches, and, in two cases, hornblende prisms are intergrown with the calcite in the outermost parts of the ovoids and tend to lie perpendicular to their sharp contacts (Plate 1, Figures 7 and 8 ). The texture strongly suggests, not only concurrent crystallization of calcite and amphibole, but an immiscible carbonatite magma as well. The ovoids are in some respects similar to the seams of brown amphibole in 17-165A-23 
(top of core) (see above). The late calcite vein in this specimen, which cuts both the host rock and the inclusion and contains opaque minerals (see discussion of host above), may also be a product of a late, immiscible carbonatite magma, as may be certain large calcite patches (up to $2 \mathrm{~cm}$ in diameter) which are sparsely scattered through the specimen. An alternative interpretation of the hornblende-bearing calcite ovoids is that they were originally drusy cavities, like those amphibole-rich seams in 17-165A-23 (top of core) which still retain hollow centers; but, unlike those seams, the ovoid cavities in this specimen were later, presumably during diagenesis, filled with calcite. To test these possibilities, various types of calcite from this specimen were submitted to $\mathrm{H}$. Craig (Scripps Institution of Oceanography) for $\mathrm{C}$ and $\mathrm{O}$ isotope analysis, with results as follows:

\begin{tabular}{lccc}
\hline & $\begin{array}{c}\mathrm{O}^{18} \\
\text { (SMOW) }^{\mathrm{a}}\end{array}$ & $\begin{array}{c}\mathrm{O}^{18} \\
(\mathrm{PDB})^{\mathrm{a}}\end{array}$ & $\begin{array}{c}\mathrm{C}^{13} \\
(\mathrm{PDB})^{\mathrm{a}}\end{array}$ \\
\hline Center of 2 cm calcite patch & 27.88 & -2.57 & +1.36 \\
Vein & 28.14 & -2.33 & +2.06 \\
\hline
\end{tabular}

aReference standards: $\mathrm{SMOW}=$ standard mean ocean water $; \mathrm{PDB}=$ University of Chicago belemnite standard from the Cretaceous Peedee Formation, South Carolina.

Isotopically, the calcites are like typical marine sedimentary carbonate rather than carbonatite carbonate (Taylor et al., 1967). Either the calcite is not a product of an immiscible carbonatite magma, or, if it is, it has been isotopically equilibrated with seawater. Viewed simply as isotopically equilibrated, normal marine carbonates, the calcites would indicate temperatures of $27.3^{\circ}$ and $28.5^{\circ} \mathrm{C}$ (Epstein et al., 1953). Assuming isotopic equilibrium, these temperatures indicate equilibration with improbably warm bottom waters, equilibration with formation waters which were isotopically different from normal seawater, and/or post-burial equilibration at slightly elevated temperatures controlled either by the regional geothermal gradient or by the event which led to zeolite facies metamorphism of the igneous rocks about 30 meters below.

Some of the pegmatoid pods contain fine-grained, relatively hornblende-rich areas that grade to surrounding hornblende-poorer, coarser-grained parts of the pod. One very fine-grained, hornblenderich area is so sharply defined as to suggest a xenolith in that pod. Crystallization histories of the pegmatoid pods were evidently complex and locally variable. The magma was apparently already highly oxidized at the time of eruption, and did not develop its highly oxidized state during the late stages of its consolidation.

\begin{tabular}{|c|c|c|}
\hline $\begin{array}{c}\text { Component } \\
(\mathrm{min} / \mathrm{max} \text { size }-\mathrm{mm})\end{array}$ & $\begin{array}{c}\text { Average } \\
\text { Size }(\mathrm{mm})\end{array}$ & $\begin{array}{l}\text { Volume } \\
(\%)\end{array}$ \\
\hline $\begin{array}{l}\text { Plagioclase }^{\mathrm{a}} \\
(0.1 \times 0.07 / 0.55 \times 0.12)\end{array}$ & $0.35 \times 0.08$ & 41.9 \\
\hline $\begin{array}{l}\text { Pyroxene }^{b} \\
(0.04 \times 0.03 / 0.2 \times 0.1)\end{array}$ & $0.14 \times 0.08$ & 7.9 \\
\hline $\begin{array}{l}\text { Hornblende } \\
(0.07 \times 0.05 / 1 \times 0.12)\end{array}$ & $0.5 \times 0.1$ & 17.0 \\
\hline $\begin{array}{l}\text { Relatively large skeletal opaqu } \\
\text { grains } \\
(0.06 \times 0.06 / 0.45 \times 0.06)\end{array}$ & $0.12 \times 0.1$ & 5.3 \\
\hline $\begin{array}{l}\text { Fine platy opaque grains } \\
(0.02 \times<0.01 / 0.13 \times 0.02)\end{array}$ & $0.04 \times<0.01$ & 5.6 \\
\hline $\begin{array}{l}\text { Calcite patches } \mathrm{c} \\
(0.5 \mathrm{max})\end{array}$ & & 10.6 \\
\hline Mica & & 7.0 \\
\hline $\begin{array}{l}\text { Apatite } \\
(0.3 \times 0.02 \mathrm{max})\end{array}$ & & 4.7 \\
\hline
\end{tabular}

aLittle or no replacement by K-feldspar. Often contain apparent miarolite cavities lined by crystals with rhomboid terminations.
bConcentrated on the edges of the pegmatoid pods, and is absent or almost so in their centers where hornblende is relatively abundant.

${ }^{\mathrm{C}}$ The calcite patches are irregular and are definitely not amygdules. The calcite does not replace other minerals and is possibly magmatic.

17-165A-26-2, $80 \mathrm{~cm}$ : Specimen is dark gray, relatively coarse-grained lava or shallow intrusion. Random plagioclase laths are set in a mass of granular pyroxene and amphibole, with minor apatite-rich interstitial residuum. Mafic minerals are too large to be intergranular and are not ophitic or subophitic relative to plagioclase; so, the texture is not accurately described as diabasic intergranular. The high $\mathrm{Fe} /(\mathrm{Fe}+\mathrm{Mg})$ and the plagioclase composition (Appendix A) indicate hawaiite, not basalt.

\begin{tabular}{lcc}
\hline \multicolumn{1}{c}{$\begin{array}{c}\text { Component } \\
(\mathrm{min} / \mathrm{max} \text { size }-\mathrm{mm})\end{array}$} & $\begin{array}{c}\text { Average } \\
\text { Size }(\mathrm{mm})\end{array}$ & $\begin{array}{c}\text { Volume } \\
(\%)\end{array}$ \\
\hline $\begin{array}{l}\text { Plagioclase and alkali feldspar } \\
\text { Pyroxene }\end{array}$ & $0.2 \times 0.03$ & 18.6 \\
$(0.1 \times 0.1 / 0.3 \times 0.15)$ & 20.0 \\
$\begin{array}{l}\text { Hornblende } \\
(0.05 \times 0.05 / 0.3 \times 0.05)\end{array}$ & 13.4 \\
$\begin{array}{l}\text { Opaque minerals } \\
(1.2 \times 0.03 \text { max })\end{array}$ & 13.6 \\
$\begin{array}{l}\text { Pasty mixture of chlorite, } \\
\text { K-feldspar, apatite }\end{array}$ & \\
$\begin{array}{l}\text { Biotitef } \\
\text { Chlorite }+ \text { montmorillonite } \\
\text { amygdules }\end{array}$ & 31.6 \\
\hline
\end{tabular}

aAll but narrow rims are altered to light green isotropic chlorite and K-feldspar (Appendix A) which are counted separately as component 5 . The extinction angles of the rims pass through $0^{\circ}$, indicating that the outermost zones are more sodic than $A_{20}$. The $\mathrm{X}$-ray data (Appendix A) and extinction angles suggest that the original plagioclase was $\mathrm{K}$-rich andesine grading outward through oligoclase to a mantle of Ca-rich alkali feldspar (roughly Or33).

bMinor alteration to light green chlorite like that which replaces plagioclase.

CProbably kaersutitic; often mantles pyroxene.

dThe X-ray data (Appendix A) indicate ilmenite and Ti-poor titanomagnetite; the ilmenite is probably more abundant. This component may include some sulfide.

eThe total apatite in the rock may be as much as 2 to $3 \%$.

fDeep red brown to colorless, strongly pleochroic flakes. The centers of some flakes, or certain layers in them, are a light green or colorless flaky mineral (chlorite?).

17-165A-26-2, 80-84 cm: Specimen consists of dark gray, fine-grained hawaiite; irregularly shaped vesicles range from 0.1 to $(1 \times 3) \mathrm{mm}$ in size; they are generally lined by a blue green, flaky, microbotryoidal material and may contain sulfide grains. Calcite ovoids up to $2 \mathrm{~mm}$ in diameter and veins of various types occur in the rock but were not counted in the mode. One calcite vein encloses opaque minerals and contains a green micaceous mineral along its edges, in its interior, and in considerable abundance around the edges of the opaque grains; the vein grades to an elongate "vesicle" zonally lined by a red brown fibrous aggregate on the inside, and an olive green "groundmass" on the outside (see mode). One soft white vein includes calcite, pyrite, chlorite, montmorillonite, and mixed-layer chlorite-montmorillonite. A vuggy vein (or open joint filling) is mainly composed of light blue green, micaceous, microbotryoidal or micromammillary chlorite plus montmorillonite, plus tarnished pyrite crystals. These vein fillings are probably of the same generation as the groundmass and other fibrous to flaky materials which are counted in the mode. 


\begin{tabular}{|c|c|c|}
\hline $\begin{array}{c}\text { Component } \\
(\mathrm{min} / \mathrm{max} \text { size }-\mathrm{mm})\end{array}$ & $\begin{array}{l}\text { Average } \\
\text { Size }(\mathrm{mm})\end{array}$ & $\begin{array}{l}\text { Volume } \\
(\%)\end{array}$ \\
\hline $\begin{array}{l}\text { Plagioclase and alkali feldspar }{ }^{\mathrm{a}} \\
(0.09 \times 0.02 / 0.6 \times 0.3)\end{array}$ & & 29.6 \\
\hline $\begin{array}{l}\text { Pyroxene } \\
(0.01 \times 0.01 / 1.08 \times 0.09)\end{array}$ & $0.25 \times 0.15$ & 21.6 \\
\hline $\begin{array}{l}\text { Hornblendeb } \\
(<(0.2 \times 0.01) / 0.8 \times 0.07)\end{array}$ & $0.14 \times 0.03$ & 6.7 \\
\hline $\begin{array}{l}\text { Opaque minerals }^{\mathrm{c}} \\
\text { platy } \\
(0.12 \times 0.01 / 0.80 \times 0.15) \\
\text { equant } \\
(<(0.01 \times 0.01) / 0.4 \times 0.3)\end{array}$ & $\begin{array}{l}0.45 \times 0.025 \\
0.35 \times 0.25\end{array}$ & 11.2 \\
\hline $\begin{array}{l}\text { Biotite } \\
(<(0.2 \times 0.01) / 0.15 \times 0.02)\end{array}$ & & 9.3 \\
\hline Green micaceous groundmass ${ }^{d}$ & & 14.3 \\
\hline Apatite & & 2.1 \\
\hline Red brown aggregates $\mathrm{e}^{\mathrm{e}}$ & & 2.8 \\
\hline $\begin{array}{l}\text { Interstitial calcite } \\
(0.03 \times 0.015 / 0.2 \times 0.07)\end{array}$ & & 0.2 \\
\hline Blebs in plagioclase $\mathrm{f}$ & & 0.5 \\
\hline $\begin{array}{l}\text { Vesicles } \\
(<0.1 / 3 \times 1)\end{array}$ & 0.1 & 1.6 \\
\hline
\end{tabular}

aOptical and X-ray data (Appendix A) indicate K-rich andesine zoned outward to alkali feldspar (Or33 roughly) which occurs both as rims on larger grains and as late, independent interstitial grains. Tiny patches of diagenetic, essentially pure K-feldspar uncommonly replace the cores of plagioclase. Much more commonly the plagioclase cores are replaced by micaceous material which is either green, like the groundmass, or deep red brown, like vesicle linings. bOften mantles pyroxene, and also forms later independent grains. Ilmenite, lesser Ti-poor titanomagnetite (Appendix A), and a trace of pyrite.

$\mathrm{d}_{\text {Encloses rare brownish carbonate grains, with high indices of }}$ refraction, which may be siderite.

e Fibers or flakes which line vesicles and open joints; fill small vesicles; form irregular, ovoid or amoeboid patches in the groundmass; and replace the cores of some plagioclase grains. Under the binocular microscope and in hand specimen, they look blue green; they may be chlorite, montmorillonite, or possibly mica.

${ }^{\mathrm{f}} \mathrm{Blebs}$ or strings of blebs with high refractive indices in plagioclase; anatase?

17-165A-27-2, 60-65 cm: Specimen consists of medium gray, fine-grained hawaiite, slightly porphyritic; the relatively sodic plagioclase (Appendix A) suggests that the rock may approach a low-silica mugearite. Veins are uncommon. One vein includes thomsonite, calcite, and pyrite; minor montmorillonite; and traces of chlorite and gmelinite (Appendix A). The opaque oxide assemblage (Appendix A) indicates that the magma was relatively oxidized. The rock is essentially similar to $17-165 \mathrm{~A}-26-2,80-84 \mathrm{~cm}$, but is more altered.

\begin{tabular}{lcc}
\hline $\begin{array}{c}\text { Component } \\
(\min / \mathrm{max} \text { size }-\mathrm{mm})\end{array}$ & $\begin{array}{c}\text { Average } \\
\text { Size }(\mathrm{mm})\end{array}$ & $\begin{array}{c}\text { Volume } \\
(\%)\end{array}$ \\
\hline $\begin{array}{l}\text { Plagioclase (remnants }) \\
\text { phenocrysts }\end{array}$ & & \\
$\quad(0.7 \times 0.85 / 2.0 \times 0.55)$ & & 13.2 \\
groundmass & & \\
$(0.07 \times 0.03 / 0.7 \times 0.13)$ & $0.1 \times 0.1$ &
\end{tabular}

Non-flaky, colorless replacements of plagioclasea
Pyroxene

$(0.03 \times 0.03 / 0.55 \times 0.3)$

$0.2 \times 0.1$

24.4

Hornblende ${ }^{b}$

$(0.01 \times 0.01 / 0.55 \times 0.04)$

$0.14 \times 0.03$

Opaque minerals $\mathrm{c}$

platy

(very small $/ 0.6 \times 0.05$ )

$0.13 \times 0.01$

equant

$(0.06 \times 0.04 / 0.3 \times 0.2)$

$0.1 \times 0.09$

16.6

Secondary flaky minerals $d$

Biotite $^{\mathrm{e}}$

0.6

Apatite

0.5

Fibrous zeolite ${ }^{f}$

1.5

Calciteg

0.5

aK-feldspar (?), zeolites, and possibly analcite. The zeolites, probably, are mainly chabazite and gmelinite, with possibly some natrolite (see Appendix A).

$\mathrm{b}_{\text {Later than, and in some cases mantled onto, pyroxene; it is red }}$ brown to yellow and probably kaersutitic. Late magmatic ends of some prisms are green.

cMainly ilmenite and Ti-poor titanomagnetite (Appendix A); also trace of yellow sulfide, probably pyrite.

dMainly mica and chlorite according to the X-ray data (Appendix A); montmorillonite is present in trace amounts only.

e Deep red brown flakes in late interstitial patches of fibrous zeolite.

fIrregular patches up to a few millimeters across and interstitial. Biotite is seen only as inclusions in such patches. The crystal habit and X-ray data (Appendix A) suggest that the zeolite is mainly natrolite (or thomsonite).

gIn patches, alone or with fibrous zeolite.

17-165A-27-CC: Specimen consists of dark gray, fine-grained, seriate hawaiite(?) with a few phenocrysts of titanaugite and hornblende up to $3.7 \mathrm{~mm}$ long. The rock also contains chabazite, gmelinite, natrolite, thomsonite; minor plagioclase, Ti-poor titanomagnetite, ilmenite, mica, chlorite; and traces of K-feldspar, pyrite, apatite, montmorillonite (see Appendix A). Plagioclase was originally relatively calcic (K-rich andesine and perhaps labradorite) and zoned outward to thin rims of calcic anorthocalse. It is now wholly replaced by zeolites except for thin, discontinuous, highly zoned rims with small extinction angles (Plate 2, Figure 1). The groundmass is medium olive green, flaky, and probably composed of mica, chlorite, and minor montmorillonite. Thin apatite prisms project through all minerals, not only through plagioclase as in other specimens from this site.

Reddish brown chabazite and gmelinite replace plagioclase. Prismatic, colorless natrolite and/or thom sonite occur interstitially.

In addition to zeolites, diagenetic $\mathrm{K}$-feldspar also replaces plagioclase. The rock is also cut by a joint whose surfaces are discontinuously coated by pyrite and brown-stained calcite. Relative mineral abundances estimated by peak heights in the total rock $\mathrm{X}$-ray patterns (Appendix A) suggest that zeolites increase toward this joint.

\section{SITE 166}

This hole was drilled at a deep site in the central Pacific Basin, and the sedimentary section down to 190 meters is radiolarian ooze. Contributions that may have been volcanic in origin, namely, grains of glass, zeolite, and feldspar, total only about one percent of the ooze. The pelagic brown clays and muds (with porcellanitic chert in the upper half) that lie between 190 and 250 meters, and are of Middle Eocene to about late Early Cretaceous in age, have abundant glass and zeolites, several percent of montmorillonitic clay, and some pyroxene and feldspar.

Between 250 and 279 meters is a sedimentary section that is dominantly volcanogenic. Most of the cores were strongly disturbed and even homogenized in the coring process, but a few segments are 
sufficiently undisturbed to show graded beds 1 to $2 \mathrm{~cm}$ thick. Texturally, the rocks range from sandstone ("wacke") to clay; they are mostly bluish gray but include adjacent colors such as grays, blues, and greens. Glass is abundant and, although most of it is light and clear, dark yellow to brown glass may dominate locally. Most of the original material has been altered to montmorillonite, analcime, zeolites, and chlorite.

Either of two modes of origin, or some combination of them, may be possible for these volcanic sandstones, siltstones, and clays. They may have been pyroclastic, with the vitric-lithic ash from individual eruptions settling through the ocean into graded beds, or they may have been derived from nearby piles of hyaloclastite that were eroded by bottom currents or slumped down unstable slopes to be redeposited at this site. The abundance of light glass, and the paucity of palagonite, argue for ash (but the extensive diagenetic alteration may have selectively destroyed most of the mafic glass and palagonite). On the other hand, the distance from islands or seamounts that may have been andesitic volcanoes, and the blocky, rather than shard-like shapes of the glass grains, favor a reworked-hyaloclastite origin (however, the mid-Cretaceous paleogeography; hence, the locations of possible unstable slopes, are not at all well known, and the thinner shards may have altered rapidly to the clays and zeolites).

Between this section and basement is a nannofossil marly mudstone, heavily charged, like many near-basement deep-sea sediments, with dark brown iron and manganese oxides. It has within it some septarian nodules and some zeolitic beds like the overlying altered volcanic sediments. The fossils set a Hauterivian age limit for the extrusive basement which was reached at 307 meters.

In the basement at Site 166 , relatively chilled, microphyric, vesicle-poor, dark gray basalts alternate with calcite-cemented hyaloclastite breccias. The lowest sample is relatively coarse-grained and aphyric. The upper part cored, probably represents a series of pillows and interpillow hyaloclastites, whereas the lowest sample, probably, is a portion of the flow interior. If so, only one flow was penetrated. It is tholeiitic (Table 1).

The rocks are relatively fresh, with unaltered sideromelane present in some samples (Plate 1, Figure 1). Montmorillonite is abundant only in altered glass, where it is poorly crystallized. Alteration of hypocrystalline rocks is very minor. Despite this relative freshness, the opaque minerals (originally titanomagnetite and possibly ilmenite) are oxidized to maghemo-magnetite (plus anatase?).

Before diagenetic alteration, some of the primary glass had been converted to color-banded palagonite. This altered glass is now banded in tones of gray to greenish gray and is cut by rare veins of phillipsite, the only zeolite found.

Altered joints and veins are moderately common. Near the top they are red to brown goethite, with minor calcite and a trace of celadonite. Goethite decreases downward and calcite and celadonite increase. Celadonite is also found within the host rock in the lowest sample. No K-feldspar was identified with certainty. The steep gradient of alteration conditions in this short basement section, reflected in goethite and celadonite abundances, is notable (compare Site 167).

Calcite crystals in vugs in the calcite-cemented hyaloclastite breccias contain from 1.0 to 3.5 mole $\% \mathrm{MgCO}_{3}$.

Alteration is not extreme, in contrast to that at Sites 167 and 171 , possibly due to a carbonate-poor sediment section and low $\mathrm{CO}_{2}$ activity. It is also due, apparently, to the very fine grain size, which influenced the nature, abundance, and size of both the crystalline phases and the interstitial glassy residuum.

\section{Petrography}

17-166-29-1, $123 \mathrm{~cm}$ (top piece): Sample is composed of altered, brown microphyric basalt with chilled spherulitic to variolitic groundmass. Plagioclase microphenocrysts ( $\mathrm{An}_{64}$ to $\mathrm{An}_{75}$ ) are much more abundant than those of olivine (pseudomorphs) and pyroxene. The olivine is totally altered to light brown montmorillonite ("bowlingite") and red Fe oxides, and interstitial glass is altered to yellow, orange brown or deep red brown montmorillonite and $\mathrm{Fe}$ oxides.
17-166-29-2, 16-25 cm: Sample is dark gray, chilled, microphyric, essentially nonvesicular basalt. The groundmass grades from a glass selvage (Plate 2, Figure 2), through a spherulitic layer $(1 \mathrm{~cm}$ thick), to fine bow-tie or sheaf-like varioles, to radial plagioclase clusters set in a mass of fine feathery pyroxene varioles and altered interstitial glass. Only this specimen and, to a lesser extent, those immediately above and below, retain fresh sideromelane. On Leg 17, sideromelane was recovered only at this site and at Sites 169 and 171.

Color-laminated angular blocks in altered glass (montmorillonite) suggest that it was at least in part palagonite prior to being subjected to diagenesis. Plagioclase microphenocrysts exceed those of pyroxene and olivine. The olivine is wholly replaced by diagenetic montmorillonite (Plate 2, Figure 2) and large "iddingsite" flakes.

Steeply to moderately dipping joints are lined by goethite. Near the glassy selvage, the goethite is red and is interlayered with calcite and possibly a trace of celadonite. A few centimeters deeper the goethite grades from red to deep brown, and the abundance of calcite rapidly diminishes to zero.

17-166-29-2, 121-123 cm: Specimen consists of calcitecemented breccia enclosing angular clasts of gray to greenish gray altered glass and rare fresh sideromelane remnants. Vuggy calcite crystals contain 3.5 mole $\% \mathrm{MgCO}_{3}$. Light brown veins of diagenetic phillipsite cut some of the altered glass fragments.

17-166-29-3-72-74 cm: This specimen is dark gray, densely chilled, nonvesicular, microphyric basalt; it is like 17-166-29-1, 123 $\mathrm{cm}$ (top), but fresher. It is cut by rusty red brown goethite veins that contain calcite and have selvages of green to yellow green cross-fiber celadonite (Appendix A). The groundmass is so densely chilled that, relative to it, virtually all visibly discrete silicate grains are microphenocrystic.

\begin{tabular}{ccc}
\hline Component & Average & Volume \\
$(\min / \max$ size $-\mathrm{mm})$ & Size $(\mathrm{mm})$ & \\
\hline
\end{tabular}

Plagioclase microphenocrysts ${ }^{\mathrm{a}}$

$(0.025 \times 0.007 / 0.8 \times 0.08)$

$0.25 \times 0.03$

Pyroxene microphenocrysts

$(0.04 \times 0.04 / 0.45 \times 0.28)$

$0.13 \times 0.10$

Olivine microphenocrysts

(pseudomorphs) ${ }^{\mathrm{b}}$

$(0.03 \times 0.03 / 0.33 \times 0.3)$

$0.19 \times 0.12$

Opaque grains

equant

$(0.01 / 0.05$

0.035

$(0.32 \times 0.03) \max$

Feathery pyroxene varioles

aMinor montmorillonite replaces the cores.

bMontmorillonite and "iddingsite" pseudomorph; stained red near joints.

17-166-29-3, 83-90 cm: This specimen is a calcite-cemented hyaloclastite breccia. The calcite is mainly an unusual light reddish brown, with minor white and gray. Vugs are partly to wholly filled with gray, gray green or brown, well crystallized montmorillonite. Calcite crystals from vugs have $\mathrm{MgCO}_{3}$ contents which average 2.0 mole \% and range from 1.0 to 3.0 mole \% (Appendix A). The volcanic glass is wholly altered.

17-166-29-CC: Specimen is medium gray, relatively coarsegrained basalt or fine-grained diabase; aphyric; subvariolitic groundmass. Random plagioclase laths are set in a texturally variable matrix which locally, where relatively coarse-grained, is intergranular or rarely subophitic, whereas elsewhere, it is composed of an intergranular to intersertal variolitic mass with abundant opaque grains. Relatively coarse-grained pyroxene and plagioclase may form radial arrays. The rock is cut by calcite veins with celadonite selvages and by celadonite veins. 


\begin{tabular}{lcc}
\hline \multicolumn{1}{c}{$\begin{array}{c}\text { Component } \\
(\mathrm{min} / \mathrm{max} \text { size }-\mathrm{mm})\end{array}$} & $\begin{array}{c}\text { Average } \\
\text { Size }(\mathrm{mm})\end{array}$ & $\begin{array}{c}\text { Volume } \\
(\%)\end{array}$ \\
\hline $\begin{array}{l}\text { Plagioclase } \mathrm{a} \\
(0.1 \times 0.02 / 1.2 \times 0.1)\end{array}$ & $0.5 \times 0.05$ & 28.0 \\
$\begin{array}{l}\text { Pyroxene } \mathrm{b} \\
(0.1 \times 0.1 / 0.3 \times 0.15)\end{array}$ & $0.12 \times 0.12$ & 20.2 \\
$\begin{array}{l}\text { Olivine (pseudomorphs })^{\mathrm{c}} \\
(0.5 \times 0.12 \mathrm{max})\end{array}$ & & \\
$\begin{array}{l}\text { Opaque grains } \mathrm{d} \\
(0.01 \times 0.01 / 0.3 \times 0.03)\end{array}$ & $0.1 \times 0.02$ & 12.9 \\
Groundmass & & 36.2 \\
Amygdules $\mathrm{f}$ & 0.35 & 0.1 \\
\hline
\end{tabular}

aThe cores are commonly altered to green montmorillonite and rarely to celadonite.

bPartly altered to green montmorillonite.

cMontmorillonite and possibly celadonite pseudomorphs. Stained red near joints.

dThe unit cell edge (see Appendix A), and possible traces of anatase, indicate maghemo-magnetite near magnetite; no ilmenite was identified. This highly oxidized opaque mineral assemblage is unusual in an otherwise relatively unaltered basalt.

eThe thin sections encompass chilled near-surface zones of rapidly changing textures, so that feathery, quenched varioles are relatively abundant at one end, whereas pyroxene, plagioclase, and opaques grains in an abundant green intersertal mass of montmorillonite are relatively abundant at the other end. The quenched pyroxene is mainly subcalcic augite (Appendix A).

$\mathrm{f}_{\text {Green montm orillonite. }}$

\section{SITE 167}

The calcareous ooze, chalk, chert, and limestone beds of the Magellan Rise have very little volcanic components. The Upper Cretaceous limestones and cherts at about 690 meters and the chert, mudstone, and limestone (probably lowest Cretaceous) at about 1130 meters have some sandy beds rich in glass and zeolites. Grains of glass, zeolite, and palagonite are moderately common throughout the Cretaceous beds, and some bluish green volcanic laminae are present in the basal meter of sediment in Core 94.

The basement contact is at 1168 meters, within Core 94 . The drill penetrated a relatively coarse-grained basalt or fine-grained diabase. The rock is from either the interior of a flow or a shallow intrusive. Near the top it contains a few large plagioclase crystals with groundmass inclusions (xenocrysts?), but it is otherwise essentially aphyric. A breccia zone within it is probably of tectonic origin. The breccia contains clasts of green and red chert.

The base of Core 94 penetrated a breccia which is in part hyaloclastic. It may be an interflow breccia (the underlying basalt is distinctly different in composition from, and finer-grained than, that above), a tectonic breccia, or both.

Core 95, at its top, penetrated at least two pillows or flow units of fine-grained microphyric basalt with glassy selvages. These basalts contain several percent plagioclase xenocrysts(?) (Plate 2, Figure 6) which are more numerous than, but not so large as, those in the basalt of Core 94 . In the middle of Section 2, Core 95 penetrated a basalt breccia, not hyaloclastic, which is probably of tectonic origin. The basalt clasts are fine-grained, as in Section 1, and the largest clast contains a few plagioclase grains interpreted as xenocrysts.

In the lower part of Section 2 and in the core catcher, Core 95 recovered breccias and fine-grained massive basalt. The breccias are composed mostly of fine-grained basalts similar to those higher in the core, but both these clasts and the massive basalt lack plagioclase xenocrysts. One breccia contains a minor but significant proportion of altered glass clasts, but is not a hyaloclastite as such. The absence of glass selvages on the clasts suggests that the lower part of the core penetrated the interior of a relatively thick pillow or flow unit, but not so deep in the interior as the much coarser basalts of Core 94 . The breccias are probably of tectonic origin.
The rocks are not clearly alkaline. They have a generally tholeiitic aspect except for the presence of clinopyroxene microphenocrysts and the almost or quite complete absence of identifiable olivine (pseudomorphs), even as microphenocrysts (a few microphenocrysts are found in the fine-grained basalt in 95-2, $40-43 \mathrm{~cm}$.) Both features might be explained by extensive crystal fractionation of an ocean ridge basalt, or by the rocks being ocean island tholeiites rather than ocean ridge basalts. Trace element chemistry (Figures 1,2, and 3) supports the interpretation that the rocks are fractionated ocean ridge basalts $(\mathrm{Fe} / \mathrm{Mg}$ is affected too much by $\mathrm{Mg}$ loss during alteration to be useful as a measure of such fractionation). However, the intense alteration, including destruction of clinopyroxene, may have led to loss of trace elements and a reduction of apparent "alkalinity". If so, the original rocks may have been ocean island tholeiites or even mildly alkaline basalts which would be more consistent with their presence in the volcanic edifice represented by Magellan Rise.

The opaque grains are moderately titaniferous titanomagnetite without ilmenite and with no evidence, in the case analyzed in detail, for diagenetic oxidation to maghemite and anatase. The magma at the time of eruption appears, therefore, to have been moderately oxidized, but not so much so that the assemblage ilmenite plus Ti-poor titanomagnetite formed as at Hole 165 A, Site 170, and possibly Site 171 (see Appendix A and Table 3 ).

The rocks are notably non-vesicular and contain few or no readily identified amygdules. The magmas were probably water-poor and crystallized under high pressures. Nonetheless, there are abundant ovoid to irregular masses of montmorillonite (Plate 2, Figures 3,7 , and 8 ) which are similar to amygdules in many ways, as well as large ovoids of calcite, with or without montmorillonite, which are too large to be amygdules. Both these features are tentatively explained as alteration products of chlorophaeite (so-called fibro-chlorophaeite). Similar masses are even more abundant at Site 171.

Alteration is intense and varied. The cores of plagioclase xenocrysts(?) are altered almost completely to monoclinic $\mathrm{K}$-feldspar and montmorillonite (Plate 2, Figure 6). In association with the abundant secondary calcite, the K-feldspar has the same association as authigenic feldspar in limestone.

Primary plagioclase is slightly replaced by montmorillonite but is, for the most part, fresh. Pyroxene is moderately to extensively replaced by montmorillonite (Plate 2, Figures 4 and 5). In the upper part of the hole (Core 94 and the upper part of Core 95), glass and palagonite selvages, glass and palagonite clasts in breccias, interstitial glass, and the uncommon olivine microphenocrysts are wholly altered to montmorillonite plus trace amounts of calcite. Deeper in Core 95, the alteration products are montmorillonite plus progressively increasing proportions of celadonite. Opaque minerals are apparently unaltered.

Veins and the cements of breccias in the upper part of the basement are calcite and montmorillonite mixed in variable proportions. Deeper in the hole, the montmorillonite is accompanied by increasing proportions of celadonite.

The altered chlorophaeite(?) masses are mainly montmorillonite with little or no calcite, but a few large masses are dominantly to wholly calcite. Toward the bottom of the hole, celadonite also appears in these masses, for example in the green patch in Core 95-CC (Appendix A).

Oxidation does not appear to have been intense to judge from the survival of pyrite and the titanomagnetite. Only in a chert clast in a breccia (Core 94-CC) is pyrite oxidized to hematite. Either the free access of oxygen was limited to this breccia zone, which seems unlikely, or the chert was oxidized prior to incorporation into the breccia.

Of special note is the apparent steep gradient of conditions in the basement as evidenced by the notably greater amounts of celadonite at depth in the short section of basement penetrated in this hole. A similar apparent gradient was found at Site 166 .

These rocks are among the most altered igneous rocks recovered during Leg 17 . Only at Sites 170 and 171 were comparably altered rocks recovered. Several factors seem to determine this, and the same factors are repeated at Site 171. The abundance of K-feldspar is primarily controlled by the availability of a suitable substrate for replacement, namely, the highly calcic cores of large plagioclase xenocrysts(?) and phenocrysts. However, this alone does not always 
insure abundant K-feldspar, as witness Site 164 and the shallowest sample examined from this site $(94-2-137-140 \mathrm{~cm})$, where partial to complete survival of some cores is found. $\mathrm{K}$-feldspar formation must, therefore, be influenced by other factors.

The important factors which, alone or in consort, appear to favor alteration seem to be:

1) High $\mathrm{CO}_{2}$ activity, probably related to a carbonate-rich sediment section and to factor 2 (compare Site 171 and contrast Hole 165A); the K-feldspar may in part be related to this factor in the same manner as authigenic K-feldspar in limestone. Mafic minerals and femic glass seem especially to be subject to attack in a $\mathrm{CO}_{2}$-rich environment.

2) A high topographic position, facilitating ready circulation of seawater (compare Site 171 and contrast all other sites).

3) Coarse grain size, which may provide greater permeability large glassy patches (which, when altered, increase permeability still further); and more susceptible crystalline phases (higher degrees of crystallization may lead, for instance, to Fe-richer, more reactive pyroxenes). Compare Site 170 and contrast Sites 164 and 166; the relatively coarse grain sizes at Hole $165 \mathrm{~A}$ may be offset by the different nature of the crystalline phases, particulariy the hydrous ones, and the low $\mathrm{CO}_{2}$ activity .

4) The abundance of a very susceptible phase, tentatively identified as chlorophaeite, which now appears as the montmorillonite (+ calcite) ovoids and patches. The presence of this phase may be related to other chemical and mineralogic characteristics which render the rocks highly alterable. Comparable material may have been present to the same extent at only one other site (171), and there too the alteration is intense.

As a final note, the presence of mixed-layer chlorite-montmorillonite (Appendix A) suggests mildly elevated temperatures during alteration. In oceanic basalts examined by Bass, chlorite and mixed-layer chlorite-montmorillonite occur only in metamorphosed rocks or in those rocks sufficiently coarse-grained to suggest sills, dikes, or the interiors of thick flows, where cooling was slow enough to allow appreciable deuteric action. The present basalts are in part fairly coarse-grained; however, the mixed-layer phase is not found in them but in breccia zones cutting both them and the finer grained basalts. The suggested cause of elevated temperatures in this case is hydrothermal solutions related in origin either to the tectonism which produced the breccia zones, or to post-tectonic magmatism in Magellan Rise. The breccia zones evidently afforded conduits for the solutions (compare Site 171).

All factors considered, it appears that the igneous rocks from Site 167 are not oceanic crust proper, but parts of a volcanic edifice constructed some distance from the rise crest at which the underlying crust was formed. The edifice evidently did not reach sea level. There are probably older sediments at depth.

\section{Petrography}

17-167-94-2, 137-140 cm: Specimen consists of dark brownish gray, intergranular to intersertal, feldspathic diabase or coarsegrained basalt. A few large euhedral plagioclase xenocrysts(?) are present, but otherwise the rock is aphyric. It is highly altered and texturally complex. Abundant small, round to irregular patches consist of white calcite, dark green montmorillonite or a mixture of the two. Regardless, the montmorillonite in the patches is counted with the altered intersertal residuum in the mode, and the calcite separately. There is one calcite vein, about $0.1 \mathrm{~mm}$ wide, with an irregular trend.

\begin{tabular}{ccc}
\hline $\begin{array}{c}\text { Component } \\
(\min / \max \text { size }-\mathrm{mm})\end{array}$ & Average & Volume \\
$($ Size $(\mathrm{mm})$ & $(\%)$ \\
\hline
\end{tabular}

Plagioclase xenocrysts(? $)^{\mathrm{a}}$

$>(13 \times 7.5 \times 7) \max$

Plagioclase (non-phenocrystic)

$(0.1 \times 0.01 / 0.8 \times 0.15)$

$0.3 \times 0.06$

30.4

Pyroxene ${ }^{b}$

(small min)
Opaque grains

equant

$(0.08 \times 0.07 / 0.17 \times 0.21) \quad 0.1 \times 0.1$

skeletal

$(0.8 \times 0.15 \max )$

Intersertal montmorillonite

Calcite + montmorillonite patches

$(0.8 \times 0.65 / 1.25 \times 0.8)$

Amygdules $c$

$(1.1 \times 1.1 \max )$

Calcite free of montmorillonited

aThe cores are in part diagenetically replaced by minor K-feldspar and traces of montmorillonite and phillipsite (and perhaps a second zeolite). The plagioclase is An93 by X-ray peak separations and An80-9l by refractive indices of cleavage flakes (Appendix A). Apparently it is somewhat variable in composition.

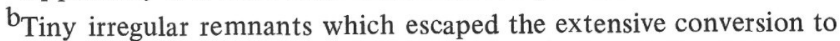
montmorillonite (compare Plate 2, Figures 4 and 5) which now comprises much of the "intersertal montmorillonite" (see component 5). Originally the pyroxene was texturally intergranular with respect to plagioclase.

cSee Figure 11.

dVarious modes of occurrence; only veins were excluded.

17-167-94-3, 31-35 cm: Specimen is a basalt cut by a breccia zone about $2.5 \mathrm{~cm}$ wide. The breccia has sharp, straight sides which are almost parallel, and is composed of fragments of chert, basalt and montmorillonite in a matrix of calcite and montmorillonite. The montmorillonite clasts are subangular and may be altered glass. An angular, wedge-shaped basalt fragment closely resembles the wall rocks.

Textural relations do not suggest an interpillow or interflow origin. The foreign (chert) clasts might suggest an open crevice filled by debris from above, but the largest chert clast extends from wall to wall and fits tightly against the walls continuously for more than $2 \mathrm{~cm}$; this clast is unlikely to have fallen so far. The breccia zone is probably of tectonic origin.

17-167-94-3, 78-84 cm: Specimen is a brownish gray, aphyric, nonvesicular diabase or coarse-grained basalt. The original intergranular to ophitic pyroxene is now largely altered to intersertal montmorillonite (Plate 2, Figures 4 and 5). No definite amygdules or pseudomorphs after olivine are present. The rock is probably from the interior of a thick flow or sill. It contains a sharply bounded $(2 \times 1) \mathrm{cm}$ ovoid composed of calcite masses embedded in light brownish gray montmorillonite (this montmorillonite plus that from the groundmass were separated for chemical analysis). No other similar masses of this size were observed in this, or most other, samples from this hole, so the ovoid is probably not a vesicle filling; it may be an altered mass of chlorophaeite. The calcite masses in the ovoid are of two types (Appendix A and Table 6): massive, white $\left(0.5\right.$ mole $\left.\% \mathrm{MgCO}_{3}\right)$ and dull dirty looking calcite which radiates from central areas that are dark with montmorillonite inclusions $\left(0.5\right.$ mole $\left.\% \mathrm{MgCO}_{3}\right)$. Clusters of pyrite euhedrons occur along the calcite-montmorillonite contacts in the ovoid.

\begin{tabular}{lcc}
\hline \multicolumn{1}{c}{$\begin{array}{c}\text { Component } \\
(\mathrm{min} / \mathrm{max} \text { size }-\mathrm{mm})\end{array}$} & $\begin{array}{c}\text { Average } \\
\text { Size }(\mathrm{mm})\end{array}$ & $\begin{array}{c}\text { Volume } \\
(\%)\end{array}$ \\
\hline $\begin{array}{l}\text { Plagioclase } \mathrm{a} \\
(0.07 \times 0.015 / 0.9 \times 0.2)\end{array}$ & $0.45 \times 0.12$ & 43.5 \\
$\begin{array}{l}\text { Pyroxene remnants } \\
(0.05 \times 0.03 / 0.55 \times 0.4)\end{array}$ & $0.15 \times 0.15$ & 14.0 \\
$\begin{array}{l}\text { Opaque grains } \mathrm{b} \\
(0.02 \times 0.03 / 0.4 \times 0.35)\end{array}$ & $0.3 \times 0.25$ & 3.2 \\
Montmorillonite $\mathrm{c}$ & & 39.3 \\
Calcite & & Trace \\
\hline
\end{tabular}


${ }^{a} \mathrm{An}_{53}$ to $\mathrm{An}_{67}$ from Carlsbad-albite twins.

bX-ray analysis (Appendix A) indicates moderately titaniferous titanomagnetite plus traces of anatase; no ilmenite was detected.

cLargely replaces pyroxene (Plate 2, Figures 4 and 5), but also plagioclase and probably primary mesostasis.

17-167-94-CC, (a and b): Sample 94-CC(a) is a collection of chips, most of which are breccia composed of basalt or fine-grained diabase fragments in a calcite cement. The basalt fragments are relatively coarse-grained, like the unbrecciated basalts above, but there are also clasts of much finer grained basalts (see petrographic description 94-CC [2]), like the underlying basalts (e.g., 95-1, 55 $\mathrm{cm}$ ) and montmorillonite clasts, which may be altered glass. The breccia is probably an interflow breccia, at least in part hyaloclastic, but perhaps in part tectonic.

The largest basalt fragment (94-CC $[\mathrm{b}]$ ) is not attached to any calcite matrix and looks like the main basalts or diabases above. It contains sparse augite microphenocrysts, and its plagioclase is replaced to a small extent by $\mathrm{K}$-feldspar. The opaque minerals are apparently magnetite, without ilmenite (Appendix A).

17-167-94-CC (1) This thin section was cut aboard the Glomar Challenger, apparently from a sample like 17-167-94-CC-(b). It is relatively coarse-grained intersertal basalt, composed of plagioclase (15 to 20\%), pyroxene remnants (3\%), and groundmass $(80 \%)$. Former mesostasis in the groundmass is marked by opaque grains (including a trace of pyrite), patches of tiny, secondary calcite(?) granules, and rare montmorillonite amygdules. The bulk of the groundmass is green montmorillonite, much of it formed by replacement of py roxene.

17-167-94-CC (2): The thin section was cut apparently from a calcite-cemented breccia sample like 94-CC(a) (see above). The clasts are coarse- and fine-grained basalt, and subangular to subrounded masses of green montmorillonite (altered glass).

The finer grained basalt clasts are crudely variolitic (plagioclase occurs in vague radial to subradial arrays), and richer in opaque minerals than the coarser grained basalts. Both types contain abundant patches of green montmorillonite which enclose numerous calcite(?) granules, and a smaller number of calcite patches rimmed by green montmorillonite.

One seam in the calcite cement contains quartz along its center; quartz is otherwise generally absent or very rare in the igneous rocks recovered during Leg 17. Rare rhombs of carbonate with high refractive indices (siderite?) occur in the calcite.

Several basalt clasts contain pyrite grains. One ovoid clast of green montmorillonite is more than $50 \%$ pyrite.

17-167-95-1, $55 \mathrm{~cm}$ : Sample is dark brown gray, fine-grained, porphyritic, intersertal basalt. Apparently, it is the top of a flow unit.

Phenocrysts (1\%) are mainly plagioclase and a trace of pyroxene. No definite pseudomorphs after olivine were identified. All but thin rims of the plagioclase are largely replaced by $\mathrm{K}$-feldspar and green montmorillonite (compare Plate 2, Figure 6).

The groundmass is composed of plagioclase $(15 \%)$, granular pyroxene $(2-3 \%)$ and opaque minerals $(8 \%)$ in a mass of intersertal montmorillonite (65-70\%) and feathery pyroxene. Some montmorillonite occurs as amygdules or altered chlorophaeite, and calcite $(2-3 \%)$ forms amoeboid patches, either alone or mixed with montmorillonite.

17-167-95-1, 89-91 cm: Sample is a dark brown gray basalt with altered glassy selvage; the altered glass has concentric color laminations outlining tiny blocks like those in palagonite. This fact suggests that the glass was palagonitized prior to diagenetic alteration.

The one plagioclase phenocryst observed is colorless, with an orange red core. The altered glass of this sample and the fine grain size of the overlying basalt sample suggest that at least the upper part of Core 95 penetrated a series of pillows or thin flow units.

17-167-95-2, 40-43 cm: This sample is a brown gray, finegrained porphyritic variolitic basalt.

\section{Component \\ $(\mathrm{min} / \mathrm{max}$ size $-\mathrm{mm})$}

Average

Size $(\mathrm{mm})$

Volume

Plagioclase xenocrysts(?)

$(0.6 \times 0.25 / 0.6 \times 2.5)$

Plagioclase microphenocrysts

$(0.09 \times 0.02 / 0.45 \times 0.4)$

$0.22 \times 0.04$

Pyroxene microphenocrysts

$(0.07 \times 0.06 / 0.28 \times 0.25)$

$0.17 \times 0.13$

Olivine microphenocrysts (pseudomorphs) $^{\mathrm{b}}$

$(0.07 \times 0.05 / 0.23 \times 0.15)$

$0.12 \times 0.1$

Groundmass plagioclase ${ }^{\mathrm{c}}$

$(0.02 \times(<<0.01) / 0.1 \times 0.01)$

$0.046 \times 0.004$

Variolitic pyroxene

(+ montmorillonite)

Opaque grains

equant $(0.04 \max )$

elongate $(0.04 \times 0.005 \max )$

Groundmass montmorillonite

Amygdules(?) or altered chlorophaeited

(very small $/ 6.5 \times 5$ )

aUsually all but a thin plagioclase rim is extensively to completely replaced by monoclinic $\mathrm{K}$-feldspar and montmorillonite (Plate 2, Figure 6); in some cases the core survives and an intermediate zone is replaced by montmorillonite; or the core is dissolved out, leaving a hole surrounded by the plagioclase rim.

bWholly altered to greenish brown montmorillonite.

${ }^{c}$ Components of feathery varioles.

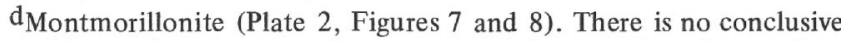
evidence that these patches are amygdules nor that they replace the host rock. They may be altered chlorophaeite.

17-167-95-2, 99-100 cm: Sample is basalt breccia with cavities. It is mainly brown-gray, with medium to dark green montmorillonite as cement between clasts and as flakes lining cavities, and with minor calcite patches; the dark green glakes include minor mixed-layer chlorite-montmorillonite (Appendix A). A portion of the breccia is medium to light green; the darker portions of this part are celadonite and montmorillonite. The basalt clasts are crystalline, not hyaloclastic, so apparently the breccia is not an interpillow filling. It may be a tectonic breccia zone along which heated solutions moved, as indicated by the mixed-layer chlorite-bearing phase and by the high degree of crystallinity of the montmorillonite. The largest basalt clast contains plagioclase xenocrysts(?).

17-167-95-2, 127-128 cm: Sample is brown gray breccia; the clasts are mostly basalt, but many small, angular to rounded, light green or dark green, massive ones may be altered glass. No plagioclase xenocrysts(?) were observed in the basalt clasts. X-ray analysis (Appendix A) of a dark green massive fragment indicates $1 \mathrm{M}$ celadonite plus traces of montmorillonite and calcite. Light green fragments are softer than the dark green, and tend to be rounder, but are otherwise similar. X-ray analysis of three light green fragments indicates montmorillonite, minor $1 \mathrm{M}$ or $1 \mathrm{Md}$ celadonite, and a trace of calcite. The cause of alteration primarily to celadonite, or primarily to montmorillonite, is not known (palagonite vs. sideromelane?).

The breccia has no remaining cavities. Some earlier pores were filled by white calcite, and one of these has a concentration of pyrite along its edge.

The breccia is not a hyaloclastite as such. It may be of tectonic origin.

17-167-95-CC: There are two samples: (a) brown gray basalt breccia with few or no altered glass clasts and no plagioclase xenocrysts(?), and (b) Fine-grained brown gray basalt; like otherwise similar looking basalts higher in Core 95 except that it 
contains no megascopically visible plagioclase phenocrysts or xenocrysts(?). It contains dark green celadonite plus montmorillonite patches which seem to grade out to the host basalt, and also accessory grains of pyrite.

\section{SITE 168}

Only 75 meters were drilled at this site. The pelagic brown clay is rich in zeolites and montmorillonite, which, with the palagonite, glass, and feldspar, indicate volcanic contributions to the sediment.

\section{SITE 169}

This site is a few $\mathrm{km}$ from Site 168 , and brown clays are the main sediment down to 193 meters depth. They contain porcellanitic chert beds, and at 181 to 188 meters a sill of diabase, described below. The petrologic affinities of the diabase are uncertain. The claystones immediately under the sill have laminae rich in feldspar and glass. The chalk between 193 and 219 meters shows no volcanic components, but the brown zeolitic clay between the chalk and the extrusive basalt at 225 meters is dominantly phillipsite and montmorillonite with some palagonite and glass. These components suggest that fragmented volcanic material, probably hyaloclastite, was reworked from the surfaces of adjacent flows, redeposited here, and diagenetically altered. The extrusive flows are probably wholly or in part pillowed.

The sill is mainly medium-grained, aphyric diabase, with chilled roof and base of fine-grained porphyritic diabase (or coarse-grained basalt) and a very thin glassy selvage (less than $1 \mathrm{~cm}$ thick) at the base and probably at the top. Phenocrysts indicate that the liquidus phases were plagioclase and olivine. These continued crystallizing into the groundmass where they were joined by pyroxene, Ti-rich titanomagnetite, and accessory amounts of brown hornblende and possibly biotite. The magma was richer in water than most oceanic tholeiites, and a late build-up of water content led, not only to primary hydrous phases, but to a complex assortment of minerals, most of them hydrous, which crystallized from water-rich, late magmatic and deuteric fluids. The minerals include acicular, green to colorless amphibole (Plate 3, Figures 7 and 8; Plate 4, Figure 1), brown to green biotite(?), apatite (Plate 3, Figure 4), chlorite, montmorillonite, mixed-layer chlorite-montmorillonite, phillipsite (Plate 3, Figures 2 and 3), and possibly traces of calcite and pyrite. These minerals are texturally interstitial. The optic angles of phillipsite change progressively downward from large positive, to small positive or negative, to large negative, and suggest progressive changes of composition, structural state, or both. The late hydrous fluids also gave rise to secondary hydrous minerals which replaced primary phases. Most important among these are phillipsite, traces of chabazite after plagioclase (Plate 3, Figure 5), and brown montmorillonite plus minor chlorite (and possibly mixed-layer chlorite-montmorillonite) after olivine (Plate 3, Figure 6). Traces of green to colorless amphibole may have replaced some pyroxene at this stage. The montmorillonite may in part be diagenetic, but other relations, discussed below, suggest that the interior of the sill is little affected by diagenesis. The survival of fresh pyrite indicates that deuteric alteration and diagenesis, if any, in the interior of the sill occurred under nonoxidizing conditions.

The mineralogy at, and immediately above, the lower contact indicates absorption of water from the underlying sediments. Therefore, although the residual magma was ultimately enriched in water, the initial magma was undersaturated. The lower glassy selvage is almost free of primary and deuteric hydrous minerals (those present include traces of pyrite, mica, chabazite, and calcite; the abundant montmorillonite is probably diagenetic), whereas, immediately above this selvage there are abundant amphibole, chlorite, and montmorillonite, plus minor calcite and traces of mixed-layer chlorite-montmorillonite. These minerals increase to a maximum about $1 \mathrm{~cm}$ above the glassy selvage and are measurably less abundant $3 \mathrm{~cm}$ above the selvage. The selvage evidently chilled too fast to crystallize hydrous phases. Immediately above, however, the slower rates of chilling and the advent of water allowed their abundant development. Still higher, the water was absorbed by, and mixed with, the slowly crystallizing and probably convecting interior bulk of the magma and did not influence mineral, composition until the late magmatic and deuteric stages. The only suggestion of absorption of water at the top contact is a high concentration of chlorite in the upper, finer-grained part of the topmost sample (17-169-5-1, 21-24 cm), so high a concentration, in fact, that it causes a notable maximum in the $\mathrm{MgO}$ concentration in the sill as a function of depth (see Table 1). Evidently the high concentration of water at the roof caused a selective precipitation of chlorite components from the convecting magma. Additional evidence for the absorption of water at the upper contact of a sill is provided by the igneous rocks cored at Site 170 .

The base contains almost pure magnetite in addition to, or instead of, Ti-rich titanomagnetite. The magnetite may be a diagenetic oxidation product of the titanomagnetite, but it is regarded as more likely to be a primary phase controlled by a high partial pressure of oxygen related to the high water content.

Veins are sparse in the sill. Most are composed of serpentine, chlorite, and minor amounts of montmorillonite and/or mixed-layer chlorite-montmorillonite. The vein serpentine is the only serpentine found in any of the Leg 17 rocks. In the lower part of the sill, there is a vein composed of natrolite, chlorite, minor montmorillonite (and/or mixed-layer chlorite-montmorillonite), and a trace of calcite; the dark, fine-grained, altered diabase adjacent to the vein is rich in montmorillonite and contains scattered grains of pyrite. The veins were probably deposited during the deuteric stage.

The last even recorded in the sill is diagenetic alteration. Near the top contact, this led to replacement of the calcic cores of plagioclase phenocrysts by monoclinic K-feldspar (Plate 2, Figure 1), oxidation of opaque minerals (magnetite or Ti-rich titanomagnetite?) to maghemite plus anatase, and the replacement of remnant olivine, and perhaps late residuum (if any was present), by montmorillonite. The glassy selvage at the base was altered to montmorillonite. The interior of the sill, which appears to have been mechanically intact and impermeable, may largely have escaped diagenetic alteration. The main mineral which may be, at least in part, of diagenetic origin in the interior is brown montmorillonite which replaced olivine (Plate 3, Figure 6), and perhaps interstitial montmorillonite. However, the brown montmorillonite is different from the diagenetic pseudomorphs after olivine near the top contact, and it increases in abundance near phillipsite-rich patches and deuteric veins; these facts suggest that the brown montmorillonite is of deuteric origin. Calcite is very scarce in the interior of the sill. The $\mathrm{CO}_{2}$ in that calcite may have been absorbed from the sediments during intrusion and the calcite then precipitated much later during the deuteric stage. It does not appear to be diagenetic. At the base of the sill, on the other hand, abundant calcite pseudomorphs after olivine and pyroxene (Plate 4, Figures 2, 3, and 4) are closely associated with diagenetic K-feldspar and with calcite which replace the cores of plagioclase microphenocrysts, and all of this calcite is believed to be diagenetic.

The basement at this site underlies Lower Albian sediments, and the sill intrudes Cenomanian or Turonian sediments. A K-feldspar concentrate from 17-169-5-1, 21-24 cm gives a K-Ar age of $58 \pm 2$ m.y. $\left(1.01\right.$ and $0.975 \% \mathrm{~K}$ in duplicate analyses; $2.33 \times 10^{-6} \mathrm{cc}$ $\mathrm{STP} / \mathrm{gram}{ }^{40} \mathrm{Ar}^{*} ; 73 \%$ atmospheric Ar correction; R. L. Armstrong, analyst). This is an integrated average age for the time of diagenesis, and places a younger limit on the age of the sill, which is probably of Late Cretaceous age. The sill was not directly related to a known spreading center at the time of emplacement. From a trace element standpoint, the rock is a trace-element-poor tholeiite (Table 1) like those erupted at the crests of spreading oceanic ridges. However, the major element chemistry is at variance with this interpretation. $\mathrm{Na}$ values are high and $\mathrm{Si}$ values low, resulting in considerable $\mathrm{NE}$ in the norm (Table 2). The rocks are too fresh and impermeable to account for the high $\mathrm{Na}$ by absorption of seawater during and after coring. It may be due to absorption of $\mathrm{NaCl}$ along with seawater during the magmatic stage. Alternatively, the chemical peculiarities may be due to extensive redistribution of late $\mathrm{SiO}_{2}$-rich fluids or intense autometasomatism during the deuteric stage in such a manner that the cored portion of the sill is enriched in $\mathrm{Na}$ and impoverished in Si. If such is the cause of undersaturation and it is of common occurrence in oceanic tholeiites, then considerable caution must be exercised in interpreting coarse-grained, critically undersaturated oceanic rocks, especially where the mineralogy is not diagnostic of an alkaline magma. In such cases it will be necessary to 
igneous phillipsite. They were probably erupted at the spreading center at which this region of the Pacific crust was generated. Contrary to the rocks currently erupted at the crest of the East confirm the interpretation with supporting evidence, such as the relative and absolute concentrations of refractory trace elements, like the rare earths, $\mathrm{Zr}$ and $\mathrm{Nb}$, the concentration levels of which may not be sensitively affected by late magmatic and post-magmatic processes.

Another alternative is that the magma was truly alkaline and rich in trace elements, but these were concentrated in late hydrous fluids which were lost from the sill (for which there is no direct evidence in the available specimens), or the fluids were collected in a portion of the sill other than that cored. Although this interpretation is, at first glance, less likely than those discussed above, it can help explain certain mineralogic peculiarities of the sill. Ocean ridge tholeiites usually contain olivine microphenocrysts in the composition range $\mathrm{F}_{082}$ to $\mathrm{Fo}_{87}$, and olivine does not continue to crystallize into the groundmass and shows no reaction relation with the magma. In the sill, the olivine is Fe-rich (Fo70; see Appendix A) and crystallized through most of the consolidation of the magma. The Fe-rich compositions may have resulted from continuous equilibration during the slow crystallization of this fairly coarsely crystalline rock. Lack of a reaction relation might indicate that the magma was not highly fractionated, a conclusion which would be consistent with the low trace element concentrations. However, the lack of a reaction relation may be a real reflection of the bulk chemistry and the presence of NE in the norm. This interpretation would mean that the present condition of undersaturation does not stem from the movements or autometasomatic effects of late fluids but was an intrinsic property of the magma relatively early in the history of crystallization of the sill, perhaps, even at the outset. The late fluids of a water-rich tholeiite should be $\mathrm{SiO}_{2}$-rich, and neither the movement of those fluids nor their reactions with earlier solid phases should render either them or the solid phases critically undersaturated. Yet, the deuteric minerals in the sill, specifically phillipsite, and perhaps chlorite, suggest that the late fluids were not $\mathrm{SiO}_{2}$-rich, but subsilicic. Diagenetic phillipsite is sparse to absent in quartz-bearing marine sediments and igneous rocks (mainly tuffs), and its presence in an oceanic sill may similarly reflect a truly subsilicic system. In this instance the phillipsite would be consistent with the low $\mathrm{SiO}_{2}$ in the bulk composition of the sill.

If the alkaline traits of the sill magma were due to early absorption of $\mathrm{NaCl}$ from seawater (and perhaps loss of $\mathrm{Si}$ to seawater by some unknown mechanism), we might expect a high $\mathrm{Cl}$ content in the sill and even Cl-bearing feldspathoids. But the $\mathrm{Cl}$ content is low (Table 1) and feldspathoids were not identified. Perhaps the magma, regardless of its initial chemistry, assimilated so much of the phillipsite-rich sediment between 219 and 225 meters depth, that its composition was radically altered. The assimilation hypothesis is not regarded as likely because of heat budget problems and the possible effects of sediment assimilation on trace element concentrations. The absence of recognizable xenoliths and chemical or mineralogical heterogeneities in the sill would demand significant superheat in the magma, but the chilled, porphyritic contacts argue against superheat. We must then entertain the hypothesis that the magma arrived from the mantle with alkaline bulk chemistry and either was initially low in trace elements or lost them after emplacement. It is this possibility that governs some of the speculations at the beginning of this chapter on igneous rocks, particularly those regarding isotope chemistry.

The basement basalts penetrated at Site 169 are a series of pillows, thin flow units, or both. Secondary calcite is more abundant than in the interior of the sill but not so abundant as in other holes drilled on Leg 17 (compare Sites 167 and 171). This paucity may be related to a relatively carbonate-poor sediment section. The rocks are fairly fresh (minor sideromelane survives), which may be a consequence of fine grain size and low $\mathrm{CO}_{2}$ activity (compare Sites 164 and 166). Minor celadonite is found throughout the section penetrated and may increase in abundance downward Secondary K-feldspar is sparse to absent. Augite crystallized fairly early, even among the few phenocrysts present. This fact suggests a fractionated ocean ridge basaltic magma, but not so fractionated that the concentrations of trace elements are notably increased. In fact, the rocks are chemically trace-element-poor ocean ridge basalts, and share the poverty in trace elements with the chemically unrelated overlying sill. Contrary to the sill, however, these flows and pillows contain much higher $\mathrm{SiO}_{2}$, no $\mathrm{NE}$ in the norm, and no Pacific Rise, however, the basement rocks at Site 169 are devoid of or notably poor in, normative HY (compare the norms in Table 2 with those of the EPR rocks reported in Bass, 1971). We might thus infer that the Site 169 basement rocks are not typical ocean ridge basalts, but transitional basalts with mildly alkaline affinities. This interpretation would explain the early augite without resort to fractionation and would help account for the slight negative slope of the light end of the REE rattern of 17-169-12-1, 31-32 cm (see Figure 4 and the discussion in the section "Original Rock and Magma Types"). However, as with the overlying sill, this interpretation would leave the low trace element contents unexplained. Carrying the argument one step further, we may entertain the possibility that the rocks are not ocean ridge basalts at all, in which case we would necessarily question whether they represent true basement.

\section{Petrography}

17-169-5-1, 21-24 cm: Sample consists of gray, porphyritic, fine-grained intergranular diabase (or coarse-grained basalt). It is not the chilled contact of the sill, but very near it to judge from the fine grain size and the gradation of grain size across the thin section.

\begin{tabular}{|c|c|c|}
\hline $\begin{array}{c}\text { Component } \\
(\mathrm{min} / \mathrm{max} \text { size }-\mathrm{mm})\end{array}$ & $\begin{array}{l}\text { Average } \\
\text { Size (mm) }\end{array}$ & $\begin{array}{l}\text { Volume } \\
(\%)\end{array}$ \\
\hline $\begin{array}{l}\text { Plagioclase phenocrysts (fresh } \\
\text { remnants) }^{\mathrm{a}} \\
(0.25 \times 0.08 / 2.4 \times 0.40)\end{array}$ & $1.10 \times 0.16$ & 4.25 \\
\hline $\begin{array}{l}\text { K-feldspar replacing plagioclase } \\
\text { phenocrysts }\end{array}$ & & 9.82 \\
\hline $\begin{array}{l}\text { Groundmass plagioclase } \mathrm{b} \\
\text { (fresh remnants) } \\
\text { finer end of section }(0.04 \times 0.006 / \\
0.15 \times 0.04) \\
\text { coarser end of section } \\
(0.11 \times 0.025 / 0.42 \times 0.06)\end{array}$ & & 17.16 \\
\hline $\begin{array}{l}\text { K-feldspar(?) (and phillipsite?) } \\
\quad \text { replacing groundmass plagioclase }\end{array}$ & & 2.05 \\
\hline $\begin{array}{l}\text { Pyroxene } \\
\text { finer end of section } \\
(0.03 \times 0.025 / 0.43 \times 0.22) \\
\text { coarser end of section }\end{array}$ & $\begin{array}{l}0.05 \times 0.05 \\
0.15 \times 0.15\end{array}$ & 16.36 \\
\hline $\begin{array}{l}\text { Olivine phenocrysts }{ }^{\mathrm{c}} \text { (Pseudomorphs) } \\
(0.4 \times 0.22 / 1.0 \times 0.75)\end{array}$ & $0.7 \times 0.5$ & 1.83 \\
\hline $\begin{array}{l}\text { Opaque grains in groundmass } \mathrm{d} \\
(0.02 \times 0.02 / 0.23 \times 0.08)\end{array}$ & $0.09 \times 0.08$ & 6.24 \\
\hline Opaque lens & $1.55 \times 0.15$ & 0.09 \\
\hline $\begin{array}{l}\text { Opaque inclusions in olivine } \\
(0.02 \times 0.02 / 0.15 \times 0.06)\end{array}$ & & Trace \\
\hline Apatite & & Trace \\
\hline $\begin{array}{l}\text { Phillipsite } \\
\text { patches }(0.3 \times 0.35 / 0.7 \times 0.6) \\
\text { individual crystals }(0.09 \times 0.05 / \\
0.45 \times 0.25)\end{array}$ & & 0.12 \\
\hline Red brown intersertal mass ${ }^{\mathrm{e}}$ & & 19.11 \\
\hline Chlorite $^{\mathrm{f}}$ & & 22.97 \\
\hline $\begin{array}{l}\text { Calcite patches } \\
(0.1 \times 0.03 / 0.5 \times 0.4)\end{array}$ & & 0.03 \\
\hline Golden yellow patches $\mathrm{g}$ & & Trace \\
\hline
\end{tabular}

${ }^{\mathrm{a}}$ The cores of plagioclase are completely altered to monoclinic $\mathrm{K}$-feldspar plus minor montmorillonite(?), probably of diagenetic origin (Plate 3, Figure 1). The K-feldspar contains patches and streaks of green or red brown clay or chlorite of uncertain origin. 
${ }^{b}$ The cores of the larger plagioclases are altered to a secondary material which appears to be K-feldspar, but much of which may be phillipsite.

${ }^{c}$ Wholly altered to a mixture of a deep red, very fine-grained, weakly birefringent, non-pleochroic mineral (white in reflected light), and bright green to yellow pleochroic chlorite; the chlorite may replace an early book-like mineral, perhaps iddingsite. The pseudomorphs are distinguished from similar interstitial material (component 12) by relic cracks lined by cross-fiber flaky minerals, by opaque inclusions, and by abundant spheroids of translucent red $\mathrm{Fe}$ oxide.

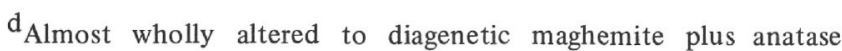
(Appendix A; see discussion of 17-170-16-1, 24-37 cm for comment on this maghemite.)

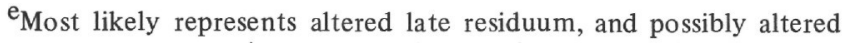
pyroxene to a minor extent; it may be composed of chlorite, montmorillonite, or both. Relative to the green chlorite (Component 13), the red brown material increases from the finer toward the coarser end of the section, but is unlike the brown flaky minerals in specimens from still deeper in sill.

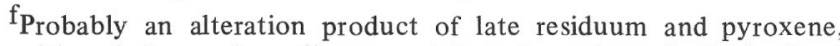
although it may be a direct precipitate from deuteric fluids. Bass' experience with oceanic basalts indicates that chlorite is found only in metabasalts and in deuterically altered intrusions and interiors of thick flows. The likely cause of its abundance near the top contact is, as suggested above in the general discussion, absorption of water from the sediments during primary cooling and crystallization.

$\mathrm{g}_{\text {May be pyroxene altered and oxidized to montmorillonite. }}$

17-169-5-1, 122-124 cm: Specimen is medium-gray, fine-grained aphyric diabase, intergranular to subophitic.

\begin{tabular}{lcc}
\hline \multicolumn{1}{c}{\begin{tabular}{c}
\multicolumn{1}{c}{$\begin{array}{c}\text { Component } \\
(\mathrm{min} / \mathrm{max} \text { size }-\mathrm{mm})\end{array}$} \\
$\begin{array}{l}\text { Average } \\
\text { Size }(\mathrm{mm})\end{array}$
\end{tabular}} & $\begin{array}{c}\text { Volume } \\
(\%)\end{array}$ \\
\hline $\begin{array}{l}\text { Plagioclase }^{\mathrm{a}} \\
(0.12 \times 0.03 / 2.6 \times 1.1)\end{array}$ & $1.0 \times 0.27$ & 51.5 \\
$\begin{array}{l}\text { Pyroxene } \\
(0.35 / 3.1 \times 0.9)\end{array}$ & 0.9 & 25.0 \\
$\begin{array}{l}\text { Olivine (fresh and altered })^{\mathrm{b}} \\
(0.2 \times 0.16 / 1.6 \times 0.9)\end{array}$ & $0.7 \times 0.55$ & 12.0 \\
$\begin{array}{l}\text { Opaque grains } \\
(0.12 \times 0.1 / 0.5 \times 0.23)\end{array}$ & $0.21 \times 0.2$ & 2.5 \\
$\begin{array}{l}\text { Montmorillonite and chlorite } \\
\text { Phillipsite }\end{array}$ & & \\
Calcite (interstitial) & & 8.6 \\
$(0.4$ max $)$ & & 0.1 \\
\hline
\end{tabular}

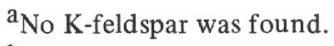

${ }^{\mathrm{b}} \mathrm{Granular}$ to intergranular; minor fresh remnants survive; mostly altered to brown montmorillonite and minor blue green chlorite(?).

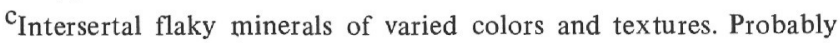
they are mostly a deuterically altered intersertal residuum or direct precipitates from deuteric fluids.

$\mathrm{d}_{\text {Interstitial aggregates, in some cases associated with intersertal }}$ chlorite and montmorillonite.

17-169-6-1, 63-70 cm: This specimen contains a horizontal, bluish gray, soft, sectile vein composed of chlorite (Mg-rich), serpentine, and minor mixed-layer chlorite-montmorillonite. Light brown olivine has a composition, estimated from $\mathrm{d}_{(130)}$, of Fo70 (Appendix A). A joint contains discontinuous, irregular lenses or patches of calcite; the rock on either side is dark and altered. Calcite in this mode of occurrence is rare in the sill.
17-169-2, 19-20 cm: Specimen consist of gray, medium-grained, aphyric, subophitic diabase. There are no veins and it is deuterically altered. Otherwise it is fairly fresh.

\begin{tabular}{|c|c|c|c|}
\hline \multirow[b]{2}{*}{$\begin{array}{c}\text { Component } \\
(\min / \mathrm{max} \text { size }-\mathrm{mm})\end{array}$} & \multirow[b]{2}{*}{$\begin{array}{l}\text { Average } \\
\text { Size }(\mathrm{mm})\end{array}$} & \multicolumn{2}{|c|}{ Volume $(\%)$} \\
\hline & & Diabase & $\begin{array}{l}\text { Zeolite- } \\
\text { Rich Area }\end{array}$ \\
\hline $\begin{array}{l}\text { Plagioclase (fresh remnants) } \\
(0.12 \times 0.05 / 1.7 \times 0.6)\end{array}$ & $1.2 \times 0.2$ & 41.0 & 9.8 \\
\hline $\begin{array}{l}\text { Pyroxene }{ }^{b} \\
(0.4 \times 0.35 / 3.1 \times 1.1)\end{array}$ & $2.0 \times 1.7$ & 28.8 & 16.3 \\
\hline $\begin{array}{l}\text { Olivine (fresh and altered })^{\mathrm{C}} \\
(0.2 \times 0.09 / 2.0 \times 1.5)\end{array}$ & $1.3 \times 0.5$ & 10.2 & 7.7 \\
\hline Chlorite and Montmorillonite ${ }^{\mathrm{d}}$ & & 5.7 & 9.6 \\
\hline $\begin{array}{l}\text { Opaque grains } \\
(0.02 \times 0.02 / 0.6 \times 0.6)\end{array}$ & $0.3 \times 0.3$ & 4.2 & 2.3 \\
\hline $\begin{array}{l}\text { Interstitial phillipsite } \\
(1.9 \text { (length)) }\end{array}$ & & 1.0 & 12.9 \\
\hline $\begin{array}{l}\text { Phillipsite replacing } \\
\text { plagioclase }^{\mathrm{f}}\end{array}$ & & 7.9 & 40.7 \\
\hline $\begin{array}{l}\text { Apatite }^{g} \\
(0.22 \times 0.16 / 0.8 \times 0.7)\end{array}$ & & & 0.2 \\
\hline $\operatorname{Mica}(?)^{\mathrm{h}}$ & & 0.3 & 0.5 \\
\hline Pyrite $^{\mathrm{i}}$ & & Trace & Trace \\
\hline
\end{tabular}

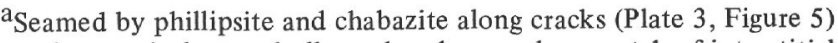
and extensively to wholly replaced near a large patch of interstitial phillipsite.

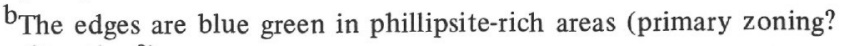
alteration?).

${ }^{\mathrm{c}}$ Granular to intergranular. Minor fresh remnants increase in a general way away from zeolite-rich areas. It is altered mainly to brown montmorillonite which is commonly surrounded by blue green rims, especially in phillipsite-rich areas. Contains rare opaque inclusions. $d_{(130)}$ indicates Fo71 (Appendix A).

$\mathrm{d}_{\text {Mainly brown montmorillonite which is most abundant near }}$ zeolite-rich areas. Notably, the montmorillonite and chlorite do not form clearly defined interstitial patches; phillipsite, accompanied by much montmorillonite and chlorite, assumes this textural role.

e Phillipsite-rich areas contain much brown and green montmorillonite and chlorite, and rare pyrite cubes (see Plate 3, Figures 2 and 3).

$\mathrm{f}_{\text {Accompanied by much green and brown montmorillonite and }}$ chlorite. Away from phillipsite-rich areas the flaky minerals decrease and the phillipsite gives way to phillipsite + chabazite seams along cracks (Plate 3, Figure 5).

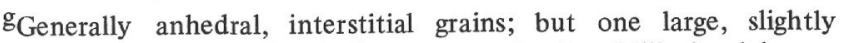
embayed, hexagonal euhedron occurs in the phillipsite-rich area (Plate 3, Figure 4).

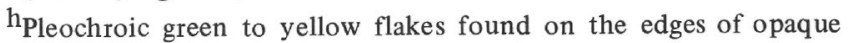
grains, in phillipsite-rich areas, and, rarely, around or in pseudomorphs after olivine. If the flakes are not themselves mica, they may have replaced mica because they contain rare remnants of brown biotite.

${ }^{\mathrm{i}}$ Rare grains in phillipsite-rich areas and in the main diabase. Their survival indicates that deuteric and diagenetic oxidation cannot have been intense in the interior of the sill, in contrast to the intense diagenetic oxidation at the top contact of the sill.

17-169-6-2, 37-39 cm: This specimen contains a horizontal vein composed of serpentine, chlorite (not so $\mathrm{Mg}$-rich as in the vein in 6-1, 63-70 cm), minor montmorillonite, and minor mixed-layer chlorite-montmorillonite (Appendix A). 
$17-169-6-3,33-38 \mathrm{~cm}$ : This sample is dark gray, medium- to coarse-grained, ophitic to intergranular olivine diabase. One very thin calcite vein $\left(2.5\right.$ mole $\left.\% \mathrm{MgCO}_{3}\right)$, with dark green selvages, occurs along an irregular joint. This sample contains the freshest olivine of any sample from the sill. Alteration of the olivine increases toward the calcite vein.

\begin{tabular}{|c|c|c|}
\hline $\begin{array}{c}\text { Component } \\
(\mathrm{min} / \mathrm{max} \text { size }-\mathrm{mm})\end{array}$ & $\begin{array}{l}\text { Average } \\
\text { Size }(\mathrm{mm})\end{array}$ & $\begin{array}{l}\text { Volume } \\
(\%)\end{array}$ \\
\hline $\begin{array}{l}\text { Plagioclase }^{\mathrm{a}} \\
(0.13 \times 0.08 / 1.92 \times 0.91)\end{array}$ & $1.18 \times 0.22$ & 51.02 \\
\hline $\begin{array}{l}\text { Pyroxene }{ }^{b} \\
(8.15 \times 4.45 \max )\end{array}$ & & 24.78 \\
\hline $\begin{array}{l}\text { Olivine (fresh) } \\
(0.21 \times 0.15 / 2.04 \times 1.66)\end{array}$ & $0.45 \times 0.30$ & 5.19 \\
\hline $\begin{array}{l}\text { Brown deuteric morillonite } \\
\text { replacing olivine }\end{array}$ & & 4.97 \\
\hline $\begin{array}{l}\text { Titanomagnetite } \\
(0.01 \times 0.005 / 0.7 \times 0.65)\end{array}$ & $0.32 \times 0.26$ & 3.15 \\
\hline Amphibole ${ }^{\mathrm{e}}$ & & 0.21 \\
\hline Interstitial chlorite ${ }^{\mathrm{f}}$ & & 6.25 \\
\hline Interstitial phillipsite & & 1.46 \\
\hline $\begin{array}{l}\text { Apatiteg } \\
\text { in plagioclase }(0.15 \times 0.005) \\
\text { in phillipsite }(0.66 \times 0.02)\end{array}$ & & 0.09 \\
\hline Biotite $(?)^{\mathrm{h}}$ & & 0.06 \\
\hline Zeolites in plagioclase & & 0.36 \\
\hline Late green montmorillonite $(?)^{\mathrm{i}}$ & & 2.40 \\
\hline Late brown montmorillonite(? $)^{\mathrm{j}}$ & & 0.03 \\
\hline Calcite $\mathrm{k}^{\mathrm{k}}$ & & 0.03 \\
\hline
\end{tabular}

${ }^{a}$ Almost wholly fresh. It is not notably more altered adjacent to interstitial phillipsite patches than elsewhere.

${ }^{b}$ Optically continuous over large areas. Fresh except possibly for late, peripheral, deuteric alteration to amphibole; near amphibole it is notably green. Opaque inclusions occur in the outer parts of grains, but not in their cores (Plate 3, Figure 7).

${ }^{\mathrm{c}}$ See Plate 2, Figure 6.

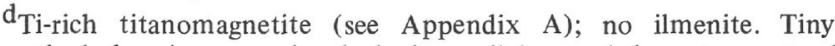
euhedral grains occur in plagioclase, olivine, and the outer parts of pyroxene; somewhat larger grains occur in interstitial chlorite. Apparently, most of the titanomagnetite crystallized late, and the composition indicates nonoxidizing conditions in the magma and an absence of secondary (i.e., diagenetic) oxidation effects. One anhedral opaque lens was observed in a crack in olivine; it may be a late, secondary opaque mineral.

${ }^{\mathrm{e}}$ Solid brown grading to acicular light green amphibole (Plate 3, Figure 8). The amphibole generally occurs on the edges of, or on rare occasions, inside of, pyroxene (Plate 3, Figure 7), in which case the immediately adjacent pyroxene tends to have a strong greenish tinge. It is also associated with interstitial phillipsite and chlorite and probably crystallized earlier than they to judge from the euhedral habit it may show when embedded in them (Plate 3, Figure 8; Plate 4, Figure 1). It is probably mostly a product of primary crystallization, both late magmatic and deuteric; and to a lesser extent it is a deuteric secondary replacement of pyroxene. The paragenesis appears to be: brown amphibole; then light green to colorless amphibole essentially contemporaneous with blue green chlorite; and finally phillipsite and light green chlorite (or montmorillonite).

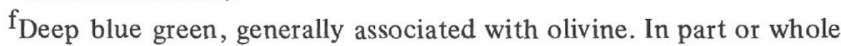
it may be equivalent to or grade to the late green "montmorillonite" (component 12). $\mathrm{g}_{\text {Tiny }}$ prisms in plagioclase, in phillipsite and in the green montmorillonite (or chlorite) associated with phillipsite.

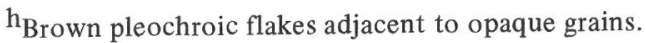

${ }^{i}$ Associated with, or enclosed by, late interstitial phillipsite; it also occurs as an alteration along cracks and cleavages in plagioclase. It is not especially associated with olivine, as is the deep blue green, interstitial chlorite (component 7), but they are gradational in most respects.

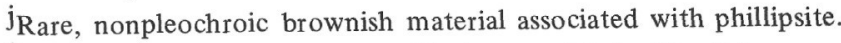

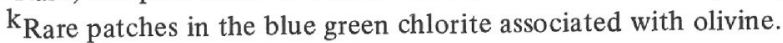

17-169-6-4, 88-92 cm: Specimen is gray, medium-grained olivine diabase; the main minerals by $\mathrm{X}$-ray analysis (Appendix A) are plagioclase, clinopyroxene, chlorite, and traces of chabazite, ilmenite (?-the identification of ilmenite anywhere in the sill is uncertain), and montmorillonite.

Olivine is moderately altered to slightly greenish brown "bowlingite" (montmorillonite), especially around its outer edges. Plagioclase is fresh except for minor phillipsite and chabazite along cracks. Interstitial phillipsite is rare. Tiny prisms of apatite are present in plagioclase and phillipsite.

A dense, white, discontinuous vein, which dips about $45^{\circ}$, is made of natrolite, chlorite, minor montmorillonite (or mixed-layer chlorite-montmorillonite), and a trace of calcite (Appendix A). The diabase next to the vein is dark, fine-grained, intensely altered, and sulfide-bearing. X-ray analysis of sulfide and host (Appendix A) indicates pyrite, montmorillonite, and traces of chlorite, calcite, and plagioclase. Both vein and wall rock have more calcite than is normally found in the sill, but the amount is still small.

17-169-6-4, 140-141 cm: Specimen consists of gray fine- to medium-grained diabase, richer in opaques and finer grained than most of the sill, and also more altered. Relatively little olivine survives the alteration to brown montmorillonite, and plagioclase is prominently altered to zeolites along numerous cracks. Interstitial zeolite is present, but there are no large patches. No K-feldspar is seen. X-ray data (Appendix A) indicate traces of montmorillonite and mixed-layer chlorite-montmorillonite in addition to large amounts of chlorite.

The opaque minerals are Ti-rich titanomagnetite, unaccompanied by anatase or ilmenite. The magma was evidently nonoxidizing, and the minerals have suffered little or no diagenetic oxidation.

This specimen was selected for isotopic and REE analyses (Tables 3 and 4 ; Figures 4 and 5 ) before it was realized that $17-169-6-3,33-38 \mathrm{~cm}$ is fresher.

17-169-6-5, 141-144 cm: Specimen is medium green gray, densely chilled porphyritic base of the sill. The contact dips about $45^{\circ}$, a fact which suggests an irregular, undulating contact molded during intrusion into soft, incompetent sediment.

About $3 \mathrm{~cm}$ above the contact, the rock is composed of plagioclase, K-feldspar, chlorite, clinopyroxene, and montmorillonite; minor amphibole and calcite; and traces of mixed-layer chlorite-montmorillonite and possibly ilmenite (see Appendix A). An early microphenocrystic plagioclase population is, except for very thin rims, altered to diagenetic $\mathrm{K}$-feldspar plus variable amounts of fine-grained calcite (Plate 4, Figures 2 and 3). Subhedral to euhedral pseudomorphs of fine-grained calcite, many of which are glomeratic with early plagioclase, are evidently alteration products of olivine and pyroxene microphenocrysts (Plate 4, Figures 2,3 , and 4). Smaller, later plagioclase laths are skeletal, with forked ends. The groundmass is mainly green chlorite and montmorillonite, in which are set remnants of very fine-grained, feathery pyroxene varioles. Most secondary calcite is notably fine-grained. No vesicles are present. Despite the high water content of the magma, as indicated by primary amphibole and possibly deuteric chlorite and montmorillonite, the high confining pressure prevented vesiculation and stabilized hydrous silicates. The opaque minerals comprise two distinct spinels: a Ti-rich titanomagnetite very similar to those higher in the sill, and one very near pure magnetite (see Appendix A). It is not known whether these spinels occur in different parts of the rock that are physically separated by some sharp or diffuse interface, or whether they are physically mixed. If separated, the 
interface may represent the limit to which abundant water diffused into the magma; below that limit it stabilized primary amphibole and buffered the oxygen fugacity at a value at which magnetite was stable (probably at a value between those of the quartz-magnetitefayalite and magnetite-wüstite buffers). The Ti-rich spinel would then have crystallized above the diffusion limit in the highly fluid, convecting, well-mixed body of magma where the partial pressure of water never attained high values in the early stages of crystallization. If this were the case, one expects that the magnetite might be accompanied by ilmenite or another chlorite, or a late mesostasis. If the two spinels are physically associated, the magnetite might be an oxidation product of the Ti-rich spinel, the oxidation failing to destroy all of the titanomagnetite. Diagenetic oxidation in other rocks recovered during Leg 17 produces, not magnetite, but maghemite plus anatase, both of which are absent here. Oxidation, therefore, if it occurred, was probably deuteric, or, if diagenetic, it occurred at a lower oxygen fugacity than that at the top contact of the sill during diagenesis.

About $1 \mathrm{~cm}$ above the contact, the rock looks like that at $3 \mathrm{~cm}$, and is composed of plagioclase, clinopyroxene, chlorite, montmorillonite, amphibole, and K-feldspar; minor calcite; and traces of mixed-layer chlorite-montmorillonite (see Appendix A; the opaque minerals were not isolated for special study and hence are not individually identified). The main difference from the rock $3 \mathrm{~cm}$ above the contact is the notably more abundant amphibole. This difference confirms that the increased water, which stabilized the amphibole, probably diffused in from the lower contact of the sill.

The contact itself is marked by a dark gray to black layer, about 3 to $4 \mathrm{~mm}$ thick, which was originally probably glassy. Two distinct rock types are present and in places are interlayered: (1) dense, dark gray, massive material composed of montmorillonite and plagioclase; minor clinopyroxene, $\mathrm{K}$-feldspar and pyrite(?); and traces of mica and calcite; and (2) dense, light gray, locally laminated or streaky (flow-banded?) material composed of montmorillonite, plagioclase, K-feldspar and clinopyroxene; minor amphibole, pyrite(?) and chlorite; and traces of calcite and chabazite. At the immediate contact is a large, very coarse-grained patch of calcite (recrystallized sediment?). The calcite encloses material, similar to type (1), which is composed of plagioclase, clinopyroxene, montmorillonite, minor calcite, and a trace of mica. The dark contact layer differs from the green gray 1 to $3 \mathrm{~cm}$ above mainly in the absence or markedly reduced abundance of amphibole, chlorite, and mixed-layer chlorite-montmorillonite, all of which appear to require water and elevated temperature for their formation. Montmorillonite, on the other hand, remains quite abundant. The high temperature hydrous phases could not have begun to crystallize until the sill was in process of emplacement and had absorbed water. By that time the glassy skin was so chilled and viscous that crystallization of hydrous phases was impeded, despite abundance of water, whereas the earlier crystallization of anhydrous phases like plagioclase and clinopyroxene before and during intrusion had not been similarly impeded in that skin. The montmorillonite probably formed by alteration of the glass and, like $\mathrm{K}$-feldspar, is of low-temperature diagenetic origin.

17-169-11-1, 84-85 cm: Specimen is medium gray basalt megascopically like 11-CC. It is cut by calcite veins with selvages of green celadonite and minor montmorillonite. Along projections of the veins they gave way to areas rich in irregularly distributed calcite patches. One such area includes an irregular dark green patch of celadonite ( $1 \mathrm{Md})$; otherwise green material is very minor in the calcite patches.

17-169-11-CC: Specimen is a medium gray, porphyritic and glomeroporphyritic basalt with a densely chilled groundmass. Isolated phenocrysts are very minor and glomerocrysts very abundant. The glomerocrysts, in fact, are really fairly large patches of a fine-grained, granular rock, and represent the products of a prolonged stage of relatively slow crystallization which was terminated by the final chilling which produced the groundmass (Plate 4, Figures 5 and 6). The rock may be tholeiitic (see the analyses of underlying basalts from Core 12 in Table 1), and perhaps fractionated to give the observed early crystallization of pyroxene.
The rock is cut by calcite veins $\left(1.0\right.$ mole $\left.\% \mathrm{MgCO}_{3}\right)$ which enclose minor gray montmorillonite(?) and have selvages of deep blue green celadonite. Pockets of deep blue green celadonite (1M; the best crystallized celadonite found in any Leg 17 igneous rock) may be amygdules, or altered, late, interstitial residuum, or possibly pseudomorphs after olivine phenocrysts (see footnote $b$ below). Besides celadonite, the pockets also contain traces of calcite and montmorillonite; the montmorillonite may correspond to light reddish brown material that was observed megascopically to be enclosed in the celadonite.

\begin{tabular}{ccc}
\hline Component & Average & Volume \\
$(\min / \max$ size $-\mathrm{mm})$ & Size $(\mathrm{mm})$ & $(\%)$ \\
\hline
\end{tabular}

Plagioclase phenocrysts ${ }^{\mathrm{a}}$

$(0.45 \times 0.07 / 1.7 \times 0.15)$

Olivine phenocrysts $\mathrm{b}$

(pseudomorphs)

$(0.4 \times 0.3 / 0.8 \times 0.3)$

Plagioclase microphenocrysts $\mathrm{c}$

$(0.08 \times 0.01 / 0.38 \times 0.35)$

$0.15 \times 0.04$

Pyroxene microphenocrysts $\mathrm{c}$

$(<(0.06 \times 0.07) / 0.6 \times 0.35)$

$0.13 \times 0.12$

Olivine microphenocrysts

(pseudomorphs) ${ }^{\mathrm{d}}$

$(0.04 \times 0.04 / 0.4 \times 0.3)$

$0.2 \times 0.16$

Groundmass plagioclase

$(<(0.03 \times 0.002) / 0.4 \times 0.04)$

$0.2 \times 0.02$

Groundmass pyroxene

isolated grains $(0.04 \times 0.04 \max )$

optically parallel units in

feathery varioles

$(0.05 />0.1)$

Opaque grains

elongate $(0.16 \times 0.016 \max )$

relatively equant

$(0.007 \times 0.007 / 0.037 \times 0.016)$

$0.018 \times 0.018$

Intersertal montmorillonite $\mathrm{e}^{\mathrm{C}}$

Calcite ${ }^{f}$

aK-feldspar was not seen in thin section, but traces were detected by $\mathrm{X}$-ray analysis (Appendix A); it may be enclosed in plagioclase.

bWholly altered to green, rarely deep red flaky minerals.

${ }^{c}$ Always glomeratic (Plate 4, Figures 5 and 6).

dAlways glomeratic (Plate 4, Figures 5 and 6); wholly altered to flaky pseudomorphs which include coarse, dusty, pleochroic flakes (iddingsite?) and green or turquoise celadonite(?).

eRarely form veins.

fOne anhedral patch that may be a pseudomorph after pyroxene.

17-169-12-1, 31-32 cm: Sample is medium gray basalt with a faintly blotchy appearance on sawed surfaces due to darker gray patches in a lighter gray mass. It is like 17-169-11-CC except that phenocrysts are absent. The microphenocrysts again represent a prolonged early stage of crystallization which produced large "glomerocrysts" and which was terminated by eruption and the chilling which led to crystallization of the variolitic groundmass.

Irregular joints contain dark Fe oxide and green to brown montmorillonite (and celadonite?). Dark Fe oxide also permeates the immediate wall rocks of the joints to some extent.

The rock is relatively fresh, except for altered olivine and intersertal montmorillonite, and was selected for isotopic and REE analyses (Tables 3 and 4; Figures 4 and 5). These and the major element chemistry (Table 1) suggest that the rock is an ocean ridge basalt; if so, the abundant early clinopyroxene indicates that the magma was fractionated. 


\begin{tabular}{lcc}
\hline \multicolumn{1}{c}{$\begin{array}{c}\text { Component } \\
(\mathrm{min} / \mathrm{max} \text { size }-\mathrm{mm})\end{array}$} & $\begin{array}{c}\text { Average } \\
\text { Size }(\mathrm{mm})\end{array}$ & $\begin{array}{c}\text { Volume } \\
(\%)\end{array}$ \\
\hline $\begin{array}{l}\text { Plagioclase microphenocrysts } \\
(0.1 \times 0.02 / 0.55 \times 0.1)\end{array}$ & $0.25 \times 0.03$ & 13.0 \\
$\begin{array}{l}\text { Pyroxene microphenocrysts } \mathrm{b} \\
(0.04 \times 0.04 / 1.0 \times 0.4)\end{array}$ & $0.12 \times 0.10$ & 23.7 \\
$\begin{array}{l}\text { Olivine microphenocrysts } \\
(\text { pseudomorphs } \mathrm{c}\end{array}$ & & \\
$(0.15 \times 0.08 / 0.7 \times 0.35)$ & $0.18 \times 0.12$ & 2.0 \\
$\begin{array}{l}\text { Groundmass plagioclase } \\
(\text { very small/0.45 } \times 0.02)\end{array}$ & & \\
Pyroxene varioles & & 5.8 \\
Opaque grains & & 41.0 \\
$(0.01 \times 0.01 / 0.1 \times 0.05)$ & & 5.6 \\
Groundmass montmorillonite & & 8.7 \\
Calcite & & 0.04 \\
\hline
\end{tabular}

aThe trace of K-feldspar seen by X-ray analysis (Appendix A) was not seen in thin section.

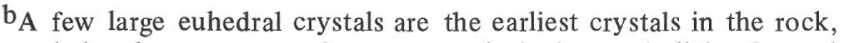
and the glomerocrysts of pyroxene, plagioclase and olivine formed around them.

cWholly altered to montmorillonite and a trace of calcite. Enclose minor opaque grains.

17-169-12-2, 0-2 cm: Basalt with a glassy selvage which dips about $45^{\circ}$; it may be the edge of a pillow. Most of the glass, especially the outer part, is altered to green and lesser grayish brown, soft, resinous montmorillonitic material. Fresh sideromelane survives mainly in the inner part of the selvage, and as rare patches in the outer part. Color laminations in the green altered glass outline blocks which may be relict from a stage of color-laminated palagonite which preceded in the diagenetic alteration. The grayish brown alteration is found mainly in the interiors of such blocks. The altered glass is cut by white to glassy, colorless phillipsite veins which are oriented parallel to the selvage.

The glass grades through sideromelane with isolated spherulites to a dense layer of spherulites (Plate 2, Figure 2). This layer is cut by veins of white calcite $\left(1.5\right.$ mole $\left.5 \mathrm{MgCO}_{3}\right)$ with green selvages of celadonite. The spherulitic layer also contains patches of light bottle green, soft, transparent, highly cracked material; the patches apparently are not amygdules; they resemble pseudomorphs after olivine except in lacking identifiable montmorillonite; they appear to be amorphous to X-rays (Appendix A); most likely they are alteration products of interstitial glass in the spherulite layer that had failed to devitrify.

17-169-12-2, 115-117 cm: Specimen is a densely chilled basalt that grades from a glassy selvage, through a zone of glass with isolated gray spherulites, to a continuous layer of spherulites (compare Plate 2, Figure 2) with interstitial brown altered glass, to gray microcrystalline basalt. Tapering projections of glass extend from the selvage into the spherulitic layer. The rock is cut be a dense network of veins which are locally so abundant that they isolate fragments of basalt as in a breccia. Most of the veins are calcite, 2 to $3 \mathrm{~mm}$ thick. In the glass, however, there are a few colorless, glassy, phillipsite veins. One such vein occurs along one wall of a tapering glass projection and gives way in the spherulitic layer to a vein of deep green celadonite that continues into the microcrystalline basalt. Thus, the vein population varies rapidly with depth in the rock. The bulk of the calcite in the veins has 0.5 to 1.0 mole $\% \mathrm{MgCO}_{3}$; these veins are vuggy, and large colorless crystals from the vugs are essentially pure $\mathrm{CaCO}_{3}\left(0 \% \mathrm{MgCO}_{3}\right)$. The calcite veins enclose gray masses of well-crystallized montmorillonite, and in places have selvages or lenses of black, shiny, well-crystallized montmorillonite along their walls. About one inch below the glassy selvage, an otherwise empty joint contains sporadic, discontinuous lenses or bulges of dark gray, well-crystallized montmorillonite. This montmorillonite is unaccompanied by calcite, but the joint projects into a calcite vein with selvages of celadonite.

The glassy selvage is altered to green, light brown or dark gray, resinous montmorillonitic material. The tapering glass projection along the phillipsite vein (see above) is altered to green and dark gray material. The $\mathrm{X}$-ray pattern (Appendix A) of the green altered glass with isolated gray spherulites indicates that the spherulites are pigeonite (or subcalcic augite), possibly with a trace of plagioclase. The green altered glass either contains very little montmorillonite or is composed of very poorly crystallized montmorillonite (very weak X-ray peaks; see Appendix A and is essentially a green "palagonite" of diagenetic origin. Poorly crystallized montmorillonite is apparently typical of altered glass in oceanic basalts.

The altered interstitial glass in the spherulitic layer is brown. The spherulitic layer also contains tiny, irregular patches of transparent, highly cracked, light bottle green material, similar to that in $17-169-12-2,0-2 \mathrm{~cm}$. This material may be pseudomorphs after olivine microphenocrysts or altered interstitial glass.

The microcrystalline layer resembles the glomerophyric basalts immediately above, but shows the effects of more radical chilling. The glomerocrysts here are relatively smaller and less abundant, and are not seriate with, but rather strongly contrasted with, the groundmass. The groundmass is composed mainly of extremely fine-grained, red brown, subradial, in places feathery, varioles; it also contains a significant amount of distinct plagioclase and pyroxene grains. The textures indicate that the early stage of crystallization of the microcrystalline layer, during which the glomerophenocrysts formed, took place at, or very near, the surface, so that some degree of chilling affected the grain size and abundance of the glomerocrysts; but that the chilling, though fast, was distinctly less rapid than that of the spherulitic and glassy layers. This specimen and $17-169-12-2,0-2 \mathrm{~cm}$ are probably from a series of pillows or thin flow units.

The glomerocrysts are composed of pyroxene, plagioclase, and altered olivine. The pyroxene is relatively abundant, colorless, in some cases coarse and ophitic, and, in some grains, twinned. The coarseness and early crystallization, as in the overlying baslats, suggest a fractionated magma, if the rock is an ocean ridge basalt.

Olivine occurred originally as large isolated phenocrysts and as a component of the glomerocrysts. It is wholly altered to either green or light brown montmorillonite (smaller grains) or to light brown rimmed by green montmorillonite (larger grains). The green flakes are generally coarser than the brown and occur in parallel aggregates; the brown are very fine-grained and randomly oriented. The brown alteration may contain spots or a "grid" of red Fe-oxide stain.

Opaque minerals occur in the groundmass as equant, anhedral grains, or, uncommonly, as slightly elongate grains.

\section{SITE 170}

Recovery was so poor at this site that it is difficult to estimate the volcanic contributions to the sediment. Probably much of the hole was in zeolitic brown clay with moderate amounts of volcanic components, now largely altered to phillipsite and montmorillonite.

Core 15 recovered about 2 meters of zeolitic mudstone and sandstone of volcanic origin. The abundant glass and lesser pyroxene, feldspar, and palagonite of the bluish gray volcanic sandstone are less altered than the overlying mudstone which is characterized by phillipsite, analcite, sparry calcite, celadonite and montmorillonite. The mudstone is laminated and contains nannofossils. It may be reworked hyaloclastite with the finer volcanic grains mixed with a pelagic or reworked pelagic component, or it may have been a tuff.

Mugearite (Plate 4, Figure 7), the most differentiated igneous rock recovered during Leg 17 (Table 1; Figures 1, 2, 3 and 4) was penetrated at 150 meters depth in Santonian or Coniacian sediments. It was recovered only in a disoriented core catcher sample. Not one of the pieces had been cut by the drill or had been freshly broken. The angular, unabraded shapes of the small blocks suggest that they are joint blocks from a flow or sill. Neither the drilling rate nor the seismic record indicates any hard layer to be present, so perhaps the flow or sill was very thin and jointed, or the pieces were clasts in a thin bed of rubble that slumped from some 
nearby extrusion, or they were clasts in a gravelly turbidite. Except for minor montmorillonite in the body of the rock, thin dark rims around the edges of the blocks, and montmorillonite-coated joint surfaces, the rock is fairly fresh, comparable to the alkalic rocks at Hole 165A. The freshness may in part be related to age, if the rock is from a young sill, but the main factors may be fine grain size and primary hydrous minerals. In the high- $\mathrm{CO}_{2}$ environment of this carbonate-rich sediment section, we do not expect the zeolitic type of alteration found at Hole $165 \mathrm{~A}$. We expect, instead, if alkalic rocks in this type of environment react diagenetically in the same manner as tholeiitic rocks (compare Sites 167 and 171 in particular), the preservation of plagioclase and removal of pyroxene. The plagioclase is indeed fresh and pyroxene is absent, presumably replaced by the montmorillonite.

The basement(?), at 172 meters depth, is a highly altered, nonvesicular, aphyric to slightly microphyric, coarse-grained basalt to fine-grained diabase. Originally it had intergranular to subophitic texture, but now, in the shallower specimens, it is largely with intersertal texture as a result of extensive, almost complete replacement of pyroxene by montmorillonite, celadonite, and calcite (Plate 4, Figure 8; Plate 5, Figures 1, 2, and 3). Trace element chemistry (Figures 1, 2 and 3) indicates affinities with ocean island tholeiites rather than with basalts from spreading ridges (Table 1). If the intense alteration, which has largely destroyed clinopyroxene, caused a loss of trace elements, then the rock may even have been alkaline. This possibility is supported by mineral features such as pyroxenes with distinct light brown or slightly violet colors, prominent accessory amounts of biotite, and early crystallization of pyroxene. Pyroxene is in fact the dominant microphenocryst and pseudomorphs after olivine are notably scarce. Taken alone, the early pyroxene might indicate a fractionated ocean ridge basalt; but, in conjunction with other evidence, it indicates a rock with alkaline or ocean island tholeiitic affinities.

The upper contact was not examined; the shallowest specimen $(16-1,17-24 \mathrm{~cm})$ shows a rapid increase of grain size from fine- to medium-grained basalt (Plate 4, Figure 8); the next lower specimen $(16-1,24-37 \mathrm{~cm})$ shows a slower increase from medium- to coarse-grained basalt (Plate 5, Figure 1); and specimens over the next meter and a half are mostly coarse-grained basalt, coarsening slowly to fine-grained diabase in the deepest specimen (16-2, $135-150 \mathrm{~cm}$ ) (Plate 5, Figure 3). The grain size variation suggests that all specimens belong to the same body, and that the shallowest specimen came from very near the upper contact. No sample contains glass or altered glass, or exhibits variolitic or spherulitic texture or any other feature commonly associated with the rapidly quenched pillows commonly recovered from the crests of spreading ridges. These facts, together with the coarse grain size, suggest that the body is a sill. Brown amphibole in the uppermost part of the shallowest specimen probably crystallized as the magma absorbed water from the overlying sediments (compare the sill at Site 169); the amphibole supports the suggestion that the shallowest specimen is from very near the upper contact. The paucity or absence of veins, except near the contact, indicates a relatively unbrecciated body that may not have experienced the mechanical effects attending the spreading process near a ridge crest (compare Hole $165 \mathrm{~A})$. A relatively hydrous magma is indicated by primary amphibole and biotite, and deuteric amphibole (Plate 5, Figure 2), chlorite, and possibly mixed-layer chlorite-montmorillonite. This fact and the absence of vesicles indicate emplacement at great depth and high pressure. The collective evidence indicates a sill emplaced in the oceanic crust some distance from an active spreading center, and implies, as at Hole $165 \mathrm{~A}$, the possibility of a sediment section below the sill, overlying Layer 2 at still greater depth. These conclusions are consistent with the chemical evidence (Table 1) which indicates that the rocks are more alkaline than ocean-ridge basalts, being closely akin to ocean island tholeiites or even more alkaline rocks.

The primary opaque minerals are moderately titaniferous, titanomagnetite, and ilmenite. This somewhat oxidized assemblage is consistent with the significant, but not high water content of the magma. Near the surface of the sill $(16-1,24-37 \mathrm{~cm})$ the assemblage is ilmenite and almost pure magnetite. If the magnetite is primary, it may reflect more intensely oxidizing conditions related to a higher water content in the magma. However, the assemblage includes anatase, a fact which suggests that the magnetite is a diagenetic alteration product of titanomagnetite (see below).

Biotite formed as a late, primary hydrous phase, and possibly in part as an alteration product of titanomagnetite.

Late deuteric effects include formation of chlorite, amphibole, and, possibly, mixed-layer chlorite-montmorillonite in the late interstitial residuum (Plate 5, Figure 2); possible slight alteration of pyroxene to amphibole; and possibly some chloritization of biotite. Amphibole increases downward in the cored interval, as expected for a deuteric mineral from the surface to the interior of a sill.

Diagenetic effects appear to be controlled by the diffusion of various "fronts" from the upper surface into the interior of the sill. In general, the fronts are apparently quite regular, except for one zone (see below), and the regularity is evidently controlled by the impervious, homogeneous, unfractured nature of the rock. The most rapidly advancing fronts are those of $\mathrm{H}_{2} \mathrm{O}$ and $\mathrm{S}$. Water has converted all interstitial residuum to montmorillonite to the greatest depth penetrated. Similarly, conversion of pyroxene to montmorillonite is almost complete except in the lowest sample (16-2, $135-150 \mathrm{~cm}$ ), and even there the alteration is extensive (Plate 5 , Figures 1, 2, and 3). The preservation of some pyroxene is due, not to the unavailability of water, but to the slow rate of alteration of pyroxene compared to that of the interstitial residuum. The $S$ front produce pyrite to the greatest depths cored. Although the pyrite may be in part a primary or deuteric sulfide which was initially dispersed and later concentrated locally during recrystallization, its abundance seems to vary sympathetically with that of montmorillonite (general decrease with depth), and this fact suggests that the pyrite is diagenetic and that the $\mathrm{S}$ front either arrived early, diffused fast, or both.

The next most rapidly advancing front is that of $\mathrm{K}$, which has allowed replacement of the calcic cores of plagioclase by K-feldspar at least as deep as $16-2,61-70 \mathrm{~cm}$, and possibly as deep as 16-2, $135-150 \mathrm{~cm}$.

Next fastest is an oxygen front which has caused oxidation of titanomagnetite at least as deep as the middle of 16-1, 24-37 cm. The oxidation front is not sharp but spread out over a steep gradient: in 16-1, 17-24 $\mathrm{cm}$ the assemblage is maghemo-magnetite plus anatase, with little if any ilmenite; in the middle of 16-1,24-37 $\mathrm{cm}$ the assemblage is magnetite-anatase-ilmenite; and in 16-2, $135-150 \mathrm{~cm}$ it is titanomagnetite plus ilmenite (see Appendix A and Table 5). A possible explanation for the gradient is, perhaps, that titanomagnetite does not necessarily oxidize directly to its most extreme products, namely maghemite and anatase, but progressively through Ti-poorer titanomagnetites, to magnetite, to maghemomagnetite and finally to magneto-maghemite, accompanied at all stages by continuously increasing amounts of anatase (leucoxene). Within this strong gradient, about $2 \mathrm{~cm}$ below the top of $16-1$, 24-37 cm, is a fairly sharp, subhorizontal contact between blue greenish gray basalt above and brown gray basalt below. The blue green color is due to celadonite which has completely replaced groundmass pyroxene, interstitial residuum, and olivine microphenocrysts. The same textural role is played by montmorillonite below the contact, and it is possible, or even probable, that celadonite did not form directly from the primary phases (except perhaps in the topmost skin of the sill), but replaced earlier diagenetic montmorillonite. The celadonite front does not correspond to the $\mathrm{K}$ front because diagenetic $\mathrm{K}$-feldspar is present below the contact. The contact may be controlled by kinetic factors coupled somehow to the oxidation of titanomagnetite and mafic minerals. Conceivably, the oxidation controls the availability of free $\mathrm{Fe}^{+++}$, which reacts to form celadonite. Any $\mathrm{K}$ not so precipitated moves on until it reacts to replace plagioclase or, where $\mathrm{Fe}^{+++}$is locally available, is precipitated as local patches and veins of celadonite of a type seen rarely in $16-1,24-37 \mathrm{~cm}$ below the contact.

This situation may be contrasted with that in the upper contact zone of the sill at Site 169 where diagenetic K-feldspar and maghemite are abundant. There the oxidation reactions may have been so fast and complete that the limited oxygen supply was continuously exhausted and the movement of the oxygen front retarded as the $\mathrm{K}$ front moved ahead. The lack of available $\mathrm{Fe}^{+++}$ led to precipitation of the $\mathrm{K}$ as $\mathrm{K}$-feldspar. The rate of oxidation of titanomagnetite, and the consequent degree of retardation of the 
oxygen front, may be controlled by its initial composition in such a manner that Ti-richer titanomagnetites (as at Site 169), being more reduced and further from equilibrium, react faster, whereas Ti-poorer titanomagnetites, as at Site 170 , react more slowly. Other factors that may influence reaction and diffusion rates are treated in the general remarks on specimen 16-1, 24-37 cm (see below).

Almost horizontal veins are abundant in $16-1,17-24 \mathrm{~cm}$ and the upper part of 16-1, 24-37 cm, and large ovoidal patches are present in both specimens. The contents of the patches and veins conform to their host rocks as regards the presence of celadonite. Thus, patches and veins above the contact are filled by celadonite with, at most, subordinate amounts of calcite, whereas patches and veins below the contact are filled with pure calcite. One vein crosses the contact at a low angle and is filled with celadonite and calcite above the contact and with calcite alone below the contact. These relations indicate that the processes of vein filling and the formation of ovoidal patches are not controlled by the free, bulk flow of diagenetic fluids, but by diffusion and approaches to local chemical equilibrium, regardless of the size of the vein or patch.

An exception to these statements is posed by an interval in Core 16 , Section 2, extending from about $89 \mathrm{~cm}$ to deeper than $118 \mathrm{~cm}$ (but not so deep as $135 \mathrm{~cm}$ ), in which the late interstitial residuum is replaced by calcite rather than montmorillonite, and pyrite is deeply tarnished or completely oxidized to orange brown Fe oxides. The zone, which does not contain obvious amygdules, was quite pervious to $\mathrm{CO}_{2}$ and oxygen, in contrast to the rocks above and below where pyrite is fresh and calcite is rarely present in more than trace to minor amounts. The zone in its present form is not a zone of primary magmatic oxidation because the pyrite which has been oxidized is of diagenetic origin; originally, however, it could conceivably have been an oxidized zone in the sill.

The general circumstances of diagenetic alteration were conditioned by a high activity of $\mathrm{CO}_{2}$ controlled, as at Sites 167 and 171 , by a fairly carbonate-rich sediment section. At all these sites, pyroxene was replaced by montmorillonite and $\mathrm{Ca}$ was mobilized. Ca was precipitated as calcite wherever large voids (joints and vesicles) were available. On the other hand, calcite did not compete well with montmorillonite for microspaces within the host rock. The alteration of pyroxene and groundmass evidently did not involve removal followed by infilling of the resulting voids. Instead, solution of pyroxene or interstitial matter occurred essentially simultaneously with precipitation of montmorillonite, so that the microvoids amounted to no more than intergranular films which facilitated diffusion. The montmorillonite is so fine-grained and randomly oriented that one cannot reasonably postulate an epitaxial control for its deposition, especially in those cases where glass was replaced, so its successful competition with calcite for the microvoids must depend on other factors. In zeolitic alteration (low $\mathrm{CO}_{2}$ activity) the pyroxene is largely unaffected (see Hole $165 \mathrm{~A}$ ), so the effect of $\mathrm{CO}_{2}$ on pyroxene must be direct; in other words, $\mathrm{CO}_{3}=$ and $\mathrm{HCO}_{3}{ }^{-}$ions must diffuse into and out of the intergranular films. The failure to precipitate calcite must depend, therefore, on chemical gradients which lead to diffusion of $\mathrm{Ca}$ out of the system into large voids. This leads to the low $\mathrm{CaO}$ values found in those basalts altered in high- $\mathrm{CO}_{2}$ environments, such as at Sites 167 and 171, and, most notably, at Site 170. (Veins and large patches of calcite were avoided in selecting samples for chemical analysis because the local origin of the $\mathrm{Ca}$ could not be assured. Inclusion of the veins and patches in the analyzed material would have raised the $\mathrm{CaO}$ contents while introducing other anomalies.) Thus, even where secondary calcite is absent or minor, one can reasonably infer that the alteration occurred in an environment of high $\mathrm{CO}_{2}$ activity if pyroxene is altered to montmorillonite and $\mathrm{CaO}$ is low.

\section{Petrography}

17-170-10-CC: This is an angular joint block of medium to dark gray, chilled, porphyritic mugearite (Table 1). It is fairly fresh except for a relatively dark gray rim on the block. Modally the rock is variable as judged from the variation of amphibole peak heights in the total rock X-ray patterns of the weathered rim and relatively fresh interior (Appendix A). Apatite is so abundant that its peaks show up clearly in the total rock X-ray patterns. The surfaces of the joint-bounded specimen and of vesicles in it are coated by green to yellow green vermicular material. X-ray analysis (Appendix A) indicates that it is montmorillonite with $\mathrm{d}_{(060)}=1.51 \AA$; this d-value and the rock chemistry indicate a dioctahedral, probably aluminous montmorillonite, in contrast to the trioctahedral montmorillonites in the basalts and diabases deeper in this hole.

The shape of the sample and the coating suggest a joint-bounded block from a flow or sill, not a transported, abraded clast from a gravel; but a gravelly turbidite source cannot be excluded. A close examination of all fragments in the core catcher sample may resolve this question. If the mugearite is from a thin flow or sill, pieces of the chilled contacts may be present.

Chemically the rock is a mugearite (Table 1). Mineralogically it is remarkable in having no mafic phenocrysts other than a few of magnetite (Plate 4, Figure 7).

\begin{tabular}{llc}
\hline \multicolumn{1}{c}{$\begin{array}{c}\text { Component } \\
(\mathrm{min} / \mathrm{max} \text { size }-\mathrm{mm})\end{array}$} & $\begin{array}{c}\text { Average } \\
\text { Size }(\mathrm{mm})\end{array}$ & $\begin{array}{c}\text { Volume } \\
(\%)\end{array}$ \\
\hline $\begin{array}{l}\text { Plagioclase phenocrysts } \\
(0.40 \times 0.14 / 1.26 \times 0.63)\end{array}$ & $0.72 \times 0.14$ & 12.1 \\
$\begin{array}{l}\text { Plagioclase microphenocrysts } \\
(<0.056 \times 0.004 / 0.64 \times 0.03)\end{array}$ & $0.13 \times 0.01$ & 10.6 \\
$\begin{array}{l}\text { Equant opaque grains } \mathrm{b} \\
(0.01 \times 0.01 / 0.11 \times 0.09)\end{array}$ & 2.6 \\
$\begin{array}{l}\text { Finely dendritic ilmenite } \\
\quad(\text { groundmass })\end{array}$ & \\
$\begin{array}{l}\text { Groundmass } \\
\text { Vesicles }\end{array}$ & & 17.8 \\
\hline
\end{tabular}

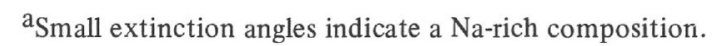

$b_{\text {Equant, euhedral cubes; isolated or locally clustered (chains of } 3 \text { or }}$ 4 synneuretic grains), but not glomeratic in the usual sense (Plate 4, Figure 7); may occur as inclusions in plagioclase phenocrysts.

${ }^{\mathrm{c}}$ Mainly brown mica, brown amphibole, and green montmorillonite, and also includes apatite (see Appendix A).

${ }^{d}$ Mostly tiny, irregular to ovoid vesicles, some of which are empty, but most of which are partly or wholly filled with green, very fine-grained montmorillonite. Larger vesicles (up to $1^{+} \mathrm{mm}$ ) are uncommon; they are lined by terminated plagioclase crystals coated by green montmorillonite. Vesicles in the interior of the specimen are, on the average, larger and less commonly filled than those in the dark, altered rim; this fact indicates that the montmorillonite is probably diagenetic, and supports the interpretation that the specimen is a natural joint block which has suffered little or no abrasion.

17-170-16-1, 17-29 cm: Specimen is a coarse-grained, nonvesicular, medium blue greenish gray, slightly microphyric basalt with diabasic intersertal, nonvariolitic texture (Plate 4, Figure 8). The grain size increases noticeably downward, and the average is markedly less than that of the specimen immediately below (Plate 5, Figure 1); this gradation suggests that the top of this specimen is near, but not quite at, the top of the flow or sill. Celadonite replaces the interstitial residuum and pyroxene(?), and fills vesicles, thus imparting the blue green color; very likely, to judge from relations in deeper specimens, the celadonite replaced montmorillonite which once played the same textural and paragenetic roles as the celadonite now does. Two distinct patches are present. One is smoothly ovoidal, almost $2 \mathrm{~cm}$ in maximum dimension, and is composed of a light turquoise calcite-celadonite mixture with a concentration of somewhat darker, but still light turquoise, celadonite in a rim $1 \mathrm{~mm}$ thick. The other patch, almost $1 \mathrm{~cm}$ in maximum dimension, is an irregularly intermixed earthy brown goethite and resinous dark green celadonite. The goethite may be altered pyrite. Subhorizontal veins about $1 \mathrm{~mm}$ wide are composed either wholly of light turquoise celadonite, or, more commonly, of a continuous or discontinuous core of light turquoise or medium blue green celadonite within selvages of dark green celadonite of variable thickness. Calcite is either absent from the veins or present in 
subordinate amounts. Minor K-feldspar is present (Appendix A), but its mode of occurrence is unknown; it probably replaces plagioclase. The rock is generally of tholeiitic aspect. However, early crystallization of pyroxene indicates that the magma was either fractionated or had alkaline affinities. Chemical data (Table 1, Figures 1, 2, and 3) indicate ocean island tholeiitic or slightly alkaline affinities; but the effects of metasomatism are so strong that any conclusion is very uncertain. The opaque minerals are oxidized to maghemite (actually maghemo-magnetite) plus anatase.

\begin{tabular}{|c|c|c|}
\hline $\begin{array}{c}\text { Component } \\
(\mathrm{min} / \mathrm{max} \text { size }-\mathrm{mm})\end{array}$ & $\begin{array}{l}\text { Average } \\
\text { Size }(\mathrm{mm})\end{array}$ & $\begin{array}{l}\text { Volume } \\
(\%)\end{array}$ \\
\hline $\begin{array}{l}\text { Pyroxene microphenocrysts }{ }^{\mathrm{a}} \\
(0.12 \times 0.12 / 0.8 \times 0.36)\end{array}$ & $0.2 \times 0.15$ & 1.2 \\
\hline $\begin{array}{l}\text { Olivine microphenocrysts } \\
\text { (pseudomorphs) } \\
(0.2 \times 0.13 / 0.45 \times 0.32)\end{array}$ & $0.2 \times 0.2$ & 0.6 \\
\hline $\begin{array}{l}\text { Plagioclase microphenocrysts }{ }^{c} \\
(0.17 \times 0.04 / 0.5 \times 0.04)\end{array}$ & $0.3 \times 0.04$ & 0.4 \\
\hline $\begin{array}{l}\text { Groundmass plagioclase } \\
(0.03 \times 0.008 / 0.2 \times 0.01)\end{array}$ & $0.04 \times 0.013$ & 18.0 \\
\hline $\begin{array}{l}\text { Opaque and brown translucent } \\
\text { grains } \mathrm{d} \\
\text { equant }(0.1 / 0.03) \\
\text { elongate }\end{array}$ & $0.04 \times 0.02$ & 16.6 \\
\hline Celadonite and brown amphibole $\mathrm{e}^{\mathrm{e}}$ & & 53.1 \\
\hline $\begin{array}{l}\text { Interstitial mass }{ }^{f} \\
(<0.002)\end{array}$ & & 9.8 \\
\hline Calcite replacing microphenocrysts $\mathrm{g}$ & & 0.2 \\
\hline
\end{tabular}

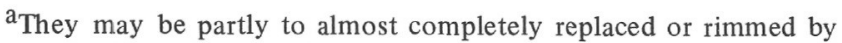
calcite (Plate 4, Figure 8).

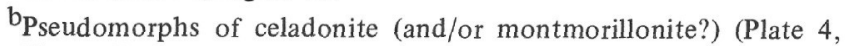
Figure 8); they may have calcite fringes.

${ }^{\mathrm{c}}$ Fresh except for rare patches of calcite.

${ }^{\mathrm{d}} \mathrm{X}$-ray analysis (Appendix A) indicates maghemite (actually maghemo-magnetite), minor anatase, and a questionable trace of ilmenite. The brown translucent grains are probably goethite.

${ }^{\mathrm{e}}$ The X-ray data (Appendix A) indicate that the celadonite may enclose traces of montmorillonite. While the celadonite may have replaced pyroxene (which is notably minor in so coarse-grained a rock) and interstitial residuum directly, relations in deeper specimens indicate that it more likely replaced montmorillonite which had earlier replaced the pyroxene and interstitial residuum. The brown amphibole, which is present in accessory amounts only, is distinct from the colorless, acicular, deuteric amphibole in deeper specimens in this hole. It is found only in this uppermost specimen from the basement, and more abundantly in the upper part of the specimen than farther down. It probably crystallized as a primary magmatic mineral near the upper contact of the sill as water diffused into the magma from the overlying sediments.

${ }^{f}$ Extremely fine-grained celadonite, feldspar (plagioclase; and possibly the K-feldspar indicated by the X-ray data), opaque minerals, and possibly a trace of montmorillonite. Also includes large amounts of a high-relief mineral which may be sphene, anatase, or epidote. Where this mineral is very abundant, it appears to occupy the cores of plagioclase laths. This fact suggests saussuritic epidote, which would in turn suggest hydrothermal alteration, of which there are no other indications in this particular specimen, but which is suggested by traces of chlorite and deuteric amphibole in specimens from deeper in this hole.

gOccurs mainly as a replacement of pyroxene microphenocrysts (Plate 4, Figure 8) less commonly it occurs in pseudomorphs after olivine, and rarely as a replacement of plagioclase microphenocrysts.
17-170-16-1, 24-37 cm: Specimen is a coarse-grained, nonvesicular basalt or fine-grained diabase; coarser than 17-170-16-1, $17-24 \mathrm{~cm}$ and probably from the same flow unit or sill. The top 2 to $3 \mathrm{~cm}$ are blue greenish gray basalt bounded fairly sharply along a subhorizontal contact against brownish gray basalt below. The megascopic difference is one of color only, not grain size or texture. The contact is a metasomatic or reaction front, expressed mineralogically by celadonite, which advanced by diffusion from above. Within the blue greenish gray basalt there are veins composed of celadonite with minor patches of calcite, as in 17-170-16-1, 17-24 $\mathrm{cm}$. In the brownish gray basalt, there are sparse veins and a larger (greater than $3 \mathrm{~cm}$ in maximum dimension) ovoid patch composed of calcite. An almost flat vein which crosses the slightly dipping contact is calcite within the brownish gray basalt, and grades to celadonite plus abundant calcite in the blue greenish gray basalt. The metasomatic or reaction front thus seems to affect veins as well as the host rock, and this fact suggests that vein filling, like the diagenetic alteration, is at least partly controlled by diffusion rather than free bulk flow of fluids. Both rock types contain tiny specks of calcite, which are visible by effervescence in cold $1 \mathrm{~N} \mathrm{HCl}$, but the specks are much more abundant in the brownish gray basalt.

The opaque minerals from the brownish gray basalt, a few centimeters below the contact, are almost pure magnetite plus minor ilmenite and anatase (Appendix A and Table 5). This assemblage contrasts with the maghemite plus anatase above, and the moderately titaniferous titanomagnetite plus ilmenite below. The presence of anatase suggests that the magnetite formed diagenetically from titanomagnetite rather than magmatically. This conclusion suggests, in turn, that the oxidation of titanomagnetite to maghemite is not necessarily direct, but may (must?) lead through intermediate titanomagnetites of progressively lower $\mathrm{Ti}$ contents, to magnetite, thence through maghemo-magnetite to maghemite. These conclusions suggest also that an oxygen front has moved farther into the rock than the celadonite front.

Below the celadonite front there are minor diagenetic K-rich minerals, including both K-feldspar and local patches or seams of celadonite. These may be controlled by highly permeable microchannels, or else the main celadonite front may be controlled, not only by availability of $K$, but also by the release of other constituents needed for celadonite $\left(\mathrm{Fe}^{+++}\right.$and $\left.\mathrm{Si}\right)$. In fact, the large increase of $\mathrm{SiO}_{2}$ above the celadonite front (Table 1) suggests that it may depend partly, or primarily, on an advancing $\mathrm{SiO}_{2}$ front. The $\mathrm{K}$ not precipitated at the front may move on to form K-feldspar, probably by replacement of plagioclase, or, where $\mathrm{Fe}^{+++}$is locally available, minor patches or veins of celadonite. If this reasoning is correct, the celadonite front may be coupled to, or dependent on, an oxygen front that moves with or somewhat behind the $\mathrm{K}$ front. The upper contact of the sill in 17-169-5-1, 21-24 $\mathrm{cm}$ is rich in diagenetic K-feldspar and maghemite, but lacks celadonite (which is present in the underlying basement basalts at Site 169) and would seem to contradict these conclusions. However, the sill at Site 169 may be a case in which the $\mathrm{K}$ front came so much earlier or moved so much faster than the oxygen front, that $\mathrm{Fe}^{+++}$was not available to combine with the $\mathrm{K}$. The rate of movement of the oxygen front may be controlled by the susceptibility of the primary opaque minerals to oxidation. The highly reduced, Ti-rich titanomagnetite of the sill at Site 169 may be much more susceptible to oxidation than the relatively oxidized assemblage of ilmenite plus moderately titaniferous titanomagnetite found in the present rock. The oxygen front would advance more slowly through the rock with the more reduced assemblage because of rapid consumption of available oxygen.

The rate of movement of the oxygen and $\mathrm{K}$ fronts would also be influenced by the micropermeability of the rock. A rock rich in diagenetic montmorillonite, like the present one (Plate 5, Figure 1), is probably more porous and open than one in which the groundmass is composed largely of deuteric chlorite, as in the sill at Site 169. However, because of rapid immobilization of $\mathrm{K}$ in exchangeable surface and interlayer cation sites in montmorillonite, it may not be able to move rapidly through even a highly permeable rock if that permeability depends on the presence of montmorillonite. Such a rock would behave as a semipermeable, or perhaps even impermeable, membrane which would retard $\mathrm{K}$ until the exchangeable sites were saturated (i.e., interlayer $\mathrm{K} / \mathrm{Na}$ had equilibrated with $\mathrm{K} / \mathrm{Na}$ of the pore fluid). The montmorillonitic rocks of 
the present basaltic body have the highest $\mathrm{K}$ contents of all montmorillonite-rich rocks recovered during Leg 17 . They indicate an abundant supply of $\mathrm{K}$ which may, indeed, have saturated the montmorillonite in the upper meter of the body, so that thereafter the diffusion of $\mathrm{K}$ through the saturated zone into the lower parts of the body took place rapidly. The monotonic decrease of $\mathrm{K}$ with depth (Table 1) supports this suggestion. Very likely the replacement of plagioclase by K-feldspar at any given level will not proceed until the surrounding montmorillonite is saturated. In support of this suggestion, contrast the three most altered and most highly montmorillonitic basalts from Leg 17 . The $\mathrm{K}$ contents decrease from the lower unit at Site 170 , to the rocks at Site 167, to the upper, pillowed unit at Site 171. Diagenetic K-feldspar decreases in the same order, and is in fact undetected at Site 171. Furthermore, at Sites 167 and 170 the abundance of K-feldspar decreases with depth, suggesting that only the montmorillonite in the upper parts of the basalt units is saturated with K. At Site 171, it is unsaturated at any level.

In summary, in comparing the present rock with the sill at Site 169 , the relatively more rapid advance of the oxygen front, compared to the $\mathrm{K}$ front, in the present sample might be due to a relatively slow reaction of oxygen to form diagenetic minerals and an abundant supply of $\mathrm{K}$; thus, $\mathrm{K}$ was always available to react to form celadonite where the reaction of oxygen on Fe-bearing minerals provided available $\mathrm{Fe}^{+++}$, and moved on to form $\mathrm{K}$-feldspar (or to saturate montmorillonite) deeper in the rock where it did not. The relatively slower advance of the oxygen front in the sill at Site 169 might be due to a reversal of these factors, such that $\mathrm{K}$ was not always available when $\mathrm{Fe}^{+++}$was produced, and the $\mathrm{Fe}^{+++}$precipitated as maghemite. The apparently slower advance of both the $\mathrm{K}$ and oxygen fronts in the sill at Site 169 , relative to their rates in the present sample, might be due to the much less porous chloritic groundmass in the sill compared to the highly porous, K-saturated, montmorillonitic groundmass here. A general conclusion would also be that the water front, which controls the formation of montmorillonite, diffuses much faster than either the oxygen or the $\mathrm{K}$ front. Bass has inferred a similar relative rate in spilitic and zeolitic metasomatism of metabasalts dredged from the Gulf of Panama. There, Na reacted and was arrested near joint faces, while $\mathrm{H}_{2} \mathrm{O}$ permeated the whole of joint-bounded blocks. (See the discussion of Hole 165A for further comments on the matter of spilitic and zeolitic metasomatism.)

17-170-16-1, 32-37 cm: Specimen is a coarse-grained, nonvesicular, brownish gray, highly altered, almost aphyric basalt, about 8 to $12 \mathrm{~cm}$ below the lower contact of the blue greenish gray basalt. Montmorillonite plays the same textural role in this rock as does celadonite in the blue greenish gray rocks above the contact. The texture is diabasic intersertal (Plate 5, Figure 1); originally it may have been intergranular to subophitic before the pyroxene was altered to montmorillonite. The rock is cut by calcite- veins and contains large calcite ovoids. No pseudomorphs after olivine were seen. The only microphenocrysts are pyroxene (Plate 5, Figure 1 ), a fact which suggests a fractionated tholeiitic magma or one with mildly alkaline affinities. The chemistry (Table 1, Figures 1, 2, and 3 ) indicates affinities with ocean island tholeiites, and prior to alteration of pyroxene, which may have been accompanied by loss of trace elements, it may have been distinctly alkaline. Traces of chlorite (Appendix A) suggest that the rock is from the interior of a sill or thick flow where deuteric alteration occurred.

\begin{tabular}{lcc}
\hline $\begin{array}{c}\text { Component } \\
(\mathrm{min} / \mathrm{max} \text { size }-\mathrm{mm})\end{array}$ & $\begin{array}{c}\text { Average } \\
\text { Size }(\mathrm{mm})\end{array}$ & $\begin{array}{c}\text { Volume } \\
(\%)\end{array}$ \\
\hline $\begin{array}{l}\text { Pyroxene microphenocrysts } \\
(0.3 \times 0.25 / 0.7 \times 0.5)\end{array}$ & 0.3 \\
$\begin{array}{l}\text { Groundmass pyroxene } \\
(0.07 \times 0.04 / 0.16 \times 0.11)\end{array}$ & $0.1 \times 0.1$ & 5.2 \\
$\begin{array}{l}\text { Groundmass plagioclase (and } \\
\text { trace of K-feldspar) }\end{array}$ & $0.25 \times 0.04$ & 34.7 \\
$(0.09 \times 0.02 / 0.65 \times 08)$ & &
\end{tabular}

$(0.09 \times 0.02 / 0.65 \times 0.08)$
Opaque minerals $\mathrm{c}$

equant $(0.02 / 0.1 \times 0.06)$

elongate $(0.13 \times 0.02 / 0.35 \times 0.03)$

Intersertal Montmorillonite $\mathrm{d}$

48.7

Apatite

Trace

$\mathrm{Mica}^{\mathrm{e}}$

Trace

Calcite $^{\mathrm{f}}$

${ }^{\mathrm{a}}$ See Plate 5, Figure 1.

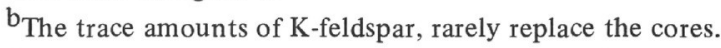

${ }^{c} \mathrm{X}$-ray analysis of opaque minerals from a sample taken immediately above the sectioned sample (Appendix A and Table 5) indicates nearly pure magnetite plus minor anatase and ilmenite. A trace of yellow sulfide was seen under the binocular microscope.

$\mathrm{d}_{\text {It probably encloses the chlorite and mica (celadonite?) identified }}$ in the X-ray patterns (Appendix A). The mica is probably diagenetic. The chlorite is probably deuteric, and formed by alteration of the late interstitial residuum, or perhaps as deuteric reaction fringes around titanomagnetite (Plate 5, Figure 1).

${ }^{e}$ One flake of white mica, the only one identified optically. It may be celadonite or bleached biotite.

$\mathrm{f}_{\text {Irregular and euhedral patches; mainly intersertal, but some replace }}$ pyroxene.

17-170-16-1, 71-77 cm: Specimen is a brownish gray, nonvesicular, coarse-grained basalt, with a moderate number of greenish tinged, dark grayish brown (i.e., olive brown) "amygdules" (similar "amygdules" are more numerous in 17-170-16-2, 0-14 cm; they may be altered chlorophaeite; compare Sites 167 and 171). The color of the "amygdules" is not that typical of celadonite. Total rock X-ray analysis (Appendix A) indicates montmorillonite, plagioclase, minor clinopyroxene, and traces of ilmenite, K-feldspar, chlorite, and mica(?). Apparently the pyroxene was largely replaced by montmorillonite. No veins, ovoids, or specks of calcite are present, only rare, irregular patches. The chlorite indicates deuteric alteration. No veins or joints of any sort are present; the rock is mechanically intact.

17-170-16-1, 115-119 $\mathrm{cm}$ : Specimen is a brownish gray, nonvesicular, coarse-grained basalt, as above. No calcite of any sort is visible. Total rock X-ray analysis (Appendix A) indicates plagioclase and montmorillonite; minor clinopyroxene and K-feldspar; and traces of ilmenite, mica and chlorite (and possibly mixed-layer chlorite-montmorillonite). Again, deuteric alteration is indicated and also, no veins or joints are present.

17-170-16-2, 0-14 cm: Specimen is brownish gray, nonvesicular, coarse-grained basalt, with abundant patches of olive brown montmorillonite. The patches are mostly irregular and intersertal; the largest one is about $5 \times 3 \mathrm{~mm}$. They may contain dark "prisms", in many cases in subradial variole-like arrays, in other cases in randomly scattered arrays. The variole-like arrays may be textural relics of quench pyroxene, although this seems unlikely in so coarse-grained a basalt; the randomly arrayed prisms are probably acicular deuteric amphibole. X-ray analysis (Appendix A) indicates that some of the larger patches are composed of Na-saturated montmorillonite (trioctahedral; [001] peak near $7^{\circ} 2 \theta$ ), with traces of chlorite, mica, and amphibole. The chlorite and amphibole are probably relics of the deuterically altered late interstitial residuum.

Accessory pyrite is present as scattered grains and as clusters of euhedral cubes, both in the interstitial montmorillonite (where the largest clusters occur), and among the plagioclase and pyroxene. Total rock X-ray analysis (Appendix A) indicates that $\mathrm{K}$-feldspar is present in trace amounts. No recognizable deep green patches or veins of celadonite were seen megascopically or under the binocular microscope. The nature and origin of the mica detected in the X-ray patterns are unknown; the mica may be diagenetic celadonite or primary biotite. 
No veins or joints were observed. Calcite was seen only in one tiny interstitial patch. Apparently the lower part of this hole penetrated a mechanically intact basalt that had suffered none of the tectonic effects that might attend the spreading process at a ridge crest (compare Hole 165A).

The larger montmorillonite patches contain hexagonal ilmenite plates which are readily seen under a binocular microscope. In some cases the ilmenite grains are seen to be clusters of parallel, dendritic plates; in thin section these would appear as highly skeletal dendrites where sectioned at a high angle to the plates.

17-170-16-2, 61-70 cm: This specimen is a brown-gray, coarsegrained, nonvesicular, altered, aphyric basalt. No megascopically visible calcite, joints or veins except for one short (about $1 \mathrm{~cm}$ ), irregular calcite vein. The texture is diabasic intersertal. Most pyroxene and all interstitial residuum are altered to montmorillonite, so the texture may originally have been diabasic intergranular. No pseudomorphs after olivine were seen. In general, the rock is very similar to $17-170-16-2,144-147 \mathrm{~cm}$ (see the description of that specimen for more textural information). Moderately colored pyroxene and prominent accessory amounts of biotite are present and may reflect alkaline affinities of this rock

\begin{tabular}{|c|c|c|}
\hline $\begin{array}{c}\text { Component } \\
(\mathrm{min} / \mathrm{max} \text { size }-\mathrm{mm})\end{array}$ & $\begin{array}{l}\text { Average } \\
\text { Size }(\mathrm{mm})\end{array}$ & $\begin{array}{l}\text { Volume } \\
(\%)\end{array}$ \\
\hline $\begin{array}{l}\text { Plagioclase }(+ \text { secondary montmoril- } \\
\quad \text { lonite and K-feldspar) }{ }^{\mathrm{a}}\end{array}$ & & 46.3 \\
\hline Pyroxene ${ }^{b}$ & & 3.0 \\
\hline Opaque grains ${ }^{\mathrm{c}}$ & & 5.4 \\
\hline Montmorillonite & & 41.7 \\
\hline Biotite + chlorite (and celadonite?) & & 2.7 \\
\hline Amphibole $\mathrm{e}^{\mathrm{e}}$ & & 0.8 \\
\hline Calcite & & 0.1 \\
\hline Apatite & & Trace \\
\hline
\end{tabular}

${ }^{\mathrm{a}}$ The $\mathrm{K}$-feldspar shows up prominently in total rock X-ray patterns (Appendix A).

${ }^{b}$ Light brown to light violet remanents.

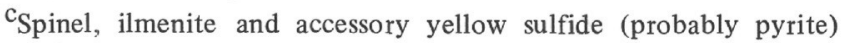
grains.

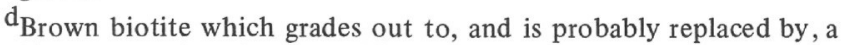
blue green mineral. Also, a blue green mineral unrelated to biotite; in some, but not all, cases this mineral is associated with opaque grains; it is probably the chlorite seen in X-ray patterns (Appendix A) but it may also include some celadonite. It so, the chlorite is probably a deuteric product after biotite and titanomagnetite; celadonite, if present, is probably a diagenetic product after biotite.

${ }^{\text {e}}$ Probably a deuteric alteration product of the late interstitial residuum (see Plate 5, Figure 2).

17-170-16-2, 86-92 cm: Specimen is a brown gray, coarsegrained, nonvesicular basalt. It is altered, but less than the basalt above. There are few distinct patches of pure montmorillonite. Pyrite, which is highly tarnished, is much rarer than in the basalt above; a few orange brown $\mathrm{Fe}$ oxide grains may be oxidized pyrite, but these too are very sparse. The sympathetic variation in the abundances of montmorillonite and pyrite suggests that the pyrite is not of primary or deuteric origin in its present form, but is formed diagenetically due to an influx of $\mathrm{S}$ along with $\mathrm{H}_{2} \mathrm{O}$ that went to form montmorillonite, or by diagenetic recrystallization and concentration of originally finely dispersed primary or deuteric sulfide. No veins or joints are present, but the lower half of the specimen is specked by sub-millimeter patches of calcite which apparently are not amygdules. The coarse grain size and the lack of near-contact chill features indicate that the appearance of calcite in this specimen is not related to proximity to a contact. The tendency to form this calcite indicates that the general absence of calcite veins and amygdules in the overlying specimens is due, not to lack of available $\mathrm{Ca}$ and $\mathrm{CO}_{2}$, but to lack of the vesicles, joints, and other megascopic pore spaces in which calcite tends to be deposited. Mobility of $\mathrm{Ca}$ is indicated by the generally low $\mathrm{CaO}$ contents of rocks from this basalt unit (Table 1). The Ca was lost mainly from pyroxene and almost all of it that was mobilized evidently diffused entirely out of the rock.

17-170-16-2, 104-118 cm: Very much like 17-170-16-2, 86-92 $\mathrm{cm}$, but even less altered. There are virtually no discrete patches of montmorillonite. Both pyrite, which is highly tarnished, and orange brown Fe oxide are very rare, even more so than in $16-2,86-92 \mathrm{~cm}$. These facts again suggest a covariance of montmorillonite and pyrite, which, in turn, indicates that the pyrite is of diagenetic origin. Calcite specks are larger (up to $1 \mathrm{~mm}$ or slightly larger) and more numerous than in $16-2,86-92 \mathrm{~cm}$ and are distributed throughout the entire length of the specimen. Again, there are no near-contact features, and the calcite specks do not appear to be amygdules.

Many ilmenite grains are clearly composed of dendritic groups of parallel plates.

The next lower specimen, 16-2, 135-150 cm, lacks the calcite specks but contains some discrete patches of montmorillonite, less than in specimens higher in this basalt unit, but comparable in number to the calcite patches in the present specimen. The calcite and montmorillonite play comparable textural roles, a fact which suggests that they represent different types of alteration of the same material. In specimen $16-2,135-150 \mathrm{~cm}$, only six pyrite grains were observed by binocular microscopic examination, and of these only one was tarnished. No orange brown $\mathrm{Fe}$ oxide grains were observed. The data suggest that Specimen 16-2, 104-118 cm and the lower half of $16-2,86-92 \mathrm{~cm}$ represent a highly permeable zone in the interior of the flow or sill to which there was a fairly free access of oxygen and $\mathrm{CO}_{2}$. Earlier formed pyrite was partially to completely oxidized in this zone. Some parts of the rock, such as the late interstitial residua and possibly vesicles (if any were present) which elsewhere, both above and blow, were replaced by or filled with montmorillonite, were in this permeable zone replaced by or filled with calcite.

This zone was avoided in selecting samples for chemical analysis, but might be of interest for future, comparative studies.

17-170-16-2, 144-147 cm: Specimen is a brown-gray, coarsegrained, nonvesicular, aphyric basalt. It is less altered than 16-2, $61-70 \mathrm{~cm}$, and contains fewer discrete montmorillonite patches. No megascopic joints, veins, amygdules, or calcite patches were observed. The texture is diabasic and varies locally from intergranular to intersertal. Local intergranularity is more apparent than in 16-2, 61-70 cm and higher specimens because of better preservation of pyroxene (Plate 5, Figure 3). No definite pseudomorphs after olivine were identified. Grain size is considerably larger than in 16-1, 24-37 cm, and about the same as in 16-2, 61-70 cm (Plate 5, Figures 1 and 3). Amphibole is more abundant than in higher samples, a fact which suggests a deuteric origin and an increase of deuteric minerals from the upper surface into the interior of the flow or sill.

\begin{tabular}{ccc}
\hline $\begin{array}{c}\text { Component } \\
(\mathrm{min} / \mathrm{max} \text { size }-\mathrm{mm})\end{array}$ & $\begin{array}{c}\text { Average } \\
\text { Size }(\mathrm{mm})\end{array}$ & $\begin{array}{c}\text { Volume } \\
(\%)\end{array}$ \\
\hline $\begin{array}{c}\text { Plagioclase }(+ \text { secondary } \\
\text { montmorillonite })^{\mathrm{a}}\end{array}$ & $1.3 \times 0.22$ & 53.2 \\
$(0.25 \times 0.05 / 3.7 \times 0.35)$ & &
\end{tabular}

Pyroxene + montmorillonite unequivocally derived from pyroxene ${ }^{b}$

$(0.4 \times 0.25 / 2.1 \times 0.8)$

Opaque grains $\mathrm{c}$

elongate $(0.3 \times 0.02 / 3.35 \times 0.03)$ 
Montmorillonite (may include pseudomorphs after olivine) ${ }^{\mathrm{d}}$

Brown biotite + chlorite and celadonite?d (length) $\mathrm{e}^{\mathrm{d}}$

$(0.02 / 0.08)$

Amphibole $\mathrm{f}^{\mathrm{f}}$

Calcite

Trace

Aptite

${ }^{a}$ No definite $\mathrm{K}$-feldspar was detected by total rock X-ray analysis (Appendix A) or seen in thin section.

b $_{\text {See Plate } 5, \text { Figure } 3 .}$

${ }^{{ }^{C}}$-ray data (Appendix A) indicate moderately titaniferous titanomagnetite and ilmenite; no anatase was detected; this assemblage is probably the primary igneous assemblage and indicates a moderately oxidized magma. Survival of the primary assemblage only 1.5 meters below the maghemite plus anatase assemblage in 17-170-16-1, 17-24 cm and the magnetite-anatase-ilmenite assemblage in $17-170-16-1,24-37 \mathrm{~cm}$ indicates that the diagenetic oxidation "front", though somewhat spread out, is nonetheless fairly sharp. Pyrite is present, but very minor.

$\mathrm{d}_{\text {Within the montmorillonite there are discrete books or large flakes }}$ which are dirty with inclusions; they may be relics of single-crystal iddingsites which had replaced primary olivine, or, much less likely, altered biotite. Rare intersertal patches have subhedral outlines and may enclose biotite flakes or tiny calcite patches (component 7); these are the only direct suggestions of pseudomorphs after olivine, but they may equally well be altered biotite. The montmorillonite may enclose some of the chlorite detected in the total rock X-ray pattern (Appendix A).

${ }^{\mathrm{e}}$ The biotite in some cases is concentrated around equant opaque grains which are probably titanomagnetite. Chlorite (or celadonite?) is minor.

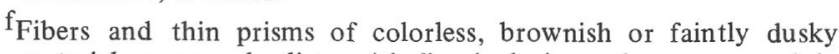
material, commonly dirty with fine inclusions; they occur mainly as spindles in the groundmass montmorillonite, but they may also be clustered on the surfaces of pyroxene grains. They were confirmed as amphibole by X-ray analysis (Appendix A).

\section{SITE 171}

Site 171 (Horizon Guyot) penetrated mainly calcareous rocks. Between 287 and 345 meters there were calcareous and volcanic rocks; the latter include pillowed extrusives of olivine basalt, described below, and a variety of volcanic sediments.

The highest of these sediments (of Santonian age) are a series of distinctly bedded sandstones and siltstones of overall olive colors. In detail, the beds have a "salt-and-pepper" aspect due to silt, sand, and some fine pebbles of black, brown, white, green, etc., palagonite, basalt, glass, glauconite, and foraminifers. There is a matrix of nannofossils and montmorillonite and a calcite cement. Analcime and clinoptilolite are abundant in much of the section. Site 171 is in a small depression on top of the guyot. Sediments were probably formed into the depression by the reworking of hyaloclastite fragments from nearby basaltic vents, along with pelagic and benthic carbonates. Siltstone is more common than sandstone in the lower part of these beds; they are laminated and grade into bluish gray waxy claystones. The sandstone immediately above the pillowed basalt flow at 334 meters is hyaloclastite in place on the igneous rock.

The pillowed flow lies on a conglomerate containing pebbles and small cobbles of limestone and basalt. The limestone probably formed in a lagoon, and the highly vesicular basalt pebbles, rounded and soft from deep weathering, probably were eroded from a subaerial eruption. This deposit may have been a talus of shallowwater detritus, dislodged from a higher part of the guyot during the mid-Cretaceous volcanic event.

Core 28 probably records the beginning of that volcanism. It is a coarse hyaloclastite, of palagonite, frothy glass, clays, and zeolites, colored various hues of yellow as well as gray, green, and orange. It closely resembles the original hyaloclastite from the type locality in Sicily.

Recovery of the lowest 130 meters was so poor that it is not known if the section includes volcanic sediments.

Igneous volcanic rocks were recovered at two levels, namely, in Cores 26 and 27 and at the bottom of the hole $(479 \mathrm{~m})$. The higher volcanic rocks include a number of independent units whose boundaries, indicated by glassy selvages and sedimentary intercalations, lie in Core 26 (Sample 26-CC), at $27-1,39 \mathrm{~cm}$, at $27-1,127$ $\mathrm{cm}$, and at $27-3,109 \mathrm{~cm}$. The steep to moderate dips of the selvages indicate pillows rather than flows. The lowest pillow is more than 2.78 meters thick. The interpillow sediments are detrital limestones with abundant clasts of basalt, altered glass and echinoderm(?) plates. Below the lowest pillow there are possibly plant fragments.

The pillowed igneous rocks are porphyritic olivine basalt with phenocrysts and microphenocrysts of olivine alone or olivine plus minor plagioclase. All olivine is now entirely replaced by montmorillonite pseudomorphs. The rocks grade rapidly inward from glass to quenched variolitic basalt, to intergranular or subophitic, mediumgrained basalt. Montmorillonite-filled ovoid patches were originally vesicles or chlorophaeite patches. The interpillow detrital limestones, with relatively coarse igneous and skeletal debris and possible plant fragments, suggest shallow-water emplacement of the basalts. This is in accord with inferences from the underlying conglomerate and from the more extensive and definitive results of other studies of the Mid-Pacific Mountains (e.g., Hamilton, 1956). In view of this conclusion, the montmorillonite patches are interpreted as vesicle fillings rather than altered chlorophaeite in most cases (contrast the similar patches in the rocks from Site 167). In the thickest pillow, the sizes and abundances of the amygdules reach a maximum in Specimen $27-2,75-86 \mathrm{~cm}$ and a secondary maximum in $27-3,70-80 \mathrm{~cm}$. They are almost absent in the upper and lower 10 to $15 \mathrm{~cm}$ of the pillow and on either side of some calcite-filled veins. These veins may represent primary shrinkage cracks along which chilled, nonvesicular basalt was formed. The apparent variability and possible zoning in size and abundance of vesicels are features commonly found in pillows.

Olivine microphenocrysts in the chilled selvages indicate that the magma was erupted with suspended crystals. The larger average size and greater abundance of olivine microphenocrysts in the pillow interiors indicate continued crystallization of olivine after eruption, and the apparent absence of groundmass olivine indicates cessation of olivine crystallization before final consolidation, as in typical abyssal basalts of mid-ocean ridges. A relatively high concentration of olivine in the lower part of the thickest pillow indicates that it crystallized slowly enough to allow some settling and accumulation of olivine.

The main opaque minerals are a spinel plus minor or trace amounts of ilmenite. The spinel varies from nearly pure magnetite to moderately titaniferous titanomagnetite. Evidently the magma was, in general, fairly oxidized, and the actual oxygen activity varied locally between, and perhaps within, pillows and probably as a function of time during consolidation. This is expectable in a near-surface magma from which there is active evolution and migration of a gas phase. An early spinel, probably picotite, appears mainly as inclusions in olivine. The picotite varies somewhat in composition as indicated by its variable unit cell edge (Appendix A and Table 5).

The pillowed basalt is generally highly altered. Despite this alteration, some sideromelane survives in the lower selvage of the thickest pillow, and orange brown and red palagonite, of types that form on interaction of exposed basic glass directly with seawater (i.e., before burial), are also present in the lower selvage. For reasons unknown, the effects of diagenesis, which are prominently developed in selvages of higher specimens and in the interiors of the pillows, are weakly developed in this lowest selvage.

The main diagenetic effects include almost complete replacement of pyroxene by montmorillonite; complete replacement of olivine by montmorillonite and minor calcite; minor replacement of plagioclase by montmorillonite; complete local replacement of the groundmass by montmorillonite and minor calcite; filling of veins by calcite and minor montmorillonite; filling of vesicles by montmorillonite and minor calcite; and formation of large, irregular patches of calcite or mixed calcite plus montmorillonite (Plate 6, 
Figure 2). The irregular patches may be isolated or connected to veins. There is no direct evidence that they are vesicles or related somehow to vesicles; they are in some cases elongated and may be related to cracks or incipient cracks. Their formation may have involved replacement, perhaps of the groundmass or of chlorophaeite.

Almost all montmorillonite, whether it fills vesicles or replaces olivine, groundmass, or perhaps chlorophaeite, is brown, if it was once present, and, except in pseudomorphs after olivine, it forms round to ovoid or irregular ovoid masses with both radial and concentric structures. It is extremely difficult to distinguish the products of the different possible modes of origin except perhaps by the sizes and shapes of the masses and their relations to other components of the rocks. Various cases are shown in Plate 5, Figures 4, 5, 6, 7, 8 and in Plate 6, Figure 1. The pseudomorphs after olivine are typically subhedral to euhedral, have a mesh structure, and commonly contain calcite and inclusions of early spinel.

Minor products of diagenesis include pyrite grains and clusters of grains in many of the irregular patches of calcite and of calcite plus montmorillonite; celadonite patches or amygdules in the upper part of the thickest pillow; montmorillonite and celadonite pseudomorphs after glass clasts in the interpillow detrital limestones; brown alteration products, including montmorillonite(?) and $\mathrm{Fe}$ oxide, after enchinoderm(?) plates in the interpillow detrital limestones; and varied products of alteration of glass selvages of pillows. Rare phillipsite in the upper selvage of the thickest pillow probably formed during early diagenesis. Later, the various glass layers were altered to poorly crystallized montmorillonite, to calcite plus poorly crystallized montmorillonite, or to abundant calcite plus poorly crystallized, mixed-layer mica-montmorillonite. The mixedlayer mica-montmorillonite is found only at the top of the thickest pillow, where it is associated with highly calcitized glass. A similarly calcitized glass layer at the bottom of that same pillow lacks the mica-bearing phase. The poor crystallinity of the layer lattice silicates appears to be typical of such minerals where they form as products of marine diagenesis of basic glass.

In general, $\mathrm{K}$ metasomatism did not produce discrete $\mathrm{K}$-rich phases except in the uppermost parts of the thickest pillow and in the immediately overlying interpillow detrital limestones. In the pillow, celadonite patches formed by filling vesicles and/or by replacement of late interstitial residuum; and mixed-layer micamontmorillonite formed in highly calcitized glass. In the limestones, relatively large glass clasts, and, perhaps, some very finely divided and dispersed glass in the matrix, were altered to celadonite, probably accompanied by some montmorillonite. Elsewhere, no mica was found, and in no case was K-feldspar identified. The celadonite, especially that which replaces glass clasts in the detrital limestone, is peculiar in expanding very slightly on exposure to ethylene glycol vapor. This fact indicates the presence of minor interlayered montmorillonite. The celadonite is thus related to the mixed-layer mica-montmorillonite, but has the green or blue green color typical of celadonite in contrast to the pale gray or buff color of the altered glass in which the mixed-layer phase is located.

The trace element chemistry (Table 1; Figures 1, 2, and 3) indicates that the pillowed basalts are similar to ocean island tholeiites and to ocean ridge basalts. In view of the intense alteration, including extensive destruction of clinopyroxene and possible loss of trace elements, however, it is probable that the magmas were ocean island tholeiitic or even alkaline. Yet, despite the intense alteration, the great increase of $\mathrm{K}$ commonly attendant on seawater and diagenetic alteration is not in evidence. The reasons for the low $\mathrm{K}$ and restricted occurrence of K-rich phases are not known. The main reason is probably a limited supply of $\mathrm{K}$. The $\mathrm{K}_{2} \mathrm{O}$ values of the rocks $(0.20$ and 0.34 weight \%; Table 1$)$ are somewhat higher than those of typical ocean ridge basalts, but not so high as those of many Hawaiian tholeiites. Montmorillonite extracted mainly from large amygdules in $17-171-27-2,75-86 \mathrm{~cm}$, located in the interior of the thickest pillow, similarly has a low $\mathrm{K}_{2} \mathrm{O}$ content $(0.24 \%$; to be reported with other montmorillonite analyses elsewhere) despite the probability that the montmorillonite in altered oceanic basalts carries the secondary $\mathrm{K}$ of such rocks in surface and interlayer cation positions, (if one may judge from the general direct correlation between $\mathrm{K}_{2} \mathrm{O}$ and montmorillonite in them). The reasons for the poverty in $\mathrm{K}$ in the present case may be as follows. Montmorillonite-rich altered basalts very likely act as effective ion-exchange membranes for those cations selectively fixed in the exchangeable surface and interlayer cations sites of swelling clays. The generally small amounts of available $\mathrm{K}$ are fixed at and near those free surfaces in contact with freely flowing or diffusing pore fluids, and the relatively tight rock volumes bounded by those surfaces receive little if any secondary $\mathrm{K}$. This suggestion can be tested in situations like that at Site 171 if cores are recovered sufficiently intact to allow discrimination of natural fractures and the unfractured volumes of rock that they delineate. The test must be applied to a homogeneous crystalline rock mass; glassy or quenched contacts cannot be compared with crystalline interiors of flows and pillows because the rocks will alter and take up $\mathrm{K}$ differentially as a result of their different physical states. Experience with Leg 17 rocks suggests that sills emplaced at sites well removed from a spreading center may offer the best material with which to carry out the test, and the analyses of the lower igneous unit at Site 170 (Table 1) may in fact constitute such a test. The sill is largely unfractured and the monotonic decrease of $\mathrm{K}$ with depth from the upper surface appears to confirm the predicted result. The deepest analyzed sample $(17-170-16-2,144-147 \mathrm{~cm})$ has only $0.61 \% \mathrm{~K}_{2} \mathrm{O}$, which may approximate the initial $\mathrm{K}_{2} \mathrm{O}$ content of the magma.

The available $\mathrm{K}$ at Site 171 , despite its small amount, was fixed in $\mathrm{K}$-rich phases locally. One of these, celadonite, is probably of diagenetic origin, to judge from the situations at other sites drilled during Leg 17. The mixed-layer mica-montmorillonite is unique. It has never before been reported in an oceanic rock from Leg 17 or elsewhere, and, while it is probably of diagenetic origin, this conclusion is not certain. It could conceivably be of hydrothermal origin. Trace amounts of chlorite occur in the pillowed basalt at Site 171 , and some of the chlorite occurs in amygdules in an altered glassy selvage, where it is almost certainly not of deuteric origin. It suggests mildly elevated temperatures of short duration. Apparently, a brief post-magmatic episode of mildly elevated temperatures and hydrothermal alteration occurred, and the mixed-layer micamontmorillonite could have formed either concurrently with chlorite at that time, or diagenetically at much lower temperatures.

The deepest rock recovered at Site 171 is olivine basalt porphyry with stronger alkaline affinities than those of the overlying pillow basalts. Olivine crystallization continued into the groundmass. Again, the olivine is entirely replaced by montmorillonite pseudomorphs. The $\mathrm{K}_{2} \mathrm{O}$ content $(1.07 \%)$ is, in view of the small amount of secondary $\mathrm{K}$ inferred above, probably primary and is consistent with the trace element data (Table 1; Figures 1, 2, and 3) which indicate affinities with ocean island tholeiites. In view of possible trace element loss during the intense diagenetic alteration, the magma may originally have been distinctly alkaline.

Relict, late-formed, well-crystallized, micaceous iddingsite forms the outermost zones of, and lines cracks in, olivine phenocrysts and totally constitutes the groundmass olivine (Plate 6, Figure 3). The iddingsite indicates strongly oxidizing conditions in the magma, in accord with indications from the opaque mineral assemblage which comprises ilmenite and maghemite. The absence or anatase indicates that the primary spinel phase must have been poor in, or devoid of, $\mathrm{Ti}$, and was, therefore, essentially pure magnetite or a member of the magnetite-maghemite solid solution series. The highly oxidizing magmatic conditions may have stemmed in part from subaerial eruption. The overlying marine sediments suggest that the lava may then have entered the sea at a shore line. The virtual absence of vesicles and amygdules in this rock might be a result of thorough degassing during the subaerial stage. Hamilton (1956) describes abundant olivine basalt porphyries with iddingsite from Horizon Guyot and other parts of the Mid-Pacific Mountains. Those rocks, too, may in part have been erupted subaerially.

The trace amounts of chlorite in the rock at the bottom of the hole could be deuteric or a product of later hydrothermal alteration. The fine grain size indicates a moderately chilled rock. This fact, together with evidence for degassing of the laval, indicates that deuteric alteration is relatively unlikely, and favors later hydrothermal alteration. It may be related to the same episode of hydrothermal alteration which produced chlorite in the pillowed basalts higher in this hole. 
Site 171 is located in a seamount chain, the Mid-Pacific Mountains, which is of a large size, comparable to that of the Hawaiian chain. Extrapolating from Hawaiian experience, we expect alkalic basalts or ocean island tholeiites like the rock at the bottom of the hole, but we do not expect rocks, such as the pillowed basalts intercalated in the overlying sediment section, which resemble ocean ridge basalts (Table 1; Figures 1, 2, and 3). As discussed above, the semblances may result from loss of trace elements during diagenetic alteration. However, if the rocks are in fact ocean ridge basalts, we might infer from them a spreading center of some sort, the most likely candidate for which would be, on the basis of present knowledge, a "leaky" ancestral Molokai Fracture Zone.

The general conditions of diagenesis at Site 171 are comparable to those at Site 167 on Magellan Rise, and apparently involve a high activity of $\mathrm{CO}_{2}$ related to the carbonate-rich sediment section. Horizon Guyot, on which Site 171 is located, is a topographic high within which circulation of pore fluids would be favored even more so than at Site 167. At both sites there is evidence for postmagmatic hydrothermal activity which, at Site 167, appears to be related to tectonic breccia zones. Such tectonic and hydrothermal activity is probably a normal accompaniment of the construction and sporadic gravity collapse of a large seamount. At Site 171, in addition, there are undoubtedly influences from movements on the Molokai Fracture Zone. Some rocks at both sites have prominent montmorillonite patches of uncertain origin. At Site 167, they were tentatively interpreted as altered chlorophaeite patches, at Site 171, as amygdules. They may be of the same origin at both sites and it remains for future work to decide which, if either, of these explanations is correct.

The following petrographic descriptions are based on binocular microscopic and X-ray examinations, and, in the four cases where point count modes are given, on thin section examination as well. The thickest pillow was examined in detail.

\section{Petrography}

17-171-26-CC: Sample is a dark brownish gray, fine- to mediumgrained, amygdaloidal porphyritic basalt cut by numerous calcite veins from which minor bulbous protrusions emanate. One irregular joint is filled with montmorillonite, the color of which varies from brown to green along the length of the vein. Round to irregular patches of calcite are prominent and uncommon clusters of holes have the same sizes and shapes as the calcite patches. Equally prominent are green montmorillonite patches of two types. The more common type is irregular or subhedral to euhedral, light grayish green, and either homogeneous or laced by a relict mesh structure (Plate 5, Figure 4). This type may include some altered late interstitial residuum, but is mainly altered olivine, the abundance of which suggests an olivine cumulate zone (compare 17-171-27-3, 61-70 $\mathrm{cm}$ and deeper samples). The second, and much less common type, is smoothly ovoid, dark green, and micronodular to flaky. This type has narrow, well-defined rims in some cases (Plate 5, Figure 4). It appears to represent amygdules rather than altered chlorophaeite or altered late interstitial residuum. In the descriptions of deeper samples, montmorillonite patches are called either pseudomorphs after olivine or amygdules by comparison with these two types, respectively.

\begin{tabular}{lcc}
\hline $\begin{array}{c}\text { Component } \\
\left(\mathrm{min} / \mathrm{max}^{2} \mathrm{mize}-\mathrm{mm}\right)\end{array}$ & $\begin{array}{c}\text { Average } \\
\text { Size }(\mathrm{mm})\end{array}$ & $\begin{array}{c}\text { Volume } \\
(\%)\end{array}$ \\
\hline $\begin{array}{l}\text { Plagioclase microphenocrysts } \\
(0.55 \times 0.1 / 0.8 \times 0.3)\end{array}$ & 1.2 \\
$\begin{array}{l}\text { Pseudomorphs of olivine } \\
\text { microphenocrysts }^{\mathrm{a}}\end{array}$ & $0.6 \times 0.45$ & \\
montmorillonite $^{\mathrm{b}}$ & & \\
calcite $^{\mathrm{b}}$ & & 9.7 \\
opaque inclusions $^{\mathrm{b}}$ & & 0.5 \\
$(0.02 / 0.03)$ & & \\
& &
\end{tabular}

Groundmass plagioclase

$(0.08 \times 0.01 / 0.4 \times 0.08)$

$0.2 \times 0.03$

Groundmass $^{\mathrm{c}}$

Montmorillonite amygdules ${ }^{\mathrm{d}}$

0.15

$(0.07 / 0.65)$ ${ }^{a}$ See Plate 5, Figure 4
${ }^{b}$ They enclose trace amounts of equant euhedral opaque grains, the
presence of which is one of the best ways to distinguish montmoril-
lonite pseudomorphs after olivine from montmorillonite amygdules
in doubtful cases. X-ray analysis (Appendix A) indicates that the
inclusions are probably picotite with a fairly broad compositional
range (contrast $17-171-27-3,80-92 \mathrm{~cm}$ ).

${ }^{\mathrm{c}}$ Dense, dark, very fine-grained, almost opaque; it includes most opaque minerals in the rock. The main components are probably montmorillonite, pyroxene, and opaque minerals. X-ray analysis (Appendix A) of the separated opaque minerals indicates moderately titaniferous titanomagnetite and traces of ilmenite and anatase. This must be nearly the primary assemblage, and indicates a fairly oxidized magma.

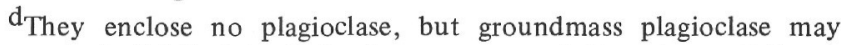
project slightly into their edges or surround them tangentially, as if they were once drusy holes (Plate 5, Figure 4).

${ }^{\mathrm{e}}$ The thin section was cut to avoid a large concentration of these veins and patches.

17-171-27-1, 39-45 cm: Chilled flow top or pillow margin. It grades over a distance of $4 \mathrm{~cm}$ from slightly greenish gray altered glass, through a light grayish buff spherulitic zone, then a medium gray brown variolitic(?) zone, to very fine-grained basalt with plagioclase microphenocrysts. Abundant veins and patches of calcite are present. In the altered glass and spherulite zone, the veins have selvages of phillipsite. The calcite patches occur mainly and rare montmorillonite ovoids solely in the relatively coarsely crystalline interior. All the ovoids appear to be amygdules. The absence of recognizable pseudomorphs after olivine in this sample suggests that if olivine was ever present in the magma it sank below the level of this specimen.

17-171-27-1, 65-70 cm: Specimen is a medium-grained, dark brown gray, porphyritic basalt with abundant ovoid and irregular patches of calcite, minor calcite veins, and very minor irregular holes. Montmorillonite ovoids are of the same two types and in roughly the same proportions as in $17-171-26-\mathrm{CC}$, but are very minor. The total rock X-ray pattern (Appendix A) indicates a primary opaque mineral assemblage of ilmenite and a titanomagnetite not especially rich in $\mathrm{Ti}$.

17-171-27-1, 98-108 cm: Specimen is a dark brown gray, microphyric basalt with abundant veins and irregular patches of calcite and minor empty holes. Abundant montmorillonite pseudomorphs after olivine suggest an olivine cumulate zone. Montmorillonite amygdules are absent. The calcite veins and patches may have discontinuous selvages of montmorillonite, but, for the most part, calcite and montmorillonite occur separately.

17-171-27-1, 127-133 cm: Specimen is a crack filling or interbed of altered, sandy, detrital limestone of variable thickness, generally 4 to $5 \mathrm{~cm}$, and dipping about $45^{\circ}$. It is flanked on both sides by altered glass masses which appear to be selvages of pillows.

The limestone is mainly calcite with igneous and skeletal clasts up to $2 \mathrm{~mm}$; the clasts are round to angular. The matrix is light to medium greenish gray, the color varying with the abundance of light green resinous material (montmorillonite?). Distinct purplish gray and light brown areas do not appear to be relics of diagenetically unaltered clastic limestone, nor are they clear-cut clasts. They may have been plastic masses of distinct sediment types which somehow fell or flowed into the interpillow void along with the sandy limestone matrix in which they are embedded. 
The main clasts are of two general types, namely, igneous and organic skeletal. The igneous clasts are angular to subrounded, variously colored (yellow to brown, and light to medium green), dense, microcrystalline, and homogeneous; crystalline igneous textures are never visible. These clasts probably represent original glass, palagonite, and highly altered palagonite. The more altered types of palagonite remained as, or became, amorphous or crystalline $\mathrm{Fe}$ oxides during diagenesis, whereas the less altered types changed diagenetically to montmorillonite and celadonite. The skeletal debris is less abundant than the igneous and is evidently composed solely of echinoderm(?) plates, singly or in small stacks. The plates, too, are altered, most commonly to orange or brown $\mathrm{Fe}$ oxide, less commonly to green or light greenish brown masses which probably include montmorillonite and possibly celadonite.

$\mathrm{X}$-ray analysis (Appendix A) of a mixture of light to medium green, soft, resinous, angular, altered glass clasts indicates montmorillonite, celadonite with minor interlayered montmorillonite, plagioclase, and possibly a trace of anatase. The plagioclase may be relict microlites in the altered glass or contamination from the sandy ooze.

The altered glass flanking the limestone has a blocky structure, has been extensively replaced by calcite, and contains minor ovoid to round, vesicles variably filled by montmorillonite and/or calcite. The individual "blocks" are rimmed by finely laminated material, which suggests that they were peripherally altered to colorlaminated palagonite before diagenesis.

17-171-27-1, 133-142 cm: Specimen is a light greenish gray sandy detrital limestone, as in 17-171-27-1, 127-133 cm; it is sharply bounded against a zonally altered selvage which includes layers and lenses of: (a) gray calcitized glass; (b) brown gray altered glass; (c) light gray to buff calcitized glass; (d) light to medium gray altered spherulitic(?) rock; (e) dark green rock of uncertain nature; and (f) finely crackled, almost calcite-free, medium gray altered glass. X-ray analysis (Appendix A) indicates that light gray translucent material in (b) is composed of plagioclase, calcite, and traces of poorly crystallized montmorillonite and mixed-layer mica-montmorillonite; that (c) is composed of calcite, plagioclase, and minor, poorly crystallized, mixed-layer mica-montmorillonite; that black ovoids and patches in (c) are composed of montmorillonite and a trace of chlorite; and that (f) is composed of plagioclase, poorly crystallized montmorillonite and a trace of calcite. Ovoid to irregular patches of uncertain origin, composed of montmorillonite or calcite, appear in most layers. Hollow, montmorillonite-lined vesicles appear only in (c) and (d). Two patches of Fe-stained phillipsite in layer (c) are the only diagenetic phillipsite seen in rocks from Leg 17 which does not occur as distinct veins.

The layers dip about $70^{\circ}$ and are probably the upper lateral selvage of a pillow.

The main rock below the altered glassy layers is dark brown gray, fine-grained, microphyric basalt without veins, but with abundant, large, highly irregular patches of calcite, and abundant, very small, irregular patches of light brown, Fe-stained calcite. The large patches may contain red or brown altered material of sort, possibly oxidized pyrite; no fresh pyrite was seen. Both large and small calcite patches may have partial or complete rims of dark green, resinous celadonite(?). Montmorillonite patches and ovoids are absent except for one cluster of amygdules. Moderately abundant, however, are color-zoned patches of celadonite (deep green rims, yellow cores). X-ray analysis (Appendix A) of one indicates celadonite with a trace of montmorillonite.

The absence of montmorillonite pseudomorphs after olivine indicates that, if olivine was ever present in the magma, it sank below the level of this specimen.

As noted in the discussion of the top of the sill at Site 170, celadonite may play the same textural and paragenetic roles as some types of montmorillonite. In the present case there is no evidence to indicate whether the celadonite formed directly or replaced earlier montmorillonite. However, the fact that some small, unreplaced ovoids and patches of montmorillonite coexist with the celadonite patches, both here and in the upper part of Specimen 17-171-27-2, $17-26 \mathrm{~cm}$ (see below), suggests that the celadonite did not form by replacement of montmorillonite, and that celadonite plus montmorillonite may be a stable assemblage under conditions of marine diagenesis in at least some cases.

17-171-27-2, 17-26 cm: Specimen is a dark brown gray, microphyric, fine-grained basalt. Abundant irregular, equant to highly elongate, light gray patches of calcite, some of them containing brown oxidized material and/or rimmed by dark green montmorillonite or celadonite. Many patches are so long and thin that they are properly veins, but their borders are still minutely irregular or have bulbous extensions, thus placing them more in the same category as the equant irregular patches than in that of sharp, parallel-walled veins of the joint-filling type. The minutely irregular borders suggest an origin, at least in part, by replacement of the host rock. Also present are a few ovoid to round amygdule-like calcite patches, with or without montmorillonite rims. There are also irregular color-zoned patches of celadonite(?). The celadonite(?) decreases notably downward and is virtually absent in the lower third of the specimen. Evidently there is a strong inward gradient of alteration products from the surface of the flow or pillow, and, insofar as celadonite is involved, the gradient is one of secondary addition of $\mathrm{K}$.

This specimen is essentially like the main interior part of $17-171-27-1,133-142 \mathrm{~cm}$ below the altered glassy selvage, except that minor montmorillonite amygdules are present in this specimen. The amygdules are apparently restricted to the interiors of flows or pillows. Here they have thin, dark green, resinous rims which look much like the celadonite(?) patches. The rims, like the celadonite(?) patches, diminish downward and are absent in the lower third of the specimen. An X-ray pattern (Appendix A) of a concentration of the rims shows no celadonite, only montmorillonite.

The absence of montmorillonite pseudomorphs after olivine indicates that, if olivine was ever present in the magma, it sank below the level of this specimen. The total rock X-ray pattern (Appendix A) includes ilmenite, and indicates, as in the overlying pillows, a fairly oxidized magma.

17-171-27-2, 75-86 cm: Specimen is a dark brown-gray, finegrained, highly altered basalt porphyry with abundant montmorillonite ovids (Plate 5, Figures 5, 6, and 7), abundant veins and patches of light gray calcite, and patches of mixed calcite and montmorillonite. Celadonite is absent, and there are no vesicles. Calcite from mixed calcite-montmorillonite patches contains 4.0 mole $\% \mathrm{MgCO}_{3}$, whereas calcite from the centers of large, pure calcite patches contains 2.5 mole $\% \mathrm{MgCO}_{3}$ (Appendix A).

The different calcite compositions can be explained in two ways. The paragenesis suggests early calcite and late montmorillonite, with much overlap. The early solutions thus may have been Mg-poor, the later ones, during the periods of simultaneous growth of montmorillonite and calcite, Mg-richer. Alternatively, as indicated by much evidence at this site and others (see especially the discussion of the veins in the upper part of the sill at Site 170), the filling of veins and "amygdules" may reflect local equilibrium controlled by diffusion rather than by free, bulk flow of fluids. Thus, calcite crystallizing with montmorillonite will contain much $\mathrm{Mg}$ (and possibly $\mathrm{Fe}$ ), whereas calcite crystallizing alone will be relatively pure. Where vugs in otherwise pure calcite patches are lined or filled by montmorillonite, this explanation seems to imply improbably large local gradients, both of physical conditions and of concentrations of mobile ions. A change of conditions with time seems inescapable, whether such change is the sole or merely an ancillary cause of the different calcite compositions.

The only apparent exception to possible local chemical control of calcite composition was found in 17-167-94-3, 78-84 cm, where calcite masses embedded in a large ovoid of montmorillonite have essentailly constant composition (Appendix A and Table 6). This exists despite the fact that some are rich in inclusions (of unknown mineralogy, but presumably montmorillonite), whereas others are essentially free of them. insofar as one can judge from color and general appearance.

Megascopically the montmorillonite ovoids and patches constitute about $5 \%$ of the rock. In thin section, however, the criteria for distinguishing them from the groundmass were such that many small patches were classed with the larger ones and they collectively 
from more than one-quarter of the rock. Almost all pyroxene is altered, and the plagioclase, unlike that at other sites, is also extensively altered to montmorillonite. This rock is essentially the chilled equivalent of $17-171-27-3,80-92 \mathrm{~cm}$, and may be near the top of the same flow unit.

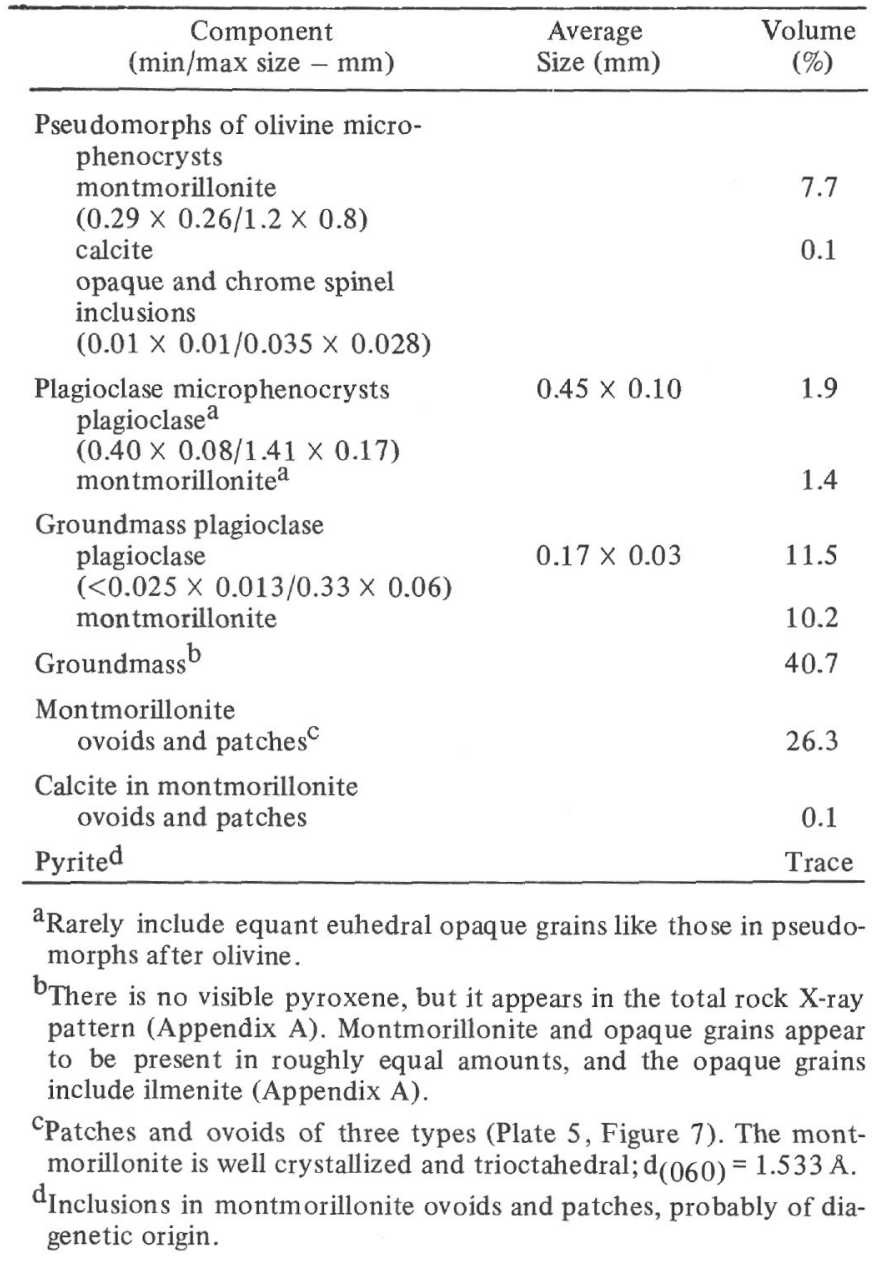

17-171-27-3, 19-27 $\mathrm{cm}$ : Specimen is a dark brown gray, fine- to medium-grained basalt, probably porphyritic. Several thin (less than $0.5 \mathrm{~mm}$ ) calcite veins appear to be fracture fillings. Calcite patches are all small (less than $1 \mathrm{~mm}$ ) and increase in abundance downward. Montmorillonite amygdules ( $3 \mathrm{~mm}$ or smaller) are moderately abundant and become smaller and concentrically zoned downward. The zoning is due to the appearance of gray green resinous rims with depth. The increased abundance of the rims with depth is the mirror image of their variation in 17-171-27-2, 17-26 cm, and large montmorillonite amygdules (the largest seen in this pillow) occur in between.

X-ray analysis (Appendix A) of a concentration of zoned amygdules from the bottom of the specimen indicates wellcrystallized montmorillonite (two types: Na-saturated and non-Nasaturated), without any mica or chlorite.

The marked changes from top to bottom in this specimen might initially suggest that it is near the edge of a pillow, but it is a meter above the bottom of the pillow (which appears in 17-171-27-3, $92-109 \mathrm{~cm}$ ) and probably more than a meter below the top (in $17-171-27-1,92-109 \mathrm{~cm}$ ) and probably more than a meter below the top (in 17-171-27-1, 133-142 cm). The changes with depth occur, therefore, in the middle of a pillow.
17-171-27-3, 27-37 cm: Specimen is a dark brown gray, mediumto coarse-grained basalt with a complex array of veins and patches of various sorts. Small (generally less than $1 \mathrm{~mm}$ diameter) calcite patches occur throughout except near some veins. Prominent elongate to equant protrusions emanate from one vein. Many of the thin vein-filled cracks probably formed after consolidation, but the more prominent veins with patch-free zones on either side may occupy primary shrinkage cracks flanked by chilled rock that was either degassed during chilling or froze before significant evolution of gas occurred.

Montmorillonite patches are varied and the main type is scattered randomly throughout the specimen without regard to the distribution of calcite patches. Some of this type have relict mesh structure and all may be pseudomorphs after olivine phenocrysts or glomerocrysts up to 3 or $4 \mathrm{~mm}$ in diameter, in which case this is an olivine-rich basalt. In view of the absence of pseudomorphs after olivine higher in the pillow or flow, the olivine here may in part represent a cumulate.

Amygdules are the second most common type of montmorillonite patch, and many have dark green rims. In general, the patches with dark green rims are most abundant in those areas near prominent calcite veins which are free of calcite patches and are uncommon or absent in areas of abundant calcite patches. X-ray analysis (Appendix A) of a concentration of dark green material indicates well-crystallized, Na-saturated montmorillonite plus a trace of mica. The mica has no interlayered montmorillonite. No chlorite is present. Rare orange brown grains occur in the host rock, in calcite veins and in montmorillonite patches. They may be oxidized pyrite. No fresh pyrite was seen.

17-171-27-3, 37-43 cm: Specimen is very much like 17-171-27-3, $27-37 \mathrm{~cm}$, with zones free of calcite patches on either side of both relatively flat and steeply dipping veins. One vein contains some orange brown, oxidized pyrite(?). In both this specimen and the overlying one, bulbous expansions are clearly associated with vertical or steeply dipping, rather than flat or gently dipping, veins. If the expansions represent former vesicles, the association suggests that either the distribution of vesicles controlled a set of late- or post-magmatic fractures, or an incipient fracture set somehow controlled the formation of amygdules. Both here and in other specimens, the expansions show a preferred association with vertical to steeply dipping veins.

Patches and ovoids are of the same types and distributions as in $17-171-27-2,27-37 \mathrm{~cm}$

17-171-27-3, 43-54 cm: Specimen is a dark brown gray, mediumto coarse-grained basalt with a moderate number of gently to steeply dipping, thin veins of calcite and less commonly of montmorillonite. Bulbous expansions of the calcite veins are very minor. Calcite patches are minor. The dominant patches are brown montmorillonite amygdules without rims of any sort. Less common are dark green, resinous patches and ovoids, and medium gray green intersertal areas.

The distribution of patches is not uniform. The brown montmorillonite patches are in the uppermost and lowermost parts of the specimen. The dark green patches are mainly in the middle of the specimen, just below a zone with most of the calcite patches. Just below the middle of the specimen a gently dipping $1 \mathrm{~mm}$ calcite vein is flanked by zones fairly free of any sort of patch or ovoid, and the intersertal gray green areas are best seen in the zone just below this vein, but they continue to the bottom of the specimen.

17-171-27-3, 54-61 cm: Specimen is a dark brown gray, mediumto coarse-grained basalt. Two thin calcite veins are present. Calcite patches are virtually absent and brown montmorillonite amygdules minor, whereas gray green pseudomorphs after cumulate olivine are abundant.

17-171-27-3, 61-70 cm: Specimen is a dark brown gray, mediumto coarse-grained basalt. There are minor, gently to steeply dipping, calcite veins with common bulbous expansions of calcite or of mixed calcite and montmorillonite. Otherwise, calcite patches are small and few. 
Medium gray green patches and somewhat fewer brown montmorillonite amygdules are moderately common. The gray green patches include both pseudomorphs after olivine and altered interstitial material. The patches resemble those in 17-171-26-CC, and both specimens appear to be from the lower parts of pillows that contain cumulate olivine.

17-171-27-3, 70-80 cm: Specimen is a dark brown gray, mediumto coarse-grained basalt. One flat-lying and one vertical vein (less than $1 \mathrm{~mm}$ thick) are present. They have numerous bulbous to elongate, flat or gently dipping, expansions of calcite or of mixed calcite plus montmorillonite. Gray green montmorillonite patches are mainly intersertal, but some appear to be pseudomorphs after olivine. Gray brown montmorillonite amygdules are ovoids to elongate, and the elongate ones are flat to gently dipping as if they represent the fillings of flow-oriented vesicles. The large ones are concentrated into flat or gently dipping zones aligned with elongate expansions which emanate from the vertical calcite vein, suggesting that the expansions were vesicles which again show a preferred association with vertical or steeply dipping veins.

17-171-27-3, 82-86 cm: Specimen is a dark brown gray, mediumto coarse-grained, intersertal to subophitic, highly altered porphyritic basalt. One almost vertical vein is a continuation of the one in $17-171-27-3,70-80 \mathrm{~cm}$. Small to tiny calcite patches, unrelated to any obvious vein, are abundant along the side of the specimen away from the vein. A relatively large, flat-lying, elongate, ovoid expansion from the vein in the upper part of the specimen is aligned with a pinch-and-swell series of flat-lying calcite or calcite plus montmorillonite ovoids. Irregular veins at the lower edge of the specimen include one with irregular calcite plus montmorillonite expansions which contain fresh pyrite. The pyrite suggests that the $\mathrm{Fe}$ in this specimen is in a relatively reduced state, and this is confirmed by the chemical analyses (Table 1), at least by comparison with the relatively oxidized $\mathrm{Fe}$ in 17-171-26-CC.

Gray green patches and ovoids are common and most of them appear to be, not interstitial, but mesh-structured pseudomorphs after olivine (Plate 5, Figure 8 and Plate 6, Figure 1).

Gray brown montmorillonite amygdules $(2 \mathrm{~mm}$ or less; Plate 5 , Figure 8 and Plate 6, Figure 1) are fairly common but not abundant at the top of the specimen. They fade rapidly downward and are rare or absent in the middle and lower parts. They are not aligned in any way with expansions on veins.

In the lower part of the specimen, on the other hand, are two large, gray brown montmorillonite parches. One is vertically elongate $(3 \times 0.5 \mathrm{~mm})$ and composed mostly of montmorillonite, a cluster of pyrite cubes in the lower part, and significant admixed calcite in the upper part (Plate 6, Figure 2). It may be a pipe amygdule. The other is an amoeboid patch of pure montmorillonite with its maximum dimension $(8 \mathrm{~mm})$ oriented vertically.

The thin section was taken from an area without veins and with very few calcite ovoids and patches. This rock is essentially a better crystallized equivalent of $17-171-27-2,75-86 \mathrm{~cm}$ and is probably a deeper part of the same flow unit or pillow. Montmorillonite of all sorts totals 59.2\%; the partition among intersertal material, pseudomorphs, and ovoids and patches is in part an estimate.

\begin{tabular}{lcc}
\hline \multicolumn{1}{c}{$\begin{array}{c}\text { Component } \\
(\mathrm{min} / \mathrm{max} \text { size }-\mathrm{mm})\end{array}$} & $\begin{array}{c}\text { Average } \\
\text { Size }(\mathrm{mm})\end{array}$ & $\begin{array}{c}\text { Volume } \\
(\%)\end{array}$ \\
\hline $\begin{array}{l}\text { Olivine microphenocrysts } \\
(\text { pseudomorphs })^{\mathrm{a}}\end{array}$ & $\sim 5.0$ \\
$(0.4 \times 0.4 / 1.3 \times 1.1)$ & & \\
$\begin{array}{l}\text { Plagioclase, groundmass and } \\
\text { microphenocrysts } \mathrm{b}\end{array}$ & $0.25 \times 0.03$ & 25.1 \\
$(0.1 \times 0.02 / 0.85 \times 0.1)$ & & \\
$\begin{array}{l}\text { Pyroxene remnants } \\
(0.15 \times 0.1 / 0.45 \times 0.35)\end{array}$ & & \\
& & \\
& &
\end{tabular}

Opaque minerals $\mathrm{d}$

elongate $(0.04 \times 0.004 /$

$0.08 \times 0.004)$

equant $(0.004 / 0.01)$

equant incl. in olivine

$(0.008 / 0.025)$

Intersertal montmorillonite $\mathrm{e}^{\mathrm{e}}$

Montmorillonite patches and ovoids $^{f}$

Calcite patches and ovoids $\mathrm{g}$

Pyrite $^{\text {h }}$

Trace

${ }^{\mathrm{a}}$ See Plate 5, Figure 8 and Plate 6, Figure 1.

blagioclase microphenocrysts, perhaps $2 \%$ of the rock, are less abundant than olivine microphenocrysts.

${ }^{c_{R}}$ Randomly oriented, intersertal, book-like aggregates of parallel light violet prisms interleaved with montmorillonite and opaque minerals; the aggregates are in some cases subophitic with respect to plagioclase. Evidently the late residual liquids in the rock were quite femic. Around large calcite and montmorillonite patches and ovoids there are relatively dark-looking, relatively coarse-grained, groundmass areas which are poor in plagioclase and intersertal montmorillonite and relatively rich in pyroxene and opaque minerals; there the pyroxene is fine-grained. Elsewhere it is usually very fine-grained. The parallel bladed texture is similar to that in $17-164-28-6,137 \mathrm{~cm}$. It is also like that of the interstitial components in Precambrian spinifex-textured ultramafic lavas and sills. Spinifex texture, which results from supercooling, is characterized by skeletal olivine, between the arms of which parallel pyroxene prisms occur in a matrix of chlorite and opaque minerals.

$\mathrm{d}_{\text {In }}$ the groundmass, the opaque minerals are equant to elongate, generally interleaved with pyroxene prisms. X-ray analysis (Appendix $\mathrm{A}$ and Table 5) indicates that the groundmass grains are nearly pure magnetite plus a trace of ilmenite. The inclusions in pseudomorphs after olivine are nonmagnetic, well-crystallized picotite (or possibly magnesiochromite) with a sharply defined composition (as estimated from the sharpness of X-ray peaks; contrast 17-171-26-CC).

${ }^{\text {e }}$ Probably replaces pyroxene and intersertal residuum.

f Locally so abundant that little "groundmass" (pyroxene, opaque minerals and intersertal montmorillonite) is evident. See Plate 5, Figure 8 and Plate 6, Figure 1.

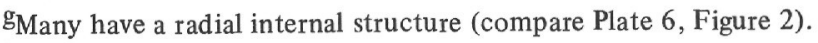

$\mathrm{h}_{\text {Traces in montmorillonite and calcite patches and ovoids. It is }}$ more common than in higher samples, probably due to less oxidation. One cluster of faceted crystals has a radial internal structure. The pyrite is probably of diagenetic origin.

17-171-27-3, 92-104 cm: Specimen is a dark brown-gray, fine-grained basalt; somewhat less brown than higher specimens, possibly due to finer grain size. The bottom edge is a glass-bearing selvage which dips about $15^{\circ}$ and which is the lower surface of the pillow or flow unit, the upper surface of which was intersected at 17-171-27-1, $131 \mathrm{~cm}$. Remnant sideromelane is coated on the lower side by sparry calcite and is altered to orange brown palagonite along joints and its lowermost surface. The sideromelane grades upward to dull gray altered or devitrified glass, and this in turn to an orange brown oxidized zone and then the main rock. The orange brown zone is probably spherulitic to finely variolitic and contains light greenish gray, Fe-stained pseudomorphs after olivine, glassy plagioclase microphenocrysts, small calcite patches, and very minor dark grayish green montmorillonite amygdules.

In the main rock, beside plagioclase microphenocrysts, there are gray green pseudomorphs after olivine which darken and increase in abundance and somewhat in size upward. Some of the olivine was glomeratic. The textural and abundance variations are consistent 
with indications from higher specimens that olivine settled and accumulated in this pillow or flow unit.

Calcite veins are few, thin ( $0.5 \mathrm{~mm}$ to hairline thickness), and mostly flat to gently dipping. The sides of the veins are even and parallel, not irregular; calcite or calcite plus montmorillonite expansions are present but minor. Elongate ones are oriented vertically and may have been pipe amygdules.

Two calcite plus montmorillonite patches contain fresh pyrite, in one case only $4 \mathrm{~cm}$ from the orange brown oxidized zone above the glass. A steep oxygen gradient or a sharp diffusion front is indicated.

Vesicles (1\% or less of the rock) are present as tiny, irregular, unfilled holes, and, in the upper part of the specimen, as round holes; some may have very thin, dark linings. Distinct montmorillonite amygdules appear only in the upper part of the specimen where the associated round, empty holes may have resulted from washing out of montmorillonite during sawing of the specimen.

17-171-27-3, 104-110 cm: The upper third of the specimen is basalt, the remainder is a sedimentary breccia. The contact, which dips about $40^{\circ}$ to $45^{\circ}$, is a continuation of the contact in 17-171-27-3, 92-104 cm, and indicates a maximum vertical extent of the continuously cored pillow or flow unit from $27-1,131 \mathrm{~cm}$ to 27-3, $109 \mathrm{~cm}$, hence, at least 2.78 meters.

The basalt and sediment are zoned, from top to bottom, as follows:

1) About $1 \mathrm{~cm}$ of brown gray basalt with abundant irregular calcite patches;

2) About 3 to $6 \mathrm{~mm}$ of orange brown oxidized basalt with a few small calcite patches and some plagioclase microphenocrysts; pseudomorphs after olivine, are smaller and more abundant in these first two zones than in the specimens above, possibly indicating a marginal zone which was chilled relatively early, but not until early small olivine phenocrysts had accumulated to the extent observed.

3) A 9 to $10 \mathrm{~mm}$ layer which grades from very fine-grained, chilled (but not visibly spherulitic), brown gray basalt above to sideromelane below; the sideromelane dominates and is rarely altered to deep red palagonite along cracks. Small pseudomorphs after olivine are finer (maximum size about $2.5 \mathrm{~mm}$, generally $1 \mathrm{~mm}$ or smaller) and much more abundant than in the interior of the pillow and probably represent a chilled remnant of crystals in the magma at the time of eruption. Montmorillonite amygdules in the sideromelane are rare.

4) A 1 to $2 \mathrm{~mm}$ deep red, fine palagonite breccia which is probably a hyaloclastite formed by crackling of the pillow surface on contact with seawater. Isolated, angular, red fragments of related origin appear also in layer (5) (see below).

5) A light tan, highly fractured, calcite-rich, soft, sectile layer, 2 to $3 \mathrm{~mm}$ thick, with isolated red angular fragments of the overlying layer (4). This is probably an altered hyaloclastite or reworked hyaloclastite layer. On the upper surface of this flow unit similar but grayer layers contain calcite and mixed-layer micamontmorillonite (layers (a) and (c) in 17-171-27-1, 133-142 cm). $\mathrm{X}$-ray analysis of this sample (Appendix A) indicates calcite (3.5 mole $\% \mathrm{MaCO}_{3}$ ), and traces of montmorillonite and anatase(?), but no mica. If the layer was originally glassy, calcitization is almost complete and only anatase(?) and montmorillonite remain to indicate the original material.

6) A $4 \mathrm{~cm}$ light to medium brown layer which varies from altered, glass-rich sediment to altered, granule-bearing, detrital limestone (a) Near the basalt the sediment is composed of echinoderm(?) plates, singly or in stacks, and altered glass fragments in a waxy, soft, sectile, massive, montmorillonitic, medium brown to light yellow brown matrix with rare lenticular calcite veins. This sediment grades rapidly into (b) light grayish brown, relatively clast-poor (essentially echinoderm(?)-plate-free) sediment. It is sharply bounded against (c) a clast-rich detrital limestone with a light gray calcite matrix; the clasts include exceptionally abundant echinoderm(?) plates (and perhaps altered glass fragments).

The echinoderm(?) plates are brown, soft, sectile, waxy, and montmorillonitic. The altered glass fragments near the basalt are of two types. Small angular to subrounded ones are waxy montmorillonite in various shades of brown. Larger, subangular to subrounded clasts (up to $3 \mathrm{~mm}$ diameter) are light tan, soft, calcitic, and look much like fragments of layer (5). Like layer (5), these large light tan clasts rarely contain red palagonite like that of layer (4). They tend to confirm that the sediment is hyaloclastic, and that it was probably formed and considerably stirred during emplacement of the overlying basalt. They are concentrated in layer (6a). Similar, but somewhat lighter, grayer, calcite-richer granules in layer (6c) may be of an origin similar to that of the light tan clasts, or they may be limestone fragments. Layer (6a) contains rare amygdule-like montmorillonite ovoids of uncertain origin. They may be amygdules in glass clasts whose outlines are no longer recognizable. In layers (6a) and (6b) there are irregular, black or dark gray, soft, brittle, coal-like patches. The largest one is $5 \times 2.5 \mathrm{~mm}$. It has a brecciated outer zone cemented by light gray calcite. It either breaks conchoidally or smears as if sectile, and has a dark reddish brown streak. X-ray analysis (Appendix A) indicates well-crystallized goethite, a trace of chabazite, and a very uncertain trace of chlorite. The patch may be sideromelane in an intermediate state of alteration or an altered plant fragment.

Along one side of the core, transecting all of the sediment layers and abutting layer (5) of the basalt, is a subangular, partly joint-bounded, medium yellowish brown, finely variolitic basalt clast at least $65 \times 17 \times 8 \mathrm{~mm}$ in size. The texture and the presence of apparent altered interstitial glass in what is evidently a chilled selvage suggest a fragment from near the surface of a flow. Plagioclase and rare altered olivine(?) microphenocrysts are visible but not prominent. The straight joint-bounded edge may be a primary shrinkage crack along which chilled, highly glassy layers spalled off. Large (5 to $7 \mathrm{~mm}$ ) and small calcite patches appear to be of replacement origin rather than amygdules. Vesicles lined or filled with montmorillonite comprise less than $0.5 \%$ of the clast.

The clast is microporphyritic, but it certainly does not match in size or abundance the microphenocrysts of olivine and plagioclase and the phenocrysts and glomerocrysts of olivine in the overlying pillowed basalt. One $4 \times 3 \mathrm{~mm}$, light reddish brown object in the clast may be an altered phenocryst, xenocryst or xenolith. A xenolith would suggest autobrecciation during emplacement.

Immediately below the sideromelane of layer 3 is a patch of sparry calcite (3.5 mole \% $\mathrm{MgCO}_{3}$; Appendix A and Table 6) which is a continuation of the similarly situated sparry calcite in 17-171-27-3, 92-104 cm.

17-171-33-CC: Specimen is a medium brownish gray, finegrained porphyritic olivine basalt, with a distinct reddish tinge. The only phenocrysts are olivine (pseudomorphs). Plagioclase occurs exclusively as laths which outline a swirly flow structure; locally the laths are subparallel and define a distinct intersertal trachy toid flow structure. The rock contains montmorillonite amygdules up to $8 \times$ $3 \mathrm{~mm}$, but commonly much smaller. The larger ones enclose patches of calcite. Numerous calcite veins $\left(3.0\right.$ mole $\left.\% \mathrm{MgCO}_{3}\right)$ cut the rock, and in some cases cut the montmorillonite ovoids, showing that vein deposition was later than amygdule formation. Light reddish brown selvages and short vein segments are composed of Na-saturated montmorillonite and a very uncertain trace of chlorite (Appendix A).

This rock is definitely chilled, but the outermost selvage is not present. It is distinctly different from the pillow lavas higher in the section, and this difference is confirmed chemically in the higher trace element contents and higher $\mathrm{TiO}_{2}$ in 17-171-33-CC (Table 1). $\mathrm{The} \mathrm{TiO}_{2}$ is reflected mineralogically as abundant ilmenite, the most abundant in any igneous rock from Leg 17.

The present opaque mineral assemblage (maghemite and ilmenite; Appendix A and Table 5) indicates an original assemblage of ilmenite plus any one of Ti-poor titanomagnetite, pure magnetite, or maghemo-magnetite. This original assemblage indicates highly oxidizing conditions, which is consistent with the late oxidation to iddingsite of the outer edges and cracks in olivine. Chlorite, seen in the total rock X-ray pattern (Appendix A), may have formed at the same time as iddingsite or by later hydrothermal metamorphism. Arguments were presented above in favor of later hydrothermal metamorphism.

In the mode below there is uncertainty in the assignment of montmorillonite to components 1, 6 and 7. In particular, olivine microphenocrysts and especially groundmass olivine may be somewhat exaggerated at the expense of groundmass montmorillonite. 


\begin{tabular}{lcc}
\hline \multicolumn{1}{c}{$\begin{array}{c}\text { Component } \\
(\mathrm{min} / \mathrm{max} \text { size }-\mathrm{mm})\end{array}$} & $\begin{array}{c}\text { Average } \\
\text { Size }(\mathrm{mm})\end{array}$ & $\begin{array}{c}\text { Volume } \\
(\%)\end{array}$ \\
\hline $\begin{array}{l}\text { Olivine microphenocrysts } \\
(\text { Pseudomorphs })^{\mathrm{a}}\end{array}$ & $0.6 \times 0.45$ & 9.8 \\
$(0.2 \times 0.15 / 1.1 \times 0.7)$ & & \\
$\begin{array}{l}\text { Plagioclase } \\
(0.15 \times 0.01 / 0.35 \times 0.03)\end{array}$ & $0.25 \times 0.03$ & 29.5 \\
$\begin{array}{l}\text { Opaque inclusions in olivine } \\
(0.007 \times 0.007 / 0.04 \times 0.04)\end{array}$ & $0.025 \times 0.025$ & 0.1 \\
$\begin{array}{l}\text { Opaque grains } \mathrm{c} \\
(0.04 \times 0.002 / 0.5 \times 0.03)\end{array}$ & $0.1 \times 0.01$ & 13.6 \\
$\begin{array}{l}\text { Pyroxene } \\
(0.02 \times 0.02 / 0.25 \times 0.2)\end{array}$ & $0.08 \times 0.05$ & 10.4 \\
$\begin{array}{l}\text { Montmorillonite }(\text { groundmass })^{\mathrm{e}} \\
\text { Groundmass olivine } \\
\quad(\text { Pseudomorphs) }\end{array}$ & & \\
$(0.04 \times 0.03 / 0.1 \times 0.1)$ & $0.05 \times 0.04$ & 11.9 \\
Chlorite & & \\
\hline
\end{tabular}

\footnotetext{
a Light grayish brown montmorillonite pseudomorphs, often glomeratic, with orange brown iddingsite along rims and cracks (Plate 6, Figure 3).
}

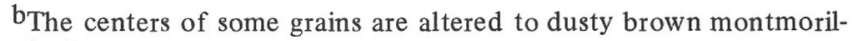
lonite.

cSkeletal platy grains.

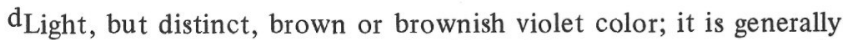
intergranular, uncommonly subophitic. Most pyroxene was probably altered to montmorillonite, but direct evidence of this is lacking.

e Light grayish brown, intersertal montmorillonite, identical to the montmorillonite of the pseudomorphs after olivine and thus rendering it difficult to infer accurately the former edges of olivine grains (components 1 and 7).

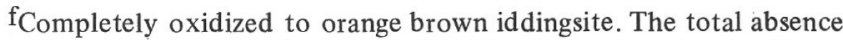
of pseudomorphs of montmorillonite after groundmass olivine without an iddingsite core or rim indicates that the highly oxidizing conditions that led to formation of iddingsite were late, and not a temporary condition of the magma that was reversed before the crystallization of olivine ceased.

gDefinitely identified only in the total rock X-ray pattern (Appen$\operatorname{dix} \mathrm{A}$ ); it may constitute rare green rims seen on pyroxene. In this relatively fine-grained, rapidly cooled rock the chlorite is unlikely to be deuteric, and poses evidence for a post-magmatic period of hydrothermal metamorphism, as concluded even more strongly from 17-171-27-1, 133-142 cm, where traces of chlorite occur in amygdules in the glassy selvage of the pillow. 